\title{
CHEMICAL TECHNOLOGY BRANCH ANNUAL REPORT FISCAL YEAR 1967
}

\author{
J. R. Bower, Editor
}

\section{IDAHO NUCLEAR CORPORATION NATIONAL REACTOR TESTING STATION IDAHO FALLS, IDAHO}




\section{DISCLAIMER}

This report was prepared as an account of work sponsored by an agency of the United States Government. Neither the United States Government nor any agency Thereof, nor any of their employees, makes any warranty, express or implied, or assumes any legal liability or responsibility for the accuracy, completeness, or usefulness of any information, apparatus, product, or process disclosed, or represents that its use would not infringe privately owned rights. Reference herein to any specific commercial product, process, or service by trade name, trademark, manufacturer, or otherwise does not necessarily constitute or imply its endorsement, recommendation, or favoring by the United States Government or any agency thereof. The views and opinions of authors expressed herein do not necessarily state or reflect those of the United States Government or any agency thereof. 


\section{DISCLAIMER}

Portions of this document may be illegible in electronic image products. Images are produced from the best available original document. 
Printed in the United States of America

Available from

Clearinghouse for Federal Scientific and Technical Information

National Bureau of Standards, U. S. Department of Commerce

Springfield, Virginia 22151

Price: Printed Copy $\$ 3.00$; Microfiche $\$ 0.65$

\section{LEGAL NOTICE}

This report was prepared as an account of Government sponsored work. Neither the United States, nor the Commission, nor any person acting on behalf of the Commission:

A. Makes any warranty or representation, express or implied, with respect to the accuracy, completeness, or usefulness of the information contained in this report, or that the ure of any information, apparatus, method, or process disclosed in this report may not infringe privately owned rights; or

B. Assumes any liabilities with respect to the use of, or for damages resulting from the use of any information, apparatus, method, or process disclosed in this report.

As used in the above, "person acting on behalf of the Commission" includes any employee or contractor of the Commission, or employee of such contractor, to the extent that such employee or contractor of the Commission, or employee of such contractor prepares, disseminates, or provides access to, any information pursuant to his employment or contract with the Commission, or his employment with such contractor. 


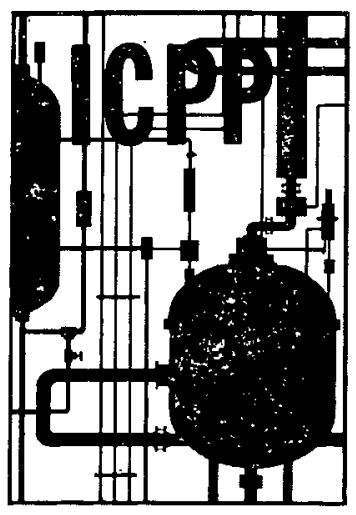

IN -1087

Issued: October 1967

General, Miscellaneous, and progress Reports

TID -4500

CHEMICAL TECHNOLOGY BRANCH ANNUAL REPORT

FISCAL YEAR 1967

D. R. de Boisblanc

MANAGER

NUCLEAR AND CHEMICAL TECHNOLOGY DIVISION

J. A. Buckham

MANAGER

J. R. Bower EDITOR

CHEMICAL TECHNOLOGY BRANCH

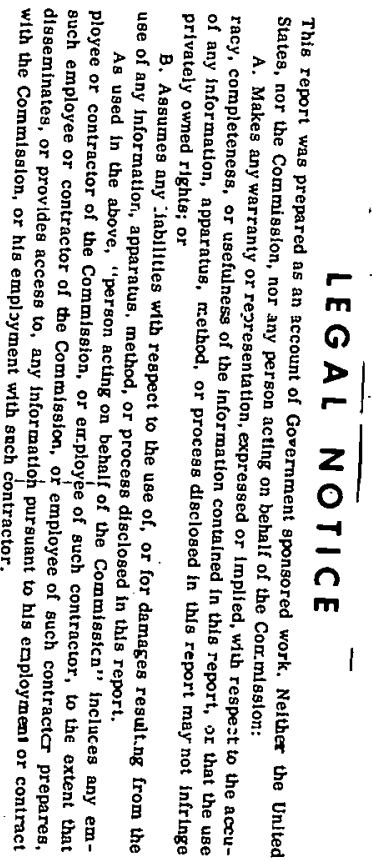

U. S. Atomic Energy Commission Research and Development Report

Issued Under Contract AT(10-1)-1230

Idaho Operations Office 


\section{SUMMARY}

The principal ICPP fuel dissolution processes were maintained in standby during this period while the Waste Calcining Facility was in full-time operation. As schedules permitted, however, small lots of fuels which required separate accountability or which were expected to be unusually difficult to dissolve were processed through batch dissolution equipment. In addition, the fuel from Core 2 of Experimental Breeder Reactor I (EBR-I), which had undergone partial meltdown in the reactor, was successfully recovered in small-scale equipment operated under direct visual control in a heavily shielded cell. Similarly, uranium was readlly recovered from broken Vycor glass molds used for casting EBR-II fuel pins.

Process support studies indicated that silicon in aluminum-uranium-silicon alloys had no adverse effect on dissolution of the alloys; on the other hand, copper in aluminum, as in alloy 2219 , seriously reduced the dissolution rate in mercurycatalyzed nitric acid. Corrosion observations during zirconium fuel processing indicated generally favorablè experience under properly controlled conditions but very rapid corrosion with improperly chosen materials or conditions of operation. Criticality review of the ICPP partially reflected $71 / 2$-inch-diameter continuous dissolvers showed them to be safe for any possible loading and configuration of disintegrated fuel (or meat) from the new ETR fuel elements (505 g U-235, 93 percent enriched).

A combustion-dissolution process for graphite fuels, based on a two-stage fluidized bed burner for combustion of the graphite and a continuous elutriation process for removal of metal oxide products from the operating fluidized bed, has performed satisfactorily in initial tests of a newly installed pilot plant. Uranium buildup on the bed can be controlled, separation of the oxide products without carryover of bed material appears to be satisfactory, and up to 97.5 percent of the graphite from Kover fuel elements has been burned off. Several common alloys have proved satisfactory as materials of construction for the burner. Uranium is readily dissolved from the elutriated burner ash by nitric acid treatment.

An electrolytic dissolver pilot unit for studying dissolution characteristics of EBR-II fuel (enriched uranium alloy core, bonded with sodium, and clad in stainless steel) has been designed and is being installed. A two-step dissolution process for Zircaloy-4-clad $\mathrm{ZrO}_{2}-\mathrm{UO}_{2}$ fuels, a possible alternate to a threestep aqueous process or a halide volatility process, produces a solution suitable for solvent extraction by dissolving the cladding in $10 \mathrm{M} \mathrm{HF}$, dissolving the oxide core in fused ammonium bifluoride, and combining all in a solution complexed with aluminum nitrate.

The Waste Calcining Facility operated throughout the period, oonverting approximately 595,000 gallons of first cycle aqueous waste to 6600 cublc feet of solids in 15 months of the second operating campaign. (Since initial operation in 1963, about $1,100,000$ gallons of highly radioactive wastes have been reduced to sollds.) Though some unscheduled shutdowns have occurred, general operation of the facility continues to be excellent. Metallurgical changes in portions of the Type 316 stainless steel $\mathrm{NaK}$ heat exchange system, as a result of over 19,000 hours service at or above $600^{\circ} \mathrm{C}$, have contributed to the principal temporary shutdowns of the system. 
Pilot plant calcination: of zirconium-hydrofluoric acid wastes, complexed with calcium nitrate, was successfully demonstrated in a 212 -hour run at $400^{\circ} \mathrm{C}$ and a $\mathrm{Ca} / \mathrm{F}$ mole ratio of 0.55 . A process for heating the fluidized bed calciner by in-bed combustion of a hydrocarbon fuel has been demonstrated by burning kerosene in the bed of a 12-inch-diamter pilot plant calciner to calcine nitratecontaining wastes at $438^{\circ} \mathrm{C}$; a significant increase in energy input, and a corresponding increase in calcining capacity, appears to be possible as compared with the existing heating system. Additional pilot plant studies indicate (a) that dolomite is superior to sand as a calciner startup bed (if nonradioactive calcined alumina is not avallable); (b) that a vortex restrictor, using air as the controlling medium, may be a useful substitute for a valve for feed control to the calciner; and (c) that the WCF scrubbing system should satisfactorily withstand the corrosion-erosion characteristics of acidic zirconia-containing solutions present while calcining zirconium fuel wastes. An improved computational algorithm has been developed for the mathematical model describing the transient particle size distribution within the fluidized bed calciner.

Heat transfer studies, during calcination in a fluidized bed pilot unit, have dəmonstrated that heat transfer rates from multiple horizontal tubes to fluidized beds can be predicted by a dimensionless correlation of easily defined terms. Further, the heat transfer rates can be increased many-fold by use of finned surfaces in place of bare tubes. Heat transfer within storage facilities has been studied from the standpoints of: (a) heat dissipation from buried radioactive sources; (b) heat transfer across vertical cylindrical air gaps; and (c) effects of fission product migration on temperatures within a mass of calcine stored under conditions permitting the centerline temperatures to approach the fusion temperature of alumina $\left(2000^{\circ} \mathrm{C}\right)$.

Additional waste management studies reported include (a) the volatility of minor constituents from calcined waste stored at up to $800^{\circ} \mathrm{C}$; (b) the corrosive effects of zirconia calcine in storage; (c) the removal and recovery of mercury from WCF feed; and (d) a computer program for blending ICPP wastes to give maximum permissible heat generation rates in the existing calcine storage bins.

Continuing LOFT assistance studies have indicated a number of reactor containment shell coatings that are resistant to LOFT experimental conditions; embedding woven glass fabric in the coatings makes them resistant to cracking when applied over expansion joints in concrete. Four possible methods for decontaminating coating systems are described. Penetration of iodine into coatings, probably the most troublesome aspect of fission product contamination, has been described on a mathematical basis, permitting the scaleup of plateout data on protective coatings from laboratory experiments to pilot plant scale vessels. The Contamination-Decontamination Experiment (CDE), an experimental unit for releasing fission products from melted irradiatedfuel specimens into a confined, controlled-atmosphere test chamber, has performed efficiently in four separate high-activity runs to provide the environment for testing protective coatings, sampling systems, fission product behavior, and decontamination techniques. Tests of a continuous sampler-monitor for sampling the containment atmosphere during the LOFT experiments, indicate its effectiveness for removing inorganic iodine vapors and particulates larger than 0.1 micron; smaller particulates and organic iodides are trapped much less effectively. Tests in conjunction with CDE Run 3 provided revealing information regarding the nature and action of particulates and iodine during and after a fuel pin meltdown. Fission product 
plateout sample capsules have operated successfully in the two latest CDE tests and the results are discussed to show the effects of coupon orientation, structural shielding, temperature and condensation, and sampler location on the particulate contamination collected. Examination of residues from fuel pin meltdown in the $\mathrm{CDE}$ disclosed formation of a physically stable shell of $\mathrm{ZrO}_{2}$ where the Zircaloy clad fuel pin was exposed to the steam atmosphere, although the uranium core and cladding area shielded from steam were completely melted. A report has been issued giving values for physical properties of $\mathrm{UO}_{2}, \mathrm{ZrO}_{2}$, and $\mathrm{Zircaloy}-4$ in temperature ranges most usable for the analysis of a loss-of-coolant accident.

Other reactor technology support programs include development of a method for producing uranium aluminide $\left(\mathrm{UAl}_{3}\right)$ in a fluidized bed reactor using uranyl nitrate and aluminum as starting materials; no metallic uranium is handled anywhere in the process and the product leaves the process in its desired size and shape. Removal of boehmite from aluminum fuel element surfaces, leaving a passive surface, has been accomplished by treatment in boiling $1.0 \mathrm{M}$ phosphoric acid - $0.4 \underline{\mathrm{M}}$ chromium trloxide solution, followed by film removal in $3 \mathrm{M}$ nitric acid.

Pilot Plant laboratories, designed to accommodate modular units, are being put into operation at the ICPP. The modular concept permits broad flexibility, rapid installation and interchange of equipment, minimum interference of construction with experimental activity, and generally high efficiency in use of space, material, and manpower. 


\section{CONTENTS}

SUMMARY...........................

I. FUEL REPROCESSING. . . . . . . . . . . . . . . . 1

1. PERFORMANCE OF ICPP FUEL RECOVERY PROCESSES . . . . . 1

1.1 Aluminum Fuel Reprocessing .................. 1

1.2 Recovery of Uranium from EBR-I Core 2 Melt . . . . . . . . . . 3

1.3 Recovery of Uranlum from EBR-II Vycor Glass Molds . . . . . . . 3

1.4 ICPP Modifications ................... 4

2. SUPPORT STUDIES FOR CURRENT ICPP FUEL RECOVERY

PROCESSES.......................... 7

2.1 Dissolution of Aluminum-Uranfum-Stilenn Alloys ... . . . . 7

2.2 Dissolution of Aluminum Alloy 2219 . . . . . . . . . . 10

2.3 Corrosion Observations During Zirconium Fuel

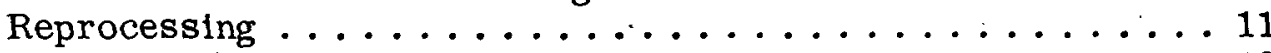

2.4 Nuclear Safety in the ICPP Dissolvers . . . . . . . . . . 13

3. GRAPHITE FUELS REPROCESSING. . . . . . . . . . . . 15

3.1 P1lot Plant Studies of the Fluidized Bed Combustion-Nitric

Acld Dissolution Process .................. 16

3.2 Corrosion Observations in the Graphite Burner . . . . . . . 20

3.3 Leaching of Uranium from Burner Ash . . . . . . . . . . . . 20

4. SUPPORT STUDIES FOR OTHER SCHEDULED ICPP PROCESSING

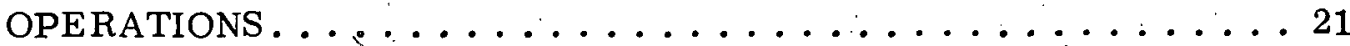

4.1 Electrolytic Dissolution Studies . . . . . . . . . . . . 21

4.2 Ammonlum Bifluoride Process for Zirconium Clad Zirconium

Dioxide-Uranium Dioxide Fuels . . . . . . . . . . . 25

4.3 Chemical Destruction of Dowex Resin . . . . . . . . . . 30

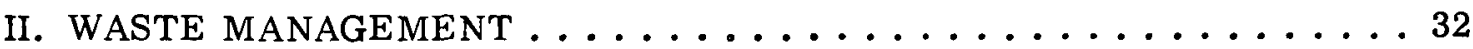

1. THE IDAHO WASTE CALCINING FACILITY $\ldots \ldots \ldots \ldots \ldots$

1.1 Operating Experience in the Current WCF Processing

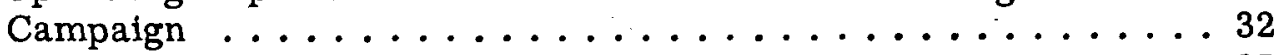

1.2 NaK Heating Problems in the Current WCF Campaign . . . . . 35

1.3 Effect of NaK on Stainless Steel PIping in the WCF Heat

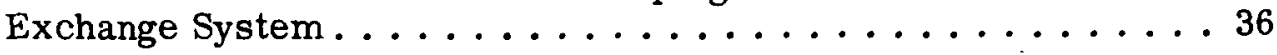

2. ADVANCED WASTE CALCINATION STUdIES . . . . . . . . 42

2.1 Pilot Plant Calcination of Zircontum-Hydrofluoric Actd

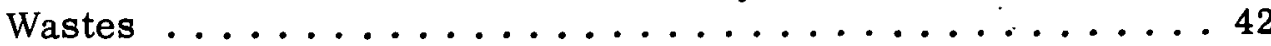

2.2 Fluidized Bed Calcination Using In-Bed Combustion of Fuel . . 45 
2.3 Startup Beds for the WCF . . . . . . . . . . . . . . . . 47

2.4 Valveless Feed Control for the WCF . . . . . . . . . . . . 48

2.5 Corrosion-Erosion Testing of Materials Used in WCF Con-

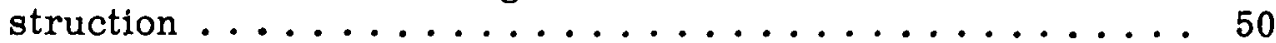

2.6 Model for Transient Particle Size Diśtribution in Fluidized Bed Calciner ..................... 53

3. PROPERTIES OF SOLID CALCINED WASTE . . . . . . . . . . 55

3.1 Volatility of Minor Constituents from Calcine ......... 55

3.2 Corrosive Effects of Zirconia Calcine in Storage . . . . . . 57

4. HE AT TRANSFER STUDIES AFFECTING THE CALCINATION PROCESS AND STORAGE OF THE CALCINED PRODÚCT . . . . . 57

4.1 Heat Transfer from Horizontal Tuhe Bundles to Fluldized Beds of Solids . . . . . . . . . . . . . . . . . 57

4.2 Transfer of Heat from Fluned Tubes to a Fluidized Bed . . . . . 61

4.3 Heat Dissipation from Buried Radioactive Sources . . . . . . . 62

4.4 Storage of Calcine at Elevated Temperatures . . . . . . . . . 66

4.5 Heat Transfer Across Vertical Cyclindrical Air Gaps . . . . . 69

5. ADDITIONAL WASTE MANAGEMENT STUDIES . . . . . . . . 71

5.1 Removal and Recovery of Mercury from WCF Feed ...... 71

5.2 Waste Blending Study ................... 72

III. REACTOR TECHNOLOGY SUPPORT ............... 73

1. LOFT ASSISTANCE PROGRAM ................ 73

1.1 LOFT Coating and Elastomer Evaluation and Decontamination

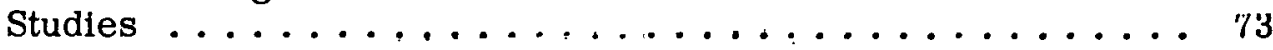

1.2 The Penetration of Iodine Into Protective Coatings . . . . . . 81

1.3 Contamination-Decontamination Fxperiment .........

1.4 Continuous Sampler-Monitor for the Contalnment Building

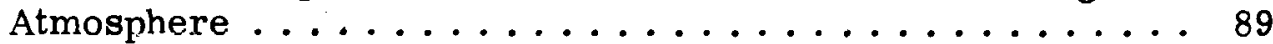

$i \quad 1.5$ Fission Product Sorption on Materials of Construction for

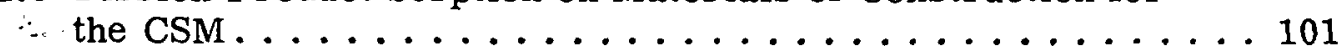

1.6 Evaluation of LOFT Plateout Capsulcs ............. 103

1.7 Studies of Unirradiated Fuel Pin Meltdown Residues . . . . . . 108

1.8 High Temperature Properties of Materials ............ 111

2. OTHER REACTOR TECHNOLOGY SUPPORT PROGRAMS . . . . 112

2.1 A new process for Uranium Aluminide Manufacture Employing Fluidfzed Bed Techniques . . . . . . . . . . . . . 112

2.2 Removal of Boehmite Coating from Al'R Fuel Elements . . . . 116

IV. NEW MODULAR PILOT PLANT LABORATORIES . . . . . . . . . 119

1. THE HIGH-BAY LABORATORY . . . . . . . . . . . . 120

2. THE LOW-BAY LABORATORY . . . . . . . . . . . . . 120 
3. ADVANTAGES OF THE MODULAR PLAN . . . . . . . . . 121

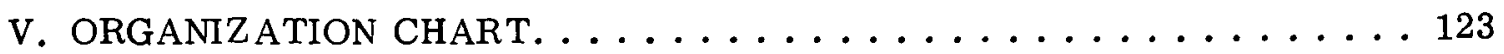

VI. REFERENCES . . . . . . . . . . . . . . . . . . . . . . . 124

VII. REPORTS AND PUBLICATIONS ISSUED DURING FY $1967 \ldots \ldots$. . . . 127

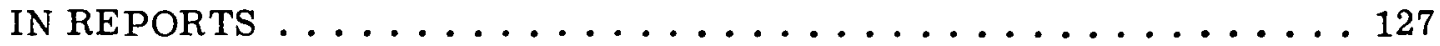

PAPERS PRESENTED AT TECHNICAL SOCIETY MEETING. . . . . . 128

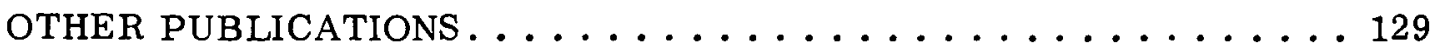

FIGURES

1. Comparison of aluminum and uranium dissolution in aluminumuranium-silicon alloys ..................... 9

2. Keff curve for ICPP continuous dissolver containing ETR fuel element meat $[28$ percent $U(93$ percent 235$)]$ and water $\ldots \ldots \ldots \ldots$

3. Combustion-dissolution process for graphite fuels . . . . . . . . . 15

4. Uranium buildup in the fluidized bed during combustion of uraniumgraphite fuels.......................... 17

5. Graphite fuels pilot plant equipment flow diagram . . . . . . . . 18

6. Electrolytic dissolver ..................... 23

7. Flow sheet of electrolytic dissolution system . . . . . . . . . . 24

8. Flow sheet for two-step aqueous-fused salt dissolution of advanced

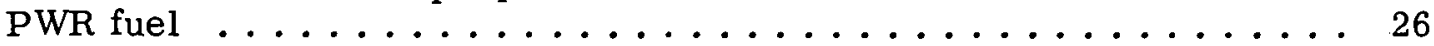

9. Solubility of uranium in anhydrous $\mathrm{NH}_{4} \mathrm{HF}_{2}$ versus temperature . . . 28

10. Solubility of zirconlum in anhydrous $\mathrm{NH}_{4} \mathrm{HF}_{2}$ versus temperature . . . 29

11. Sigma particle in X-Section of 3 -inch Schedule 40 Type 316 SS pipe

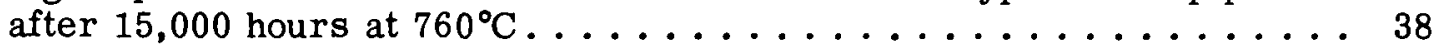

12. Cross section of 3 -inch Schedule 40 Type 316 SS pipe after 15,000

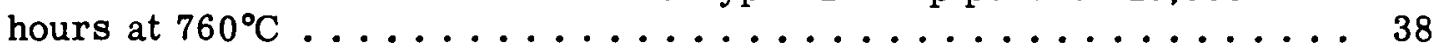

13. Decarburized zone of inside edge of 3-1nch Schedule 40 Tyje 316 SE pipe after 15,000 hours at $760^{\circ} \mathrm{C} \ldots \ldots \ldots \ldots . \ldots \ldots$

14. Outside, or air side, of 3 -inch Schedule 40 Type 316 SS pipe after

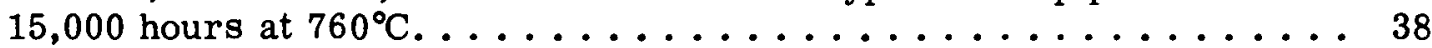

15. Crack on inside of pipe tee connector after 15,800 hours at 600 to

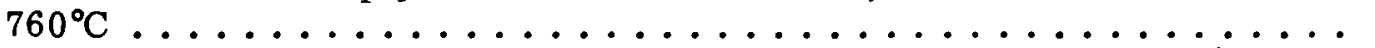


16. NaK expansion tank weld fallure after 3,240 hours at 600 to

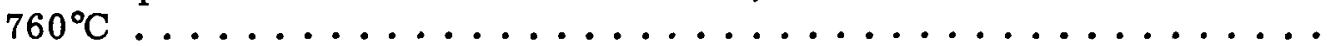

17. Surfáce topography of nozzle-connector weld failure after 3,240 hours at 600 to $760^{\circ} \mathrm{C}$, showing crack front arrest lines . . . . . . .

18. Surface topography of weld fallure after 15,800 hours at 600 to $760^{\circ} \mathrm{C}$, showing uniformly distributed faceted particles ........... 41

19. Four-inch-diameter calciner .................. 46

20. Simplified flow sheet of in-bed combustion calciner system . . . . . 46

21. Cut-away view of vortex restrictor .............. 49

22. Schematic diagram of apparatus for testing vortex reotrictor operation. ......................... 4 ...

23. Vortex restrictor performance curve ................ . 50

24. Schematic diagram of corrosion-erosion test loop ......... 51

25. Correlation of heat transfer data from in-bed heat exchangers . . . . 59

26. Calculated transient temperatures in a buried cylindrical bin filled with solidified waste ...................... 65

27. Calculated transient temperatures in a buried cylindrical bin filled with unsolidified waste

28. Effective thermal conductivities across annular spaces as a function of the Rayleigh number . . . . . . . . . . . . . . . 71

29. Effect of pressurized steam on coatings with and without woven glass fabric applied over a silicone rubber elastomer . . . . . . . 76

30. Enlarged view of an expansion joint and coating system in the LOFT

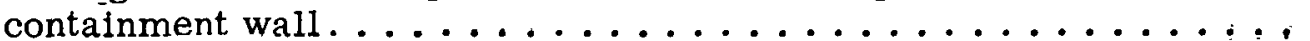

31. Schematic flow sheet of the Contamination-Decontamination

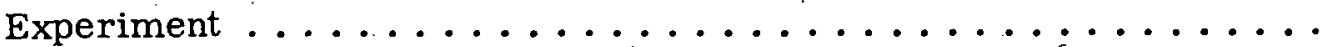

32. Furnace assembly system as modified for CDE Run $4 \ldots \ldots \ldots$. . . . 83

33. Suhematı flów sheet of Continuous Sampler-Monitor . . . . . . . . 90

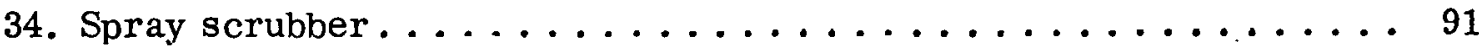

35. Schematic flow sheet of apparatus for fluorescein dust scrubbing

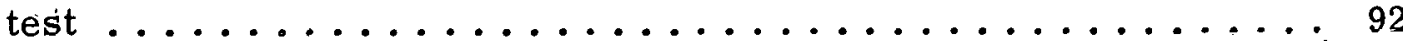

36. Particle size distribution of fluorescein dust . . . . . . . . . 93 
37. Impaction efficiencies of spherical collectors $\ldots \ldots \ldots \ldots \ldots \ldots$

38. Schematic flow sheet of apparatus for the methyl lodide scrubbing

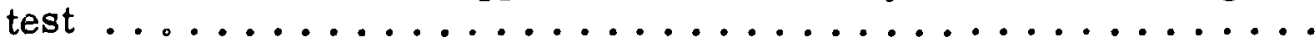

39. CSM schematic flow sheet for CDE Run $3 \ldots \ldots \ldots \ldots . \ldots 98$

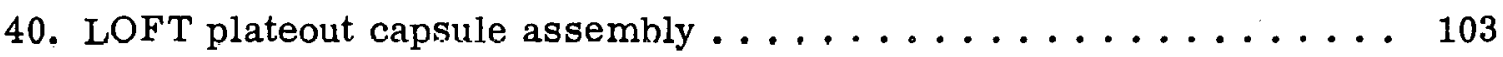

41. Capsule support rack for CDE containment vessel . . . . . . . 104

42. Controlled-temperature sampler . . . . . . . . . . . . . . 109

43. Effect of temperature and condensation on fission product deposition .......................... 109

44. $\mathrm{CDE}$ induction furnace showing fuel pin in center of induction coll . . 110

45. Schematic flow sheet of apparatus for fluidized bed production of

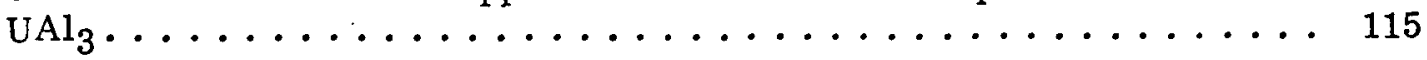

46. Experimental module being lifted outside of high-bay laboratory . . . 121

47. Experimental module over open roof hatch of high-bay laboratory . . 121

48. Experimental module being lowered into high-bay laboratory . . . . 122

49. Two experimental modules in place in high-bay laboratory . . . . . 122

\section{TABLES}

I. Aluminum Allnyed Fuels Processed During Fiscal Year 1967

II. Instantaneous Dissolution Rates for Alumlnum-Uranium-Silicon Alloys . . . . . . . . . . . . . . . . .

III. Dissolution Rates for Type 2219 Aluminum in $6.0 \mathrm{M} \mathrm{HNO}_{3}$

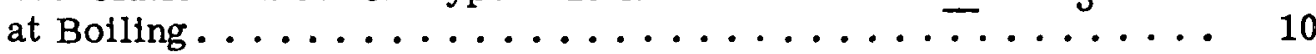

IV. Vapor Phase Corrosion of Type 304L Stainless Steel Containing $1.5 \%$ Boron . . . . . . . . . . . . . . . .

V. Corrosion of Titanium in Synthetic Zirconfum Processing Solutions at $35^{\circ} \mathrm{C} \ldots \ldots \ldots \ldots \ldots \ldots \ldots \ldots$

VI: Corrosion of Various Alloys after 73 Hours in the Graphtte Fuel Burner . . . . . . . . . . . . . . . .

VII. Composition of the Atmosphere in the Graphite Fuel Burner ... 
VIII. Corrosion Rates for Various Metals in Fused Ammonium

Bifluoride ........................ 30

IX. Test Conditions and Results During Trial Dissolution of

Dowex 1-X4 Resin . . . . . . . . . . . . . . . . 31

X. Waste Calcining Facility Operating Summary _- Run H-2 . . . . 32

XI. Corrosion of Wrought Type 316 Stainless Steel Pipe in Boiling 65 Percent Nitric Acid after 16,292 Hours Service in NaK at

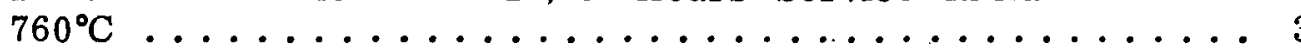

XII. Mechanical Properties of Type 316 Stainless Steel Before and After Exposure to High Temperature NaK . . . . . . . . . . . 39

XIII. Average Feed Composition of Simulated Zirconium Waste . . . . 43

XIV. Operating Conditions for Pilot Plant Caloination of Zircontum

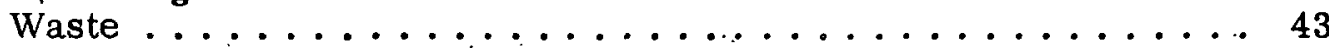

XV. Steady State Values of Experimental Parameters . . . . . . . . 44

XVI. Chemical Composition of Calcined Solids . . . . . . . . . . . 44

XVII. Chemical Composition of Scrubbing Solution . . . . . . . . 45

XVIII. Comparison 'of WCF and Test Operating Conditions . . . . . . 52

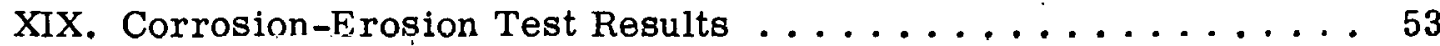

XX. Volat1lity of Minor Constituents From WCF Calcine During Long-Term Heating . . . . . . . . . . . . . . 56

XXI. Cryslallnily of Wi: Alumina Calotno During Long=Terin Heating ......................... 50

XXII. Summary of Fluidized Bed Heat Transfer Data . . . . . . . . . 58

XXIII. Minimum Fluidization Mass Flow Rates . . . . . . . . . . 60

XXIV. Heat Balance at the Surface of the Heated Cylinder . . . . . . . 70

XXV. Resistance of Coatings to Decontaminants and Environmental Conditions Present During the LOFT experiment . . . . . . . . 74

XXVI. Effect of Primers on Coating Systems Subjected to Conditions Present During the LOFT Experiment . . . . . . . . . . 77

XXVII. Contamination-Decontamination Behavior of Materials Contaminated in CDE Run $2 \ldots \ldots \ldots \ldots \ldots$

XXVIII. Comparison of Operating Conditions for CDE Runs 3 and $4 \ldots \ldots$. . 85

XXIX. Fission Products Released from Fuel . . . . . . . . . . . 86 
XXX. Fission Product and Material Accountability . . . . . . . . 87

XXXI. Distribution of Fission Products Transported from the Furnace

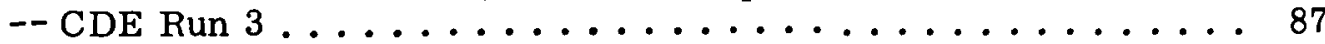

XXXII. Composition of Particulates Released from CDE Fuel . . . . . 88

XXXIII. Impaction Efficiencies of Spray Drops $\ldots \ldots \ldots \ldots$

XXXIV. Relative Distribution of Iodine-131 in the Scrubber-Filter

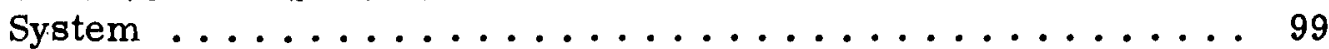

XXXV. Percent of Iodine-131 Inventory Airborne in Containment . . . . 100

XXXVI. Relative Distribution of Iodine-131 Throughout System, Including Line Plateout. . . . . . . . . . . . . . 100

XXXVII. Total Activity on Coupons Tested for Fission Product Sorption . . 102

XXXVIII. Comparison of Fission Product Deposition on Capsule Coupons . . 105

XXXIX. Comparison of Fission Product Deposition on Coupons Inside and Outside of Capsules for CDE Run 3 and $4 \ldots \ldots . . \ldots 106$

XL. Effect of Coupon Orientation on Fission Product Deposition for CDE $\operatorname{Run} 4 \ldots \ldots \ldots \ldots . \ldots \ldots 10 . \ldots \ldots$

XLI. Effect of Orientation on Fission Product Deposition on Controlled Temperature Coupons for CDE Runs 2 and 3. . . . . . . . 108

XLII. Properties of Uranium-Aluminides .............. 112

XLIII. Test Reactor Fuel Cycle.................... 116

XLIV. Corrosion of Type 6061-0 Aluminum by Phosphortc AcidChromium Trioxide Solution . . . . . . . . . . . . 117

XLV. Phosphorus Content of F1lm Deposited on 6061-0 Aluminum . . . 117

XLVI. Corrosion of Type 6061-0 Aluminum by Bolling 3M Nitric

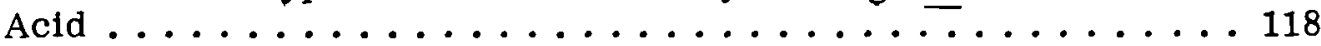




\section{I, FUEL REPROCESSING}

\section{PERFORMANCE OF ICPP FUEL RECOVERY PROCESSES}

1.1. Aluminum Fuel Reprocessing

(R. E. Commander; Production Engineering)

1.11 Summary of Operations. The main ICPP fuel dissolution processes were not in operation during this period due to limited fuel inventories in storage and the scheduling of the Waste Calcining Facility for full time operation. Advantage was taken of this situation to decontaminate the main processing plant and make desirable modifications (Section I-1.4). However, several small lots of uranium-aluminum alloy fuels which required separate accountability or which were expected to present unusual difficulty in dissolution were processed through the batch dissolution equipment as manpower permitted. Following batch dissolution, the fuels were blended as appropriate and the uranium was recovered and decontaminated by three cycles of Hexone extraction.

1.12 Fuel Dissolution. The batch process equipment in D' Cell was used for the part time dissolution and feed adjustment of several aluminum alloy fuels (JRR-2, NRU, and NRX), during the period from March 16, 1967 to May 24, 1967. The amount of uranium processed in each type of fuel is shown in Table $I$.

\section{TABLE I}

ALUMINUM ALLOYED FUELS PROCESSED DURING FISCAL YEAR 1967

\begin{tabular}{lccc}
\hline Fuel Type & $\begin{array}{c}\text { Number of } \\
\text { Elements Dissolved }\end{array}$ & $\begin{array}{c}\text { Total } \\
\text { Charged } \\
(\mathrm{kg})\end{array}$ & $\begin{array}{c}\text { U-235 } \\
\text { Charged } \\
(\mathrm{kg})\end{array}$ \\
\cline { 2 - 2 } & 24 & $\frac{21.53}{4.25}$ & 3.32 \\
NRX & $60[\mathrm{a}]$ & 4.12 & 2.43 \\
NRU & 52 & 3.10 & \\
[a] This number included forty-five (45) 27-inch elements and fifteen \\
(15) 8-inch elements.
\end{tabular}

The fuels processed were dissolved with a solution of nitric acid, water, and mercuric nitrate catalyst. For all fuels the acid concentration of the dissolving solution was $5.5 \mathrm{M}$; the catalyst concentration was set at $0.01 \mathrm{M}$ for the JRR-2 fuel and at $0.05 \mathrm{M}$ for the Chalk River fuels.

The dissolver product was transferred to the coarse feed adjustment tank where it was sampled for uranium input and adjusted to $0.26 \pm 0.10 \mathrm{M}$ acid deficient (allowing for the calculated final volume after bolldown) by the addition of $\mathrm{NH}_{4} \mathrm{OH}$. The feed solution was then boiled down in the fine feed tank to obtain the proper specific gravity and acid deficiency for processing in the Hexone extraction system. 
The dissolution of the JRR-2 fuel was quite similar to that of MTR-type fuel, and no major problems were encountered. Confirming previous experience, the Chalk River fuels (NRX and NRU) dissolved more slowly and revisions in the dissolution procedure were made during the processing to correct some of the problems. For both the NRX and NRU fuels, the volume of dissolving solution required for each batch was greater than the volume of the dissolver. Because of this, the dissolution of each batch was done in two parts, with the dissolvent being added in two separate increments. It was found that dissolution of the first part of each batch proceeded quite readily (10 hours exposure), but the dissolution of the second portion was very slow (up to 50 hours). Experience indicated the desirability of reducing the amount of dissolvent used in the second portion of the dissolution by 30 percent (for NRX fuel) to 50 percent (for NRU fuel) to avold high acid conditions in the final dissolver product.

While dissolving the first increment of the last three batches of NRU fuel, the catalyst concentration was increased and a longer digestion period (14 hours) was used. In each case, a highly acid deficient solution was obtained. These solutions were held and blended with the highly acidic solutions obtained in the second portion of each dissolution. 'The resulting blends were close to flow sheet specifications and required little additional adjustment. On the last two batches, however, samples of the final blends contained a solid precipitate, the main constituent of which was mercury. In the final batch, the precipitate was redissolved by reacidification and digestion of the solution. The normal feed adjustment was then carried out without further complication.

After processing of the JRR-2 fuel was completed, a heel cleanout of the dissolver indicated that nearly complete dissolution had been achieved. For the NRX fuel, however, it was necessary to make three more extensive heel cleanouts to ensure that all the fuel had been dissolved. For the NRU fuel, a considerably longer digestion period for the last batch was used, thereby making it necessary for only one heel cleanout to be made.

1.13 Hexone Extraction of Uranium. The Hexone extraction equipment was started up and operated on three separate occasions following processing of the JRR-2, NRX, and NRU fuels through the D cell dissolution equipment. Because of the limited volume of storage for dissolver product when the continuous headend process was not being used, the product from dissolution of each fuel type had to be processed through the solvent extraction equipment before dissolving operations could be resumed.

The Clarkson feeder (Section I-1.4) which was recently installed to correct feed control difficulties from $\mathrm{N}$ Cell storage to the $\mathrm{P}$ Cell extraotion column was used for the second time, and no problems were encountered. Good control of the feed rate was maintained at all times at an average of 18 to 20 liters per hour. 'I'his value approximates the maximum capacity of the feeder as it was installed, but if the necessity arises the rate may be easily increased by interchanging the feed cups with larger ones.

Because of the dilute uranium solutions produced in $\mathrm{D}$ Cell, a dilute flow sheet with a nominal uranium concentration in the feed of $10 \mathrm{grams} / \mathrm{liter}$ was used for each of the extraction runs. Dissolution of NRX and NRU fuel resulted in solutions containing only 1 to 2 grams/liter uranium, but these solutions were blended to about $10 \mathrm{grams} /$ liter of uranium by mixing with more concentrated uranium solution of Vycor glass leachate (Section I-1.3) which had been previously stored in $\mathrm{N}$ Cell. 
Decontamination in the three Hexone extraction cycles was good and the product easily met all specifications. Equipment performance for the Hexone extraction process was generally good.

\subsection{Recovery of Uranium from EBR-I Core 2 Melt (M. E. Jacobson, Chemistry Section; G. F. Offutt, Process Engineering Section)}

Core 2 of Experimental Breeder Reactor I waspartially melted in-reactor, and in this condition it represented a unique problem for the recovery of the approximately $\$ 500,000$ worth of enriched uranium. The melt contained uranium, zirconium, and stainless steel from the fuel, and sodium and potassium from the reactor coolant. Because of the safety problems associated with this material, and the unusual and heterogeneous composition, the fuel was dissolved in $1-\mathrm{kg}$ batches in a shielded cell under direct visual surveillance. The pieces of melt and relics of cladding and fuel rod dissolved readily in $12 \mathrm{M}$ nitric acid- $0.6 \mathrm{M}$ hydrofluoric acid solution with the reaction controlled by the rate of addition of the reagent. A geometrically safe dissolver fabricated from Carpenter-20 stainless steel was used. The uranlum was decontaminated by conventional solvent extraction techniques. The operation proceeded without difficulty with six batches of fuel being dissolved per day. The successful recovery of this uranium at an out-of-pocket cost of $\$ 0.38 /$ gram suggests that other nonspecification fuels of unusual composition can also be processed economically at ICPP. The development work preliminary to this recovery was reported in the preceding Annual Report [1] and the details of the campaign are reported in IN-1088 [2].

\subsection{Recovery of Uranium from EBR-II Vycor Glass Molds \\ (R. D. Modrow, G. F. Offutt; Process Engineering Section; M. E. Jacobson; Chemistry Section)}

About $30.6 \mathrm{~kg}$ of 50 percent enriched uranium were recovered from broken Vycor glass molds that are used to cast fuel pins at the EBR-II Fuel Cycle Facility. Uranium was leached from the glass scrap with nitric acid in the ICPP Multicurfe Cell and extracted from the leachate in the ICPP extraction system. Two runs--one in July 1966 and one in January 1967 lasting about three weeks each--were made during FY 1967. They will continue at approximately six-month intervals as long as fuel is processed routinely in the EBR-II Fuel Cycle Facility.

1.31 Process Description. The glass arrived at the ICPP Multicurie Cell, a shielded remote-handling cell, in three-gallon cans contained in a lead cask. After transferring a can inside the Multicurie Cell, the glass was poured into an 11-inch-OD plastic vessel which served as a dissolver. Then, a fixed volume of $6 \mathrm{M} \quad \mathrm{HNO}_{3}$ was added to leach the uranium from the glass. After overnight sparging of the glass-acid mixture, the resulting leachate was decanted, and the glass was rinsed three times with water. During the first run the leachate and rinses from each bucket of scrap were immediately transferred to a critically safe collection vessel in the ICPP uranium recovery cell $(J-C e l l)$ and combined for an overall uranium input measurement; during the second run the leachate and rinses were transferred to a six-inch-ID vessel where thorium oxide $\left(\mathrm{ThO}_{2}\right)$ solids were allowed to settle out before transferring the decanted leachate to $\mathrm{J}-\mathrm{Cell}$. (Thorfum oxide is used to lubricate the glass molds at EBR-II before the uranium is cast in them, and a large quantity - up to 15 weight percent of the glass -- was present as $\mathrm{ThO}_{2}$ with the glass scrap.) 
Nuclear safety was ensured in the Multicurie Cell by allowing a maximum of only eight liters of solution in the dissolver vessel at one time. The sixinch-ID settling vessel was dimenslonally safe; it was placed more than three feet from the dissolver so that there was negligible interaction between the two.

Following the leach and rinse operations, the glass was returned to the transfer can and sent to the burial grounds. The $\mathrm{ThO}_{2}$ solids separated from the leachate were also transferred to cans (which contained vermiculite to soak up liquid) and buried.

After making input measurements in $\mathrm{J}$ Cell, the solution was transferred to $\mathrm{N}$ Cell for interim storage until it can be processed through the hexone solvent extraction system with dissolver product from future processing of aluminum fuels.

1.32 Processing Experience. Seventeen cans of glass were leached during the first run, and eleven were leached during the second run. Separation of the $\mathrm{ThO}_{2}$ solids by settling in the six-inch-ID vessel was very successful during the latter run. This separation was made because solvent extraction experiments on the leachate from the first run indicated that the solids contributed to the formation of emulsions. Analysis of the $800 \mathrm{ml}$ of solids that were collected indicated that they contained only 0.35 percent uranium by weight.

Material balances made at the EBR-II. Fuel Cycle Facility indicated that the first glass shipment contained $23.8 \mathrm{~kg}$ of uranium and the second shipment contained $11.9 \mathrm{~kg}$. About $18.7 \mathrm{~kg}$ of uranium were recovered from the first and $11.9 \mathrm{~kg}$ were recovered from the second for recoveries of 78 percent and essentially 100 percent, respectively.

Scrap containing irradiated fuel that was out of the reactor only 50 days was processed; however, most of it was at least 120 days cooled. During the first run some buckets containing up to 18,000 curies of radioactivity were handled; however, troublesome floor contamination outside of the Multicurie Cell was experienced with these full, high-activity-level cans. Experience showed that when the cans were less than $2 / 3$ full of glass, and contained less than 12,000 curies of radioactivity, processing was relatively easy.

In the future the processing scheme will be improved by having the scrap shipped in cans with liquid-tight stainless steel liners. Leaching will then be done in the cans, and the troublesome transfer of glass to and from the dissolver will be avoided. The cell will become less contaminated and a savings in cleanup time is expected at the end of each run.

\subsection{ICPP Modifications}

(R.D.Modrow, J. C. Petrie; Process Engineering Section)

Advantage has been taken of the standby status of the ICPP during WCF operation to modify equipment for improved operation. Equipment deficiencies noted during zirconium fuel processing have been corrected. Natural recirculation loops on the aluminum fuel dissolvers have been added to improve uniformity of the dissolver product and to decrease mercuric nitrate consumption. A Clarkson feeder, installed to transfer uranium product from intercycle storage to the second extraction cycle at a uniform flow rate, has been proved in limited plant operation. The aluminum fuel charging cave is being modified to accommodate ATR fuel and provide interim storage for more fuel elements. A solid 
bowl certrifuge is being installed to clarify column feed and thereby eliminate plugging of process lines and lessen interface crud formation. Design work is nearly complete on a product wash column in the first cycle extraction process and for replacing the two-inch-diameter columns in the second extraction cycle with five-inch-diameter columns.

1.41 Aluminum Fuel Headend. Two major modifications to the aluminum fuel processing headend are being made. The first, the addition of a recirculating loop on each of the two dissolvers for aluminum fuel, is expected to reduce the consumption of mercuric nitrate catalyst by a factor of three for the same dissolution rate [3]. In addition, the product composition is expected to be more uniform. Second, the chute to the charging cave over the dissolvers is being changed to accept the longer ATR fuel elements, and the shielding on the charging cave is being increased to allow interim storage of more fuel elements.

1.42 Zirconium Fuel Headend. Several alterations in the zirconium headend should result in increased dissolution rate, decreased operating problems, and the ability to recover rare gases from zirconium fuels. First, operation of the dissolver at both a higher liquid level and a higher temperature will be made possible by raising the off-gas outlet line and increasing its size. A ten percent decrease in the volume of liquid waste is expected to result from a potential 0.1 mole per liter increase in the zirconlum concentration made possible by the changed operating conditions. Second, an alternate acid feed line at the top of the dissolver charging chute is being added to break fuel element bridges that occur occasionally in the charging chute. Dissolver acid will normally be added near the bottom of the dissolver; however, if bridging occurs, acid will be added at the top of the chute to dissolve some of the bridged fuel, allowing it to fall to the bottom of the dissolver. Third, because of mechanical and electrical difficulties, an off-gas blower is being replaced with a steam jet. A new line being installed in conjunction with the new jet will enable routing of the dissolver off-gas through the Rare Gas Plant as an alternate to a direct vent to the stack. In the past, the dilute hydrogen-air mixture from the dissolver was not routed to the Rare Gas Plant; however, after installation of interconnecting piping, the hydrogen-rich off-gas steam from zirconlum fuel dissolution can be processed for rare gas recovery. An integrator on the dissolver off-gas hydrogen analyzer will enable calculation of the approximate amount of undissolved fuel in the dissolver, thus providing better process control. A fourth change will provide separate borated process water systems for the dissolver and condenser cooling jackets which were originally connected in series. Originally, it was impossible to heat the dissolver and cool the condenser at the same time. Now, a new heat exchanger will allow a higher operating temperature in the zirconium fuel dissolver than in the condenser.

1.43 Column Feed Clarification. Aluminum dissolver product and complexed zirconium dissolver product are both processed through the same first-cycle extraction equipment. In the past, undissolved solids have contributed to line plugging and interface crud formation with these dissolver products. To minimize these difficulties, a common feed clarification system will be installed to remove solids from dissolver solutions before they are fed into the firstcycle extraction system. A solid bowl centrifuge was selected because it has been proved in highly radioactive service, is abrasion resistant, and requires little maintenance. When removal of solids from the centrifuge is recessary, the dissolver product will bypass the centrifuge, and the cake in the centrifuge howl will be washed with the use of high-pressure sprays. Finally, the washed 
solids will be slurried and transferred to waste storage via the Process Equipment Waste system.

1.44 First-Cycle Process Piping. Piping changes on the headend evaporator will permit, during zirconium fuel processing, an aluminum nitrate scrub stream and an organic wash stream to be concentrated independent of any zirconium-bearing stream. This mode of operation -- previously not possible because of the Instability of the zirconfum-bearing solutions when heated [4] -will reduce the volume of waste produced by an estimated ten percent during future zirconium processing campaigns; a modest increase in the processing rate for zirconium dissolver product may also be realized. The headend evaporator will continue to be used to concentrate combined aluminum dissolver product and recycle streams before uranium recovery in the extraction columns.

1.45 Increased Capacity of Hexone Cycles. Design work has been completed on a project to replace the two-inch-diameter columns in the second cycle of the Hexone solvent extraction system with five-inch-diameter columns. With the larger columns, a major plant capacity limitation will be removed.

1.46 First Cycle Product Wash. A new perforated-plate, pulsed column will be installed in the first-cycle extraction process to replace an existing seven stage mixer-settler which removes residual organics from the product prior to its entry into the intercycle evaporator. Performance, throughput, and recurring mechanical problemis prompted the planned replacement of the mixersettler.

1.47 Clarkson Feeder. In the past, product from intercycle storage has been transferred to the second extraction cycle by a Lapp reciprocating-type pump. Irregular feed rates from this pump have contributed to system instability. A Clarkson feeder, which has small cups on a motor driven rotating wheel, has replaced the reciprocating pump as a metering device, and it has been shown to deliver a more uniform flow to the IIA column. Uranium solutions have been transferred via the Clarkson feeder with excellent results; no mechanical problems have occurred and the uniform feed rate to the IIA column has improved its operating stability. 
2.1 Dissolution of Aluminum-Uranium-Silicon Alloys

(Bernice E. Palge; Chemistry Section)

Fabricators of reactor fuel have requested that substantial quantities of silicon be allowed in the fuel core alloy because it suppresses formation of $\mathrm{UAl}_{4}$, stabilizes $\mathrm{UAl}_{3}$, and thus improves the fabrication characteristics of the alloy. A joint study is being made by the Metallurgical Development Section of the Reactor Engineering Branch and the Chemistry Section of the Chemical Technology Branch to determine the advantages and disadvantages of the use of silicon in test reactor fuel elements. This investigation is to cover all phases of the fuel cycle and includes metallurgical studies and laboratory tests of the effect upon chemical reprocessing. The present study indicates no adverse effects of the silicon on dissolution rates of the alloys. Future reports will cover the effects of the silicon upon extraction and solids handling in the chemical reprocessing of reactor fuels.

In the present work only two and three component alloys were used in order to obtain an accurate impression of the origin of the effects noted. In earlier dissolution studies $[5,6]$, the aluminum-silicon alloys contained other metal constituents, and the uranium-aluminum alloys were usually clad in aluminum alloy. Fourteen castings of various alloys of aluminum, uranium, and silicon (simulating fuel meat and cladding) were prepared by the Metallurgical Development Section, rolled to 0.10 -inch-thick sheets, and cut into coupons. The alloys studied contained 0,22 , and 31 percent uranium, a range of silicon contents from 0 to 11 percent, and the remainder aluminum (99.9 percent pure). In the uranium alloys, the uranium contents were selected to be representative of the fuel plate core composition in 400- and 500-gram ETR fuel elements. The particular levels of silicon used were selected on the basis of the solubility of silicon in aluminum and the proposed levels in fuel meat and cladding.

Dissolution tests were initiated in $6.6 \mathrm{M}$ nitric acid $-0.007 \mathrm{M}$ mercuric nitrate at the boiling point $\left(103-104^{\circ} \mathrm{C}\right)$ using $4 . \overline{8}$ moles of acid per mole of aluminum and a uniform surface area to volume ratio. All dissolutions were continued until no metal remained. The data for the amounts dissolved were obtained by analysis of the solutions. The instantaneous dissolution rates for the alloys are reported (Table II) as milligrams of aluminum dissolved per square centimeter of surface per minute $\left(\mathrm{mg} / \mathrm{cm}^{2}-\mathrm{min}\right)$ at the level of $30 \mathrm{grams}$ per liter of aluminum in the dissolver solution. Since the early portions of the dissolution obeyed a parabolic rate law, the instantaneous dissolution rates were determined from the slope of a graphical presentation of the square of the aluminum concentration versus the dissolution time.

The dissolution rates measured for these alloys are satisfactory for processing schedules at the ICPP and are comparable to rates measured previously for pure aluminum. The acidity of the dissolver solutions varied from about 1.5 to $3.2 \mathrm{M}$ at 30 grams of aluminum per liter, but no correlation was evident between the acidity and the instantaneous dissolution rates. The dissolution rates for aluminum are depressed by the presence of uranium in the alloy, especially when it does not contain silicon. This effect is far in excess of the dilution of the alloy by the uranium on either a volume or atomic basis. The presence of silicon in aluminum-uranium alloy at any concentration from 0.6 to 5 percent enhances the dissolution of the aluminum. Possibly, there is 


\section{TABLE II}

INSTANTANEOUS DISSOLUTION RATES

FOR ALUMINUM-URANIUM-SILICON ALLOYS[a]

$$
\left(\mathrm{mg} / \mathrm{cm}^{2}-\mathrm{min}\right)
$$

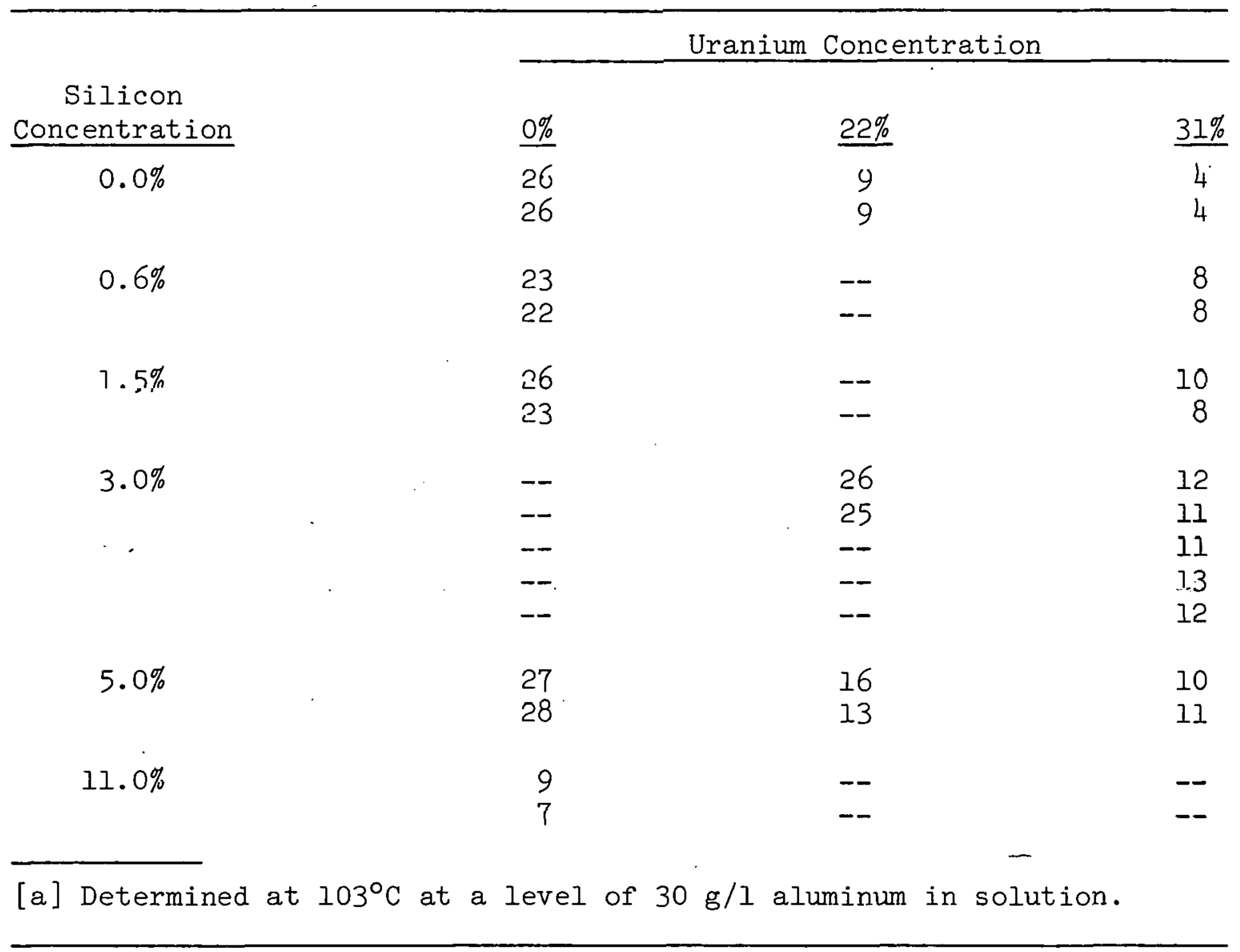

a maximum instantaneous dissolution rate for aluminum-uranium alloys with 3 percent silicon present, but the total time required for the dissolution was about the same as for the other silicon-containing alloys indicating that only the initial rate was higher. The five values presented in Table II for 31 percent uranium3 percent sllicon are for alloys which were rolled different numbers of times to achieve the same thickness reduction; no difference in rates was observed. The dissolution rates for the aluminum alloys which contained no uranium decreased when the silicon content exceeded 5 percent. In earlier studies [5] with aluminum alloys containing small amounts of other metals, this effect occurred at a lower silicon content.

No difference was found in the dissolution rates for rolled and cast aluminum coupons. The dissolution rate of $26 \mathrm{mg} / \mathrm{cm}^{2}-\mathrm{min}$ for pure aluminum reported in Table II was for coupons rolled to 0.1-inch thickness. A cast ingot. of the pure aluminum, machined to the same stze coupons and dissolved at identical conditions, had a dissolution rate of $30 \mathrm{mg} / \mathrm{cm}^{2}-\mathrm{min}$. This is comparable, considering the difference in temperature and catalyst, to $17 \mathrm{mg} / \mathrm{cm}^{2}-\mathrm{min}$ obtained for cast coupons at $90^{\circ} \mathrm{C}$ and $0.005 \mathrm{M}$ mercuric nitrate showing that the new data can be 
compared directly with earlier data for various commercial aluminum alloys [5].

Figure 1 shows typical dissolution curves for 31 and 22 percent uranium alloys. It shows that during the early stages of the dissolution with the 31 percent alloy, and for the complete dissolution with the 22 percent alloy, there was preferential dissolution of aluminum compared to uranium. In the alloys containing 22 percent uranium this effect was greater than in the alloys containing 31 percent uranium. For each alloy the difference between the fraction of uranium and aluminum dissolved was fairly constant during the dissolution of

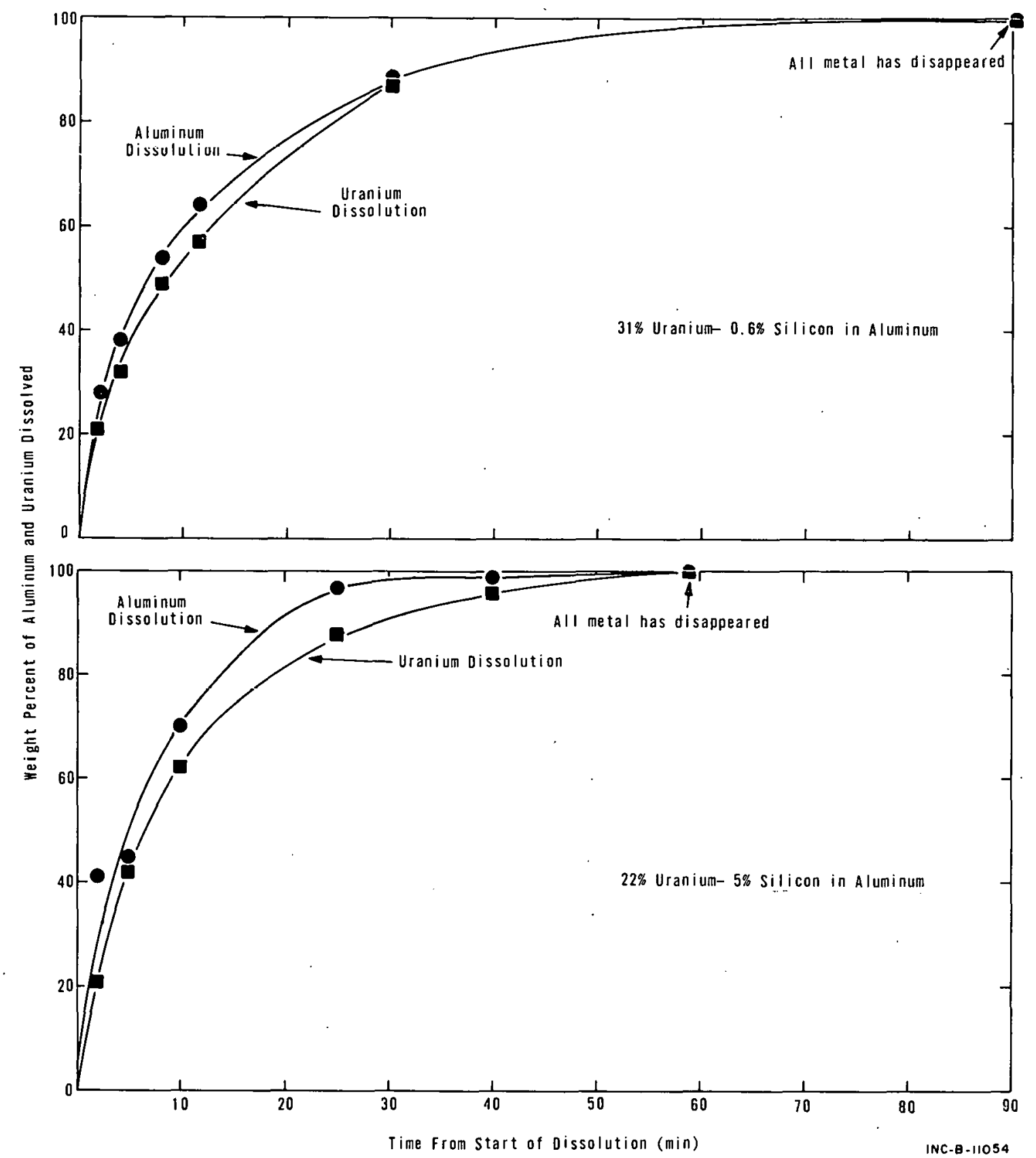

Fig. 1 Comparison of aluminum and urantum dissolution in aluminum-uranium-silicon alloys. 
the first half of the coupon. For some dissolution operations, homogeneous dissolution of uranium and aluminum is assumed in the criticality calculations. This evidence of slight preferential dissolution of aluminum over uranium should be taken into consideration in the criticality evaluation of these operations.

\subsection{Dissolution of Aluminum Alloy 2219}

(R. G. Butzman, Chemistry Section)

Aluminum alloy type 2219-T62 is currently under consideration as a possible cladding material for future test reactor fuel assemblies. Type 2219 is an aluminum-copper alloy developed especially for elevated temperature applications; it has higher strength in. the temperature range, 260 to $316^{\circ} \mathrm{C}$, than any other wrought aluminum alloy presently avallable.

Dissolution rate measurements for 2219 aluminum were performed on coupons and small unirradiated test reactor fuel plates in $6.0 \mathrm{M} \mathrm{HNO}$. catalyzed with mercuric nitrate at the bolling point. The mole ratio of nitric acid.to aluminum was $4,8 / 1$. Table III lists the rate data obtained.

TABLE 1.11.

DISSOLUTION RATES FOR TYPE 2219. ALUMINUM IN 6.0 M: HNO $_{3}$. AT BOILING

\begin{tabular}{|c|c|c|c|c|}
\hline Sample & Metallurgical & State. & $\begin{array}{c}\text { Hg Catalyst } \\
\text { Concentration } \\
\mathrm{M} \\
\end{array}$ & $\begin{array}{c}\text { Instantaneous Dissolution } \\
\text { Rate at } 3.0 \mathrm{~g} / \mathrm{l} \\
\text { Dissolved } \mathrm{Aluminum} \\
\mathrm{mg} / \mathrm{cm}^{2}-\mathrm{min} \\
\end{array}$ \\
\hline Coupon & тб́: & & U.'2 & 0.9 \\
\hline Coupon & T62 & & 0.05 & 0.7 \\
\hline Coupon & $\mathrm{T} 62$ & & 0.005 & 1.4 \\
\hline $\begin{array}{c}\text { Test reactor } \\
\text { fuel plate }\end{array}$ & T62 & & 0.005 & 0.5 \\
\hline $\begin{array}{c}\text { Test reactor } \\
\text { fuel plate }\end{array}$ & Hot rolled & & 0.005 & 0.3 \\
\hline
\end{tabular}

Coupons of this alloy in the T62 state and fuel plates clad with this alloy; dissolved at a rate of about one $\mathrm{mg} / \mathrm{cm}^{2}-\mathrm{min}$, which-is about $1 / 25$ the rate of high purity aluminum. These preliminary experiments with 2219: T62 aluminum suggest that dissolution in mercury-catalyzed nitric acid is too slow for normal plant production rates.

An extensive study of dissolution rates for a variety of aluminum alloys. in. mercury-catalyzed nitric acid was made by Fletcher and others in 1962 [5]. Their work showed that copper and nickel ions in solution.produced an anticatalytic effect. Attempts by Fletcher's group to overcome the passivating effects of copper by "contact activation" and increased mercury catalyst concentration were unsuccessful. Alternate methods that may be suitable for dissolving this 
alloy, but were not investigated at this time, include electrolytic dissolution or dissolution in sodium hydroxide [7].

\subsection{Corrosion Observations During Zirconium Fuel Reprocessing (D. W. Rhodes, T. L. Hoffman, C. A. Zimmerman; Chemistry Section)}

2.31 Dissolvent Make-Up and Storage Equipment. The dissolvent make-up and storage tank, constructed of carbon steel lined with "Goodyear - Plioweld", was examined after one and one-half years service. This vessel was exposed to aqueous $7 \mathrm{M}$ hydrofluoric acid solution containing $4 \mathrm{~g} / \mathrm{l}$ of boron (added as boric acid) and a trace of nitric acid (0.03M) during part of this service. The examInation revealed that the coating was silghtly discolored in the bottom section of the vessel but was still soft and pliable. The cooling coil, boron detectors, and stirring equipment, all fabricated from Monel, showed less than 2.0 mils per month corrosion. A loose black deposit, calculated as representing approximately $2-1 / 2$ percent of the lining on the lower $1 / 3$ of this vessel, was found on the bottom of the tank. Analysis of this deposit indicated that it contained copper sulfide and elemental sulfur. The copper presumably came from the Monel fittings in the tank and the sulfur from the tank lining. Both the tank and the fittings are still in serviceable condition.

2.32 Headend Dissolver. Corrosion of the headend dissolver, constructed of Monel-400, was evaluated during processing operations. A 3/4-inch-diameter Monel pipe, extending from the top to the bottom of the vessel, was installed temporarily in the headend dissolver to monitor corrosion during processing. Inspection of this pipe indicated a uniform corrosion rate of $7.5 \mathrm{mils}$ per month for the operating dissolver.

2.33 Product Evaporator. The product evaporator is constructed of Type $304 \mathrm{~L}$ stainless steel with Type 304 stainless steel plates containing boron suspended in the disengaging head space for criticality control in the event of a malfunction. Stainless steel corrosion coupons (Type $304 \mathrm{~L}$ and Type 304 containing 1.5 percent boron) suspended in the disengaging section of this vessel were examined after 20 months of exposure. Based on the results of this examination, the stainless steel plates containing boron lost an estimated 1.0 mil of metal from each exposed surface. The Type 304L stainless steel of the vessel body lost 0.02 mil of metal.

Laboratory corrosion tests of stainless steel containing boron, carried out in the vapors above solutions undergoing evaporation (Table IV), indicate that nitric acid processing solutions containing $0.1 \mathrm{M}$ fluoride, and no aluminum for complexing, lead to excessive corrosion, while solutions containing no fluoride or $0.1 \mathrm{M}$ fluoride along with excess aluminum for complexing ( 3 moles aluminum per mole fluoride) result in low corrosion rates.

2.34 Titanium Equipment. Fallure of a titanium elbow in a thermosyphon evaporator during a recent zirconium processing campaign was apparently due to attack by the processing solutions containing complexed fluoride. This attack was accelerated in a stressed area along the inside radius of a mitered and welded elbow at the bottom of the thermosyphon section. This evaporator was not being used, but had not been removed from the processing system since it was presumed that the completely complexed stream in a stagnant condition would not be excessively corrosive. After the failure, the idle vessel was removed from the processing system for the remainder of the campaign. 


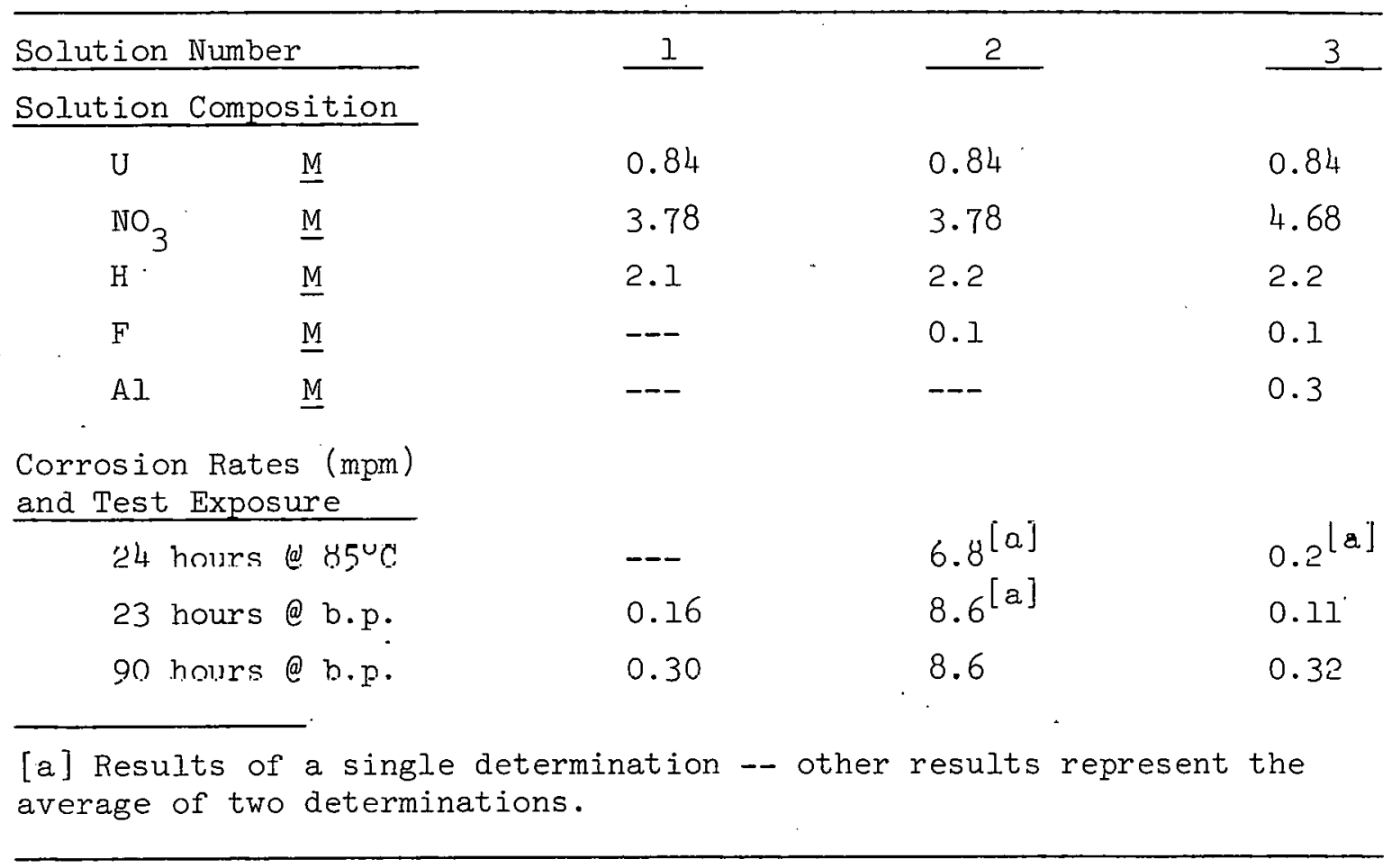

Laboratory corrosion tests (Table $\mathrm{V}$ ) indicate that titanium experiences severe corrosion and is not acceptable for service in normally complexed zirconium fluoride processing solutions. Further tests are being undertaken to determine whether fluoride at any concentration may be allowable for zirconium processing streams in contact with titanium.

2.35 Vitreous Enamel Flowmeter Lining. An elestrnmagnetic flowmeter with a vitreous enamel lining which was used during aluminum fuel processing failed in zirconium fuel processing service. Specimens of the blue vitreous enamel material (Albyline), used for lining the electromagnetic flowmeter, were tested in a number of processing and decontaminating solutions. As a result of these tests it was concluded that the vitrenus enamel was resistant to aluminum nitrate solutions, but was unsuitable for extended use in processing solutions containing fluoride, even in the presence of excess aluminum nitrate as a complexing agent.

Corrosion tests were run with solutions containing fluoride complexed with calcium $[(\overline{\mathrm{C}} \mathrm{a}) /(\mathrm{F})=0.5]$. This greatly reduced corrosion rates compared to those experienced without calcium. The average corrosion rate of 2.8 mils per month was sufficiently low to permit limited use of this lining material in processing of calcium-complexed streams containing fluoride, eg, feed to the Waste Calcining Facility. The enamel appears sufficiently resistant to alkaline decontaminating agents to withstand the short exposures used for decontamination. 
TABLE V

CORROSION OF TITANIUM IN SYNTHETIC ZIRCONIUM PROCESSING SOLUTIONS $\operatorname{AT} 35^{\circ} \mathrm{C}$ [a]

Complexed Dissolver Product First Cycle Raffinate

Solution Number
Solution Composition

$\begin{array}{llllll}F & \text { M } & 5.32 & 4.43 & 3.74 & 3.81 \\ \mathrm{Zr} & \underline{M} & 0.76 & 0.65 & 0.63 & 0.53 \\ \mathrm{Al} & \underline{M} & 0.41 & 0.37 & .0 .56 & 0.45 \\ \mathrm{~B} & \underline{M} & 0.28 & 0.30 & 0.25 & 0.25 \\ \mathrm{H} & \underline{M} & 1.84 & 2.02 & 1.33 & 1.75 \\ \mathrm{U} & \mathrm{g} / \mathrm{I} & 1.13 & 1.0 & -\ldots & -.-\end{array}$

Corrosion Rates (mpm) on Welded Specimens

$\begin{array}{rllll}20 \text { Hour Exposure } & 56 & 590 & 225 & 750 \\ 87 \text { Hour Exposure } & 14[\mathrm{~b}] & -- & -- & -- \\ 110 \text { Hour Exposure } & -- & -- & 43^{[b]} & --\end{array}$

[a] Rates are averages of two or more determinations.

[b] Decrease in corrosion rates in extended tests may reflect depletion of the reactive components in the solution.

\subsection{Nuclear Safety in the ICPP Dissolvers}

(W. G. Morrison; Chemical Technology Staff)

Increased uranium loading of the Engineering Test Reactor (ETR) fuel elements prompted a reappraisal of the nuclear safety aspects of the ICPP continuous dissolver. The aluminum-alloyed ETR fuel elements were increased to $505 \mathrm{~g} \mathrm{U}-235$ maximum from $405 \mathrm{~g} \mathrm{U-235}$, the previous high loading. Meat composition of the $505 \mathrm{~g}$ uranium-aluminum alloyed fuel elements is $28 \mathrm{wt} \%$ uranium, 93 percent U-235. The nuclear evaluation of the ICPP dissolver (7.5inch inside diameter, partially reflected) showed that the highest keff calculated was about 0.87 for ETR fuel meat at a metal volume fraction (MVF) of 0.15

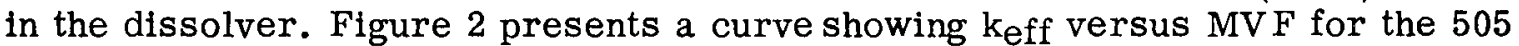
g U-235 fuel elements. A similar reactivity curve with a maximum $k_{\text {eff }}$ of 0.84 at $0.15 \mathrm{MVF}$ was obtained for the $405 \mathrm{~g} \mathrm{U}-235 \mathrm{ETR}$ fuel elements (23.8 wt\% uranium). As usual, this evaluation was based on unirradiated fuel with no burnup and no credit for any burnable poison content in the fuel. Also, nuclear safety evaluations of dissolvers for the aluminum process at ICPP are based on fuel element meat composition only, because it would be possible to dissolve aluminum cladding and nonfueled side plates leaving a mass of fuel meat. Metallic fuel is present in the dissolver in varying and unknown configurations throughout the dissolution operation. The entire range of MVF was considered in order to cover any fuel configuration possible. The normal operating $\mathrm{k}_{\mathrm{eff}}$ is 


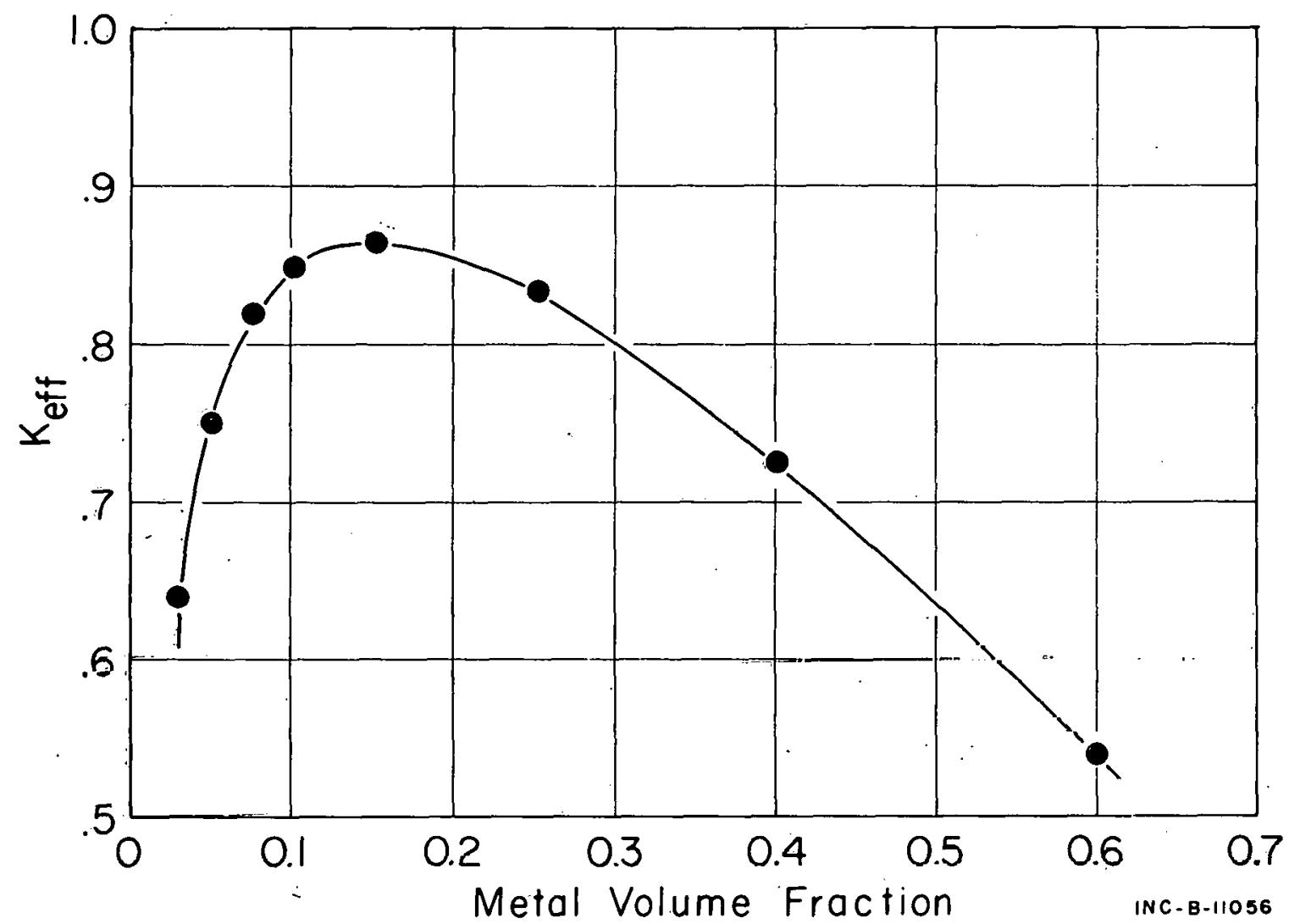

Fig. $2 \mathrm{~K}_{\text {eff }}$ curve for ICPP continuous dissolver containing ETR fuel element meat [28 percent U (93 percent 235)] and water.

appreciably less than the calculated maximum based on the metal volume fraction of 0.60 to 0.65 expected in the dissolver under normal conditions [8].

The nuclear evaluation was performed using the FOG one-dimensional code (NAA-SR-6104) [a] on the IBM-7040. Four-grnup nuclear constants for the diffussion calculations were generated using the GAM-1 (GA-1850) $[\mathrm{b}]$ and TFM= PEST-II (AMTD-111) [C] codes for the fast neutron groups and thermal group, respectively.

[a] NAA-SR-1604, H. P. Flatt, “The FOG One-Dimensional Neutron Diffusion Equation Codes", $\Lambda$ tomics International (1961).

[b] GA-1850, G. D. Joanou and J. S. Dudek, "GAM-1: A Consistent P-1 Multigroup Code for the Calculation of Fast Neutron Spectra and Multigroup Constants," General Atomics (1961).

[c] AMTD-111, R. H. Shuddle and J. Dyer, "TEMPEST-II: A Neutron Thermalization Code”, Atomics International (1961). 


\section{GRAPHITE FUELS REPROCESSING}

Development of a fluidized bed combustion-nitric acid dissolution process for reprocessing graphite (eg, nuclear rocket) fuels at ICPP is underway. The combustion-dissolution process, shown in simple schematic form, in Figure 3, consists of the following steps: (a) burning of the graphite fuels in a bed of fluidized alumina; (b) elutriation of the metal oxide combustion products $\left(\mathrm{U}_{3} \mathrm{O}_{8}\right.$ and $\mathrm{Nb}_{2} \mathrm{O}_{5}$ ) in the off-gas stream from the burner; (c) removal of the elutriated particles from the off-gas by scrubbing with nitric acid, which also dissolves the $\mathrm{U}_{3} \mathrm{O}_{8}$; and (d) separation of the undissolved solids (mainly $\mathrm{Nb}_{2} \mathrm{O}_{5}$ ) from the uranyl solution, which is fed to the solvent extraction system for uranium recovery. Undissolved solids will be monitored for uranium content, and those which contain a significant amount of uranium will be isolated and stored for future processing. This process was selected because of (a) its compatibility with existing solvent extraction facilities at ICPP, (b) its simplicity relative to other graphite fuels processes, and (c) the ease of usage also as a demonstration facility for reprocessing the High Temperature Gas Cooled (HTGR) power reactor fuels.

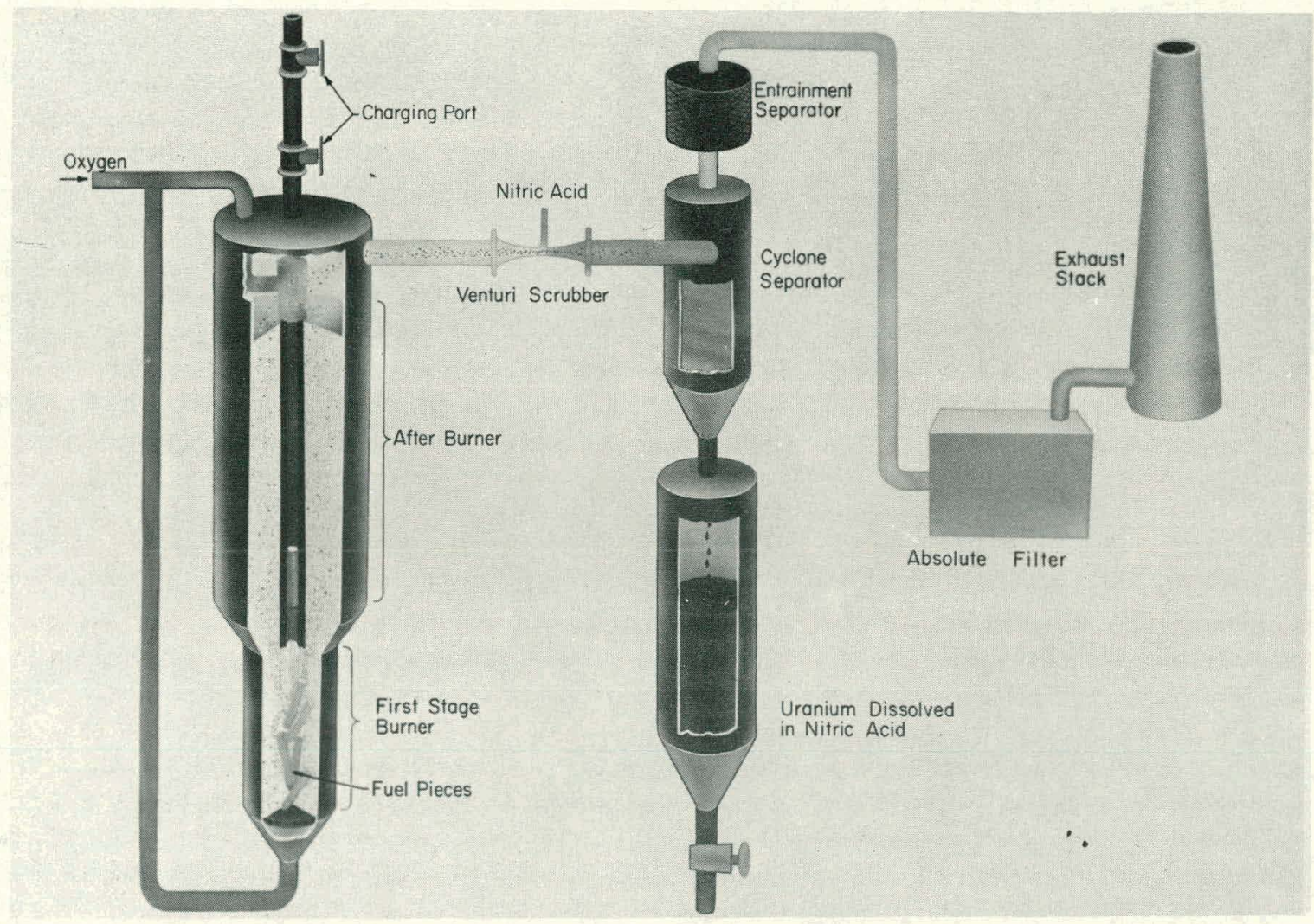

Fig. 3 Combustion-dissolution process for graphite fuels.

A four-inch-diameter fluidized bed graphite fuels burner and dry ash collection system was installed and tested during FY 1966. A description of this pilot plant and the results of the initial tests are reported in IDO-14680[1], the Annual Report for FY 1966. Results from these initial tests revealed that the 
metal oxide combustion products could be separated from the inert alumina bed by elutriation in the off-gas stream. However, during these tests only 65 percent of the graphite in the fuel was burned, and a significant amount of uranium oxide remained in the burner.

Pilot plant development studies at ICPP during the past year have continued to examine the dry physical separation of the metal oxide combustion products from the inert alumina particles in the fluidized bed and to maximize the graphite combustion in the fluidized bed. A moderate laboratory development program was conducted in support of the pilot plant development effort.

3.1 Pilot Plant Studies of the Fluidized Bed Combustion-Nitric Acid Dissolution Process

(L. T. Lakey, A. P. Roeh, D. C. Kilian, O. R. Klemens; Development Engineering Section)

During the fiscal year, additional tests were made in the four-inch-diameter fluidized bed burner, and a graphite fuels pilot plant was fahricated and installed in the High-Bay Chemical Engineering Laboratory. Operational testing of the equipment and initial experimental tests of the burner have been completed in the new pilot plant.

3.11 Fluidized Bed Burner Operation. As previously reported[1], two major problems associated with the in-bed separation of product ash from the inert alumina were (a) the excessive amount of unburned graphite carried overhead and (b) coating of uranium oxide on the alumina bed. These problems have been solved during the past year. In early studies, thirty-five percent of the total graphite in the fuel charged to a single-stage burner was carried overhead with the product ash. Since the burner was operated with an excess of fuel present most of the oxygen was consumed in the lower portion of the burner, leaving an insufficient amount to react with particles released from the burning fuel and rising through the upper portion of the burner. Subsequent tests with a two-stage fluidized bed burner showed that at least 97.5 percent of the graphite in Rover fuel can be burned compared to 65 percent for a single-stage burner. The fluidized bed is continuous between the first and second stages. The secund stage is mounted above and contiguous to the first stage and has a larger diameter than the first stage. The fluidizing velocities in the two stages are made approximately equal by the addition of oxygen to the second stage. Sufficient oxygen is present in the second stage to burn any small graphite particles carried up from the first stage.

Originally, it was concluded from short tests in the single-stage burner that about $4 \mathrm{wt} \%$ of the uranium oxide particles in the fluidized bed were too large to elutriate from the burner: Further examination revealed that the retained uranium was not in the form of large uranium oxide particles but as small particles coated on the alumina. These particles thus appeared in the uranium analysis of the larger size fractions in the fluidized bed samples. In longer runs, the steady state concentration of uranium oxide coating on the alumina particles in the single-stage burner was shown to level out at 2 to $4 \mathrm{wt} \%$. Most of this uranium oxide coating on the alumina can be removed and elutriated from the single-stage burner by fluidizing the bed for aboul lwo hours without charging additional fuel elements. Tests to determine the steady state concentration of the uranium oxide coating on the alumina bed in a two-stage burner are planned. 
Experimental data showing typical uranium behavior in the fluidized bed burner are shown in Figure 4. The lower portion of this figure shows the uranium buildup in the bed during a 51-hour run. Within 15 hours, a steady state level had apparently been reached: at mid-run, an equipment malfunction allowed the temperature to rise and disturb the equilibrium, but within 10 hours after correction was made the uranium level had returned to $4 \mathrm{wt} \%$ and remained in the 2 to $4 \mathrm{wt} \%$ range for the rest of the run.

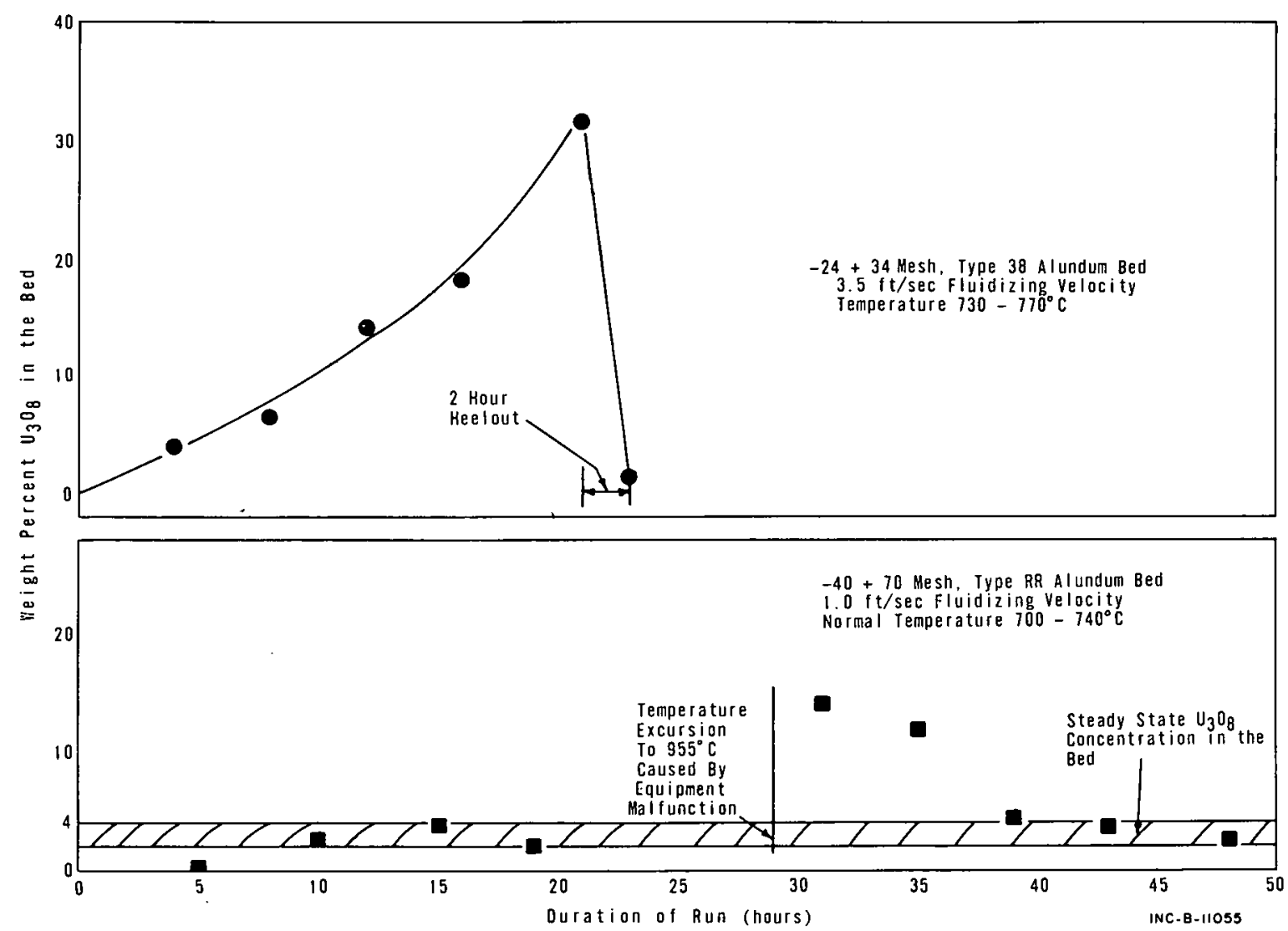

Fig. 4 Uranium bulldup in the fluidized bed during combustion of uranium-graphlte fuels.

The upper curve in Figure 4 represents an unusual run, but illustrates the ease of eliminating excess uranium oxide from the fluidized bed. This run was made with a different type of alumina, a larger alumina particle size, a higher fluidizing velocity, and a higher temperature than with all other runs. During this run, the uranium oxide coated very heavily on the alumina. The coating increased at a fairly steady rate of about $1.5 \mathrm{wt} \%$ per hour over a period of 20 hours. One or a combination of the above four factors is believed to have caused the heavy coating because this is the only run in which it occurred. This uranium oxide coating was subsequently reduced from $32 \mathrm{wt} \%$ to $1.4 \mathrm{wt} \%$, and the uranium oxide was elutriated from the burner by continuing the fluidization for two hours without charging fuel to the burner. Thus, a heavy coating of uranium oxide on the alumina, if it should occur in the future, can be easily removed and elutriated from the burner. At the end of each campaign, the uranium remaining in the bed in a nonelutriatable form can be leached with acid before the bed is discarded. Thus, uranium losses from the burning operation are expected to be negligible. 
3.12 Graphite Fuels Process Pilot Plant. Based on the encouraging results from the four-inch-diameter burner, a graphite fuels pilot plant was fabricated and installed in the High-Bay Chemical Engineering Laboratory. This pilot plant consists of a two-stage fluidized bed burner with a combination wet offgas cleanup and uranium dissolution system and a dry overhead product collection system. The pilot plant is also designed for charging full length Rover fuel elements to the first stage of the burner, thus eliminating the fuel element size reduction facilities that would otherwise be necessary for a Rover fuels process.

(1) Equipment Description The graphite fuels pilot plant is constructed in two modules, (a) burner and dry product collection module and (b) wet off-gas cleanup and uranium dissolution module, with each module having the capability of being operated independently or in conjunction with the other. A simplified flow diagram of the pilot plant is shown in Figure 5.

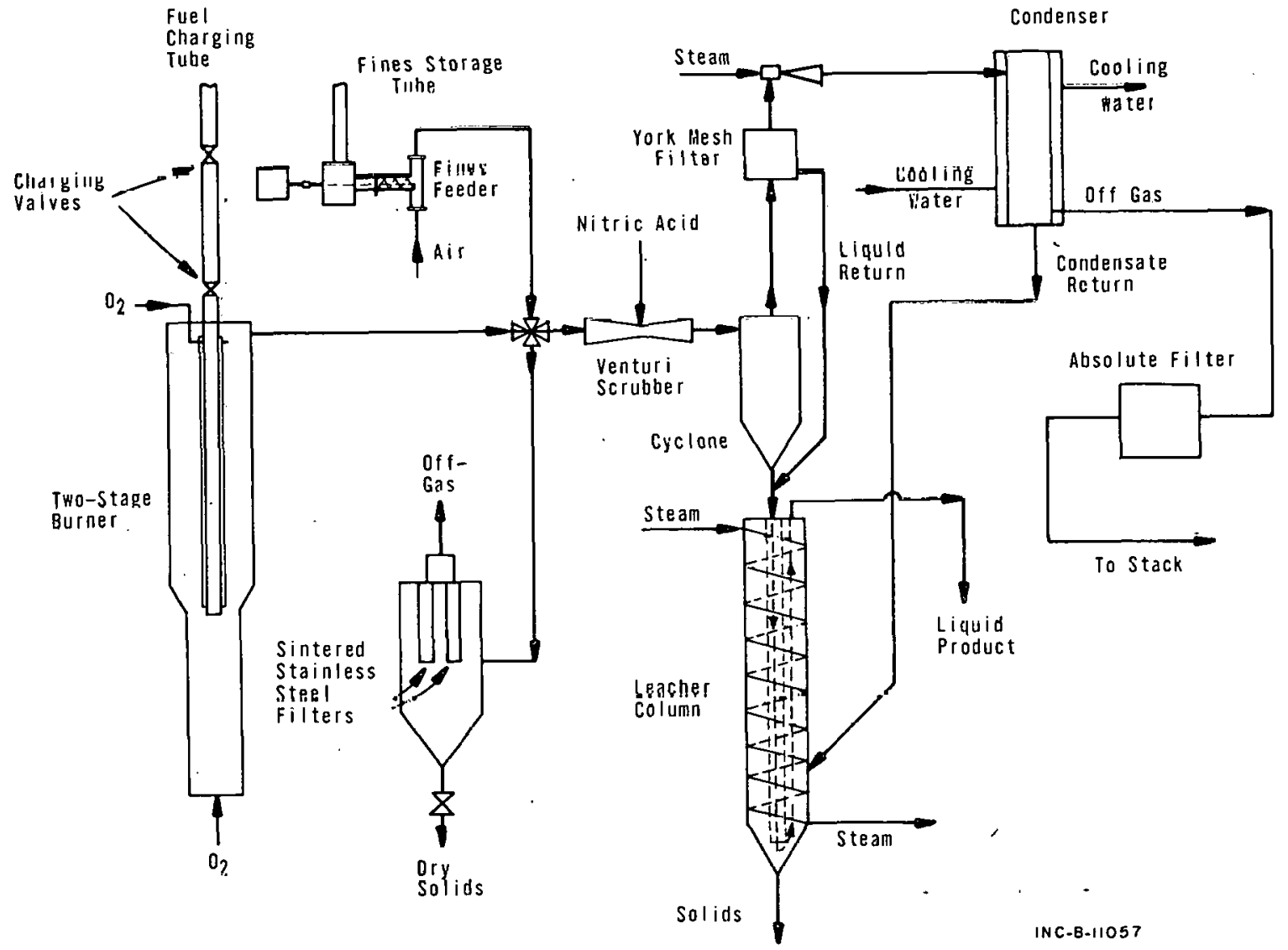

Fig. 5 Graphite fuels pilot plant equipment flow diagram.

The original four-inch-diameter burner $[1]$ is used for the first stage of the two-stage burner; the second or upper stage is constructed from type 316 stainless steel pipe (Schedule 40, six-inch-diameter, and 10 feet long) mounted on top of the first stage with a flanged reducer. Thus, the two-stage burner consists of a continuous fluidized bed, the cross-sectional flow area of the second stage being twice that of the first stage. In a similar manner to the first stage, the second stage is equipped with external electrical heaters for startup and a sheet metal jacket for cooling air. Both sections are insulated with high temperature magnesia insulation. 
Rover fuel elements are charged to the burner through a charging tube extending through the center of the second stage to the top of the first stage. The first stage is fluidized by gas entering the bottom of the burner and the second stage is fluidized by the gas from the first stage plus additional gas that enters the bottom of the second stage through a jacket surrounding the charging tube. Perforated horizontal plates are located in the second stage to reduce the formation of large gas bubbles, smooth the fluidizing action, and increase the residence time of small particles.

Solids elutriated from the burner and carried in the off-gas stream can be collected by a dry collecting system using sintered stainless steel filters or by a wet scrubbing system using nitric acid. The wet off-gas cleanup and uranium dissolution module consists of a venturi scrubber, cyclone, York Mesh demister, uranium dissolution tank, steam-jet exhauster, off-gas condenser, and an absolute filter. A fines feeder for metering fine granular solids into a stream of air is connected to this module to allow the wet off-gas cleanup system to be operated independently of the burner.

The off-gas stream carrying elutriated solids from the burner (or from the auxiliary fines feeding system) is contacted with nitric acid in the venturi scrubber where the solids impinge on the liquid droplets generated in the venturi. Liquid droplets are removed from the gas stream by the cyclone and the York Mesh demister, both of which drain to the dissolution vessel. Because of the large pressure drop through the scrubber, a steam jet exhauster is required to raise the absolute pressure of the off-gas for exhaustion to the building off-gas system. The water vapor is then condensed from the off-gas, and the gas heated above its dew point and filtered by an absolute filter before entering the building off-gas header. Off-gas condensate can be routed to the dissolution tank if it contains a significant amount of uranium, or it can be routed to the cold-waste drain.

Two glove boxes are used in conjunction with the pilot plant unit in order to prevent spread of alpha contamination in the laboratory. Fuel is charged to the burner through a double valve airlock system from a glove box on top of the burner module. Remote actuators for the charging valves are located in the glove box. A full flow sample filter that can be valved into the off-gas system at varlous points to determine the efficiency of the wet off-gas cleanup system is also located in the fuel charging glove box. A second glove box near the bottom of the module contains the fluidized bed sample outlets and the dry product outlet. Samples can be obtained from five locations in the fluidized bed by manipulating sample valves controlled by actuators located in the glove box.

(2) Experimental Results. Detailed experimental studies in the complete pilot unit have not yet been undertaken. However, preliminary studies with the two-stage burner have shown that (a) the fluidized bed can be operated and controlled without difficulty (even with different fluidizing velocities in the two stages), (b) at least 97.5 percent of the graphite charged can be burned in the bed, (c) charging whole Rover fuel elements to the first stage of a two-stage burner is feasible, (d) uranium oxide particles can be elutriated by the off-gas, and (e) continuous operation is possible without frequent bed leaching.

Typical operating conditions for the pilot plant burner are as follows: 


$\begin{array}{ll}\text { Temperature } & 700-800^{\circ} \mathrm{C} \\ \begin{array}{l}\text { Fluidizing Gas Feed } \\ \text { First Stage } \\ \text { Second Stage }\end{array} & 30-100 \% \mathrm{O}_{2} \\ \begin{array}{l}\text { Fluidizing Velocity } \\ \begin{array}{l}\text { Fluidized Bed Height } \\ \text { First Stage }\end{array}\end{array} & 100 \% \mathrm{O}_{2} \\ \text { Second Stage } & 5 \mathrm{ft} / \mathrm{sec} \\ \text { Inert Bed Material } & 7 \mathrm{ft} . \\ & -40+70 \text { mesh Norton RR Alundum }\end{array}$

3.2 Corrosion Observations in the Graphite Burner

(T. L. Hoffman; Chemistry Section)

Following initial tests with unirradiated graphite fuel in the fluidized bed burner, the unit was disassembled and examined for evidence of corrosion. After 73 hours at 600 to $950^{\circ} \mathrm{C}$, plant test components in the graphite burner suffered a maximum corrosion rate of 0.5 mils per month (Table VI). The alloys studied were Types $330,310,304$, Carpenter-20 (Cb) stainless steel, and Nichrome ( $1 \% \mathrm{Mn}, 13 \% \mathrm{Fc}, 15 \% \mathrm{Cr}, \mathrm{Bal}$. Ni). $\Lambda$ ll of these alloys appeared to resist corrosion equally well in the burner environment, which is given in Table VII.

\section{TABLT .VI}

CORROSION OF VARIOUS ALLOYS AFTER

73 HNIIRG TN THF, GRAPHTTF: FT.JFL RIIRNTFR

Temperature: $\quad 600-950^{\circ} \mathrm{C}$

\begin{tabular}{|c|c|c|}
\hline Type Alloy & Plant Test Piece & $\begin{array}{c}\text { Corrosion Rate } \\
\text { (Mils per Month) }\end{array}$ \\
\hline Type 330 SS & Fluidizing Baffle w/o Blade & 0.16 \\
\hline Type $330 \mathrm{ss}$ & Blades for Fluidizing Baffle & 0.28 \\
\hline Type 310 SS & Fluidizing Baffle w/Blades & 0.40 \\
\hline Type $310 \mathrm{SS}$ & Fuel Support Grid & 0.19 \\
\hline Type 304 SS & Baffle Support Rod & 0.05 \\
\hline Type Carpenter-20 ( $\mathrm{Cb})$ & Baffle Support Rod & 0.05 \\
\hline Nichrome & Baffle Support Rod & 0.05 \\
\hline
\end{tabular}

3.3 Leaching of Uranium from Burner Ash

(L. A. Decker; Chemistry Section)

The product from the graphite fuels burner will consist mostly of finely divided $(-100 \mathrm{mesh})$ uranium oxide, $\mathrm{U}_{3} \mathrm{O}_{8}$. Dissolution of the uranium oxide in nitric acid is to be accomplished in a downflow contactor such that the residence time is sufficient to assure complete recovery of all soluble uranium. A series 
$\underline{\text { TABLE VII }}$

COMPOSITION OF THE ATMOSPHERE IN THE GRAPHITE FUEL BURNER

(Percent)

\begin{tabular}{ccccc}
\hline Atmosphere & $\frac{\mathrm{O}_{2}}{46}$ & $\frac{\mathrm{N}_{2}}{54}$ & CO & $\mathrm{CO}_{2}$ \\
Inlet & 2 & 54 & $1-5$ & -- \\
Outlet & $29-43$ \\
\hline
\end{tabular}

of experiments with product from the prepilot plant burner showed that all of the uranium would be dissolved in 15 minutes with $4 \mathrm{M}$ nitric acid at $95^{\circ} \mathrm{C}$. Eight molar nitric acid dissolved all of the uranium in five minutes at $100^{\circ} \mathrm{C}$, and $15.7 \mathrm{M}$ acid accomplished this in six minutes at $80^{\circ} \mathrm{C}$.

\section{SUPPORT STUDIES FOR OTHER SCHEDULED ICPP PROCESSING OPER- ATIONS}

\subsection{Electrolytic Dissolution Studies}

(L. T. Lakey, B. R. Dickey, W. B. Kerr; Development Engineering Section)

The electrolytic dissolution of stainless steel reactor fuels in nitric acid was first tested. by Pitzer [9] in 1951. By 1958, the need for reprocessing capacity for stainless steel and Nichrome fuels appeared to be growing rapidly, and development work on an electrolytic process was started at both the Savannah River Laboratory[10] and the Idaho Chemical Processing Plant (ICPP). Studies at ICPP were directed primarily at the dissolution of fully enriched fuels, the most prominent of which were the stainless steel cermets from the Army Package Power Reactor (APPR) program and the Nichrome cermets from the High Temperature Reactor Experiment (HTRE) in the Aircraft Nuclear Propulsion program. When it became clear in 1965 that only limited quantities of these fuels would require reprocessing, they were assigned to the Savannah River Plant and development work at ICPP was suspended. At that time an electrolytic dissolver, employing the solution-contact principle, had been developed at ICPP to a point where a plant-scale process could be designed[11]. Results from this development program included (a) demonstration of acceptable dissolution rates for actual fuels, (b) determination of the effects of operating variables upon the dissolution rates, and (c) development of methods for controlling the concentration of metals in the dissolver product solution. Fabrication and testing of a dissolver considered suitable for plant installation, however, were not.included in the development program

Recently, the reprocessing of EBR-II fuel was assigned to ICPP. Evaluation of methods for processing the EBR-II and other stainless steel type fuels proposed for future processing has resulted in the decision to install an electrolytic dissolution headend at ICPP. The EBR-II fuel contains a moderately enriched uranium alloy core comprising more than 60 percent of the total element weight, and utilizes a sodium bond between the core and stainless steel cladding, as compared to the greater than 90 percent stainless steel in the cermet fuels 
studied earlier. These differences have made it necessary to reactivate the electrolytic dissolution development program at ICPP.

4.11 The ICPP Pilot Plant Electrolytic Dissolver. A 24-inch-long pilot plant dissolver of the open-top trough design developed during the earlier work, and having 3000-ampere capacity at 20 volts, is being fabricated and assembled into a system for further test work. This dissolver is identical, except for length, to that proposed for plant installation. Pilot plant studies will include (a) prooftesting of the dissolver design for materials suitability, operation, and adequate capacity; (b) evaluation of special hazards such as splashing and evolution of hydrogen resulting from the reaction between the sodium bonding and the nitric acid; (3) evaluation of an electrodeless conductivity measurement system for controlling the concentration of the dissolver product solution; (d) determination of the process significance of small amounts of insoluble alloying agents in the fuel; and (e) determination of the nitric acid consumption at the low metal concentrations proposed for this fuel.

A pictorial drawing of the pilot plant dissolver is shown in Figure 6 . The removable niobium basket will be perforated and slotted on both anode and cathode sides and will be separated from both the anode and cathodic dissolver body by alumina insulating discs. The anode will consist of a 1/4-inch-thick-niobium plate clad with 0.03 inch of 90 percent platinum-10 percent iridium alloy on the surface facing the basket and will be separated from the cathodic dissolver body by alumina insulating discs. Additional insulation will not he required between the back of the anode and the dissolver body because current flow across this small solution gap will be prevented by the valve characteristics of the niobium. The current which flows from the platinfum alloy of the front surface of the anode will also be directed through the basket, due to the valve characteristics of niobium, by bending the niobium anode around the end of the basket, thus making the current path through the basket the shortest path between anode and cathode.

The dissolvent, approximately $3 \mathrm{M}$ nitric acid containing about 10 grams per liter of dissolved metal, enters the bottom of the dissolver and pazses upward through the basket to the level of the overflow weir near the top of the cathodic side of the dissolver. Solution overflowing from the dissolver will be pumped through an external cooler and returned to the dissolver. The metal content of the dissolvent will be controlled by the addition of $4 \mathrm{M}$ nitric acid and simultaneous withdrawal of product solution. A simplified flow sheet of the syotem is shown in Figurc 7. 


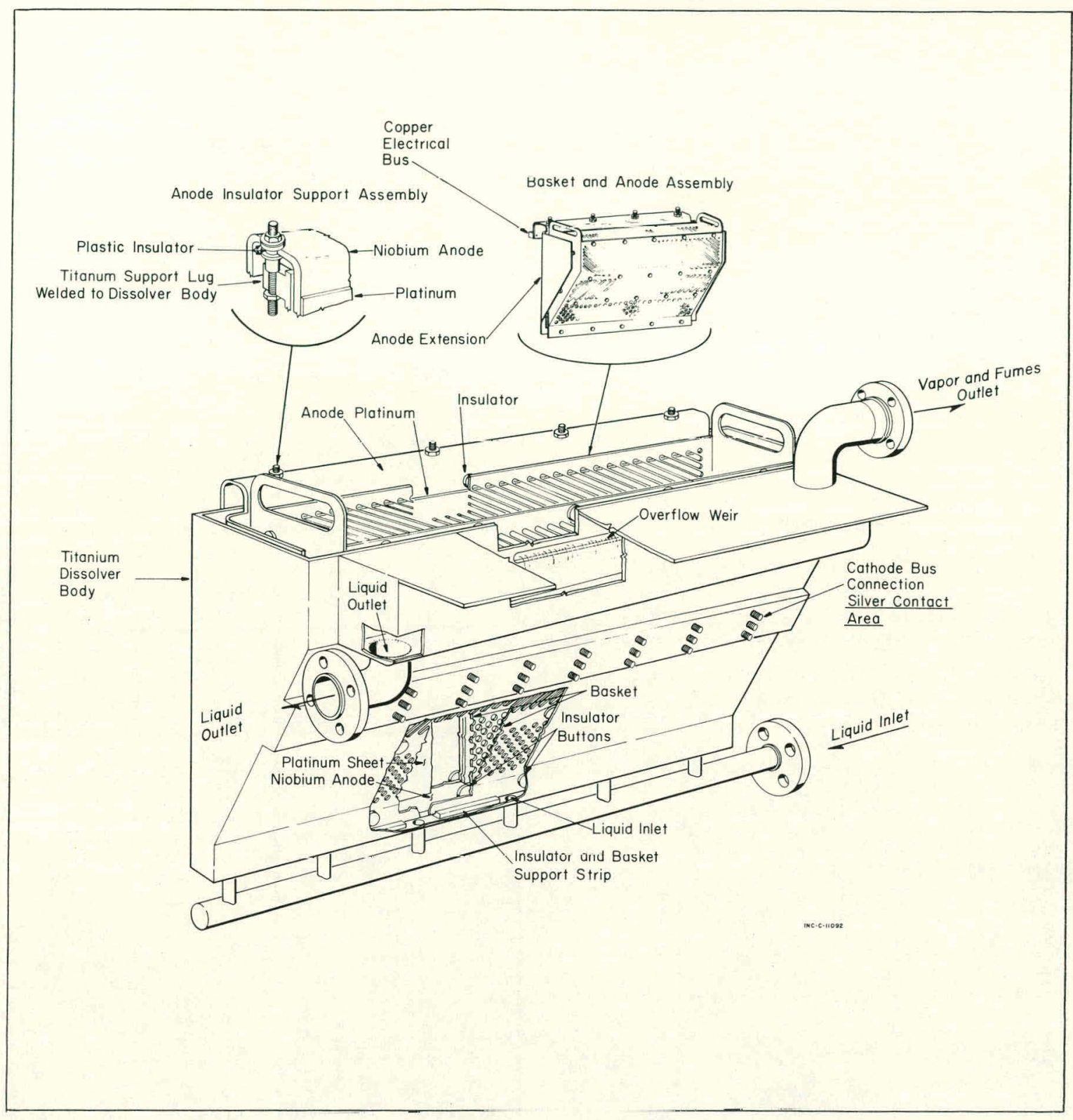

Fig. 6 Electrolytic dissolver. 


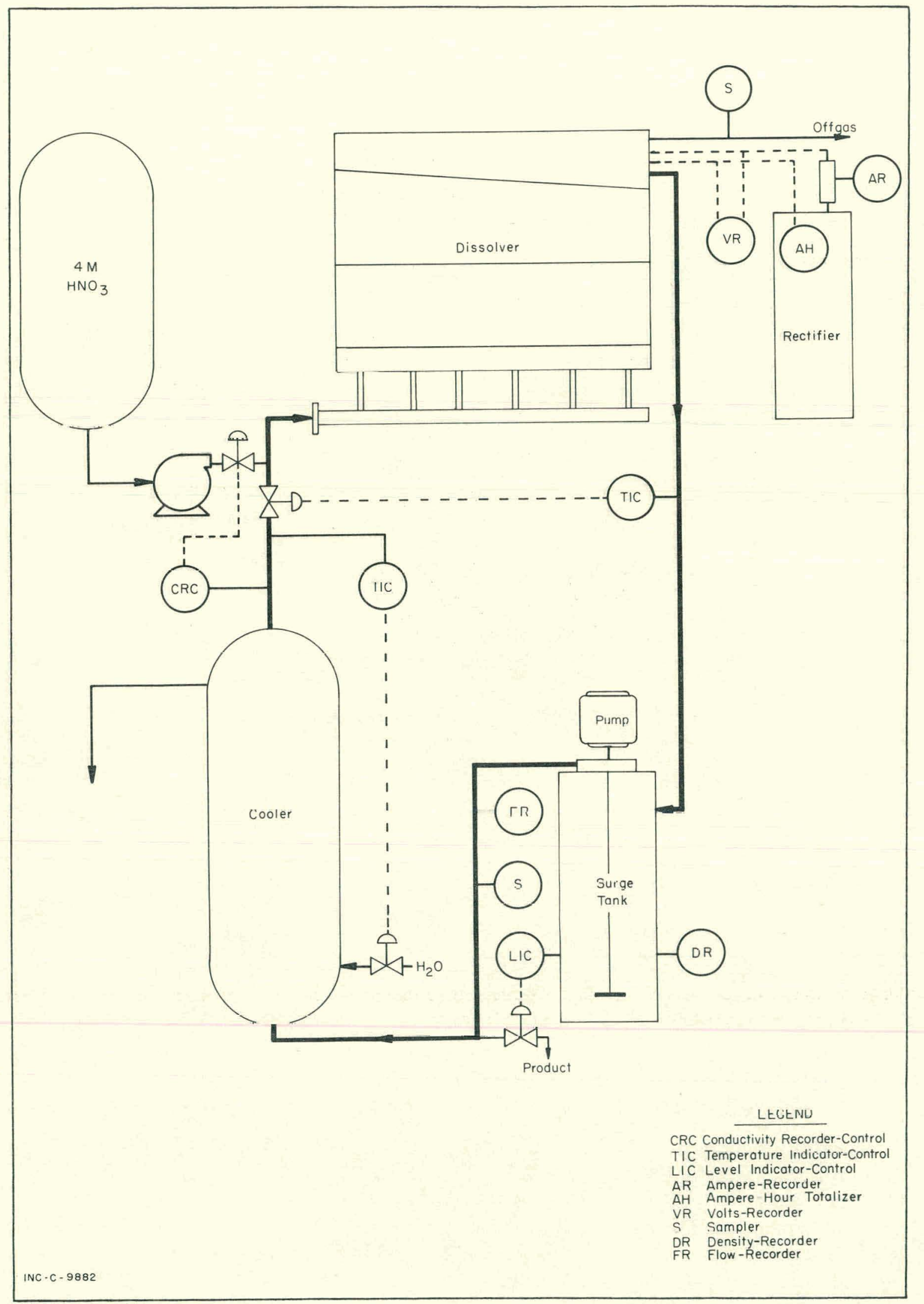

Fig. 7 Flow sheet of electrolytic dissolution system. 
4.2 Ammonium Bifluoride Process for Zirconium Clad Zirconium DioxideUranium Dioxide Fuels

(L. A. Decker, T. L. Evans; Chemistry Section)

Three distinctly different processes are being considered for fuels like the Zircaloy-clad zirconium dioxide-uranium dioxide fuel of the Shippingport PWR Core 2 seed 1 . One of these processes, described in this report, involves dissolution of the mixed oxide fuel core in fused ammontum bifluoride. A second process using a three-step aqueous dissolution flow sheet has been described previously and a third, a halide volatility process, is currently under study at Argonne National Laboratory in a cooperative program with Idaho Nuclear. Corporation. Upon completion of the Argonne studies, the three processes will be evaluated to select one for further development and installation at the ICPP.

Results of recent ICPP studies on the fused salt alternate are presented here. The fuel elements are composed of sintered wafers of enriched uranium dioxide (28 percent) and zirconium dioxide (72 percent), coated with pyrolytic graphite, and distributed in Zircaloy -4 fuel plates. These sintered oxide wafers are resistant to dissolution by the common fuel reprocessing solvents. Long exposure to high concentrations of fluoride ion at elevated temperatures eventually dissolves the wafers.

Anhydrous, fused ammonium bifluoride provides a system that is high in fluoride concentration ( $42 \mathrm{M})$ at a higher temperature than is possible with aqueous systems. The mixed zirconium dioxide-uranium dioxide in the wafers will dissolve in fused ammonium bifluoride at temperatures greater than $190^{\circ} \mathrm{C}$. A two-step aqueous-fused salt dissolution method is outlined in the flow sheet represented by Figure 8 .

4.21 Decladding. The Zircaloy -4 cladding dissolves rapidly and completely in $10 \mathrm{M}$ hydrofluric acid if the fluoride to zirconium mole ratio is 5 or higher. 13$]$. If the decladding solution is sufficiently low in uranium concentration, it could be sent directly to waste storage; otherwise, it would be combined with the product from the fused salt dissolution of the zirconium dioxide-uranium dioxide meat.

The Zircaloy -4 cladding is soluble in the fused salt but this would not be a desirable decladding method because the zirconium forms a thick slurry of ammonium fluozirconate, $\left(\mathrm{NH}_{4}\right)_{3} \mathrm{ZrF}_{7}$, at a slurry loading higher than two moles per liter, thus requiring a great excess of ammonium bifluoride just to dilute the slurry. The ammonium fluozirconate is soluble in aqueous systems along with the ammonium bifluoride, but the resulting solution is too high in fluoride ion concentration to allow practical solvent extraction of the uranium in the equipment at ICPP. Fortunately, the two-step dissolution method allows the use of the fused salt to dissolve the highly resistant oxides but avoids the problem of thick slurry and high fluoride concentration in the solvent extraction feed solution.

4.22 Dissolution. The dissolution of the zirconium dioxide-uranium dioxide wafers in fused ammonium bifluoride proceeds at $190^{\circ} \mathrm{C}$ at a rate high enough to process about five batches per day in one piece of equipment. Dissolution would be carried out in the same vessel as the decladding step after removing the aqueous hydrofluoric acid solution and raising the temperature of the vessel to the dissolution temperature.

The anhydrous dissolver product containing the uranium has a uranium 


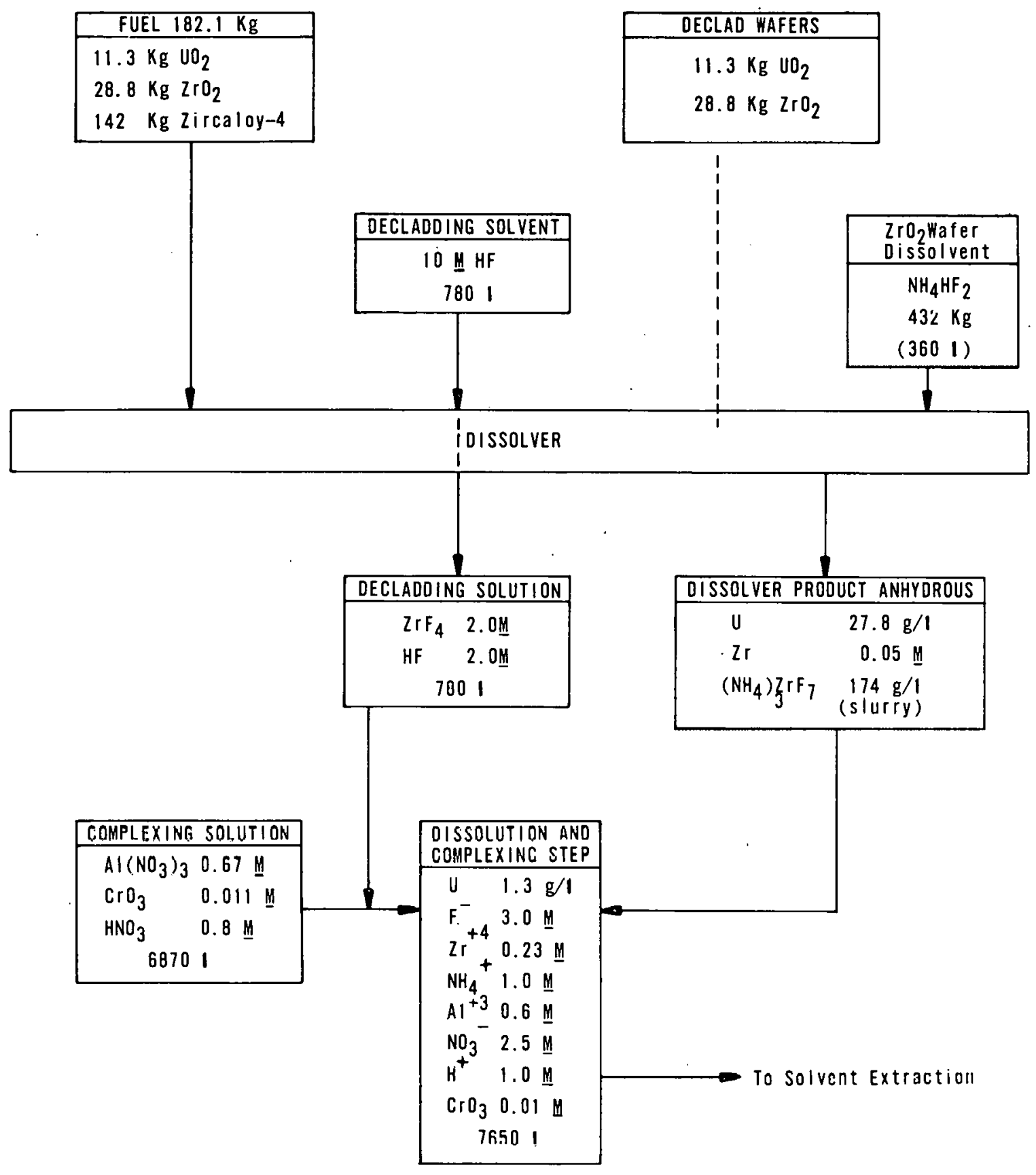

INC-B-11065

Fig. 8 Flow sheet for two-step aqueous-fused salt dissolution of advanced PWR fuel. 
solubility of about $37 \mathrm{~g} / 1000 \mathrm{~g}$ of solution (at $190^{\circ} \mathrm{C}$ ) as shown in Figure 9. Most of the zirconium from the zirconium dioxide will be present as the insoluble ammonium fluozirconate since the solubility of that compound in the anhydrous solution is about $0.10 \mathrm{~mole} / 1000 \mathrm{~g}$ at $190^{\circ} \mathrm{C}$ as shown in Figure 10 . The flow sheet calculations assumed a solubility of 0.05 mole/1000 $\mathrm{g}$ to allow for cooling to $150^{\circ} \mathrm{C}$ upon transferring to the adjustment vessel.

The corrosion data shown in Table VIII indicate that several materials could be used to contain the fused salt at a temperature of about $190^{\circ} \mathrm{C}$.

4.23 Adjustment. The anhydrous dissolver product containing the uranium can be dissolved and the fluoride complexed with a solution of aluminum nitrate. Chromic acid will rapidly dissolve the resulting uranium tetrafluoride by oxidizing the uranium to $U(V I)$. The proper acidity for rapid oxidation of uranium is obtained by adjusting with nitric acid. The complexed solution is then suitable for feed to the solvent extraction columns where the uranium is extracted with tributyl phosphate.

4.24 Conclusion. This two-step aqueous-fused salt process is proposed as a possible alternate to the three-step all aqueous process [12] but appears to have no advantage over the latter at present. Final selection of a process will await an evaluation study after a halide voltility process has also been studied. 


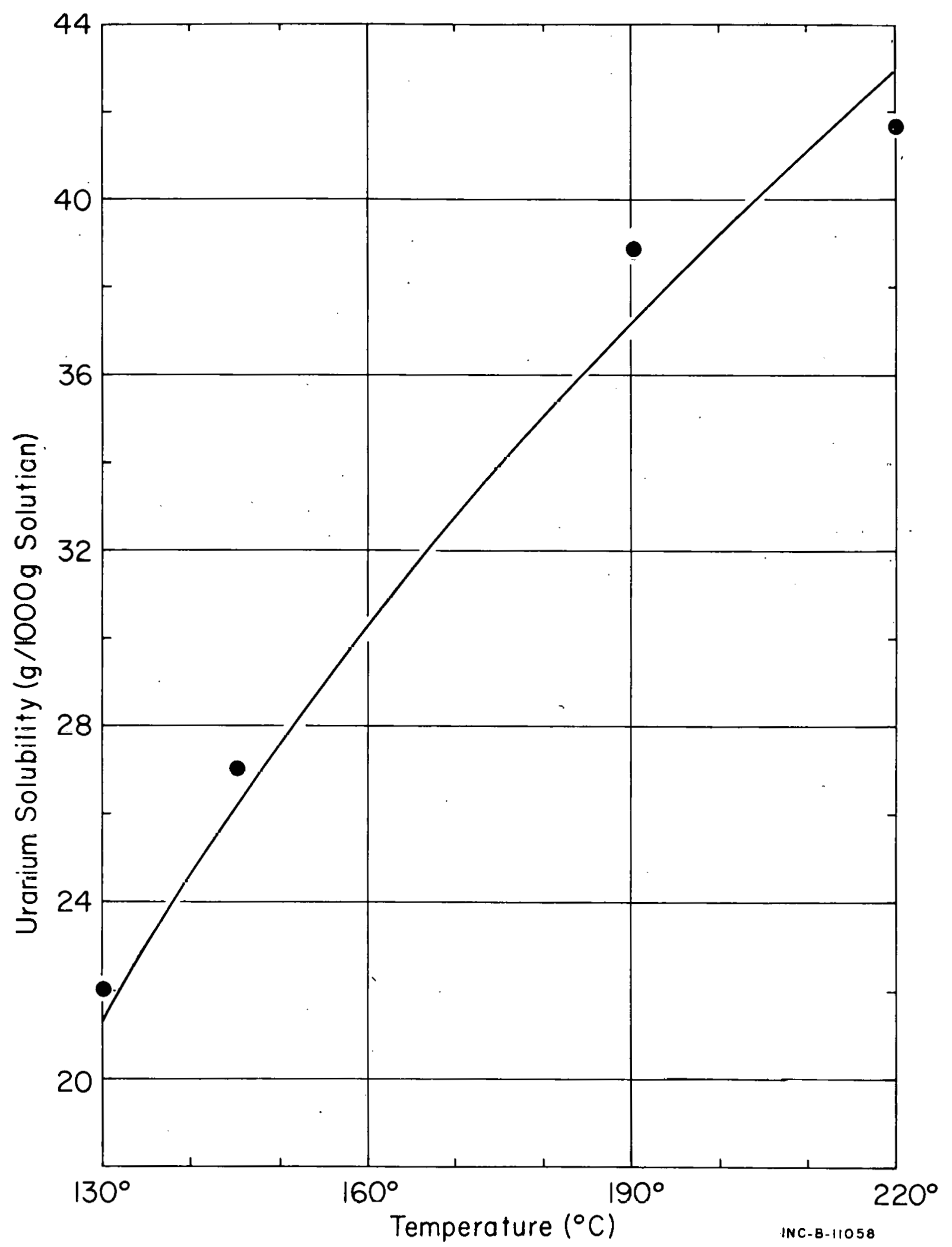

Fig. 9 Solubility of uranium in anhydrous $\mathrm{NH}_{4} \mathrm{HF}_{2}$ versus temperature. 


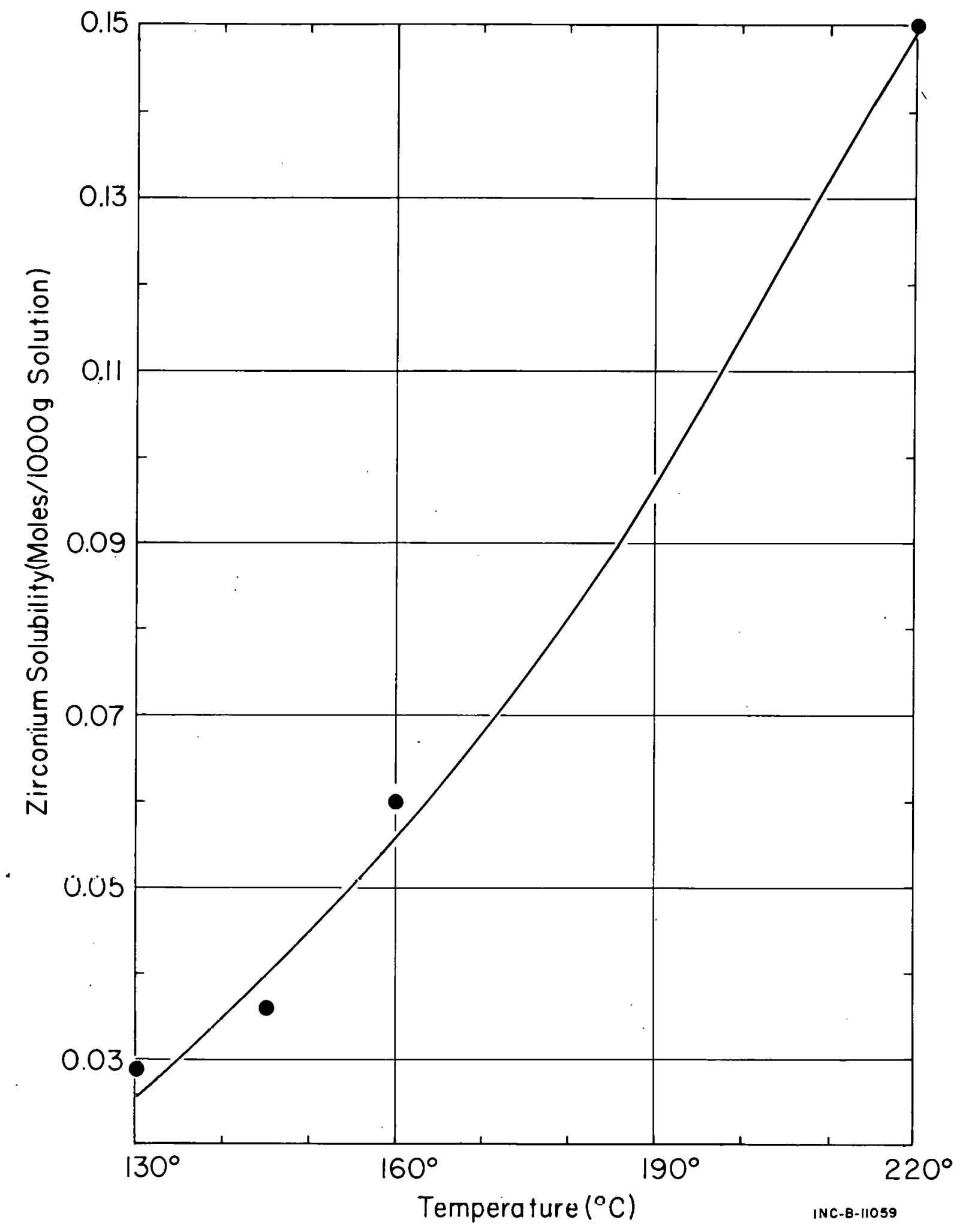

Fig. 10 Solubility of zirconlum in anhydrous $\mathrm{NH}_{4} \mathrm{HF}_{2}$ versus temperature. 
$\underline{\text { TABLE VIII }}$

CORROSION RATES FOR VARIOUS METALS IN FUSED AMMONIUM BIFLUORIDE

\begin{tabular}{lcc}
\hline \multicolumn{1}{c}{ Metal } & \multicolumn{3}{c}{$\begin{array}{c}\text { Corrosion Rate } \\
(\mathrm{mils} / \mathrm{mo})\end{array}$} \\
\cline { 2 - 3 } Carpenter-20 & $\frac{140^{\circ} \mathrm{C}}{1}$ & $190^{\circ} \mathrm{C}[14]$ \\
Monel & & 6.4 \\
Hasteloy C & & 3.2 \\
310 SS & & 5.7 \\
\hline
\end{tabular}

\subsection{Chemical Destruction of Dowex Resin (M. W. Wilding; Chemistry Section)}

Dowex 1-X4 resin used to recover $\mathrm{Np}-237$ or other radioisotopes from process streams can be completely dissolved in hot $\left(70\right.$ to $\left.90^{\circ} \mathrm{C}\right) 0.2 \mathrm{M} \mathrm{KMnO}$ $-2.0 \mathrm{M} \mathrm{HNO}_{3}$ solution for disposal when the useful life of the resin has been expended. The solution containing the dissolved Dowex resin can then be concentrated to half its original volume without the formation of precipitates. The resin would be dissolved so that it could be safely and easily pumped into waste storage tanks, thus eliminating many of the problems which could be encountered in disposal of the radioactive resin by other means.

Dow 1 x $1-\mathrm{X} 4$ resin was treāted in laboratory experiments with various concentrations of potassium permanganate, chromic acid, and nitric acid as shown in Table IX. Dissolution at $70^{\circ} \mathrm{C}$ in $0.2 \mathrm{M} \mathrm{KMnO}_{4}-2.0 \mathrm{M} \mathrm{HNO}_{3}$ was quite effective and only mildly corrosive (less that $\overline{2.0}$ mils per month) to austenitic stainless steels. One liter of this solution dissolved 40 grams of resin in eight hours. A low nitric acid concentration was purposely chosen to avoid the instability that has occurred at about $10 \mathrm{M}$ nitric acid ${ }^{[15]}$.

The solution containing the dissolved-resin was concentrated to about one half the original volume. The concentrated"solution was stable, but solids began to form as the evaporation continued. 
TABLE IX

TEST CONDITIONS AND RESULTS DURING TRIAL

DISSOLUTION OF DOWEX 1-X4 RESIN

\begin{tabular}{|c|c|c|c|c|c|}
\hline $\begin{array}{l}\text { Temp. } \\
\left({ }^{\circ} \mathrm{C}\right) \\
\end{array}$ & $\begin{array}{l}\text { Time } \\
\text { (Hours) } \\
\end{array}$ & $\begin{array}{l}\mathrm{CrO}_{3} \\
(\mathrm{M})^{2}\end{array}$ & $\begin{array}{c}\mathrm{KMnO}_{4} \\
(\mathrm{M}) \\
\end{array}$ & $\begin{array}{l}\mathrm{HNO}_{3} \\
(\mathrm{M}) \\
\end{array}$ & Observations \\
\hline 20 & 24 & 16 & & & Physically degraded but not dissolved \\
\hline 70 & 24 & 16 & & & Physically degraded but not dissolved \\
\hline 90 & 24 & 8 & & 2.0 & Physically degraded but not dissolved \\
\hline 20 & 24 & & 1.5 & & No apparent degradation \\
\hline 90 & 24 & & 1.5 & & No apparent degradation \\
\hline 20 & 24 & & 0.2 & 2.0 & No apparent degradation \\
\hline 90 & 6 & & 0.2 & 2.0 & Completely dissolved \\
\hline 90 & 8 & & 0.2 & 1.0 & Dissolved except for a trace of resin \\
\hline 70 & 8 & & 0.2 & 2.0 & Completely dissolved \\
\hline
\end{tabular}




\section{WASTE MANAGEMENT}

\section{THE IDAHO WASTE CALCINING FACILITY}

1.1 Operating Experience in the Current WCF Processing Campaign

(G. E. Lohse; Process Engineering Section)

(T. L. Hoffman; Chemistry Section)

The second processing campaign in the Waste Calcining Facility (WCF) was started in mid-March 1966, with nonradioactive simulated waste; and after equilibrium conditions were attained, radioactive waste was started to the calciner on April 1. In the succeeding 15 months, about 595,000 gallons of waste from three tanks have been converted to about 6,600 cublc feet of solids which are stored in permanent storage bins. Since initial operation of the WCF in late 1963, about 1.1 million gallons of highly radinartive waste havo boon reduced to solids. In general, operation of the facility continues to be excellent.

1.11 Operating Summary. During the second processing campaign, the average "on-stream" feed rate, as shown in Table $\mathrm{X}$, has been about 91 gallons per hour (14 percent above design), while the net rate has averaged about 65 gallons per hour. The on-stream time has been about 79 percent. During the last quarter of this period, the average net feed rate has been increased to nearly 78 gallons per hour by evaporation of the feed just prior to calcination. The release rate of ruthenium to the environment has averaged about 380

\section{TABLE X}

WASTE CALCINING FACILITY OPERATING SUMMARY -- RINN H-?

\begin{tabular}{lr}
\hline & $\begin{array}{r}\text { Run tin Date, } \\
\text { June } 30,1967\end{array}$ \\
Total operatine time, hrs & 10,950 \\
Operating time (with hot feed), hrs. & 8,610 \\
Net volume of waste calcined, gals. & 595,000 \\
Net volume liquid to blend tanks, gallons/hr & 65.4 \\
Gross liquid calcined, gallons/hr & 91.3 \\
Net volume solids to storage, ft3 & 6,590 \\
$\quad$ rrom hot operation & $3160-0.3$ \\
Kuthenlum release rate to stack, mCi/day & 380 \\
$\quad$ Maximum-Minimum &
\end{tabular}


millicuries per day and has ranged from 0.3 to $3160 \mathrm{mCi}$. The former value resulted during calcination of 15-year old waste, while the latter occurred during a temporary shutdown period with the ruthenium adsorbers on-stream. The established release limit for ruthenium is $52,000 \mathrm{mCl} /$ day. The release rate of strontium -90 has averaged about $0.2 \mathrm{mCl}$ /day and has ranged from 0.006 to $52 \mathrm{mCl}$. The strontium release exceeded one $\mathrm{mCl} /$ day on only 11 days during this campaign, and for 10 of these the higher releases resulted from excessive penetration through a defective off-gas filter. Normal release values were achieved merely by replacing the filter. The established release limit for strontium -90 is $2,600 \mathrm{mCi} /$ day.

Flexibility of the WCF for processing various types of waste was demonstrated as two separate types of wastes were fed to the calciner at alternate 18-hour intervals for a five-month period. One waste contained a high concentration of ammonium nitrate, while the second contained a sodium concentration about double that contained in other ICPP first-cycle wastes. This processing procedure was used to minimize the ammonium concentrations in the feed and off-gas scrubbing solutions. No process upsets resulted and pseudo-equilibrium conditions in the calciner and scrubbing systems were obtained. At present, the wastes from these two tanks have been combined in one vessel and the mixture. is being fed to the calciner.

Overall operation of the WCF has been satisfactory except for five unscheduled shutdowns due to leaks; there were additional minor problems not involving shutdowns, with the feed control system, the ruthenium adsorbers, and the final filters. Four of the shutdowns were caused by leaks in the NaK heating system and are discussed in Sections II-1.2 and -1.3. The other leak, in the solids transport system, and problems encountered with feed control, adsorbers, and final filters are discussed below. All problems except for NaK or solids leaks encountered during WCF processing were solved without calciner shutdown.

1.12 Solids Transport Abrasion. Two leaks in the solids transport system have occurred since the beginning of the second WCF campaign. In neither case was any air-borne activity released from the process cells or filter system. The first leak was discovered after the calciner was shut down in September 1966 because of a NaK leak in the tube bundle of the calciner NaK heat exchanger. The solids leak was located in one of the two product takeoff lines, and an estimated 12 cubic feet of solids were discovered on the calciner cell floor. Removal was accomplished by a combination of pushing with a longhandled scraper and water flushing the solids to a floor drain, and alsu by dissolving part of them with nitric acid. The leak was attributed to the abrasive action of the alumina product on certain sections of the pipe.

The second leak also occurred in the same product line, but was located closer to the calciner in a fitting at the junction of the solids removal control air and product takeoff lines. About two cubic feet of solids were discovered on the floor in a routine daily inspection, and were removed in a similar manner to that described above. Misalignment in the fitting presumably caused severe abrasive action. The second product takeoff line was removed and inspected, but abrasive action on this line, which was constructed properly, was minimal. Selected sections of the piping (Types 304L and 347 stainless steel) were replaced with heavier wall piping or with Type $17-4 \mathrm{PH}$ stainless steel, heat treated to $\mathrm{R}_{\mathrm{C}} 40$ hardness. 
1.13 Feed Control. Considerable feed control problems associated with plugging of feed lines, valves, and nozzles were experienced during the initial months of the campaign [1]. One nozzle plugged completely on May 15, 1966, and remained plugged until the unscheduled shutdown in September. The plugging was attributed to silica gel which collected in the feed evaporator and then collected at the electrodes of the flowmeter as the liquid was fed to the calciner. The feed rates to the other two nozzles were increased, and the overall feed rate continued to be over 10 percent above design.

A second nozzle plugged on June 14, 1966, and remained plugged for seven days. Surprisingly, the calciner operated well with the one remaining nozzle, and a feed rate of 71 gallons per hour was maintained. The versatility of the WCF to continue to operate at satisfactory rates with only one nozzle was adequately demonstrated. At no time was the calciner operation shut down, or slowed appreciably, due to feed line plugging.

1.14 Adsorber Operation. Four large beds of silica gel containing 6300 pounds each are installed in parallel to adsorh ruthenium from the WCF offgao. The adsurbers continued to keep ruthenium release rates at an average of $380 \mathrm{mCi} /$ day, well below the maximum allowable limit. Fluclualions in the rutlienlum release were frequently observed, and these were caused by alternate processing of different wastes or by unscheduled shutdowns during which feed to the calciner was shut off. At one time an abrupt increase in the ruthenium release rate was attributed to breakthrough of ruthenium from one of the adsorbers. This adsorber was taken off stream, and the ruthenium release rate decreased immediately. After regeneration of the silica gel, the adsorber was placed back on stream and the ruthenium release remained low.

1.15 Final Filter Operation in Presence of Ammonium Nitrate. Early in July 1966, while processing aluminum nitrate waste containing a high concentration of ammonium ion, the prcssure drop across the final filters increased about 4 inches, to 10:5 inches of water, during a four-day period of operation. The off-gas filters were replaced, and ammonium-free wastc was starled into the WCF becuuse it was belleved that the rapid rise in pressure drop was related to the ammonium waste. However, a rapid pressure drop rise occurred with the new filters until the temperature of the off-gas entering the filters was decreased from 85 to $80^{\circ} \mathrm{C}$. After the temperature change, a dramatic four-inch decrease in pressure drop across the filters was observed. An analysis of the operation indicates that trace quantities of ammonlum nftrate ffirst from the waste during calcination and later -- whlle ammonium-free waste was being calcined -- from residual material in the calciner, scrubbing system, and/or silica gel absorbers in the off-gas train) may deposit on the filters and form crystals to partially plug the filter gas passages. The connection between temperature and pressure drop could be due to a temperature effect on the size of ammonium nitrate crystals. At $84.5^{\circ} \mathrm{C}$, a marked change occurs in dimensions of ammonium nitrate crystals.

1.16 Packless Valve Fallures. Considerable corrosion occurred on the discs and welds of the Type 348 stainless steel bellows of valves that were removed from the feed system for repair. An inspection of the bellows of one of these packless valves revealed that transgranular stress corrosion cracking, intergranular attack, pitting, and cyclic fatigue had occurred. Both mechanical and corrosive conditions contributed to the metallic disintegration. 
The operating experience to date indicates an approximate service life of nine months in nitric acid feed solutions. This is similar to earlier experience with this type valve[16]. Although thicker discs and welds will increase the service life with respect to corrosion, a light gauge material is required to obtain the mechanical characteristics required for the successful operation of bellows-seal valves.

\subsection{NaK Heating Problems in the Current WCF Campaign}

(G. E. Lohse; Process Engineering Section)

The heat required for the decomposition of the calciner feed is supplied through an indirect heat transfer system which uses an eutectic liquid metal $(\mathrm{NaK})$ to transfer heat from an oil-fired radiant heater to the fluidized bed. Details of this system are presented elsewhere [17]. The material of construction of this system is primarily Type 316 stainless steel, which was selected over other austenitic steels because of its greater initial strength at elevated temperatures.

Performance of this NaK heat transfer system generally has been satisfactory. However, most of the unscheduled calciner shutdowns to date have occurred because of fallure of liquild metal system components and piping. Operation of the system was first begun in 1961; up to June 1967, there had been 44 startups from room temperature, about 1300 hours of operation below $600^{\circ} \mathrm{C}$, and over 20,000 /hours of operation above $600^{\circ} \mathrm{C}$. Over 75 percent of the operating time has been accumulated during operation of the WCF with radioactive feed. During the first processing campaign (about 7600 operating hours), two NaK leaks which occurred from the same fitting (a riser from the NaK header to an expansion tank) located in a nonradioactive portion of the facility were responsible for 51 of 57 hours of downtime. Details of these failures are described in IDO-14662 [18].

In the second (current) WCF processing campaign, four additional failures in the NaK system have caused shutdown for repair or replacement of components. The first of these occurred after 3542 hours of operation $(16,200$ accumulative hours) from the same area, ie, the riser to the expansion tank, as the leaks in the first campaign. This time the riser was changed from 1-1/2- to 3-inch pipe and a flexible connection was installed in the hellum line at the top of the expansion tank to reduce stress levels. Operation was resumed and continued for 800 hours until a fatlure of the field cotls on the NaK pump forced a second shutdown. During a testing period to confirm. the NaK pump fallure, a NaK leak from the heat exchanger inner-tube area to the helium monitoring chamber [17] was also discovered. This, along with maintenance on other WCF components exclusive of the $\mathrm{NaK}$ system, required a shutdown of about two months. Satisfactory repair of the NaK pump was achieved merely by replacing the field coils, but restoration of the heat exchanger to its original integrity was not attempted after it was determined that operation without the hellum monitor was practical and did not introduce any undue hazard.

The fluidized bed heat exchanger, as originally designed [17], consisted of 42 bayonet tubes each having a hellum filled annulus between the NaK-containing tubes and the outer heavy walled jacket tube. Changes in pressure in the helium chamber were intended to indicate any leakage in tube walls. Except for fallure of both a NaK tube and a hellum jacket tube, it is not possible for NaK to leak into the fluidized bed. 
Previously, calculations reported in the WCF Safety Analysis [17] indicated that $\mathrm{NaK}$ leak rates up to one gallon per minute would not even noticeably increase the temperature of the fluidized bed. On the other hand, NaK leak rates of 14.8 gallons per minute or greater would cause a rapid increase in the bed temperature, and this effect would constitute a means of discovery of large NaK leaks. However, complete severance of a tube would be necessary for large leaks.

A comprehensive review of the system at the time of the second failure indicated that the consequences of a NaK leak into the calciner were unchanged, and only the detection capabilities for small NaK leaks were affected. To compensate for loss of the helium monitor for detecting small leaks, a continuous level recorder with appropriate alarms was incorporated in the NaK expansion tank to alert operating personnel of changes in the volume of NaK in the circulating loop. Additionally, analysis of bed and scrubbing solution samples for potassium (present in the feed only in very low concentrations) permits detection of $\mathrm{NaK}$ leaks as low as $100 \mathrm{cc} / \mathrm{hr}$. 'Thus, small NaK leaks can be detested before they become serious. Further reviow indlcated that the tensile strength of the Type 316 stainless steel samples removed from the system was very near that of new metal, and, because the oiter helium jacketing tubes have twice the wall thickness of the inner NaK return tubes, the tubes were considered strong enough to contain $\mathrm{NaK}$ at all operating temperatures. Therefore, the decision was reached to continue operation of the facility without repair of the heat exchanger. The hellum monitoring chamber was isolated from the helium blanketing supply and a new drain was installed from the chamber to an existing NaK drain line.

Following this shutdown, the system was operated satisfactorily for 3050 hours before a NaK leak occurred from one of the drain lines for the main NaK piping. Another brief shutdown was required to replaoe a damigged fitting in the immediate vicinity of the leak. After about 1000 hours, the fourth failure was detected from the NaK pump tube. The pump was removed from the system, rebuilt with available spare parts, and reinstalled. Currently the NaK system is functioning smoothly and no serious problems are anticipated, Resulte of metallurgical examination of components removed from the NaK piping are presented in Section II-1.3, following.

\subsection{Effect of NaK on Stainless Steel Piping in the WCF Heat Exchange System} (T. L. Hoffman; Chemistry Section)

Stainless steel, Type 316, was selected as the material of construction for the vessels and lines in the $\mathrm{NaK}$ heat transfer system of the Waste Calcining Faoility luevause of its tensile strength at elevated temperatures and its resistance to $\mathrm{NaK}$ and nitrate vapors at elevated temperatures. At the time this choice had to be made there were no data on the net effect of inng-term expusure of 'Type 316 stainless ateel to $\mathrm{NaK}$ at 600 to $750^{\circ} \mathrm{C}$. Today, with greater than 20,000 hours operating time on the NaK loop of the WCF, this system has had more time at elevated temperatures than any other known operational or test loop and, therefore, represents a valuable source for information on the response of this material to NaK at elevated temperatures. In general, the material has performed very well although id specific limitation has now been defined by experience. This is a susceptibility to failure by brittle fracture under applied stress. This dictates careful arrangement of vessels in the loop and requires thorough design analysis of the supporting structures. 
The liquid metal in this sytem is the sodium-potassium eutectic alloy, $22.8 \mathrm{wt} \% \mathrm{Na}-78.2 \mathrm{wt} \% \mathrm{~K}$. Most of the operating time on the loop has been in the temperature range 600 to $700^{\circ} \mathrm{C}$ with 44 starts from room temperature. During steady operation the oxygen content of the NaK has been maintained below $50 \mathrm{ppm}$.

1.31 Evaluation of Piping From the Hotter Portion of the Loop. A service test examination was conducted on a portion of line that was installed upstream from the NaK heater in the ICPP Waste Calcining Facility. This three-inch Schedule 40 pipe was in NaK service for 1,118 hours below $600^{\circ} \mathrm{C}$ and 15,174 hours above $600^{\circ} \mathrm{C}$, and had undergone 37 starts from room temperature without failure.

The test piece was cutfrom the loop so as to include a custom-made wrought tee fitting having 0.55 -inch-thick walls that were welded into the piping. The overall length of the specimen, which included the pipe and tee, was 33 inches.

A metallographic examination of the piping and weld joints in the assembly indicated carbide precipitation at the grain boundaries and concentrations of up to 11 percent sigma phase (hard intermetallic compound of the general formula FeCr), as shown in Figures 11 and 12. A band of decarburized material 1 to 2 mils thick was found on the NaK side of the pipe wall (Figure 13). An 0.2to 0.3 -mil-thick porous oxidation film was observed on the outer surface of the pipe wall (Figure 14). This film was only partially soluble in boiling nitric acid and was magnetic.

The averages of duplicate analyses for carbon and nickel were 0.03 and 12.6 percent, respectively, on 5-mil-deep turnings from the inside of the pipe, and 0.09 and 13.2 percent, respectively, on similar turnings from the outside surface of the Type 316 pipe. General corrosion damage on the specimen after this 16,292-hour service was nil.

From X-ray diffraction studies, the presence of sigma phase was confirmed as a constituent in the NaK exposed piping. Carbide phases that were present in the NaK-exposed piping were not extracted or identified. The results of ASTM A262 tests, "Boiling Nitric Acid Test for Corrosion-Resisting Steels", on piping that had been exposed for 16,292 hours are recorded in Table XI. The corrosion rates increased with time on piping that had had 5 mils removed from the inside and outside surfaces, so that, at the end of the third period, the rate was 2.7 mils per month. On the other hand, piping that was tested before the inside and outside surfaces were removed suffered more than $10 \mathrm{mpm}$ corrosion. After the tests, intergranular attack was observed on the piping.

The mechanical properties of the three-inch test pipe at $20^{\circ} \mathrm{C}$ and at $760^{\circ} \mathrm{C}$ in air are recorded in Table XII. The observed tensile and yield strengths compare favorably with published values for unexposed Type 316 stainless steel. However, the observed average elongation percentages of the exposed pipe were 46 percent and 63 percent lower than the average of the published values at 20 and $760^{\circ} \mathrm{C}$, respectively. Izod impact test results show that pipe specimens which had been in NaK service absorbed 65 percent less kinetic energy in breaking than similarly tested specimens from unexposed pipe. 


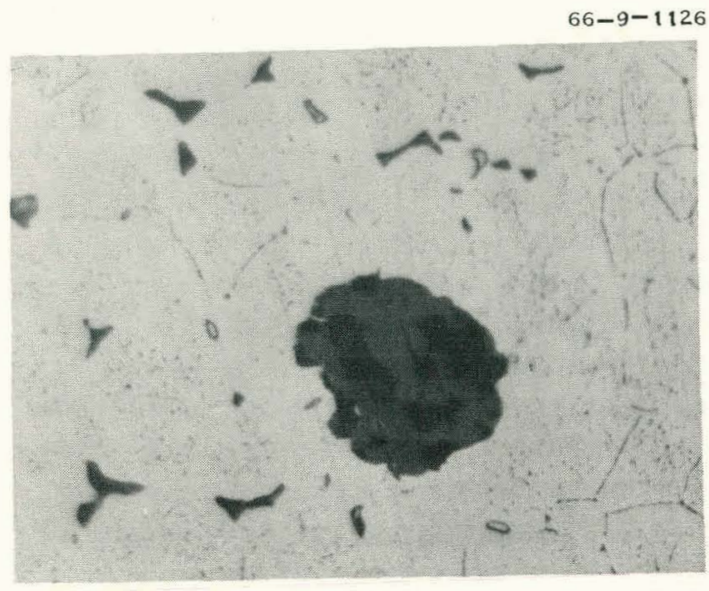

$10 \%$ OXALIC ACID ETCH

$750 \times$

F'ig. 11 Sigma particle in X-Section of 3inch schedule 40 Type 316 SS pipe after 15,000 hours at $760^{\circ} \mathrm{C}$.*

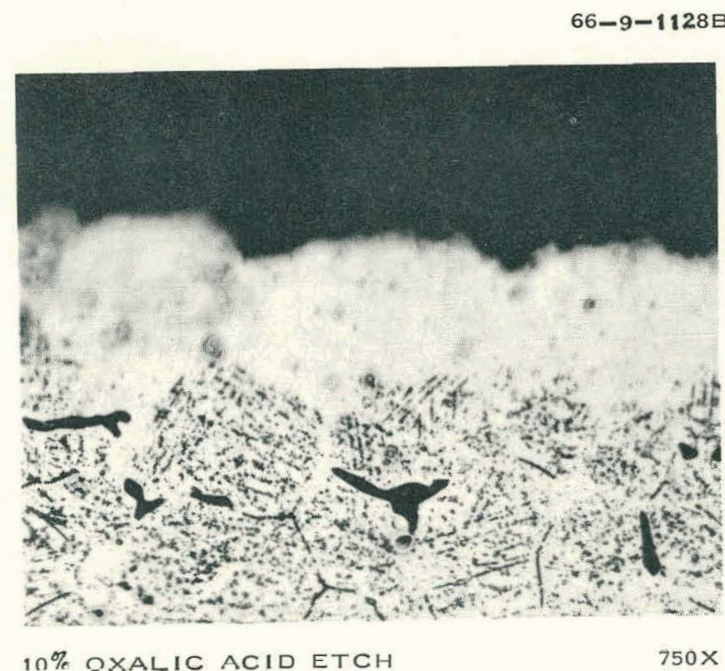

Fig. 13 Decarhurized zone of inside edge of 3 -inch Schedule 40 Type 316 SS pipe after 15,000 hours at $760^{\circ} \mathrm{C}$. *

\footnotetext{
* photo reduced one third in size.
}

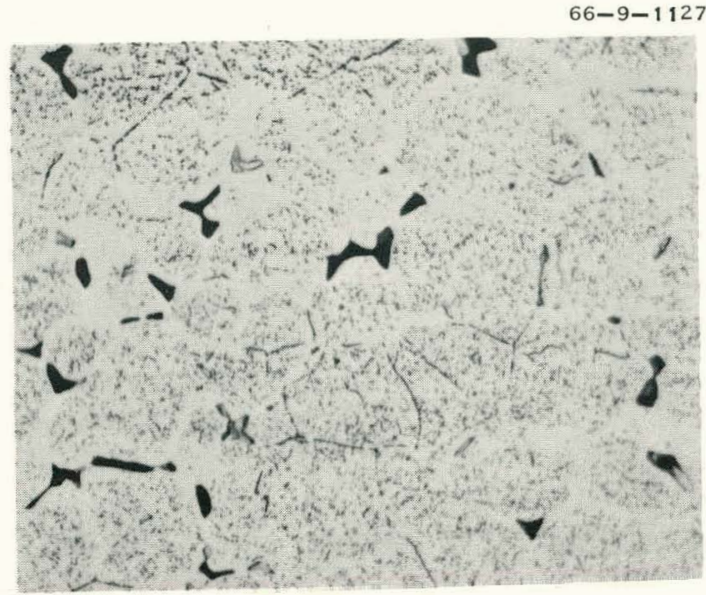

$10 \%$ ORALIL ACIB ETCH

$750 \times$

Fig. 12 Cross seculiun of 3 -1nch schedule 40 Type 316 SS pipe after 15,000 hours at $760^{\circ} \mathrm{C}$ *

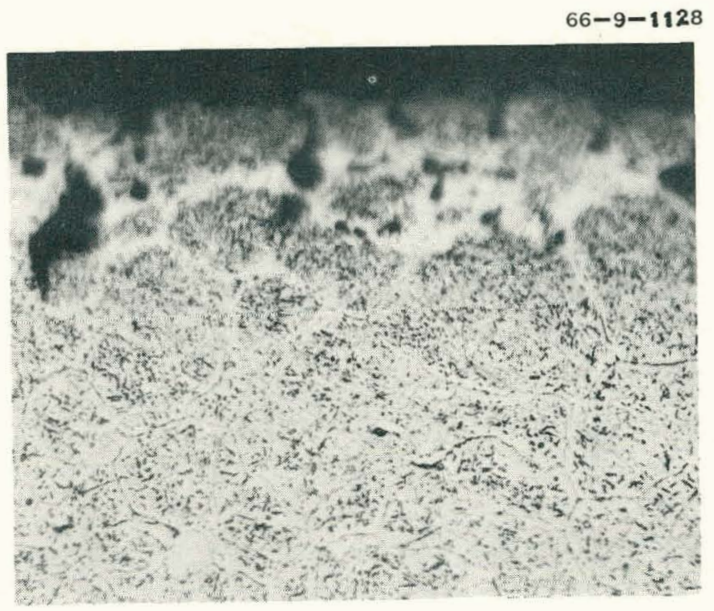

$10 \%$ OXALIC ACID ETCH

$750 \times$

Fig. 11 Outaide, or als side, of 3-inch Schedule 40 Type 316 SS pipe after 15,000 hours at $760^{\circ} \mathrm{C} . *$ 
TABLE XI

CORROSION OF WROUGHT TYPE 316 STAINLESS STEEL PIPE IN BOILING

65 PERCENT NITRIC ACID AFTER 16,292. HOURS SERVICE IN NaK al $760^{\circ} \mathrm{C}$

\begin{tabular}{|c|c|c|c|c|c|}
\hline \multirow[b]{2}{*}{ Specimen } & \multicolumn{4}{|c|}{$\begin{array}{c}\text { Penetration mpm } \\
\text { ( } 8 \mathrm{Hr} \text { Test Periods) }\end{array}$} & \multirow{2}{*}{$\begin{array}{c}\text { Intergranular } \\
\text { Attack } \\
\end{array}$} \\
\hline & 1 & 2 & 3 & Average & \\
\hline $\begin{array}{l}\text { Before Removal of } \\
\text { Inside and Outside } \\
\text { Surfaces }\end{array}$ & 14.0 & 10.2 & 10.6 & 11.6 & Severe \\
\hline $\begin{array}{l}\text { After Removal of } \\
\text { Inside and Outside } \\
\text { Surfaces }\end{array}$ & 1.1 & 1.5 & 2.7 & 1.8 & Mild \\
\hline
\end{tabular}

TABLE XII

MECHANICAL PROPERTIES OF TYPE 316 STAINLESS STEEL BEFORE AND AFTER EXPOSURE TO HIGH TEMPERATURE NaK

Published Values

(no $\mathrm{NaK}$ service)

at $20^{\circ} \mathrm{C}$

at $760^{\circ} \mathrm{C}$

Measured Values

(after 16,292

Hours in NaK Service)

at $20^{\circ} \mathrm{C}$

at $760^{\circ} \mathrm{C}$

Unexposed Tests

at $20^{\circ} \mathrm{C}$

Yield Strength
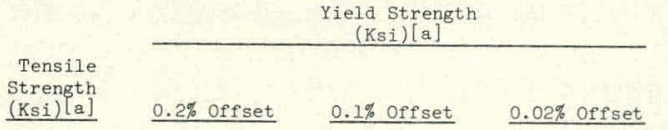

Elongation
in 2 inches

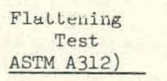

Subsize

$\begin{array}{ll}\% & \text { Izod Impact } \\ \text { (Ft-1b.) }\end{array}$

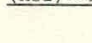

\section{$28-55^{[b]}$}

$25-42^{[c]}$

$21-42^{[c]}$

$40-70^{[\mathrm{b}]}$

Satisfactory

${ }_{N A}^{[a]}$

$30-45$

$19-30^{[b]}$

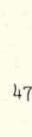

47

28

30

Failed

3.6

15

$14-16$

Satisfactory

10.2

[a] Kilo pounds per square inch.

[b] ASM Handbook, Vol. 1, 8th Ed., page 504.

c] The Elevated Temperature Properties of Stainless Steels, ASTM Data Service Publication DS 5-51, December 1965.

[d] There are no published values since this is not a standard test.

The exposed pipe broke completely into two halves during an ASTM A 312 flattening test, when flattening was continued until the opposite walls of the pipe met. On an unexposed pipe section, flattening was continued until opposite walls of the pipe met without producing cracks that could be observed at $15 \mathrm{X}$ in the section.

The hardness survey showed that the wrought pipe had diamond pyramid hardness numbers (DPH) that ranged from 150 to 180, which correspond to 79 
$R_{b}$ and $87 R_{b}$, respectively. Welds had a hardness of 130 DPH which correspond to $71 \mathrm{R}_{\mathrm{b}}$. These values are within the published range of values for unexposed Type 316 stainless steel.

1.32 Evaluation of Expansion Tank Connector Failures. Two service failures have occurred at the welds joining the pipe tee connectors and the nozzles of the NaK expansion tanks. Type 316 stainless steel was the material of construction of the weld deposits, nozzles, and connectors. Service time for one joint was approximately 3240 hours at 600 to $760^{\circ} \mathrm{C}$, and about 360 hours below $600^{\circ} \mathrm{C}$ 。 There were four startups from room temperature. The other joint experienced 39 startups from room temperature with 15,800 hours of operation between 600 and $760^{\circ} \mathrm{C}$ and 1150 hours below $600^{\circ} \mathrm{C}$.

During the post-failure examinations of these joints, cracks were observed in welds; in addition, the piping which was exposed for 17,000 hours $(15,800$ at 600 to $760^{\circ} \mathrm{C}$ ) cracked (Figure 15). Cracks in the weld were propagated both transgranularly and intergranularly (Figure 16). Notches which are sites for lucal stress raisers were found in each of these weld structures.

Neither sigma phase nor carhine precipitation was fuund on either the wrought piping or the cast weld deposit of the joint that was exposed for 3600 hours. Electron microscope fractographs of this weld are typified by the classic striations or crack front arrest lines shown in Figure 17. This fatigue failure appeared to be caused by multi-cycle, low stress forces.

On the weld that was in service for 17,000 hours, sigma phase and carbide precipitation were observed at the grain boundaries. Eight crack front arrest lines were observed on a fractured surface at 30 diameters. Because of the number and width of these fatigue striations, the cyclic stress undoubtedly resulted from the thermal stresses that were imposed on the system during the 39 startups. The topography of the fractured welds surface is shown in Figure 18.

1.33 Evaluation of a NaK Drain Line Fitting Failure. A service failure occurred at a weld loining a fnrged conocntric reducer lo the drain pipe for the main NaK loop. Type 316 stainless steel was the material of construction on this forging, weld deposit, and pipe. Service time on this forging was 19,200 hours at 600 to $760^{\circ} \mathrm{C}$ and 1300 hours below $600^{\circ} \mathrm{C}$. There were 43 startups from room temperature.

The postfailure examination showed that both the weld and reducer were cracked, accompanied by perforations in the weld area and the wall of the forged reducer. Cracks in the reducer were difficult to classify; these propagated both transgranularly and intergranularly.

A band of decarburization was observed on the NaK side of the reducer. Sigma phase and carbide precipitation at the grain boundaries were found in cross sections of the weld deposit and reducer. Electron microscope fractographs of the fracture in the weld are typified by elongated shaped dimples. These data suggest that shearing forces were imposed upon the weld, causing a ductile fracture. Fractographs of the fracture in the forged reducer suggest ductile tearing as in the weld fracture, but this observation is confused by a fracture profile which is a cleavage-type brittle fatigue fracture. 


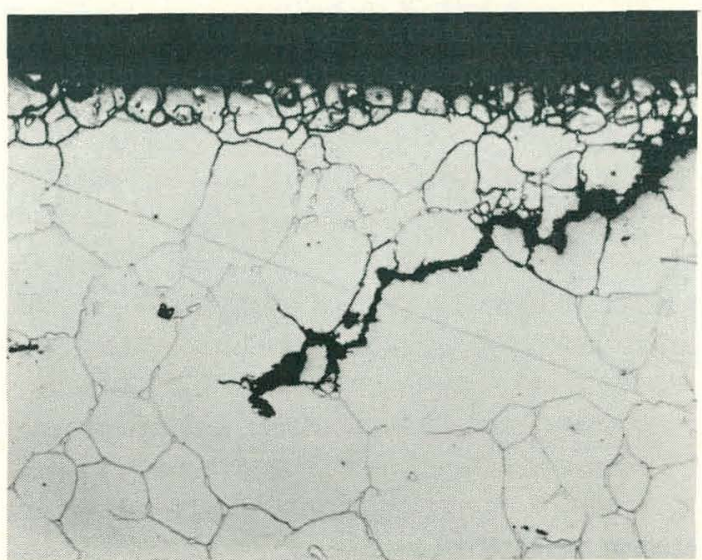

45-SECOND VILELLA'S ETCH

$500 x$

Fig. 15 Crack on inside of pipe tee connector after 15,800 hours at 600 to $760^{\circ} \mathrm{C}$.

MTR(REML) 639-2

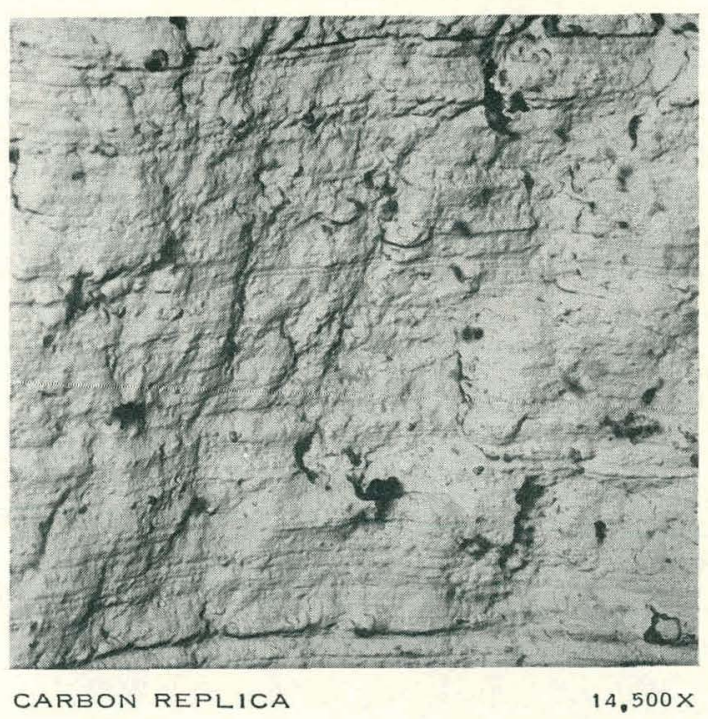

Fig. 17 Surface topography of nozzle-connertor weld failure after 3,240 hours at 600 to $760^{\circ} \mathrm{C}$, showing crack front arrest lines.*

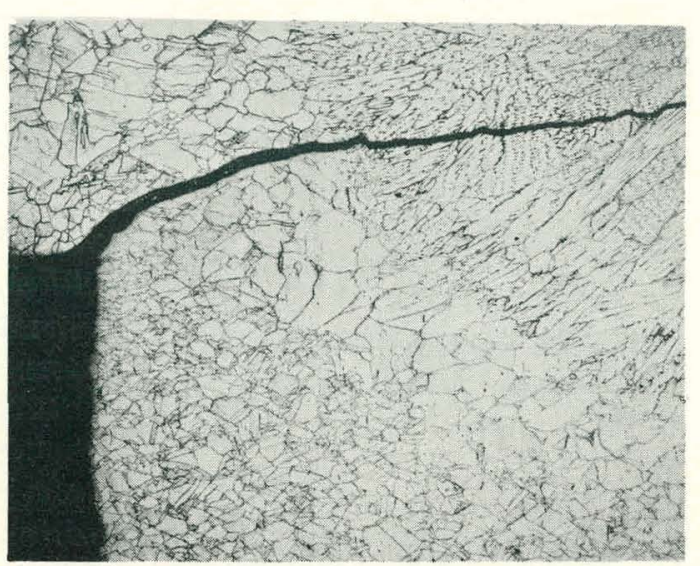

$10 \%$ OXALIC ETCH

$50 \times$

Fig. 16 NaK expansion tank weld failure after 3,240 hours at 600 to $760^{\circ} \mathrm{C}$.*

MTR (REML) 644-5

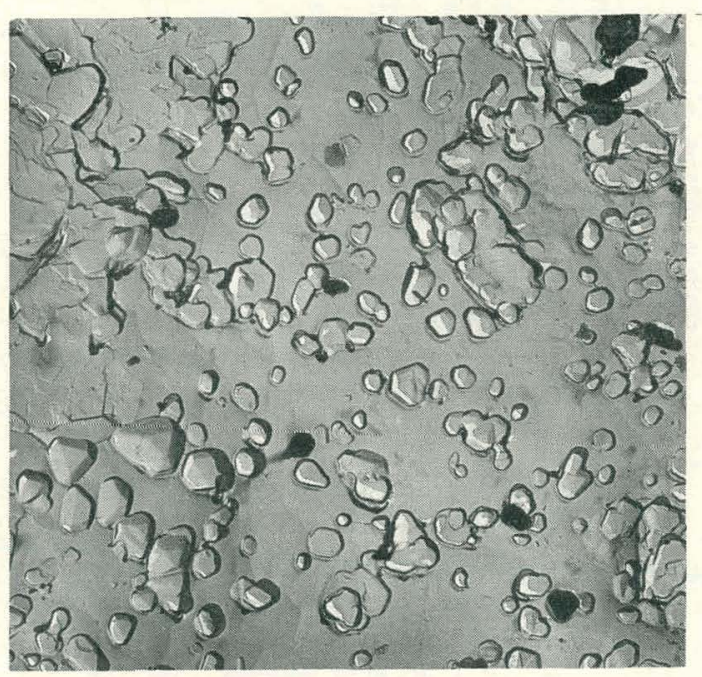

CARBON REPLICA

$14,400 \times$

Fig. 18 Surface topography of weld failure after 15,800 hours at 600 to $760^{\circ} \mathrm{C}$, showing uniformly distributed faceted particles. Striations are absent.*

* photo reduced one third in size. 
1.34 Conclusions. Most, if not all, of the failures in the Type 316 alloy in the WCF have been associated with brittle fractures in forged fittings or transition pieces where extra working had been done on the material. Apparently, the residual stress from this working plus the applied stress placed on the structure in thermal cycling has led to the failures. Information accumulated at this site since 1959 indicates that Type 304 L stainless steel, in room temperature tests, has twice the impact resistance of Type 316 stainless steel after 10,000 hours exposure to $\mathrm{NaK}$ at $650^{\circ} \mathrm{C}$. However, because the tensile strength is lower and no practical experience with Type $304 \mathrm{~L}$ steel at WCF operating conditions has been obtained, extensive experimental evaluation would be required before a NaK loop of Type 304L steel could be designed with confidence. Thus, although there have been an undesirable number of failures in the Type 316 steel in the NaK loop, a material of construction superior to Type 316 steel has not yet been proved. An alternate method of heating the WCF calciner, or less demanding operating conditions for the NaK loop, is highly desirable to ensure uninterrupted operation.

\section{ADVANCED WASTE CAT,CINATION STUDIF.S}

\subsection{Pilot Plant Calcination of Zirconium-Hydrofluoric Acid Wastes} (S. J. Horn, T. K. Thompson; Development Engineering Section)

A 212-hour run was made in the 12-inch-diameter pilot plant calciner to study the calcination of simulated zirconium-hydrofluoric acid waste, complexed with calcium nitrate. Steady state operation was achieved, and results indicate that this type of waste can be successfully calcined at $400^{\circ} \mathrm{C}$ if a $\mathrm{Ca} / \mathrm{F}$ mole ratio of at least 0.55 is maintained in the waste feed.

The 12-inch-diameter pilot plant calciner differs from the Waste Calcining Facility in that the primary cyclone for separation of fines from the off-gas is followed by a venturi scrubber and a condenser while the Waste Calcining Facility has a quench spray tower followed by a venturi scrubber and no condenser. Also, the Waste Calcining Facility off-gas requires additinnal cleanup in the form of silica gel beds to relluve $\mathrm{KuU}_{4}$ and absolute filters to remove the last traces of fines; the pilot unit does not handle radioactive material and thus does not require this final cleanup equipment.

The feedstock for the run was a zirconium-hydrofluoric acid solution simulating the waste obtained from processing of zirconium-based fuels, blended with accumulated off-gas scrubbing solution in a feed-to-scrub volumetric ratio of three to one. A calcium nitrate solution was added to complex the fluoride ion in a $\mathrm{Ca} / \mathrm{F}$ mole ratio of 0.55 . The resulting feedstock was a slurry containing a finely divided, calcium fluozirconate precipitate. Average fced compositions are shown in Table XIII.

Operating conditions for this experiment are shown in Table XIV. A 70hour period of steady state operation was achieved for all operating parameters with the exception of scrubbing system compositions and the mass median particle diameter, which tended to oscillate throughout the run. However, the particle size could be changed by adjusting the relative flow rates of air and waste to the atomizing nozzle. A material balance over the 70 hours of steady state operation was within two percent of the theoretical calculations. The 
TABLE XIII

AVERAGE FEED COMPOSITION OF SIMULATED ZIRCONIUM WASTE

\begin{tabular}{|c|c|c|}
\hline In Solution: & & \\
\hline $\mathrm{H}^{+}(\underline{\underline{N}} \mathbf{a})$ & & 1.40 \\
\hline $\operatorname{Zr}(\underline{M})$ & & 0.073 \\
\hline Al $(\underline{M})$ & & 0.314 \\
\hline $\mathrm{NO}_{w}(\underline{\mathrm{M}})$ & & 3.80 \\
\hline $\mathrm{Ca}(\mathrm{g} / 1)$ & & 29.60 \\
\hline $\mathrm{F}^{-}(\mathrm{g} / \mathrm{I})$ & & 14.05 \\
\hline $\operatorname{Cr}(g / 1)$ & & 0.396 \\
\hline $\mathrm{B}(\mathrm{B} / \mathrm{1})$ & & 1.08 \\
\hline $\operatorname{Sn}(g / 1)$ & less than & .0 .015 \\
\hline \multicolumn{3}{|l|}{ In Solids: } \\
\hline $\operatorname{Zr}(w t \%)$ & & 31.2 \\
\hline $\mathrm{Ca}(w \mathrm{t} \%)$ & & 14.1 \\
\hline F (wt\%) & & 31.25 \\
\hline Al $(w t \%)$ & approximately & 1.0 \\
\hline \multicolumn{3}{|l|}{ Solids Plus Solution: } \\
\hline Total Solids $(\mathrm{g} / \mathrm{l})$ & & 126.9 \\
\hline Undissolved Solids $(g / 1)$ & & 53.8 \\
\hline \multicolumn{3}{|l|}{ Overall Molar Composition: } \\
\hline AI $(\underline{M})$ & & 0.334 \\
\hline $\operatorname{Zr}(\underline{M})$ & & 0.252 \\
\hline $\mathrm{Ca}(\underline{M})$ & & 0.930 \\
\hline$F(\underline{M})$ & & 1.614 \\
\hline Ca/F Mole Ratio & & 0.585 \\
\hline
\end{tabular}

steady state values of various experimental parameters are shown in Table $X V$. The average chemical compositions of the calcined solids and of the scrubbing solution are shown in Tables XVI and XVII, respectively. Analysis of the off-gas for fluoride showed 10 micrograms of fluoride per liter of gas at an off-gas rate of 44 scfm.

The results of this work indicate that zirconium wastes can be successfully calcined at $400^{\circ} \mathrm{C}$ with a $1.0 \mathrm{ft} / \mathrm{sec}$ fluidizing velocity with the resulting product having a satisfactory attrition resistance.

TABLE XIV

OPERATING CONDITIONS FOR PILOT PLANT CALCINATION OF ZIRCONIUM WASTE

Starting Bed Material

Starting Bed Weight

Calculated Incipient Fluidization Velocity

Bed Temperature

Nozzle Air Ratio

Fluidizing Velocity

Average Feed Rate

Run Duration
Alumina calcine

$139.71 \mathrm{bs}$

$0.39 \mathrm{ft} / \mathrm{sec}$

$400^{\circ} \mathrm{C}$

650 and 700

$1.0 \mathrm{ft} / \mathrm{sec}$

$16.11 / \mathrm{hr}$

2.12 hours 


\section{$\underline{\text { TABLE XV }}$}

STEADY STATE VALUES OF EXPERIMENTAL PARAMETERS

\begin{tabular}{lc}
\hline Fluidized Bed Density & $1.1 \mathrm{~g} / \mathrm{cc}$ \\
Bed Height & 31.2 inches \\
$90 \%$ Bed Replacement Time & $110 \mathrm{Hours}$ \\
Bed Weight & $204 \mathrm{lbs}$. \\
Calcined Solids Rates : & $4.3 \mathrm{lb} / \mathrm{hr}$ \\
$\quad$ Product & $0.33 \mathrm{lb} / \mathrm{hr}$ \\
Fines & $0.12 \mathrm{lb} / \mathrm{hr}$ \\
$\quad$ Solids to Scrub System & $3.15 \mathrm{~g} / \mathrm{cc}$ \\
Properties of the Fines & $0.38 \mathrm{~g} / \mathrm{cc}$ \\
Absolute Dersity & $0.62 \mathrm{~mm}$ (approximate) \\
Bulk Density & $1.4 \mathrm{~g} / \mathrm{cc}$ \\
Properties of the Product & $3.35 \mathrm{~g} / \mathrm{cc}$ \\
Mass Median Particle Diameter & $2.2 \mathrm{~g} / \mathrm{cc}$ \\
Bulk Density & 78 \\
Absolute Density & 0.35 \\
Particle Density & \\
Attrition Index & \\
Intra-Particle Porosity & \\
\hline
\end{tabular}

TABLE. XVI

CHEMICAL COMPOSITION OF CALCINED SOLIDS

\begin{tabular}{lccr}
\hline \multicolumn{1}{c}{ Component } & $\frac{\text { Product }}{2.5}$ & $\frac{\text { Fines }}{8.0}$ \\
\hline $\mathrm{NO}_{3}(\mathrm{wt} \%)$ & 17.1 & 19.2 \\
$\mathrm{Zr}(\mathrm{wt} \%)$ & 13.0 & 19.6 \\
$\mathrm{~F}(\mathrm{wt} \%)$ & 28.2 & 30.5 \\
$\mathrm{Ca}(\mathrm{wt} \%)$ & 7.1 & 6.0 \\
$\mathrm{Al}(\mathrm{wt} \%)$ & & 9.5 \\
Total Volatiles at $700^{\circ} \mathrm{C}(\mathrm{wt} \%)$ & & \\
\hline
\end{tabular}




\begin{tabular}{lc}
\hline $\mathrm{H}^{+}(\underline{\mathrm{Na}})$ & $\approx 4.2$ \\
$\mathrm{NO}_{3}^{-}(\underline{\mathrm{M}})$ & $\approx 4.6$ \\
$\mathrm{Zr}^{+4}(\mathrm{~g} / \mathrm{l})$ & $\approx 1.3$ \\
$\mathrm{Al}^{+3}(\mathrm{~g} / \mathrm{l})$ & $\approx 0.5$ \\
$\mathrm{~F}^{-}(\underline{\mathrm{M}})$ & $\approx 0.17$ \\
$\mathrm{Ca}^{+2}(\underline{\mathrm{M}})$ & $\approx 0.06$ \\
Undissolved Solids $(\mathrm{g} / \mathrm{l})$ & None by Visual Inspection \\
Total Solids (g/l) & $\approx 8.5$
\end{tabular}

2.2 Fluidized Bed Calcination Using In-Bed Combustion of Fuel (T. K. Thompson, S. J. Horn; Development Engineering Section)

An in-bed combustion process is being investigated as an alternate means of supplying heat directly to a fluidized bed calcination process without involving the use of a liquid metal $(\mathrm{NaK})$ heat transfer medium. The process consists of spraying kerosene or kerosene vapor directly into a preheated fluidized bed through a two-fluid atomizing nozzle, while simultaneously calcining nitric acid or a nitrate-containing waste in the bed. Combustion occurs spontaneously and can be controlled by regulating the concentration of oxygen in the fluidizing gas. Above-bed burning is indicated by a vapor space temperature greater than the bed temperature; whereas in-bed burning is indicated by a bed temperature equal to or greater than the vapor space temperature. The presence of the decomposition products from the calcination of nitrate-containing waste solution is essential for operation at temperatures less than $675^{\circ} \mathrm{C}$. Startup of the process has been achieved at temperatures as low as $400^{\circ} \mathrm{C}$ by preheating the bed. Theoretical calculations indicate that a significant increase in energy input to the 12-inch-diameter calciner is possible as compared with the original heating system.

2.21 Combustion Tests in a Four-Inch-Diameter Fluidized Bed. Preliminary tests to determine minimum combustion temperatures were conducted in a fourinch-diameter open-top vessel shown in Figure 19. This unit simulated the calciner vessel only, since no off-gas system existed. A two-fluid atomizing nozzle in the two-inch-diameter section was used to atomize the fuel with an adjustable mixture of air and pure oxygen. The fluidizing gas mixture could be adjusted to provide any desired proportion of air and oxygen. Preheating of the bed was accomplished by using external electrical resistance heaters.

Results obtained in the four-inch unit indicated that a minimum bed temperature of $650^{\circ} \mathrm{C}$ was required for spontaneous ignition and smooth in-bed burning of either kerosene or diesel fuel. Varying the proportions of air and oxygen, bed material or depth, and fuel material had no apparent effect on this 
minimum temperature. These tests were carried out using both alumina and zirconia calcine fluidized beds.

2.22 Calcination with In-Bed Combustion. A 12-inch-diameter calciner, equipped with an off-gas scrubbing system, was used in studies to determine if calcination of simulated wastes and combustion of kerosene could be accomplish simultaneously. A flow sheet of this unit is shown in Figure 20.

Preliminary tests in the 12 -inch unit substantiated the data obtained in the four-inch unit, indicating that unit size played a negligible overall role in the in-bed combustion process. When a therind loal, nnnststing of water feed at seven liters per hour, was imposed on the process, ahove-hed biring occurred at temperatures around $675^{\circ} \mathrm{C}$. These tests were conducted with the top flange removed from the calciner vessel.

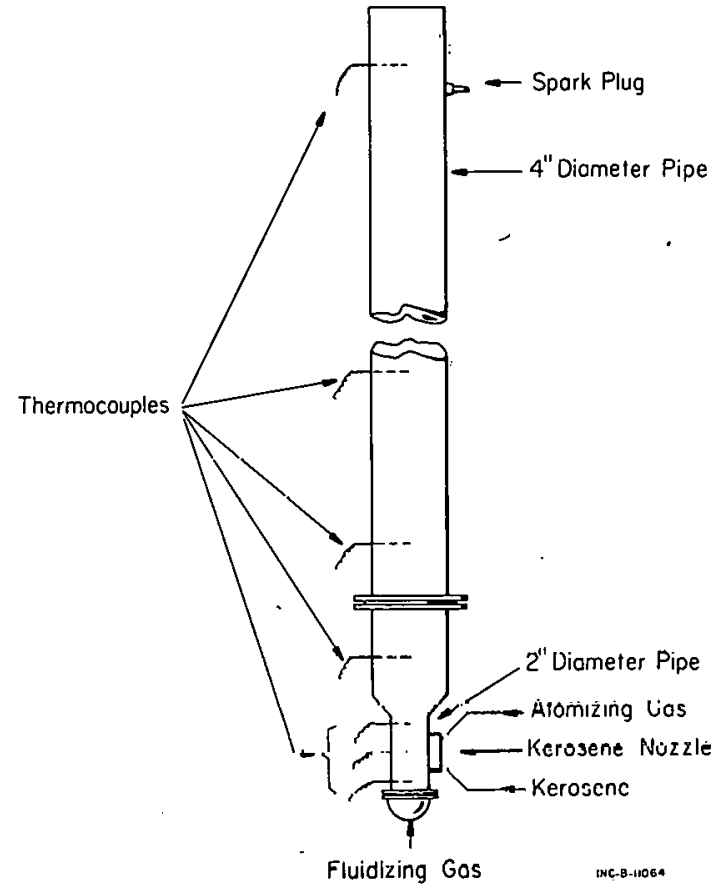

Fig. 19 Four-inch-dtameter calciner.

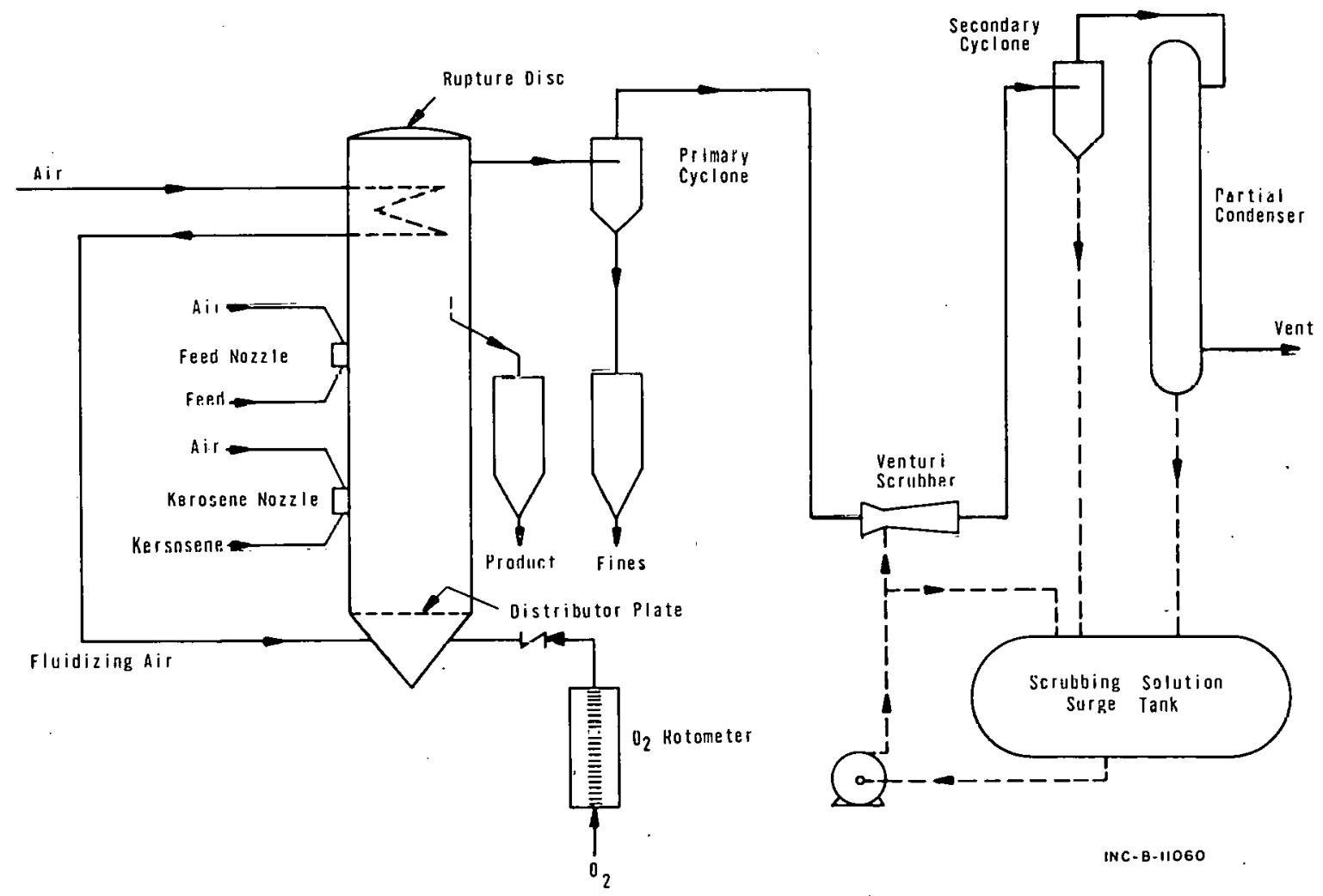

Fig. 20 Simplified flow sheet of in-bed combustion calciner system. 
When nitrate-containing wastes were substituted for the thermal load, the combustion conditions changed dramatically. Results indicate that the aluminum nitrate type wastes can be calcined at temperatures as low as $440^{\circ} \mathrm{C}$ while maintaining in-bed burning of the kerosene. Similarly, zirconium-type wastes can be calcined at $460^{\circ} \mathrm{C}$. Indications of process stability were apparent with both types of waste. In addition, this test was repeated using only nitric acid as feed. With $2 \mathrm{M} \mathrm{HNO}_{3}$, the minimum temperature at which spontaneous ignition and stable in-bed combustion could be maintained was $455^{\circ} \mathrm{C}$; and with $13 \mathrm{M}$ HNO3, the minimum temperature was $400^{\circ} \mathrm{C}$. The operating conditions for each case were identical, with the exception of the lower bed temperature achieved with the $13 \mathrm{M}$ nitric acid.

Tests were made to determine the minimum bed temperatures required for in-bed Ignition of kerosene while acidic aluminum nitrate waste was being sprayed into the fluidized bed composed of alumina particles. The procedure was to preheat the bed to a temperature of $50^{\circ} \mathrm{C}$ above the desired test temperature. The heaters were then shut off and the aluminum nitrate feed started. When the bed reached the desired temperature, kerosene injection was started. Results to date indicate that spontaneous ignition can be achieved in alumina beds at bed temperatures of $400^{\circ} \mathrm{C}$ and greater. These tests were duplicated using a dolomite startup bed material. Results to date indicate that ignition followed by in-bed burning occurs at bed temperatures of $460^{\circ} \mathrm{C}$ and higher.

Tests were conducted to determine the minimum amount of pure oxygen required in the 12 -inch diameter calciner. Experimental results indicated that 3 to $4 \mathrm{scfm}$ of oxygen were required in addition to the $1.0 \mathrm{scfm}$ of pure oxygen and $18.7 \mathrm{scfm}$ of total air that were expected. Analyses of the off-gas showed no evidence of incomplete combustion nor did samples of the scrub or solid product. The discrepancy between the theoretical and actual oxygen requirements indicates that excess oxygen over the stoichiometric quantities may be necessary to achieve stable in-bed combustion.

\subsection{Startup Beds For the WCF}

(S. J. Horn, T. K. Thompson; Development Engineering Section)

The need for a heat stable, abrasion resistant, acid soluble startup bed material compatible with the calcination process in the Waste Calcining Facility (WCF) has been apparent since the March 1966 startup of the WCF. Prior to 1966 , nonradioactive calcined alumina from startup test operations was available for use as a startup bed. After the supply of this material was exhausted, a substitute bed material was needed. During the 1966 startup, alumina mixed with sand was used as the starting bed. Part of this sand was elutriated from the bed and carried into the feed system, via blended scrub solution, where it contributed significantly to feed control problems because of its insolubility in nitric acid and consequent tendency to plug valves and orifices. A literature search for alternate starting bed materials resulted in three materials being selected for testing: Magnorite $\mathrm{X}(\mathrm{MgO})$, aragonite $\left(\mathrm{CaCO}_{3}\right)$, and dolomite $\left[\mathrm{CaMg}\left(\mathrm{CO}_{3}\right)_{2}\right]$. The selection was based primarily on thermal stability at calcination temperature, solubility in nitric acid, and availability of materials.

Preliminary tests, such as screen analysis, attrition resistance, and solubility in WCF scrub solution were undertaken to characterize the materials. Dolomite was subjected to calcination conditions at a temperature of $400^{\circ} \mathrm{C}$ in the two-inch-diameter calciner to determine if its high carbonate content would react with the acidic waste at calciner operating conditions and result 
in destruction of the bed particles. This test was successful in all respects: no decomposition of the dolomite was evident, and the alumina calcine coating adhered to the particles. Subsequent testing of all three materials was performed in the 12-inch-diameter calciner.

All three materials were received in an "as-crushed" condition. The materials were screened and the fraction smaller than 16 Tyler mesh screen and greater than 92 Tyler mesh was used as the starting bed. The resulting material had a mass median particle diameter of 0.4 to $0.5 \mathrm{~mm}$. All three candidate materials were tested under operating conditions in the 12-inchdiameter calciner for approximately 24 hours. Results indicated that all three materials are suitable for use as startup beds. In general, the materials had low attrition resistance and produced a greater amount of fines than alumina calcine, but had good solubility in nitric acid scrub solutions. Because of this high solubility, any fines elutriated were readily dissolved in the scrubbing solution and thus could be recycled to the feed system without difficulty. Due to its lower cost and local availability, dolomite was selected for a five-day test to study the long-term effects of its use as a startup bed material.

The five-day run using dolomite confirmed the results of the 24-hour test. A simulated acidic aluminum nitrate waste was fed at a rate of $221 / \mathrm{hr}$ to duplicate the vapor space velocities encountered in the Waste Calcining Facility. The total operating time was 112 hours, which allowed approximately one bed turnover to occur. The bed height remained at six inches above the nozzle during the entire run, and control of the mass median particle diameter was obtained by adjusting the nozzle air ratio. The fines elutriation rate was 100 percent of the theoretical solids production rate for the first 15 hours, but by the end of the run it had dropped to normal levels associated with alumina calcine ( $\approx$ six percent of the theoretical solids production rate). By the end of this test the bed was essentially 100 percent alumina calcine.

In addition to the five-day run, several tests were made simulating the NaK heating period in the WCF using dolomite as the starting bed material. High fines rates were again observed but the elutriated material was easily handled by the scrubbing system due to the high solubility of the dolomite in the nitric. acid scrubbing solution.

Dolomite has been selected as a startup bed material for the WCF. The mineral is crushed and screened to $-16+30$ Tyler mesh screen size with a mass median particle diameter of $0.45 \mathrm{~mm}$. The WCF was successfully started up using a dolomite starting bed on March 24, 1967.

\subsection{Valveless Feed Control for the WCF}

(P. E. LaMont; Development Engineering Section)

Suspended solids in the feed to the WCF calciner have caused occasional plugging of the flow control valves in the feed system. A propusal has been made to remove the valves and to control the feed flow rate with a fluid vortex amplifier used as a vortex restrictor. Studies are currently underway to test a commercial vortex amplifier in a mocked-up feed system.

2.41 Vortex Reslriclor Description. A vortex restrictor is essentially a right circular cylindrical chamber into which the main fluid stream enters radially through a large port in the wall of the cylinder, and the controlling streams enter tangentially through tiny ports also in the wall of the cylinder. 
Figure 21 is a cut-away view of a vortex restrictor. The combined fluids exit axially through a small port on the end of the cylinder. The tangential'jets generate a vortex which is confined inside the chamber. By increasing the control stream flow rate, the pressure drop across the vortex is increased due to the greater angular and radial accelerations of the fluid and greater friction loss; because of the greater pressure drop, the main stream flow rate decreases. When the pressure drop across the vortex is significant compared to the overall pressure drop in the system, the flow rate can be controlled.

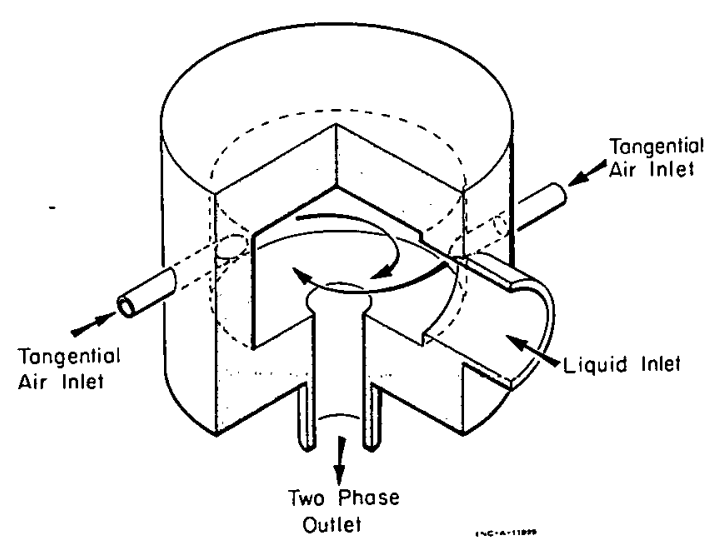

Fig. 21 Cut-away view of vortex restrictor. In conventional applications, the main and controlling streams are both the same fluid, usually air. In the calciner feed control system, the main stream is the liquid waste and the controlling stream is air. This eliminates dilution of the feed by the control fluid. Performance is highly dependent upon chamber dimensions. In test run to date, a oneinch-diameter commercial model was used. Although tests are not yet conclusive, the results indicate that the pressure drop across the two-phase vortex is stable with respect to time.

2.42 Simulated Feed System Tests. The vortex restrictor can be operated in two basic ways. Air from the two-phase outlet stream can be disengaged below the restrictor, or the two-phase outlet stream can be fed directly to the nozzle without the air being disengaged. Figure 22 is a schematic drawing of the test system showing both methods of operation. The overall head in the test system was the same as in the WCF feed system, and a full-scale calciner feed nozzle was used. Both water and aluminum nitrate solution were metered. For testing purposes, the range of control desired was from 90 to 20 gallons/ hour net flow of liquid.

The results of the preliminary tests using a disengaging pot to separate the air from the liquid indicate that the liquid flow rate can be adjusted from greater than 90 to less than 20 gallons/ hour. A greater head between the restrictor and the constant. head tank requires a greater quantity of air for a given liquid flow rate. The restrictor was tested on levels from five to eight feet below the constant head tank; air rates up to 11 scfm were needed to reduce the flow to less than 20 gallons/hour. Once the air rate was set, the liquid rate remained essentially constant, confirming the formation of a stable two-phase vortex.

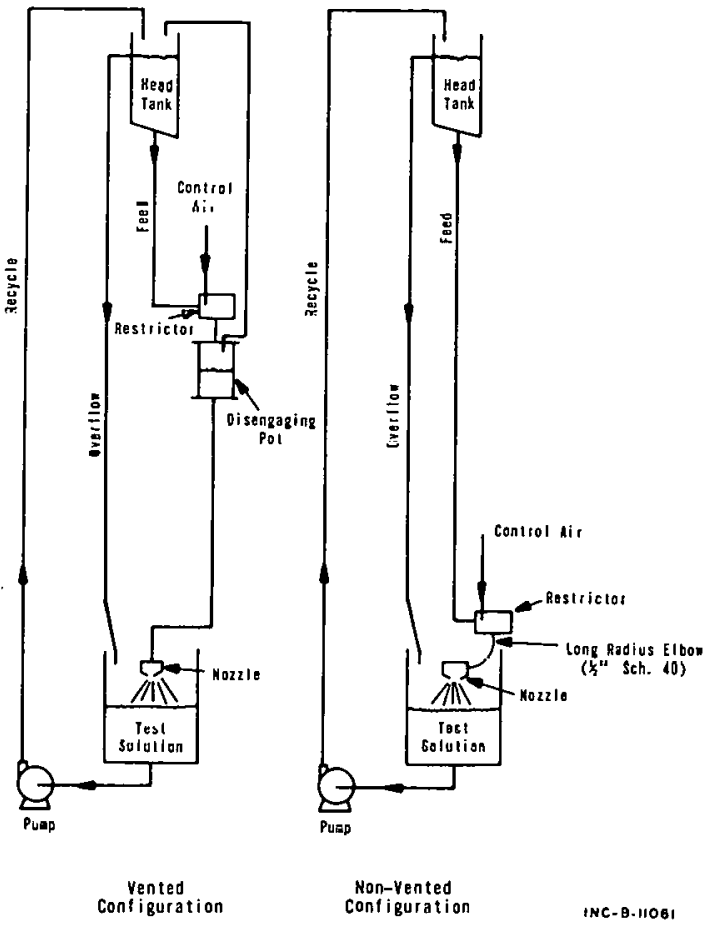

Fig. 22 Schematic diagram of apparatus for testing vortex restrictor operation. 
The predictable nature of the response is particularly desirable in remote installations. In this system, the restrictor position and disengaging pot configuration must be chosen correctly so that the liquid will drain from the disengaging pot to the nozzle at all flow rates. Foam accumulation in the disengager pot has been a problem.

Tests using the nonvented system indicate that performace is dependent upon orientation and location of the vortex restrictor. When the restrictor is separated from the nozzle by a combination of horizontal and vertical runs of pipe! large pressure and flow fluctuations occur which are characteristic of two-phase flow. When the restrictor is separated from the nozzle by a minimum of pipe, cycling is reduced to a tolerable level and satisfactory flow control is obtained. A performance curve for the nonvented system is shown in Figure 23. The steep slope at low air flow rates and the shallow slope at high air flow rates are typical of both vented and nonvented performance curves.

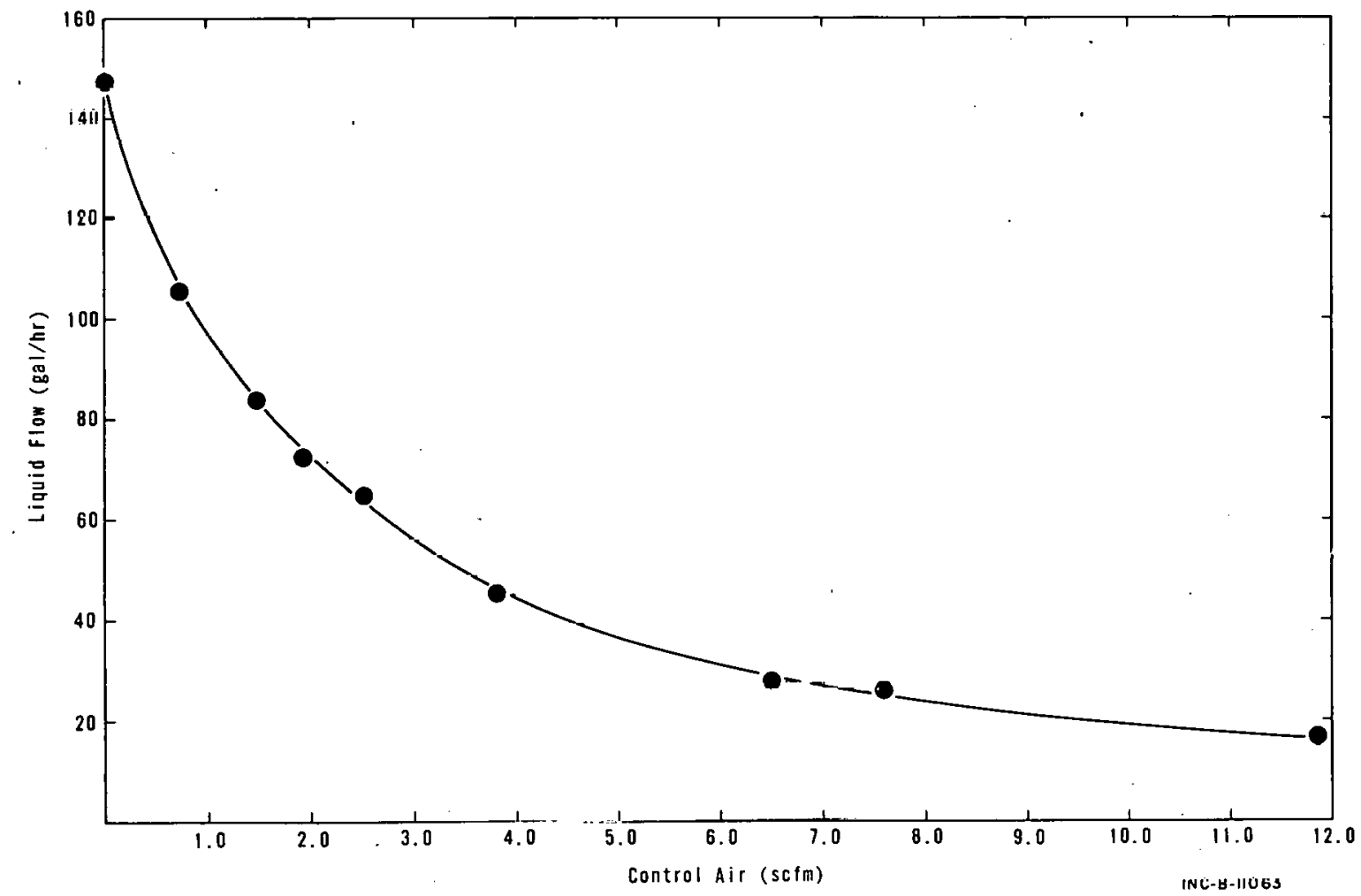

Fig. 23 Vortex restrictor performance curve.

2.43 Future Studies. The rates of corrosion and erosion of the'vortex chamber are unknown at present. It is planned to construct a restrictor of stainless steel for installation in a test loop which will be run unattended for long periods. Simulated aluminum and zirconium wastes will be used in the tests. A flowmeter and controller will be installed in the loop to test restrictor performance as a control element.

\subsection{Corrosion-Erosion Testing of Materials Used in WCF Construction} (T. K. Thompson, S. J. Horn; Development Engineering Section)

In anticipation of the Waste Calcining Facility operating with zirconium waste feedstock late in 1967, a recirculating test loop has been designed and constructed to study the combined corrosion and erosion properties of a synthetic, 
zirconia bearing, acidic scrub solution. The composition of this solution is based on results obtained in pilot plant calcination of simulated zirconium waste in the 12 -inch-diameter calciner. The solution is made by mixing fines from the pilot plant runs with a nitric acid solution.

Materials of construction for the test apparatus, with the exception of the silicon carbide spray nozzle, are the various stainless steel alloys that exist in the WCF scrub system, namely Types $304,304 \mathrm{~L}$, and 347 . A flow sheet of the test unit is shown in Figure 24. The pump is a Hazleton double volute, centrifugal slurry pump.

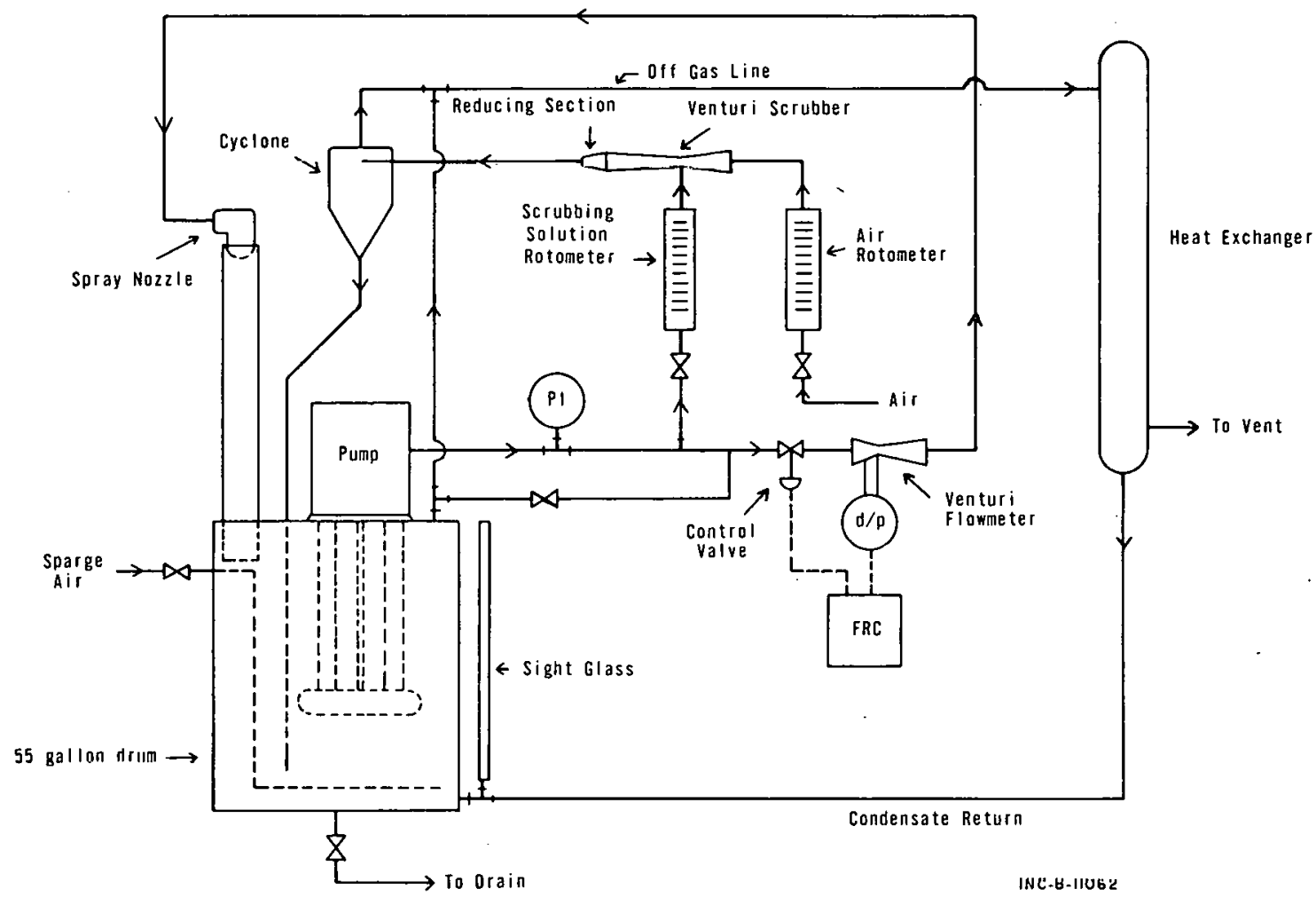

Fig. 24 Schematic diagram of corrosion-erosion test loop.

The first operating period comprised a total of 463 hours of operating time at $29^{\circ} \mathrm{C}$ and 12.5 psia. The average composition of the synthetic scrubbing solution used during this period is given below:

$\begin{array}{ll}\mathrm{H}^{+} & 2.5 \underline{\mathrm{M}} \\ \mathrm{NO}_{3}^{-} & 2.5 \underline{\mathrm{M}} \\ \mathrm{Zr}^{++} & 0.5 \mathrm{~g} / 1 \\ \mathrm{Al}^{+3} & 0.4 \mathrm{~g} / 1 \\ \mathrm{~F}^{-} & 0.13 \mathrm{~g} / 1 \\ \text { Undissolved Solids } & 0.07 \mathrm{~g} / 1\end{array}$


A comparision of pertinent operating parameters of the WCF and the corrosion-erosion loop test is given in Table XVIII.

TABLE XVIII

COMPARISON OF WCF AND TEST OPERATING CONDITIONS

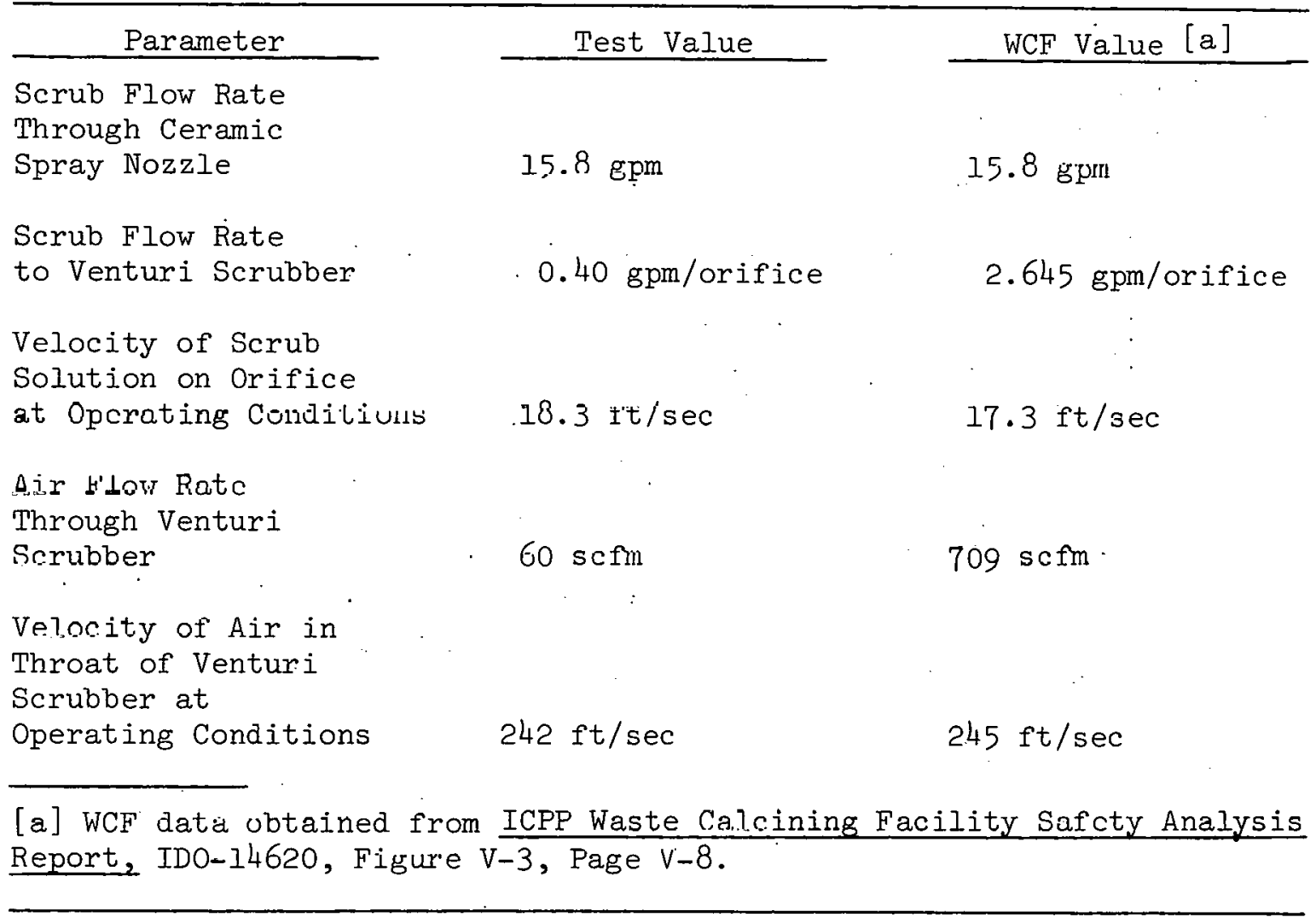

At the end of the operating period, the test loop was dismantled and various components were measured for corrosion. Each piece was cleaned in boiling 35 percent $\mathrm{HNO}_{3}$, water rinsed, acetone washed, air dried, and weighed. Cor rosion rates, based on weight loss, for various components are given in Table XIX. No metal loss could be measured at the throat or orifices of the venturi scrubber although weight loss indicated some general corrosion of the equipment (Table XIX). 'I'he control valve was a dual-plug design constructed of Type 316 stainless steel. Measurement of the plugs and seats revealed an approximate $0.001-$ inch decrease in the outside diameter of the top plug whereas the lower plug diameter remained unchanged. The top seat increased in inside diametcr by 0.0006 inch and the bottom seat increased by 0.0001 inch. 


\begin{tabular}{lc}
\hline \multicolumn{1}{c}{ Equipment Item } & $\begin{array}{c}\text { Corrosion-Erosion Rate } \\
\text { (mils/month) }\end{array}$ \\
\hline Silicon Carbide Spray Nozzle & 0.03 \\
Venturi Flowmeter (304) & 0.08 \\
Venturi Scrubber (304L) & 0.31 \\
Reducing Section (347-304-347) & 0.00 \\
3/4-inch ELL in Spray Nozzle Leg (347) & 0.05 \\
Pump Impeller & 0.01 \\
\hline
\end{tabular}

2.6 Model for Transient Particle Size Distribution in Fluidized Bed Calciner (B. R. Dickey, E. S. Grimmett; Development Engineering Section)

Mathematical modeling of the transient particle size distribution within the fluidized bed calciner[1] has continued during the year. The model's greatest potential is in predicting the response of the particle size distribution within the fluidized bed to changes in the feed rate, feed density, fluidizing gas velocity, and gas density. Correlation of the nozzle air-to-liquid feed ratio (NAR) in terms of a pseudo seed addition rate is required before the validity of the model can be established by comparison with actual plant data.

The form of the equations previously stated [1,19] and the computer program based on these equations are cumbersome and require excessive computer time. A more efficient computational algorithm for determining the transient response can be derived as follows. The cumulative weight fraction in the fluidized bed as a function of particle size and time is given by the following partial differential equation [19]:

$$
\frac{\partial^{2} W_{f}}{\partial L^{2}}+\left[\frac{A_{c} k_{e}(L)}{W_{B} g(L)}+\frac{P}{W_{B} g(L)}-\frac{3}{L}\right] \frac{\partial W_{f}}{\partial L}=\frac{S}{g(L) W_{B}} \frac{\partial W_{S}}{\partial L}-\frac{1}{g(L)} \frac{\partial^{2} W_{f}}{\partial L \partial t} .
$$

where

$\mathrm{W}_{\mathrm{f}}=$ cummulative weight fraction, dimensionless

$\mathrm{A}_{\mathrm{C}}=$ cross-sectional area of the bed, $\mathrm{ft}^{2}$

$\mathrm{W}_{\mathrm{B}}=$ weight of the bed, grams

$$
g(L)=\left(\frac{2 \Gamma}{\rho_{s}}\right) \sum_{i=1}^{\infty} S_{i}(a+b L) \ldots, f t / h r
$$




$$
\begin{array}{ll}
\mathrm{k}_{\mathrm{e}}(\mathrm{L}) & =\text { rate constant for elutriation, } \mathrm{g} / \mathrm{ft}^{2}-\mathrm{hr} \\
\mathrm{P} & =\text { product rate, } \mathrm{g} / \mathrm{hr} \\
\mathrm{S} & =\text { seed addition rate, } \mathrm{g} / \mathrm{hr} \\
\mathrm{L} & =\text { particle diameter }, \mathrm{cm} \\
\mathrm{t} & =\text { time, } \mathrm{hr} .
\end{array}
$$

Equation (1) can be simplified by defining new quantities and making a change of the dependent variable; thus let

$$
\begin{aligned}
\phi_{f} & \triangleq \frac{\partial W_{f}}{\partial L} \\
K(L) & =\frac{A_{C} k_{C}(L)}{W_{B} g(L)}+\frac{P}{W_{B} g(L)}-\frac{3}{L} \\
\psi_{S} & =\frac{\partial W_{S}}{\partial L}
\end{aligned}
$$

Equation (1) then becomes

$$
\frac{\partial \phi_{f}}{\partial L}+K(L) \phi_{f}=\frac{S \psi_{S}}{g(L) W_{B}}-\frac{I}{g(L)} \frac{\partial \phi_{f}}{\partial t} \ldots
$$

Since the growth rate $g(L)$ is dependent on the total surface area of the particles in the bed, a small $\Delta \mathrm{L}$ is required in the range of small particles sizes. However, a small $\Delta L$ increases the machine computation time. A variable size $\Delta L$ satisfies both the criteria for calculation of an accurate surface area and a reasonable computation time.

Finite differencing Equation (2) for the case where the increment $\Delta L$ increases linearly with $L$ yields

$$
\frac{2 \phi_{m+1}-2\left(1-k^{2}\right) \phi_{m}-2 k^{2} \phi_{m-1}}{2 k^{m-1}(k+1) \Delta L_{1}}+K(L) \phi_{m}=\frac{S \psi_{s, m}}{g(L) W_{B}}-\frac{1}{g(L)} \frac{\left[\phi_{m, t}+\Delta t-\phi_{m, t}\right]}{\Delta t} \text {. }
$$

Equation (3) can be simplified and rearranged to give the following set of equations: .

$$
\begin{aligned}
& \mathrm{K}_{2} \emptyset_{2, t+\Delta t}+2 \emptyset_{3, t+\Delta t}=\frac{\beta_{2} S \psi_{2}}{g(L) W_{B}}+\frac{B_{2} \emptyset_{2}, t}{g(L) \Delta t} \\
& -2 k^{2} \phi_{m-1, t+\Delta t}+K_{m} \phi_{m, t+\Delta t}+2 \phi_{m+1, t+\Delta t}=\frac{\beta_{i} S \psi_{m}}{g(L) W_{B}}+\frac{\beta_{m} \phi_{m} t}{g(L) \Delta t} \\
& (m=3,4, \ldots M-?) \\
& -2 k^{2} \phi_{M-2}+K_{M-1} \emptyset_{M-1}=\frac{{ }_{m-1} S \psi_{m-1}}{g(L) W_{B}}+\frac{{ }_{m-1} \phi_{m-1, t}}{g(L) \Delta t}
\end{aligned}
$$


where

$$
\begin{aligned}
\beta_{\mathrm{m}} & =2 \mathrm{k}^{\mathrm{m}-1}(\mathrm{k}+\mathrm{l}) \Delta \mathrm{L}_{\mathrm{I}} \\
\mathrm{K}_{\mathrm{m}} & =\beta_{\mathrm{m}}\left[\mathrm{K}(\mathrm{L})+\frac{\mathrm{l}}{\mathrm{g}(\mathrm{L}) \Delta t}\right]-2\left(1-\mathrm{k}^{2}\right) \\
\mathrm{M} & =\text { designation of the largest particle size } \\
\mathrm{m}-1, \mathrm{~m}-2 & = \\
& \text { one and two particle sizes smaller, respectively, than }
\end{aligned}
$$

Equation (4) is in the form of a tridiagonal matrix and can be readily solved for the unknowns, $\emptyset_{\mathrm{m}}, t+\Delta t$, by a calculational procedure based on Gaussian elimination. Any change in the factors affecting the particle size distribution is reflected in a change in the scaler quantities $K_{m}, \beta m, S, W_{B}$, and $g(L)$. A revised digital computer program, based on the system of Equations (4), was written in FORTRAN for the IBM-7040.

The transient particle size distribution calculated by the new procedure yielded the same results as the earlier method and the computer time was decreased by a factor of eight. Use of the model in predicting the particle size response to disturbances or arbitrary changes within the plant calciner will depend on the ability to correlate the effect of the NAR on the particle size distribution.

\section{PROPERTIES OF SOLID CALCINED WASTE}

\subsection{Volatility of Minor Constituents from Calcine \\ (M. E. Jacobson; Chemistry Section)}

After converting the highly radioactive aqueous wastes at the Idaho Chemical Processing Plant to granular solids in the Waste Calcining Facility, the solids are stored underground in large stainless steel bins. The center-line temperature of the calcine may be as high as $700^{\circ} \mathrm{C}$ during storage due to radioactive decay of the contained fission products. The distribution of the constituents that are volatile in the heated calcine changes during the period of high heat generation, with migration occurring from the hot zone to a cooler zone.

To determine what constituents migrate from the higher temperature regions during long-term heating, volatility experiments were run using radioactive calcine-from the WCF. In these experiments, two-gram samples of WCF calcine were placed in small, open alumina tubes and inserted into combustion tube furnaces. Temperatures were controlled at 525,700 , and $800^{\circ} \mathrm{C}$ for one year. Samples of the solid calcine were removed after six months and after one year, and fission product content, mercury content, and crystallinity of the alumina were determined. The results are given in Tables XX and XXI.

As expected, no volatilization of $\mathrm{Sr}-90$ and $\mathrm{Ce}-144$ occurred. Cesium began to volatilize somewhere between 700 and $800^{\circ} \mathrm{C}$, which agrees with the results oibtained previously[20] in short-term experiments. Ruthenium apparently 
TABLE XX

VOLATILITY OF MINOR CONSTITUENTS FROM WCF CALCINE DURING LONG-TERM HEATING

(Percent Volatilized)

\begin{tabular}{|c|c|c|c|c|c|c|}
\hline \multirow{2}{*}{$\frac{\text { Temperature }}{\left({ }^{\circ} \mathrm{C}\right)}$} & \multicolumn{2}{|c|}{ Cesium-137 } & \multicolumn{2}{|c|}{ Ruthenium-106 } & \multicolumn{2}{|c|}{ Mercury } \\
\hline & 6 month & 12 month & 6 month & 12 month & 6 month & 12 month \\
\hline 525 & 0 & 0 & --- & 54 & 25 & 93 \\
\hline 700 & 0 & 0 & 64 & 82 & 93 & $>97$ \\
\hline 800 & 77 & 86 & 99 & 99 . & $>96$ & $>96$ \\
\hline
\end{tabular}

TABILE XXI

CRYSTALLINITY OF WCF ALUMINA CALCINE DURING LONG-TERM HEATING

\begin{tabular}{lll}
\hline $\begin{array}{c}\text { Temperature } \\
\left({ }^{\circ} \mathrm{C}\right)\end{array}$ & $\frac{6 \text { months }}{525}$ & $\frac{12 \text { months }}{50-70 \% \text { gamma }}$ \\
700 & $<10 \%$ gamma & $50-70 \%$ gamma \\
800 & $25-40 \%$ gamma & $35-40 \%$ alpha \\
\hline
\end{tabular}

volatilized appreciably at $525^{\circ} \mathrm{C}$ during long-term heating. Mercury volatilized appreciably at all three temperatures although the effect of time was apparent onily at $525^{\circ} \mathrm{C}$.

The X-ray diffraction data indicated that amorphous alumina calcine stored at $700^{\circ} \mathrm{C}$ or lower temperatures formed gamma- $\mathrm{Al}_{2} \mathrm{O}_{3}$ consistently with no tendency to form any alpha- $\mathrm{Al}_{2} \mathrm{O}_{3}$. At $800^{\circ} \mathrm{C}$, however, crystalline alpha $-\mathrm{Al}_{2} \mathrm{O}_{3}$ was formed. The effect of time on the formation of both crystalline species is apparent to some extent in the data shown in Table XXI. Phase data cited in the literature [21] suggest that if the heating period is sufficiently long at or below $700^{\circ} \mathrm{C}$ to form gamma- $\mathrm{Al}_{2} \mathrm{O}_{3}$, this crystalline form will remain stable up to nearly $900^{\circ} \mathrm{C}$. If the heating period at or below $700^{\circ} \mathrm{C}$ is short and a temperature of $800^{\circ} \mathrm{C}$ or higher is obtained relatively soon, the alpha- $\mathrm{Al}_{2} \mathrm{O}_{3}$ will undoubtedly prédominate.

Based on the results of these one-year experiments, the following conclusions relative to long-term storage of alumina calcine in bins have been made:

(1) Essentially no cesium volatilizes at $700^{\circ} \mathrm{C}$ or lower temperatures, but significant amounts volatilize at $800^{\circ} \mathrm{C}$ or higher. 
(2) Appreciable quantities of ruthenium volatilize at temperatures as low as $525^{\circ} \mathrm{C}$.

(3) The orfginally amorphous alumina will convert to either gamma or alpha crystalline alumina depending on the temperature. Gamma alumina will be the only crystalline form at $700^{\circ} \mathrm{C}$ or lower, while alpha alumina will be the predominant crystalline form at $800^{\circ} \mathrm{C}$ or higher.

(4) Neither strontium nor cesium is volatilized during storage at $800^{\circ} \mathrm{C}$ or lower temperatures.

\subsection{Corrosive Effects of Zirconia Calcine in Storage}

(D. W. Rhodes, C. A. Zimmerman; Chemistry Section)

The calcining of zirconium fuel processing waste, containing fluoride, is planned in the near future. Presently available storage facilities are constructed of Type 304 stainless steel. Long-term corrosion tests have been initiated to evaluate the corrosion of the present material, as well as alternate materials of construction for future zirconium calcine storage vessels, in contact with this calcined waste product. The construction materials under test are Types 304, 304L, 316ELC, 347, and 405 stainless steels, carbon steel, and Type 6061 aluminum alloy. Tests are being conducted at $200^{\circ} \mathrm{C}$ (the expected maximum container wall temperature during storage) in a stainless steel vessel filled with zirconia calcine and supported in a tube furnace. The test specimens are separated and electrically insulated from each other by glass spacers. These materials will be examined initially for corrosion attack after an exposure of one year.

\section{HEAT TRANSFER STUDIES AFFECTING THE CALCINATION PROCESS AND STORAGE OF THE CALCINED PRODUCT}

4.1 Heat Transfer from Horizontal Tube Bundles to Fluidized Beds of Solids (J. C. Petrie; Process Engineering Section)

Criteria for the design of internal heat exchangers for fluidized beds are not presently available in the literature. Over the past several years, however, numerous applications of internal heat transfer in fluidized beds have been made at the Idaho Chemical Processing Plant in connection with the development and application of the waste calcination program. The purpose of this section, then, is to present correlations of these data and to indicate their applicability to design of heat exchangers for use in beds of fluidized solids.

Data for heat transfer from horizontal tube bundles to fluidized beds in the ICPP plant [18] and pilot plant calciners [22, 23] have been correlated with dimensionless moduli. A comparison of this correlation with one for heat transfer to a single horizontal tube from a fluidized bed [24] shows good agreement, indicating that the individual tubes are not significantly affected by others within the bundle. 
4.11 Data Correlation For Nonfinned Heat Exchanger Tubes. A Summary of the data used is given in Table XXII. The correlation best fitting the ICPP data for heat transfer from the various nonfinned heat exchangers to fluidized beds is shown in Figure 25 and can be represented by

$$
\mathrm{N}_{\mathrm{Nu}_{t}}=14\left(\frac{\mathrm{G}}{\mathrm{G}_{\mathrm{m}}}\right)^{1 / 3}\left(\mathrm{~N}_{\mathrm{Pr}}\right)^{1 / 3}\left(\frac{\mathrm{Dt}}{\mathrm{Dp}}\right)^{2 / 3}
$$

TABLE XXII

SUMMARY OF FLUIDIZED BED HEAT TRANSFER DATA

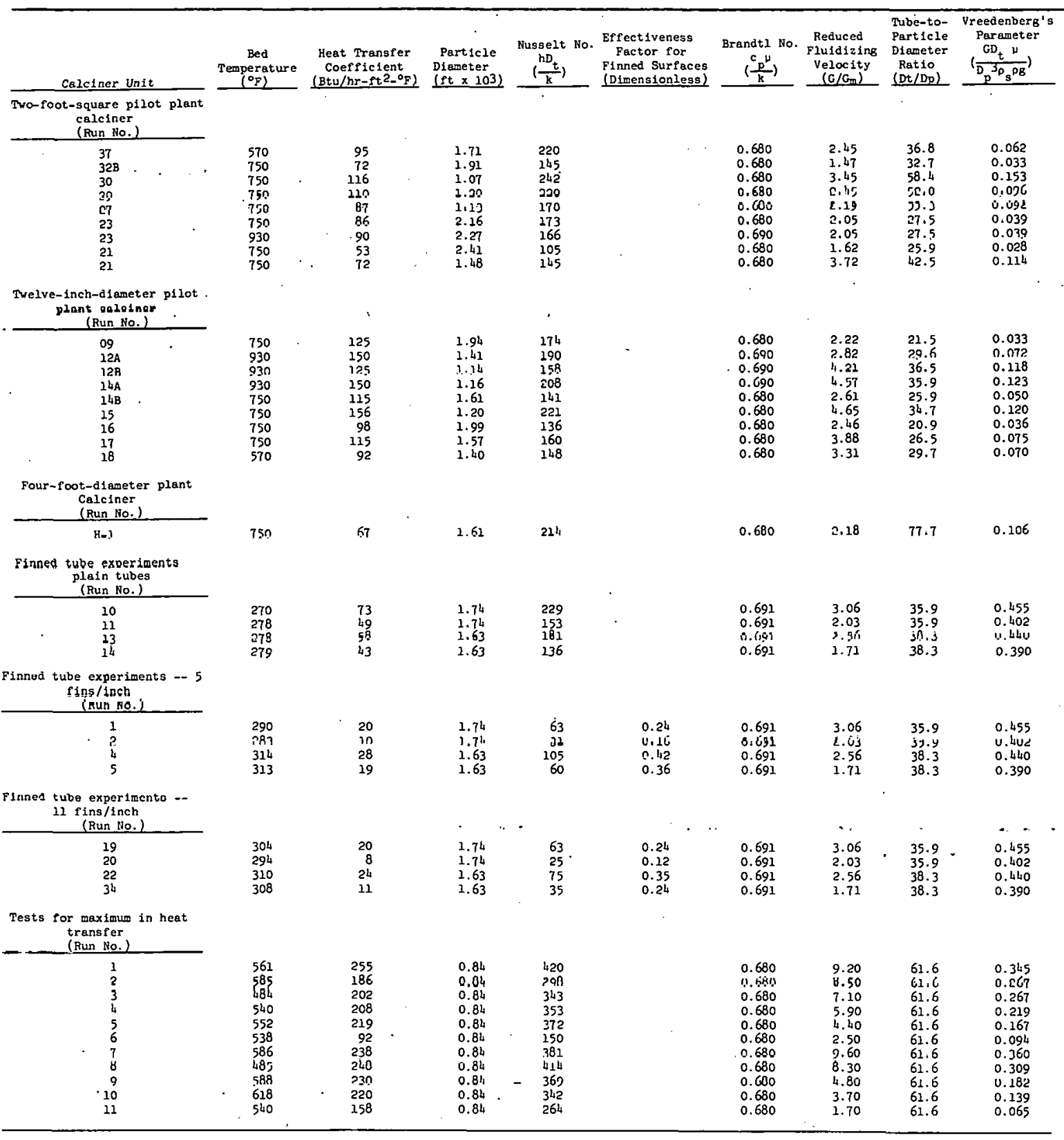




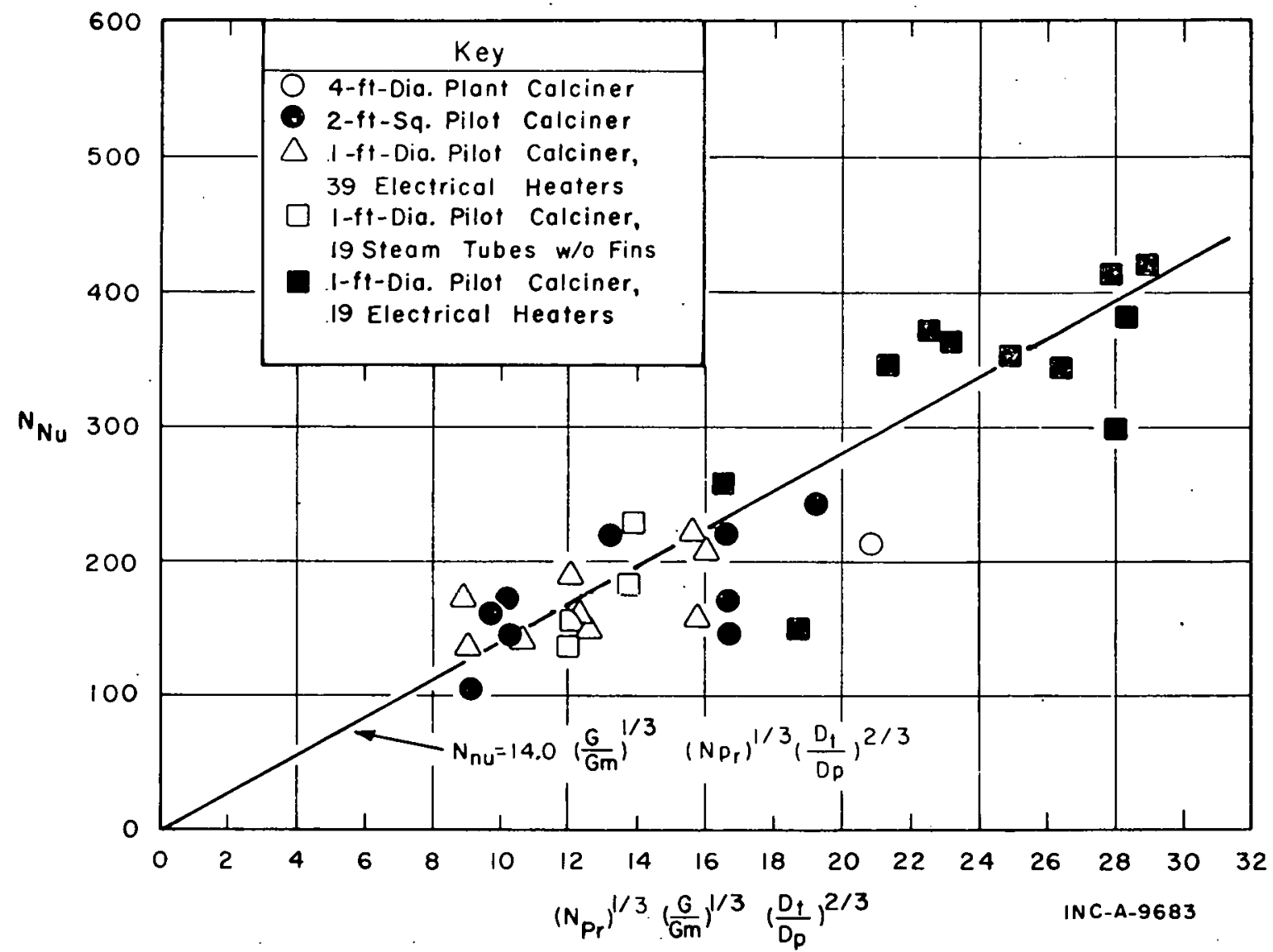

Fig. 25 Correlation of heat transfer data from in-bed heat exchangers.

where

$\mathrm{N}_{\mathrm{Nu}}=$ Nusselt number based on the tube diameter, dimensionless actual fluidizing air mass velocity

$\mathrm{G} / \mathrm{G}_{\mathrm{m}}=$ calculated minimum fluidizing air mass velocity reduced fluidizing air mass velocity ratio, dimensionless

$\mathrm{N}_{\mathrm{Pr}} \quad=$ Prandtl number of the fluidizing air, dimensionless

$\mathrm{Dt} / \mathrm{Dp}=$ ratio of tube diameter to particle diameter, dimensionless.

The exponents in Equation (1) were rounded to the given values from a linear regression analysis of a least squares fit of the data using an IBM-7040 computer. In this analysis, the Nusselt number divided by the Prandtl number to the $1 / 3$ power was treated as a function of the particle Reynold's number, the reducen fluidizing air mass flow ratio, and the tube-to-particle-diameter ratio. The particle Reynold's number was dropped from the final form of the data correlation because of its insignificant contribution. The exponent on the particle Reynold's number was only 0.06 in the linear regression analysis.

The maximum deviation of the data from Eqaution (1) is 43 percent. The Prandtl number of the fluidizing gas raised to a conventional exponent was included in the correlation even though the validity of this exponent could not be proved due to the small variation in Prandtl numbers during these tests. Fluid 
properties were arbitrarily determined at a "film" temperature, defined as the arithmetic average between the bed temperature and the surface temperature of the horizontal tubes.

The reduced fluidizing mass velocity is defined as the ratio of actual fluidizing air mass velocity divided by the calculated minimum fluidizing air mass velocity. The minimum fluidizing air mass velocity was calculated by the following formula presented by Leva [25]:

$$
G_{\text {min }}=1.40 \times 10^{5} \frac{\mathrm{Dp}^{1.85} \rho\left(\rho_{\mathrm{s}}-\rho\right)^{0.914}}{\mu^{0.88}}
$$

where

$$
\begin{aligned}
\mathrm{G}_{\min } & =\text { minimum fluidizing mass velocity, } 1 \mathrm{bs} / \mathrm{hr}-\mathrm{ft}^{2} \\
\mathrm{D}_{\mathrm{p}} & =\text { average particle diameter, } \mathrm{ft} \\
\rho & =\text { density of fluidizing air, } 1 \mathrm{bs} / \mathrm{ft}^{3} \\
\rho_{\mathrm{s}} & =\text { particle density of solid, } \mathrm{lbs} / \mathrm{ft}^{3} \\
\mu & =\text { viscosity of fluidizing air, } \mathrm{lhs} / \mathrm{ft}-\mathrm{hr} .
\end{aligned}
$$

This formula agrees best with experimental values for minimum fluidizing air mass velocities determined in the 12 -inch-diameter pilot plant calciner. Several formulas are available for predicting minimum fluidization mass velocities; all are similar to Leva's but use different constants and exponents [26]. Table XXIII compares experimental minimum fluidizing mass velocities for two beds of different particle sizes with the various formulas available for caloulating minimum fluidization mass velocities. The experimental data were determined by plotting pressure drop versus fluidizing air flow rate and selecting the velocity where the pressure drop becomes nearly constant as the minimum fluidizing air mass velocity [1]. As shown by the data in Table XXIII, experimental minimum fluidization mass velocities for beds typical of those at ICPP agree best with values calculated by Leva's formula. Therefore, all of the minimum fluidization mass velocities used in this study were calculated from Equation (2).

\section{TABLE XXIII}

MINIMUM FLUIDTZATION MASS FLOW RATE:

\begin{tabular}{lcc}
\hline & \multicolumn{1}{c}{$C_{\min }\left(1 \mathrm{ls} / \mathrm{hr}-\mathrm{ft}^{2}\right)$} \\
Theoretical Correlation $[26]$ & $\frac{\text { Bed No. 1 }}{137}$ & $\frac{\text { Bed No. 2 }}{121}$ \\
Frantz's Correlation $[26]$ & 29 & 28 \\
Leva's Correlation $[25]$ & 87 & 78 \\
ICPP Data & 71 & 68 \\
\hline
\end{tabular}


In the correlation represented by Equation (1), the reduced fluidizing mass velocity replaces the conventional Reynold's number for definition of the flow characteristics. By data analysis, it was found that the Nusselt number depended much less on the particle Reynold's number than on the reduced fluidizing air mass velocity. The reduced fluidizing mass velocity $\left(G / G_{m}\right)$ is felt to be more useful than a Reynold's number in fluidized bed work because the lower limit of $G / G_{m}$ is unity, and the magnitude of $G / G_{m}$ depicts a degree of fluidization better than any other single parameter.

A maximum in heat transfer rates as a function of fluidizing mass velocity or $G / G_{m}$, is expected[27]. However, no maximum was found in the Nusselt number as a function of $G / G_{m}$ although the maximum $G / G_{m}$ was slightly greater than 9. The predicted maximum must occur at some still higher value of $G / G_{m}$.

Data from both triangular and square pitch tube bundles were included in the correlation given in Equation (1); no significant difference is evident, further indicating that heat transfer from each tube is independent of that from its neighbors.

4.12 Conclusions: Heat transfer rates from multiple horizontal tubes to fluidized beds can be predicted by a dimensionless correlation of easily defined terms. The correlation shows that the heat transfer coefficient is inversely related to the particle diameter and the tube diameter and is directly related to the reduced fluidizing mass velocity. The reduced fluidizing mass velocity replaces the conventional Reynold's number normally appearing in heat transfer correlations.

Comparison of this correlation with a previous correlation for heat transfer from a fluidized bed to a single horizontal tube is reasonably good. This indicates that for tube-to-tube separations exceeding 43 particle diameters, there is no significant influence of other tubes within the heat exchanger. Data from heat exchangers having both triangular and square pitch tube arrangements were correlated by the same equation, further indicating independent heat transfer from the tubes.

Results of this study showed a continued increase in heat transfer coefficient with the one-third power of the gas velocity up to the test limit of a reduced fluidizing air mass velocity of 9; the expected maximum apparently occurs at some still higher mass velocity.

\subsection{Transfer of Heat from Finned Tubes to a Fluidized Bed \\ (E. S. Grimmett, W. A. Freeby; Development Engineering Section)}

The capacity of the fluidized bed waste calcination process - as well as that of many other fluidized bed processes - is limited by the rate at which heat can be transferred to the bed. With in-bed heating bundles, the controlling resistance to heat transfer is nearly always that on the bed side of the tubes. Increasing the heat transfer area on the bed side of the tubes by use of fins is, therefore, a. Ingical means of increasing heat transfer rates. However, considerable development work is indicated in this area to evolve combinations of fin design and fluidized bed operating parameters which lead to optimum performance. Initial testing has been performed and the results are promising; additional testing is continuing. 
Fundamentally, the goal is to determine combinations of conditions in which there is adequate fluidizing action in the spaces between the fins so that the actual surface heat transfer coefficient will be reasonably high, and at the same time have enough fins of reasonable length so that the actual area is large. Radial fins on horizontal tubes appeared to offer the best chance for success, and testing to date has been limited to this type. Principal equipment parameters are, then, number of fins per unit length of tube, fin height, tube diameter, and tube spacing. In limited testing to date, fin spacings ranging from 5 to 11 fins per inch have been used with fin heights of $0.4 \mathrm{inch}$, tube diameters have ranged from $5 / 8$ to $3 / 4$ inch, and tube center-line spacings have been about $2-1 / 4$ inches $[1,28]$.

The most significant bed operating parameters are believed to be particle size and reduced mass velocity; limited testing has been done with mass median particle diameters around $0.5 \mathrm{~mm}$ and with reduced mass velocities ranging from 1.5 to 15 .

Conclusions from the recent limited testing may be summarized as follows:

(1) Radial fins are effective in giving high rates of heat tranofer to fluidized beds without plugging or other operating problems.

(2) Limited testing of finned tube bundles has given overall heat transfer coefficients, based on the hare tube areas, of over $800 \mathrm{Btu} / \mathrm{hr}-\mathrm{ft}^{2}-{ }^{\circ} \mathrm{F}$; this is over five times that obtainable from bare tubes under comparable conditions. Heat transfer coefficients based on actual fin area, have been up to 50 percent of those for bare tubes, indicating good penetration of the fluidized bed particles into the spaces between the fins.

(3) Heat transfer rates from finned tubes are better for smaller particles and for higher flutdizing velocities over the limited ranges tested.

(4) Heat transfer rates were found to increase with increases in fluidizing velocity up to a reduced tluidizing velocity $\left(G / G_{m}\right)$ of 10; further increases in $G / G m$ resulted in decreased heat transfer rates.

(5) Additional testing, now underway, is necessary before the optimum combinations of finned tube design parameters and fluldized bed operating conditions can be defined.

4.3 Heat Dissipation from Buried Radioactive Sources

(B. R. Dickey, D. E. Black; Development Engineering Section)

The study of heat transfer from buried radioactive heat sources in the soli $[1,29]$ has been extended to include the case of transient temperatures within a container of buried waste. The boundary value problem for the transient temperatures within a large-diameter source and the surrounding medium is described by the following equations:

$$
\frac{\partial^{2} \mathrm{~T}_{1}}{\partial r^{2}}+\frac{1}{r} \frac{\partial \mathrm{T}_{1}}{\partial r}+\frac{\partial^{2} \mathrm{I}_{1}}{\partial z^{2}}+\frac{q^{\prime \prime}\left(r_{2}, t\right)}{\mathrm{k}_{c}}=\frac{1}{\alpha_{1}} \frac{\partial \mathrm{T}_{1}}{\partial t}
$$


for

$$
\left(0 \leq r \leq R_{B}, d<z<D\right)
$$

and where

$$
q^{\prime \prime}=0 \text { for } z<d \text { and } z>D
$$

and

$$
\frac{\partial^{2} \mathrm{~T}_{2}}{\partial \mathrm{r}^{2}}+\frac{1}{\mathrm{r}} \frac{\partial \mathrm{T}_{2}}{\partial \mathrm{r}}+\frac{\partial^{2} \mathrm{~T}_{2}}{\partial \mathrm{z}^{2}}=\frac{1}{\alpha_{2}} \frac{\partial \mathrm{T}_{2}}{\partial t}
$$

for

$$
\left(r \geq R_{B} \text { and any } z\right. \text { ) }
$$

and the boundary conditions

$$
\begin{aligned}
& \text { (a) } \mathrm{T}_{1}\left(\mathrm{r}, \mathrm{z}, \mathrm{o}^{+}\right)=\mathrm{T}_{2}\left(\mathrm{r}, \mathrm{z}, \mathrm{o}^{+}\right)=\mathrm{T}_{\mathrm{s}} \\
& \text { (b) } T_{1}(r, o, t)=T_{2}(r, o, t)=T_{s} \text {. } \\
& \text { (c) } \operatorname{Lim}_{z \rightarrow \infty} T_{1}(r, z, t)=\operatorname{Lim}_{z \rightarrow \infty} T_{2}(r, z, t)=T_{s} \\
& \text { (d) } \operatorname{Lim}_{r \rightarrow \infty} T_{2}(r, z, t)=T_{s} \\
& \text { (e) } T_{1}\left(R_{B}, z, t\right)=T_{2}\left(R_{B}, z, t\right) \\
& \text { (f) } k_{c} \frac{\partial T_{l}}{\partial r}\left(R_{B}, z, t\right)=k_{S} \frac{\partial T_{2}}{\partial r}\left(R_{B}, z, t\right) \\
& \text { (g) } \mathrm{T}_{1}(o, z, t)=\text { Finite. }
\end{aligned}
$$

Finite sine transformations of Equations (1) and (2) with respect to the Independent variable $\mathrm{Z}$ followed by a finite difference approximation results in the following system of equations which must be solved at each time step for a given $n:$

$$
\begin{gathered}
-\emptyset_{1} \bar{u}_{1, t}+4 \bar{u}_{2, t}=-\beta_{1} \bar{u}_{1, t-\Delta t}-Q_{l}(n) \\
\emptyset_{m} \bar{u}_{m-1, t}-\emptyset_{m} \bar{u}_{m, t}+\sigma_{m} \bar{u}_{m+1, t}=-\beta_{m} \bar{u}_{m, t-\Delta t}-Q_{m}(n) \\
\quad(\text { for } m=2,3, \ldots M I-2) \\
\emptyset_{M I-1} \bar{u}_{M l-1, t}-\bar{\emptyset}_{M l-1} \bar{u}_{M l-1, t}+\bar{\sigma}_{M l-1} \bar{u}_{M l-1, t}=-\beta_{M l-1} \bar{u}_{M l-1, t-\Delta t}-Q_{M l-1}(n)
\end{gathered}
$$




$$
\begin{aligned}
& \bar{\emptyset}_{M I+1} \bar{u}_{M I-1, t}-\bar{\emptyset}_{M I+1} \bar{u}_{M I+1, t}+\sigma_{M} \bar{u}_{M l+2, t}=-\beta_{M I+1} \bar{u}_{M I+1, t-\Delta t} \\
& \emptyset_{m} \bar{u}_{m-1, t}-\emptyset_{m} \bar{u}_{m, t}+\sigma_{m} \bar{u}_{m+1, t}=-\beta_{m} \bar{u}_{m, t-\Delta t} \\
& \text { ( for } \mathrm{m}=\mathrm{Ml}+2, \mathrm{Ml}+3, \ldots \mathrm{M}-2 \text { ) } \\
& \emptyset_{M-1} \bar{u}_{M-2, t}-\emptyset_{M-1} \bar{u}_{M-1, t}=-\beta_{M-1} \bar{u}_{M-1, t-\Delta t}
\end{aligned}
$$

where

$\mathrm{T}_{1}, \mathrm{~T}_{2}=$ Temperature within solidified waste and soil, respectively, ${ }^{\circ} \mathrm{F}$

$\mathrm{T}_{\mathbf{S}} \quad=$ Initial soil temperature, ${ }^{\circ} \mathrm{F}$

$\mathrm{r}, \mathrm{Z}=$ Radial and axial dimensions in cylindrical coordinates, $\mathrm{ft}$

$\mathrm{q}^{\prime \prime} \quad=$ Heat generation rate within solid waste, $\mathrm{Btu} / \mathrm{hr}-\mathrm{ft}^{3}$

$\mathrm{k}_{\mathrm{c}}, \mathrm{k}_{\mathrm{s}}=$ Thermal conductivities of solid waste and soll, respectively, Btu/hr-ft- ${ }^{\circ} \mathrm{F}$

$\mathrm{d}, \mathrm{D}=$ Depth beneath the soll surface of the top and bottom of the heat source, respectively, ft

$R_{B} \quad=$ Radius of the vessel containing the solid waste, $\mathrm{ft}$

$\mathrm{t} \quad=$ Time, hours

$\bar{u}_{m, t}=$ Transformed temperature at point $m$ at time $t,{ }^{\circ} \mathrm{F}$

M1 = Outermost nodal point in region $0<r<R_{B}$, integer

$\mathrm{M} \quad=$ Outermost nodal point in radial direction; integer

c $\quad=$ Mesh size multipller (a constant)

$\mathrm{L} \quad=$ That depth at which an increase, $\Delta \mathrm{L}$, results in a negligible change in the calculated temperature, $\mathrm{ft}$

$\mathrm{n} \quad=$ Finite transform parameter, integer

$\mathrm{m} \quad=\mathrm{A}$ nodal point in the radial direction, integer

$$
\begin{aligned}
Q_{m}(n) & =\frac{q^{\prime \prime}}{k_{c} c^{n}}\left[\cos \left(\frac{n \pi d}{L}\right)-\cos \left(\frac{n \pi D}{L}\right)\right]\left[\frac{c^{2 m-2}+c^{2 m-3}}{2}\right]\left[\Delta r_{1}\right]^{2} \\
\bar{\emptyset}_{M I} & =\emptyset_{M I}\left[\frac{c^{2}}{\left(1-c^{2}\right)}\right]
\end{aligned}
$$




$$
\begin{aligned}
& \emptyset_{\mathrm{Ml-1}}=\text { the quantity } \emptyset_{\mathrm{Ml-1}}-\left(\frac{\sigma_{\mathrm{Ml}-1} \mathrm{ck}_{\mathrm{c}}}{c \mathrm{k}_{\mathrm{c}}+\mathrm{k}_{\mathrm{S}}}\right) \\
& \bar{\sigma}_{\mathrm{MI-1}}=\text { the quantity } \frac{\emptyset_{\mathrm{Ml+l}}{ }^{\mathrm{ck}} \mathrm{c}_{\mathrm{c}}}{\mathrm{ck}_{\mathrm{c}}+\mathrm{k}_{\mathrm{S}}} \\
& \bar{\emptyset}_{\mathrm{Ml+l}}=\text { the quantity, } \emptyset_{\mathrm{Ml}+1}-\left(\frac{\emptyset_{\mathrm{Ml}+1} \mathrm{k}_{\mathrm{s}}}{c \mathrm{k}_{\mathrm{c}}+\mathrm{k}_{\mathrm{s}}}\right) \\
& \phi_{1}=\text { the quantity }\left[4.0+\beta_{1}+\left(\frac{n \pi \Delta r_{1}}{L}\right)^{2}\right] \\
& \beta_{m}=\left[\frac{c^{2 m-2}+c^{2 m-3}}{2 \alpha \Delta t}\right]\left[\Delta r_{l}\right]^{2}
\end{aligned}
$$

$\alpha=$ thermal diffusivity of calcine or soil (depending on context), $\mathrm{ft}^{2} / \mathrm{hr}$.

The system of Equations (3) was solved by the method of Thomas [30]. For the case of the solidiffed waste, the mathematical model was not validated by experimental data; however, based on the results from the simulated element [29], the calculated temperatures should reasonably approximate the actual temperatures in and surrounding the bin. The approach to steady state for a bin of specified size and internal heat generation rate is shown in Figure 26. Because of the large capacitance of the system, approximately two months are required for the steady temperatures to be reached. The system of Equations (3) can also be used to calculate the temperature as a function of position and time in a solidified waste in which the heat generation is decaying at a spectfled decreasing rate, as shown in Figure 27 for a theoretical MTR fuel waste cooled three years.

'I'he mathematical mudels proposed thus far are strictly applicable to a solidified waste which may be considered as a uniform heat source. At sufficiently high temperatures, the heat generating fission products would migrate into the thermally cooler regions of the calcine. These moving heat sources futher complicate any mathematical description of the transtent temperalures within the solidified waste. A study is underway to develop mathematical models for (a) predicting temperatures within a waste subjected to fission product migration and (b) calculating temperatures in a cylindrical vessel whioh is being filled

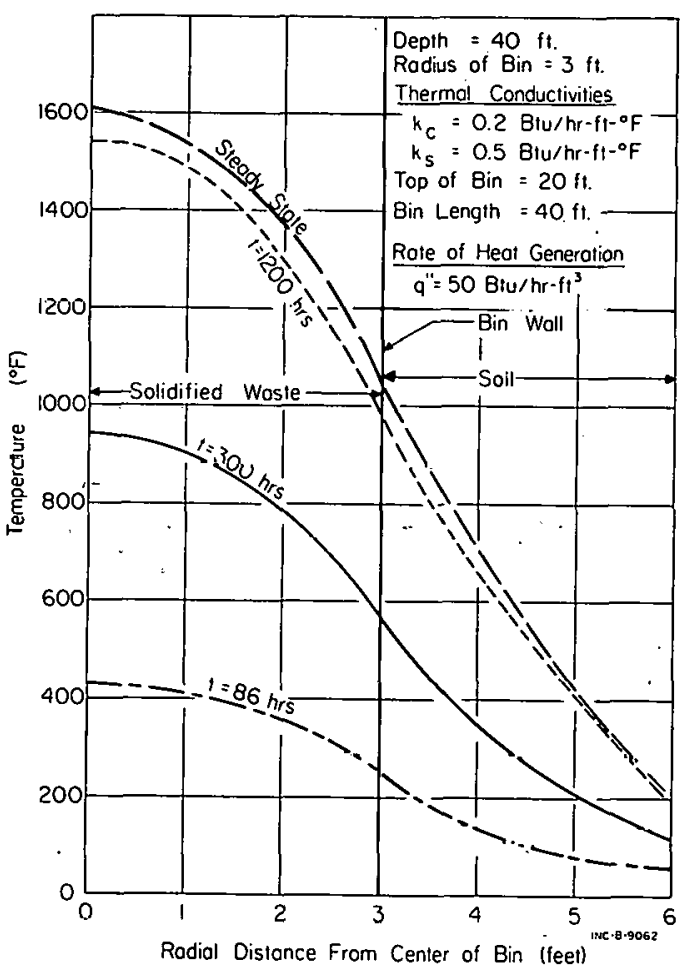

Fig. 26 Calculated transient temperatures in a buried cylindrical bin filled with solldified waste. 


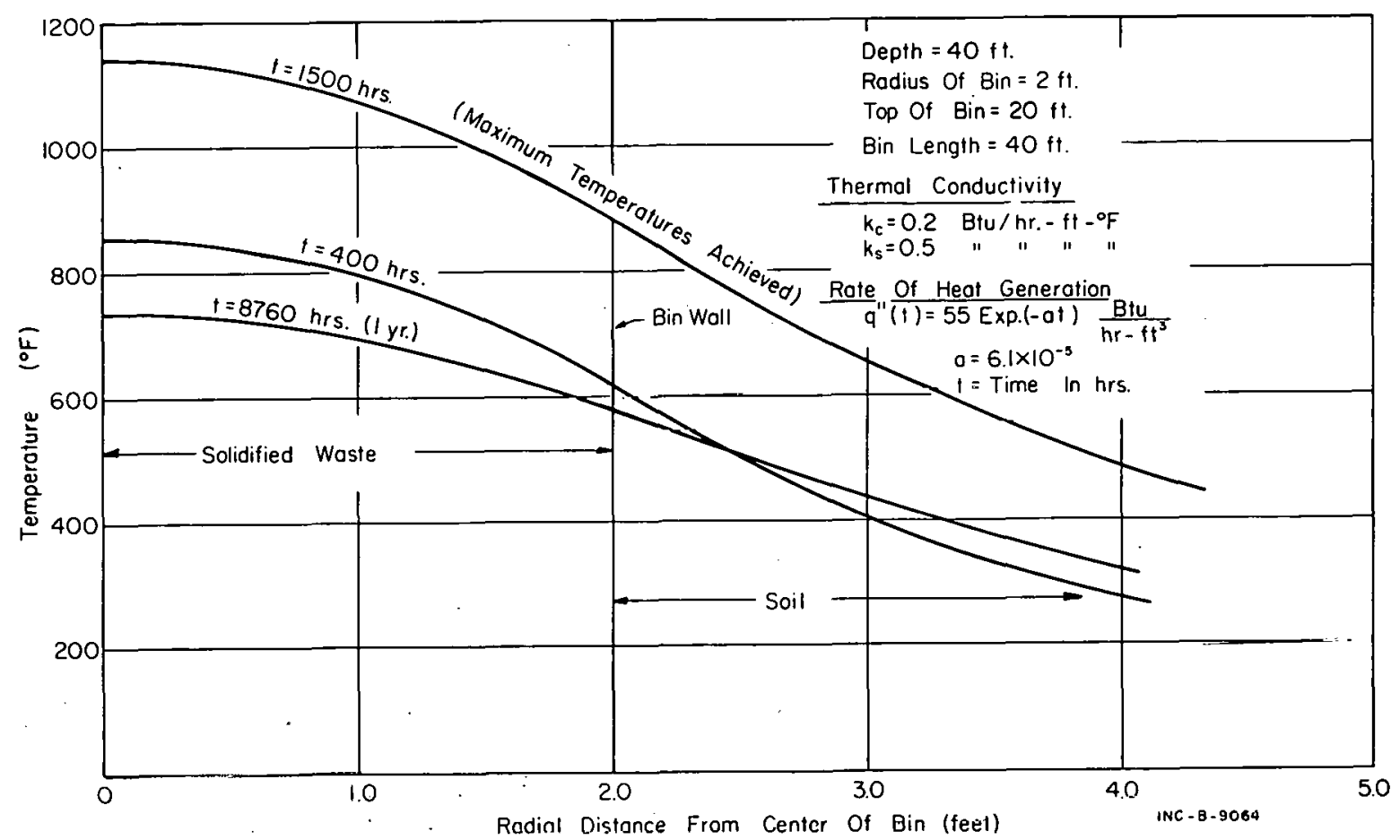

Fig. 27 Calculated transient temperatures in a buried cylindrical bin filled with unsolidified waste (theoretical MTR waste cooled three years).

with calcine. Diffusivity data for the various fission products, as required by the model, will be determined.

\subsection{Storage of Calcine at Elevated Temperatures}

(B. R. Dickey; Development Engineering Section)

Calcined wastes generated in the WCF during the first operating campaign are stored in cylindrical bins 10 feet in diameter and 20 feet high, contained in a concrete vault buried in the earth. Air flowing by natural convection within vertical, cylindrical annuli removes a portion of the decay heat while the remainder is transferred to the vault wall by thermal radiation and convection.

Calcine from current operations is being stored in cylindrical bins 12 feet in diameter and 40 feet high within a buried concrete vault. Heat is removed by conduction to the bin wall followed by convection and thermal radiation to the vault wall. These first and second generation bins were designed on the basis of maximum center-line temperatures of 400 and $700^{\circ} \mathrm{C}$, respectively. These limitations on maximum permissible temperatures result in added costs for storage facilities because of the required spacing of cooling surfaces for heat removal.

If the calcine could be stored at center-line temperatures near or at the fusion temperature of alumina $\left(2000^{\circ} \mathrm{C}\right)$, the greater thermal conductivity would permit a marked increase in the size of the storage container. This high temperature storage concept is based on the assumption that migrating or volatile fission products will condense within the cooler portions of the calcine. A mathematical study is now underway to determine the effects of fission product migration on temperatures within a stored mass of calcine. 
If wastes are to be stored at high temperatures (the present study will indicate the theoretical practicality) there are several major problem areas which must be investigated:

(1) The behavior patterns of migrating fission products must be determined experimentally. This involves the determination of the interrelationships between the fission product distribution and the temperature profiles for any proposed geometry.

(2) The significance of the corrosion to the containment vessel at the higher temperatures must be determined.

(3) Problems in the area of high temperature measurement for extended periods of time and the possibility of chemical reaction of the stored wastes with thermocouple materials must be studied.

Fluor Corporation conducted a conceptual design of a high-temperature storage facility in 1959-60. A cylindrical vessel, 12 feet in diameter and approximately 15 feet high, was to be filled with radioactive calcine having a rate of heat release of approximately $2.5 \mathrm{Btu} / \mathrm{lb}-\mathrm{hr}$. The project was abandoned because of (a) the large mass of calcine involved together with the many unknowns concerning fission product migration and volatilization, (b) uncertain loads on the off-gas cleanup equipment, (c) problems in high temperature measurement for extended periods of time, and (d) unavailability of calcine with a sufficiently high rate of heat generation.

4.41 Current Study Objectives. The current study involves, for the purpose of calculation, the situation where the central core of the stored mass is in a molten state. This assumption, however, is not a prediction that any melting would ever occur in stored calcine; fission product migration at lower temperatures may be sufficient to prevent fusion in a reasonable sized storage bin.

The major objectives of the calcine meltdown study are (a) the acquisition of data on the migration of fission products within solidified waste as a result of melting the central core, (b) determination of the experimental temperature profile in both the melt and the solid, and (c) development of adequate mathematical models for predicting the transient and steady state temperatures within the solid and melt, together with the movement of the "melt-line".

Design of any experimental equipment requires an analysis of the heat transfer characteristics of the reasonable geometries for the calcine containment vessel. The following cases were considered in the current mathematical study:

(1) Solid cylinder of finite length with perfectly insulated ends.

(a) Cylinder in a medium of constant temperature.

(b) Cylinder insulated on vertical surfaces.

(2) Solid cylinder of finite length; heat loss at ends, and placed in a medium of constant temperature. 
(3) Hollow cylinder of finite length with specified heat flux at the inner surface; heat loss at ends, and placed in a medium of constant temperature.

(4) Solid sphere of calcine.

(a) Placed in a constant temperature medium.

(b) Insulated sphere in a constant temperature medium.

(5) Hollow sphere placed in a constant temperature medium; specified flux at the inner surface.

(6) Parameters included in the analysis of each of the above cases were heat generation rate, thermal properties of the calcine, heat transfer coefficients, and the physical dimensions of the container.

Each of the above cases was evaluated by solving the applicable differential equation using the appropriate boundary conditions. Thus, for a cylinder, the temperature is given by

$$
\frac{d^{2} T}{d r^{2}}+\frac{1}{r} \frac{d T}{d r}+\frac{g^{\prime \prime}}{k_{c}}=0
$$

and the boundary conditions for the particular problem. For a sphere, the temperature is given by

$$
\frac{d^{2} T}{d r^{2}}+\frac{2}{r} \frac{d T}{d r}+\frac{q^{\prime \prime}}{k c}=0
$$

and the appropriate boundary conditions, where:

$$
\begin{aligned}
& \mathrm{T}=\text { temperature, }{ }^{\circ} \mathrm{F} \\
& \mathrm{r}=\text { radial distance, } \mathrm{ft} . \\
& \mathrm{q}^{\prime \prime}=\text { heat generation rate, Btu/hr-ft } 3 \\
& \mathrm{k}_{\mathrm{c}}=\text { thermal conductivity of calcine, } \mathrm{Btu} / \mathrm{hr}-\mathrm{ft}-{ }^{\circ} \mathrm{F}
\end{aligned}
$$

4.42 Results of Current Study. Calculation of temperaturce within the sulld cylindrical and spherical containers of calcine resulted in the following conclusions:

(1) Calcine decay heat (based on current values) alone cannot supply enough heat to melt the center of the calcine mass unless the container is very large $(R>5$ feet). 
(2) If high-efficiency insulation is used, the melting point of the calcine can be reached; however, the temperature drop through the calcine would be small. Fission product migration studies require a significant temperature drop through the calcine.

Since heat generation rates within existing calcine are too low to ensure self-melting within a mass of reasonable size, consideration is being given to melting through the use of internal resistance heaters or by induction heating. If possible, the outer surface of a cylindrical mass of calcine will be maintained at a constant temperature much less than the melting temperature, to provide both an adequate driving force for fission product migration into the "thermally" cold calcine and a convenient boundary condition for the mathematical model. Results of laboratory studies which elucidate the mechanisms of fission product migration will be incorporated into the mathematical model.

\subsection{Heat Transfer Across Vertical Cylindrical Air Gaps \\ (J. C. Petrie; Process Engineering Section) \\ (B. R. Dickey; Development Engineering Section)}

Correlations have been developed from results of experimental tests for determining the rate of heat transfer from a constant temperature cylindrical heat source surrounded by a concentric shroud; ie, the situation that would exist if shrouds were used around calcine storage bins. The air gap between the source and shroud was open at each end, allowing a net flow of ald through the system. The apparatus used to obtain the data has been described previously [1], and a tabulation of the data and heat transfer rates is shown in Table XXIV. A complete discussion of the experimental results and the methods of calculation has been published in IN-1110 [33]; results are summarized here.

The rate at which heat is transferred by free convection across a completely enclosed air gap has been previously correlated in terms of an effective thermal conductivity as a function of the Rayleigh number [31,32]. The net heat transferred by conduction and natural convection in the current study was determined by subtracting the heat transferred by radiation from the total heat leaving the source. Calculation of the radiative heat transfer from the source to the shroud was complicated, since the temperature increased with height along the shroud. Details of these calculations are given in IN-1110 [33].

A comparison of the effective thermal conductivities determined in this study with the effective conductivities for the case of a completely enclosed annulus is shown in Figure 28. The pseudo-effective thermal conductivity across an annulus open at the ends is approximately 1.2 times that of a completely enclosed air space. Correlations for natural convective heat transfer from vertical, cylindrical surfaces are valid in the presence of nearby surfaces down to an annular spacing of at least 0.35 inch. 
TABLE XXIV

HEAT BALANCE AT THE SURFACE OF THE HEATED CYLINDER

\begin{tabular}{|c|c|c|c|c|c|c|}
\hline \multirow[b]{2}{*}{$\begin{array}{c}\text { Source-to-Shroud } \\
\text { Annular Spacing } \\
\text { (insher) }\end{array}$} & \multirow[b]{2}{*}{$\begin{array}{c}\text { Total Heat } \\
\text { Input, QT } \\
(\mathrm{D}(\mathrm{u} / \mathrm{hr}) \\
\end{array}$} & \multirow[b]{2}{*}{$\begin{array}{c}\text { Source Wall } \\
\text { Tempera.tire } \\
\left({ }^{\circ} \mathrm{H}^{\prime}\right) \\
\end{array}$} & \multicolumn{2}{|c|}{$\begin{array}{l}\text { Radiation Heat } \\
\text { Transfer QR }\end{array}$} & \multicolumn{2}{|c|}{$\begin{array}{c}\text { Natural. } \\
\text { Convection } \\
\text { Heat Transfer } \\
Q_{C}\end{array}$} \\
\hline & & & $(\mathrm{Btu} / \mathrm{hr})$ & $(\%)$ & $(\mathrm{Btu} / \mathrm{hr})$ & $(\%)$ \\
\hline . & $\begin{array}{l}170 \\
360 \\
680 \\
760\end{array}$ & $\begin{array}{l}120 \\
201 \\
209 \\
225\end{array}$ & $\begin{array}{r}26 \\
95 \\
129 \\
178\end{array}$ & $\begin{array}{l}15 \\
26 \\
22 \\
24\end{array}$ & $\begin{array}{l}114 \\
265 \\
551 \\
582\end{array}$ & $\begin{array}{l}85 \\
74 \\
78 \\
76\end{array}$ \\
\hline 2.7 & $\begin{array}{r}360 \\
990 \\
1710 \\
2210 \\
3010 \\
3720\end{array}$ & $\begin{array}{l}145 \\
240 \\
325 \\
370 \\
460 \\
520\end{array}$ & $\begin{array}{r}103 \\
325 \\
617 \\
845 \\
1309 \\
1758\end{array}$ & $\begin{array}{l}29 \\
33 \\
36 \\
38 \\
43 \\
47\end{array}$ & $\begin{array}{r}257 \\
665 \\
1093 \\
1365 \\
1701 \\
1962\end{array}$ & $\begin{array}{l}71 \\
67 \\
64 \\
62 \\
57 \\
53\end{array}$ \\
\hline 6 & $\begin{array}{r}360 \\
550 \\
680 \\
1020 \\
1360 \\
1710\end{array}$ & $\begin{array}{l}140 \\
175 \\
195 \\
238 \\
275 \\
305\end{array}$ & $\begin{array}{l}103 \\
182 \\
236 \\
375 \\
500 \\
630\end{array}$ & $\begin{array}{l}29 \\
33 \\
35 \\
37 \\
36 \\
37\end{array}$ & $\begin{array}{r}257 \\
368 \\
444 \\
54 ' \\
860 \\
1080\end{array}$ & $\begin{array}{l}71 \\
67 \\
65 \\
6 " 3 \\
64 \\
63\end{array}$ \\
\hline$\cdot$ & $\begin{array}{r}170 \\
360 \\
680 \\
1090 \\
1360 \\
1710\end{array}$ & $\begin{array}{l}110 \\
135 \\
181 \\
220 \\
245 \\
275\end{array}$ & $\begin{array}{r}61 \\
115 \\
248 \\
385 \\
490 \\
624\end{array}$ & $\begin{array}{l}36 \\
32 \\
36 \\
34 \\
35 \\
36\end{array}$ & $\begin{array}{r}109 \\
245 \\
432 \\
705 \\
870 \\
1096\end{array}$ & $\begin{array}{l}64 \\
68 \\
64 \\
66 \\
65 \\
64\end{array}$ \\
\hline $\begin{array}{l}\text { Heat Transfer } \\
\text { Without a Shroud }\end{array}$ & $\begin{array}{r}550 \\
1020 \\
1590 \\
2390 \\
3420\end{array}$ & $\begin{array}{l}125 \\
160 \\
190 \\
240 \\
300\end{array}$ & $\begin{array}{r}365 \\
670 \\
1020 \\
1500 \\
2130\end{array}$ & $\begin{array}{l}66 \\
66 \\
64 \\
63 \\
63\end{array}$ & $\begin{array}{r}185 \\
350 \\
570 \\
890 \\
1290\end{array}$ & $\begin{array}{l}34 \\
34 \\
36 \\
37 \\
37\end{array}$ \\
\hline
\end{tabular}




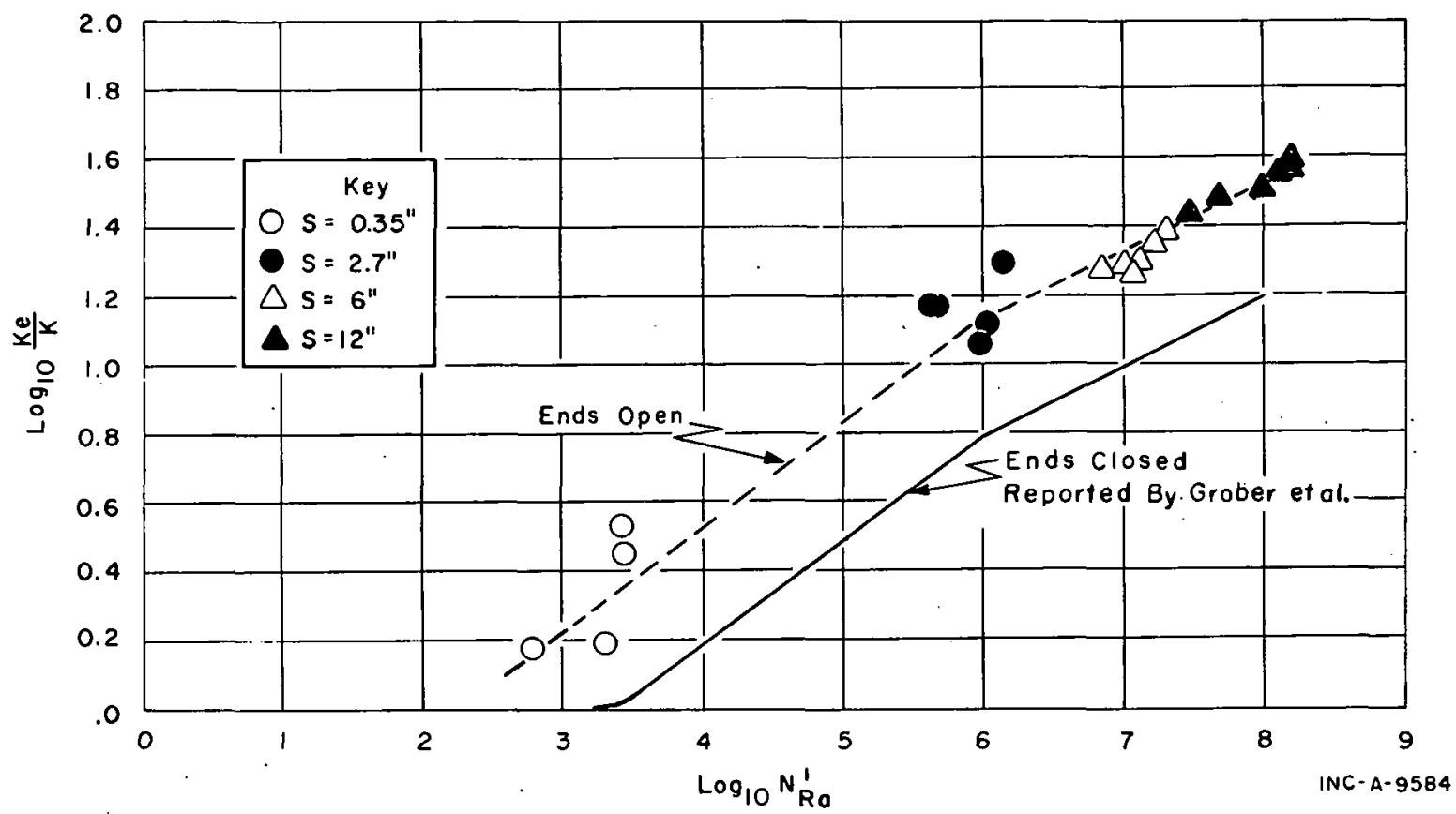

Fig. 28 Effective thermal conductivities across annular spaces as a function of the Rayleigh number.

\section{ADDITIONAL WASTE MANAGEMENT STUDIES}

\subsection{Removal and Recovery of Mercury from WCF Feed}

(M. W. Wilding; Chemistry Section)

In the future, it may be desirable to operate the WCF at higher calcination temperatures, in which case much of the mercuric oxide in the alumina bed may volatilize and be collected in the scrubbing solution stream. The mercury would be converted to soluble mercuric nitrate in the scrubbing solution and be recycled to the calciner, thus producing a buildup of mercury in the system. To prevent this, the mercury should be removed from the waste before calcination.

Laboratory studies indicate that it may be possible, and economically desirable, to reclaim mercury from waste solutions for reuse. An 85 percent solution of hydrazine hydrate, when added to synthetic aluminum nitrate waste [1.0 $\mathrm{M} \mathrm{HNO}_{3}, 1.6 \mathrm{M} \mathrm{Al}\left(\mathrm{NO}_{3}\right)_{3}, 0.02 \mathrm{M} \mathrm{Hg}\left(\mathrm{NO}_{3}\right)_{2}$, and $0.09 \mathrm{M} \mathrm{NaNO}_{3}$ ] at a 1.0 volume percent level, reduced essentially all of the mercuric ion in solution to the metal after three hours of boiling. At one volume of hydrazine hydrate per 100 volumes of waste solution, approximately eight cents worth of hydrazine would be used in processing the approximately 22 cents worth of mercury in one gallon of waste. The mercury could then be reused as a catalyst for the dissolution of aluminum alloy fuels. 


\subsection{Waste Blending Study}

(G. E. Lohse, J. L. Lockard; Process Engineering Section)

Wastes in storage at the ICPP vary in activity depending on the type of fuel from which the waste originated, the fuel irradiation time in the reactor, and the time since the fuel was discharged from the reactor. For economic reasons, the facility for storing solids calcined in the WCF was designed to contain solids having a heat generation rate of up to 0.4 Btu per hour per pound. To avoid wasting storage space by producing low heat generating waste, and to avoid damage by producing wastes that are too hot, it is frequently necessary to blend old and new waste to obtain.solfds with the desired heat generation rate. As future commitments are realized, numerous changes in ICPP and WCF processing schedules are anticipated; consequently, a FORTRANIV program has been written to update schedules rapidly. Currently, the program is being used to give a preliminary estimate of the activity level of the liquid waste that will remain after the termination of the current WCF campaign, and also to optimize the processing avallabllity of the WCF, as blending of future with current wastes is achieved. The activity level of future blends oould influence the design of the next solids storage facility. Ultimately the program may be used to guide the filling of the liquid storage tanks as well.

The program consists of the main routine and four subroutines for reading all the input data, for computing the blends, for indexing and sequencing tanks according to the heat generation rates and processing availability, and for determining the volume of liquid waste calcined, the volume and heat generation rate of the sollds produced, and the chemical composition of the waste. The

program has the capacity of 200 blending combinations from four different blending stocks, but it is limited to a total of 30 different tanks and ten heat generation decay curves. 


\section{LOFT ASSISTANCE PROGRAM}

The Chemical Technology Branch has several development studies underway in support of the Loss-of-Fluid Test (LOFT) at the National Reactor Testing Station. The LOFT project is the field duplication of a loss-of-coolant or maximum credible accident for a water-cooled reactor. As envisioned throughout this reporting period, this test consists of releasing the coolant deliberately from a 50-MW pressurized water reactor, thus permitting the fuel core to melt and release fission products into the reactor shell and containment building.

The specific development studies undertaken by this branch include (a) the evaluation of surface coatings and sealants for the interior of the containment shell, (b) the development of procedures for decontamination of the facility, (c) the development of a continuous fission product sampler-monitor for the containment atmosphere, (d) the evaluation of plateout samplers, and (e) the design construction, and operation of a fission product generation and containment unit to assist in evaluating the results of the preceding studies as well as to provide general support for the LOFT program. Progress in each of these areas is reported although all are continuing programs and none. has reached a state permitting final conclusions to be stated.

1.1 LOFT Coating and Elastomer Evaluation and Decontamination Studies (B. J. Newby, T. L. Evans, R. G. Butzman; Chemistry Section)

Studies are continuing to evaluate coating materials for the interior of the Loss-of-Fluid Test (LOFT) containment building and to develop decontamination methods for these coated surfaces. The ideal coating system for LOFT would have the following characteristics:

(1) Be typical of coatings existing in present and future reactor containment buildings

(2) Be resistant to conditions that might exist in the LOFT containment buildings

(3) Be sufficiently elastic to be able to contract and expand with its substrate as surfaces are heated and cooled

(4) Contain a primer that can be applied over slruclural steel by the vendor and can be covered with the finish coat later at a more convenient time when the steel is in place in the LOFT containment building

(5) Be a coating system that can be decontaminated from radioactivity.

Studies have been performed to find coating systems having these characteristics [a].

[a] The experimental evaluations of protective coatings and reagents reported here were done to obtain information on the performance of these materials in the specific applications and enrivonments listed. Any conclusions as to the relative merits of the materials apply only to the specific conditions mentioned. The fact that some materials were observed to be superior or inferior to others in these tests does not imply any general finding of superiority or inferiority. 
1.11 Coatings Typical of those in Existing Containment Buildings. An informal and limited survey of the practices in selection and specification of coatings for the interior of power reactor contalnment bulldings revealed that up to now little consideration has been given to the interaction of fission products released in a nuclear accident with the protective coating used. Since the protective coatings have been largely selected on the basis of general industrial criteria, eg, durability, appearance, and light reflectance, typical practice was found to involve a wide range of high quality coating systems. No national or industrywide standards are in use and, thus, several coating systems could be considered typical. Therefore, for the present study it has been assumed that a coating system having contamination and decontamination characteristics at about the midpoint of the spectrum of values experienced with the most common of the durable protective coatings would be representative of those used in the industry. For the LOFT experiment, of course, a coating with the best decontamination characteristics possible is desired.

1.12 Coatings Resistant to LOFT Containment Building Fnvironment. Conating systems applied to the interior surfaces of the LOFT containment building should be resistant to pressurized steam, gamma radiation, and solutions that might be sprayed on the coating system to decontaminate it. Some results of these tests have been reported previously $[1,16]$; more recent results are summarized in Table XXV. Coatings were considered to have the following:

(1) Satisfactory chemical resistance to a reagent if the reagent produced little or no effect on a coating submerged at $60^{\circ} \mathrm{C}$ for five days

(2) Questionable resistance if the coating was markedly affected between one and five days of submergence

\section{$\underline{\text { TABLE XXV }}$}

RESISTANCE OF COATINGS TO DECONTAMINANTS AND ENVIRONMTNTAL CONDITIONS PRESENT DURING THE IOTT TXTERIMTNT

\begin{tabular}{|c|c|c|c|c|c|c|c|c|c|c|}
\hline Test Rumber - & Finleh coat & Primer & $\begin{array}{c}\text { Finioh cost } \\
\text { Generic } \\
\text { Jype } \\
\end{array}$ & Substrate & 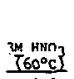 & 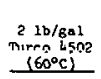 & 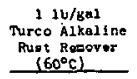 & 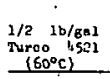 & $\begin{array}{r}\text { Resistance to } \\
\text { Preegur } 12 \text { ed Stean } \\
\left(30 \text { pois and } 133^{\circ}\right) \\
(3 \text { dangs) } \\
\end{array}$ & 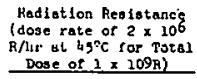 \\
\hline 1 & $\begin{array}{l}\text { Chemfant MP Mite } \\
\text { (Converter Catalyst } \\
\text { fumber } 46802 \text { ) }\end{array}$ & $\begin{array}{l}\text { Cheafost } \\
\text { E.P. Primer }\end{array}$ & Epoxy & Carbon Steel & $v(a)$ & $s[a]$ & $s$ & $\mathrm{~s}$ & $s$ & $\mathrm{~s}$ \\
\hline 2 & $\begin{array}{l}\text { Chemfast MP White } \\
\text { (Converter Catalyst } \\
\text { Sumber } 46802 \text { ) }\end{array}$ & Chen Zinc & Epoxy & Carbon Steel & u & $\mathbf{s}$ & $\mathbf{s}$ & $\mathbf{s}$ & $\mathbf{s}$ & s \\
\hline 3 & $\begin{array}{l}\text { Chemfast rP mite } \\
\text { (Converter Catalyst } \\
\text { Tuuber } 66802 \text { ) }\end{array}$ & $\begin{array}{l}\text { RE } 1370 \\
\text { Z1je FIch }\end{array}$ & Epoxy & Carbon Steel & v & $Q[a]$ & $\mathbf{s}$ & $\mathbf{s}$ & $u$ & -- \\
\hline 4 & 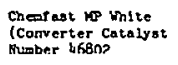 & Bone & Epory & Concrete & v & s & $\mathrm{s}$ & $\mathbf{s}$ & $\mathbf{s}$ & -- \\
\hline 5 & $\begin{array}{l}\text { Chearast MP thite } \\
\text { (Canverter Cataiyst } \\
\text { sumber LBBu, }\end{array}$ & Hone & Epoxy & Concrete & $u$ & $\mathbf{s}$ & s & $\mathbf{s}$ & v & --- \\
\hline 6 & Phenoline 360 & \begin{tabular}{c} 
Phenoline \\
\hdashline 69
\end{tabular} & $\begin{array}{l}\text { Modiried } \\
\text { Ptyenusise }\end{array}$ & Carbon steed & $\mathrm{u}$ & $\mathbf{s}$ & $\mathrm{s}$ & $\mathbf{s}$ & s & $\$$ \\
\hline$T$ & Tanclene & $\begin{array}{l}\text { Aluminum } \\
\text { Pr Laer }\end{array}$ & Epoxy & Carbon Steel & $u$ & $\mathbf{s}$ & $\mathrm{s}$ & $\mathbf{s}$ & $u$ & s \\
\hline 8 & Tonclene & $\begin{array}{l}\text { Aluminum } \\
\text { Primer }\end{array}$ & Epary & Aluse I num & $u$ & $\mathrm{u}$ & $u$ & s & $\mathbf{s}$ & -- \\
\hline 9 & Tans enese & $\operatorname{Phnpold~}_{306}$ & Apoxy & Carbon Etee1 & $v$ & c & 0 & 3 & $s$ & $s$ \\
\hline 10 & Epury 9-303-90 & nonte & epaxy & Sardoon steet & v & $a$ & $s$ & $\mathbf{s}$ & s & $\mathrm{s}$ \\
\hline 11 & Chemfant ox-1055 & $\begin{array}{l}\text { Chesrast } \\
\text { E.P. Priner }\end{array}$ & Epory & Carbon Steel & $\mathrm{v}$ & $\mathbf{s}$ & $\mathbf{s}$ & $\mathbf{s}$ & s & s \\
\hline 12 & Chemrsat ox-10s5 & Devron 600 & Eparg & Carbon Steel 1 & $y$ & s & $\mathrm{s}$ & s & u & $\mathbf{s}$ \\
\hline 13 & Phenol ine 302 & Pthenolline 300 & Modified & Carbon Steel & $\mathrm{s}$ & $\mathrm{s}$ & $\mathrm{s}$ & $\mathrm{s}$ & $\mathrm{s}$ & $s$ \\
\hline 24 & Plasite 7155 & Plasite 7155 & $\begin{array}{l}\text { Modified } \\
\text { Phenolle }\end{array}$ & Carbon Steel & $u$ & a & $\mathbf{s}$ & s & $\mathrm{s}$ & $\mathbf{s}$ \\
\hline
\end{tabular}


(3) Unsatisfactory resistance if the reagent produced a marked effect in less than one day of submergence.

Coatings were also considered to have a (a) satisfactory resistance to pressurized steam if exposure at $30 \mathrm{psig}\left(133^{\circ} \mathrm{C}\right)$ for three days produced little or no effect on the coating and (b) satisfactory resistance to radiation if a betagamma dose rate of about $2 \times 10^{6} \mathrm{R} / \mathrm{hr}$ at $45^{\circ} \mathrm{C}$, continued for a total dose of $10^{9} \mathrm{R}$, had little or no effect on the coating.

The resistance of a coating to physical and chemical tests may depend upon the substrate, primer, or converter (curing) catalyst used. Comparison of tests 7 and 8 of Table XXV indicates the influence of the substrate on the resistance of the coating system to chemicals. In this case the basic reagents probably diffused through the coating and reacted with the aluminum. Tests 1 and 3 demonstrate the dependence of the chemical resistance of coatings on the primer where either primer might be regarded as acceptable for ordinary use. The influence of the converter catalyst on resistance to pressurized steam, again a choice between apparant equals, is shown by tests 4 and 5 . Tests 7 and 8 illustrate the dependence of this property on substrate. Comparison of tests 2 with 3,11 with 12 , and 7 with 9 illustrates the dependence of steam resistance on the primer.

Phenoline 302 passed all the tests satisfactorily. Most of the coatings tested, however, would be adequate as a covering material for the inside of the LOFT containment building if resistance to the exposure conditions was the only consideration.

1.13 Elasticity of Coatings. Currently it is planned to have elastomer joints in the interior concrete surfaces of the LOFT containment building to allow the concrete surfaces to expand and contract with the outer steel shell of the building. Coatings applied over these joints must be sufficiently elastic to expand and contract with the elastomer without suffering damage. Since coated elastomers must be resistant to conditions that might exist in the building, a polyurethane, an epoxy, and a silicone rubber sealant were tested for their resistance to these conditions. The former two elastomers failed when exposed to $1 \times 10^{9} \mathrm{R}$. The bond between concrete and the polyurethane and silicone rubber elastomers had a tendency to fail under certain conditions but seemed to be satisfactory when covered with coatings. The epoxy elastomer was quite mobile at elevated temperature. When coatings were applied over these elastomers, the coatings cracked and peeled when the systems were heated and cooled. The silicone rubber elastomer was more suitable under conditions that might exist in the containment building than the other two systems. Incorporating woven glass fabric into coatings applied over the silicone elastomer allowed the coatings to expand and contract with the elastomer, when heated and cooled, without cracking and peeling. Figure 29 shows the failure of a coating containing no glass fabric when applied over two concrete blocks held together by a silicono elastumer and autoclaved for 24 hours at $30 \mathrm{psig}$ and $133^{\circ} \mathrm{C}$; also shown is the unaffected appearance of the same coating containing glass fabric applied over the same system and autoclaved for 72 hours at $30 \mathrm{psig}$ and $133^{\circ} \mathrm{C}$. The latter system was quenched every 24 hours placing additional strain on the coating. 


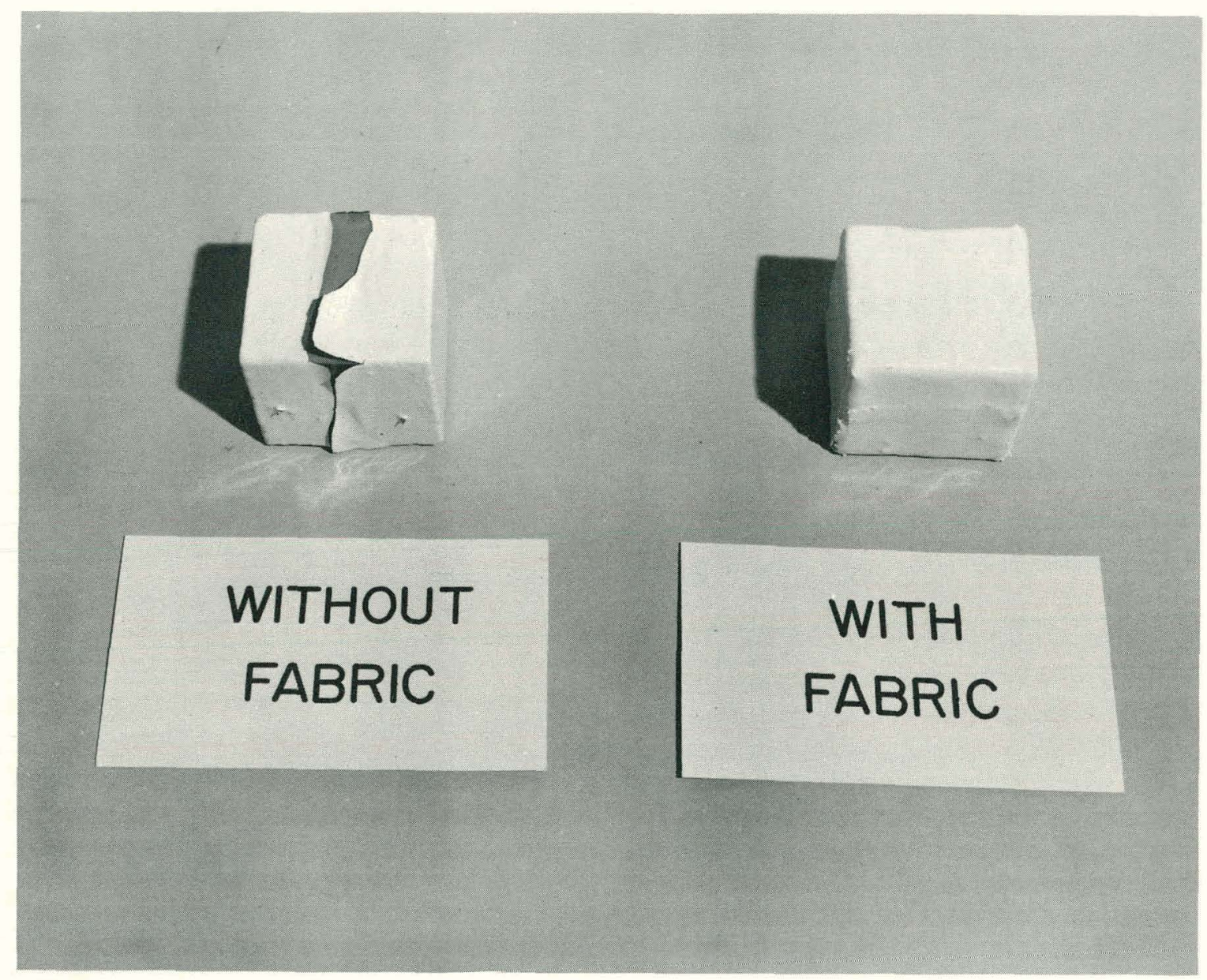

Fig. 29 Effect of pressurized steam on coatings with and without woven glass fabric applied over a silicone rubber elastomer.

1.14 Primers for Structural Steel. It is desirable that structural steel in the LOFT containment building be coated with a primer by the vendor and coated with a finish coat when the rest of the containment building is painted. Since these steel components will be primed by the vendor before the final LOFT coating system can be selected, the primer used on the steel must bc compatible with a variety of finish coatings. A primer is required that can remain uncovered for a long time interval before applying the finish coat, yet without adversely affecting adhesion between the primer and finish coats. Coating systems containing a number of primers supposedly meeting the latter requirement, wherein the primers were covered with a variety of finish coatings after the primers had bcen cured for a short time and for a year, are being tested for their resistance to chemical reagents, radiation, and pressurized steam. Results of testing systems containing a finish coating applied over a primer cured for a short time are shown in Table XXVI. Systems consisting of finish coats over their usual primers were tested to show how systems containing these finish coats should have reacted to the tests.

The Phenoline 368 primer was recommended for use on the steel components in the LOFT containment because of its fine compatability and good 


\begin{tabular}{|c|c|c|c|c|c|c|c|c|c|}
\hline \multirow[b]{2}{*}{ Finioh cost } & \multirow[b]{2}{*}{$\begin{array}{l}\text { Finioh Coat } \\
\text { Gener 1c Type }\end{array}$} & \multirow[b]{2}{*}{ Primer } & \multirow[b]{2}{*}{$\begin{array}{c}\text { Primer } \\
\text { Gener1cType }\end{array}$} & \multicolumn{4}{|c|}{ Chemical Resiatance } & \multirow[b]{2}{*}{$\begin{array}{c}\text { Reslatance to } \\
\text { Pressurized Steam } \\
\text { (30 psig } \\
\text { and } 13^{\circ} \mathrm{C} \\
\text { gor } 33_{\text {days }} \\
\end{array}$} & \multirow[b]{2}{*}{ 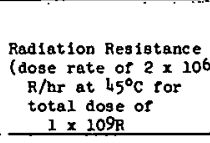 } \\
\hline & & & & $\begin{array}{l}\left.\frac{3 \mathrm{MHO}}{\mathrm{H}} \mathrm{HK} 0^{\circ} \mathrm{C}\right) \\
\end{array}$ & $\begin{array}{l}21 \mathrm{~b} / \mathrm{gal} \\
\text { Turco } 4502 \\
\left(60^{\circ} \mathrm{C}\right) \\
\end{array}$ & 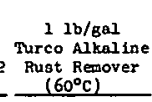 & $\begin{array}{l}1 / 21 \mathrm{~b} / \mathrm{gal} \\
\text { Turco } 4521 \\
\left(60^{\circ} \mathrm{C}\right) \\
\end{array}$ & & \\
\hline $\begin{array}{l}\text { Amercost } 66 \\
\text { Amercoat } 66 \\
\text { Amercoat } 66 \\
\text { Amercoat } 66\end{array}$ & $\begin{array}{l}\text { Epoxy } \\
\text { Epooxy } \\
\text { Epoxy } \\
\text { Epoxy }\end{array}$ & $\begin{array}{l}\text { Amercoat } 66(\mathrm{~g}) \\
\text { Amercost } 71 \\
\text { Chemfast E.p. Primer } \\
\text { Catha-Coat Formula } \\
300 \\
\text { Carbo Zine } 11\end{array}$ & $\begin{array}{l}\text { Epoxy } \\
\text { Epoxy } \\
\text { Epoxy } \\
\text { chemicalizy } \\
\text { cured zinc } \\
\text { silicate } \\
\text { Self cured }\end{array}$ & $\begin{array}{l}\mathbf{u}[\mathbf{b}] \\
\mathbf{u} \\
\mathbf{u} \\
\mathbf{u}\end{array}$ & $\begin{array}{l}\mathrm{s}[\mathrm{b}] \\
\mathrm{s} \\
\mathrm{s} \\
\mathrm{s}\end{array}$ & $\begin{array}{l}\mathrm{s} \\
\mathrm{s} \\
\mathrm{s} \\
\mathrm{s}\end{array}$ & $\begin{array}{l}\mathbf{s} \\
\mathbf{s} \\
\mathbf{s} \\
\mathbf{s}\end{array}$ & $\begin{array}{l}\mathrm{s} \\
\mathrm{s} \\
\mathrm{s} \\
\mathrm{s}\end{array}$ & $\begin{array}{l}\mathbf{s} \\
\mathbf{s} \\
\mathbf{s} \\
\mathbf{s}\end{array}$ \\
\hline Amercoat 66 & Epoxy & Carbo zinc $\mu$ & $\begin{array}{l}\text { Self cured } \\
\text { 21nc a1lleste }\end{array}$ & U & s & $\mathrm{s}$ & $\mathrm{s}$ & $s$ & $s$ \\
\hline $\begin{array}{l}\text { Amercoat } 66 \\
\text { Phenollne } 300\end{array}$ & $\begin{array}{l}\text { Epoxy } \\
\text { Molf1iled } \\
\text { Phenolic }\end{array}$ & $\begin{array}{l}\text { Phenol1ne } 368 \\
\text { Phenol1ne } 300(a)\end{array}$ & $\begin{array}{l}\text { Modified Phenolic } \\
\text { Modified Phenolic }\end{array}$ & v & $\begin{array}{c}\mathrm{s} \\
-\cdots\end{array}$ & $\begin{array}{c}\mathrm{s} \\
---\end{array}$ & $\begin{array}{l}\mathrm{s} \\
---\end{array}$ & $\begin{array}{l}0 \\
Q \\
u\end{array}$ & $\begin{array}{l}\text { s } \\
\text { s }\end{array}$ \\
\hline Phenoline 300 & Modifled & Amercost 71 & Epoxy & u & $\mathrm{s}$ & s & $s$ & v & s \\
\hline Phenoline 300 & Mod181ed & Chemfast E. P. Primer & Epoxy & v & u & Q & Q & u & $\mathrm{s}$ \\
\hline Phenollne 300 & $\begin{array}{l}\text { Penolic } \\
\text { Modled } \\
\text { Phenolic }\end{array}$ & $\begin{array}{c}\text { Catha-Coat Formula } \\
300\end{array}$ & $\begin{array}{l}\text { Chemically } \\
\text { cured zinc } \\
\text { ollicate }\end{array}$ & 9 & s & s & s & $u$ & s \\
\hline $\begin{array}{l}\text { Amercost } 33 \mathrm{HB} \\
\text { Amercost } 33 \mathrm{BB} \\
\text { Amercoat } 33 \mathrm{HB} \\
\text { Amercoot } 33 \mathrm{HB}\end{array}$ & 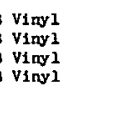 & $\begin{array}{l}\text { Amercoat } 86[\mathrm{~B}] \\
\text { Amercoat } 71 \\
\text { Chemfast E.P. Primer } \\
\text { Catha-coat Formula } \\
300\end{array}$ & $\begin{array}{l}\text { Epoxy } \\
\text { Epoxy } \\
\text { chemically } \\
\text { eured zine }\end{array}$ & 花 & $\begin{array}{l}\text { U } \\
\text { s } \\
\text { u } \\
u\end{array}$ & $\begin{array}{l}\text { s } \\
\text { s } \\
\text { s. } \\
\text { u. }\end{array}$ & $\begin{array}{l}\text { s } \\
\text { s } \\
\text { S } \\
\text { u }\end{array}$ & $\begin{array}{l}U \\
U \\
U \\
U \\
U\end{array}$ & $\begin{array}{l}\mathbf{s} \\
8 \\
\mathbf{s} \\
\mathbf{s}\end{array}$ \\
\hline Devoe Sx-1661 & Chlorinated & Chemfast E.P. Primer $[\mathbf{a}]$ & $\left.\right|_{\text {Epoxy }} ^{\text {sileste }}$ & $\mathrm{u}$ & u & Q & s & u & $\mathrm{s}$ \\
\hline Devoe SX-1661 & Chlorinated & Amercoat 71 & Epoxy & u & u & s & s & u & s \\
\hline Devoe $s x-1661$ & $\begin{array}{l}\text { Rubber } \\
\text { Chlorinated } \\
\text { Rubber }\end{array}$ & $\begin{array}{l}\text { Catha-Coat Pormula } \\
300\end{array}$ & $\begin{array}{l}\text { Chem1cally } \\
\text { cured zinc }\end{array}$ & u & u & u & v & u & $s$ \\
\hline $\begin{array}{l}\text { Devran } 600 \\
\text { Devran } 600 \\
\text { Devran } 600 \\
\text { Devran } 600\end{array}$ & $\begin{array}{l}\text { Epoxy } \\
\text { Eppoxy } \\
\text { Epoxy } \\
\text { Epoxy }\end{array}$ & 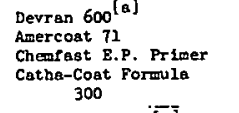 & $\begin{array}{l}\text { Epoxy } \\
\text { Epoxy } \\
\text { Epoxy } \\
\text { Chesically } \\
\text { cured } 210 \mathrm{c}\end{array}$ & $\begin{array}{l}u \\
u \\
u \\
u \\
u\end{array}$ & $\begin{array}{l}\mathbf{s} \\
\text { s } \\
Q \\
Q\end{array}$ & $\begin{array}{l}\mathbf{s} \\
\mathbf{s} \\
\mathbf{s} \\
\mathbf{s}\end{array}$ & $\begin{array}{l}\mathrm{s} \\
\mathrm{s} \\
\mathrm{s} \\
\mathrm{s}\end{array}$ & $\begin{array}{l}\text { u } \\
\mathbf{s} \\
\mathbf{s} \\
\mathbf{u}\end{array}$ & $\begin{array}{l}\mathrm{s} \\
\mathrm{s} \\
\mathrm{s} \\
\mathrm{s}\end{array}$ \\
\hline Phenoline 368 & 3 Modified & Pbenoline $368[\overline{[}[\overline{]}]$ & $\begin{array}{l}\text { Bll1ceste } \\
\text { Mod1f1ed } \\
\text { Phenolic }\end{array}$ & u & $\mathbf{s}$ & s & s & $\mathbf{s}$ & $\mathrm{s}$ \\
\hline 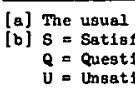 & $\begin{array}{l}\text { 1 primer for th } \\
\text { factory } \\
\text { Elonable } \\
\text { Elaractory }\end{array}$ & this aystem. & & & & & & & \\
\hline
\end{tabular}

performance with Phenoline 368 and Amercoat 66 finish coats. Amercoat 71 was shown to be a very versatile primer compatable with a wide range of different finish coats.

1.15 Contamination-Decontamination Behavior of Coatings. During this report period, mixed fission product behavior was obtained for coated carbon steel, and stainless steel surfaces contaminated in the Contamination-Decontaimination Experiment (CDE) Run 2. A description of the CDE equipment and operating conditions during CDE Run $\dot{z}$ is giveii in tho previous annual report[1]. Surfaces in CDE Run 2 received a higher deposition of activity than did those contaminated in CDE Run 1. Some fission products not detected on deposition coupons contaminated in CDE Run 1 were detected on coupons contaminated in CDE Run 2, and their behavior was studied. Table XXVII shows the fission products found on deposition coupons contaminated in CDE Run 2 , their relative abundance immediately after contamination, and decontamination factors obtained by a conventional decontamination method. As in CDE Run 1, greater than 90 percent of the activity found on the coupons contaminated in CDE Run 2 came from lodine-131. Coupons contaminated in CDE Run 2 were decontaminated by spraying them first with 2 pounds/gallon Turco 4502 at $80^{\circ} \mathrm{C}$ for 10 minutes using a spraying System Nozzle $1 / 4$ GG SS 6.5 at a pressure of 30 psig, rinsing with water, spraying with $1 / 2$ pound/gallon Turco 4521 under conditions identical to those used with Turco 4502, and rinsing with water. Although the iodine-131 decontamination factors obtained from coupons contaminated in CDE Run 2 were as poor as those obtained from coupons contaminated in CDE Run 1, the decontamination factors obtained for other fission 
CONTAMINATION-DECONTAMINATION BEHAVIOR OF MATERIALS CONTAMINATED IN CDE RUN 2 [a]

(Zero decay time unless otherwise indicated

\begin{tabular}{|c|c|c|c|c|c|c|c|c|c|c|c|c|c|c|c|c|c|c|c|c|}
\hline \multirow[b]{2}{*}{ mater1sal } & \multicolumn{2}{|c|}{$\begin{array}{l}\text { Groso Garmo Activity at } \\
10 \mathrm{~cm} \text { and } 16 \text { day decay tido }\end{array}$} & \multicolumn{2}{|c|}{$I-13$} & \multicolumn{2}{|l|}{$\mathrm{Te}-132$} & \multicolumn{2}{|l|}{ I-132 } & \multicolumn{2}{|l|}{$x c-92$} & \multicolumn{2}{|l|}{ Mo-92 } & \multicolumn{2}{|c|}{$\mathrm{Ba}-140$} & \multicolumn{2}{|l|}{ LA-140 } & \multicolumn{2}{|c|}{ PQN-103 } & \multicolumn{2}{|c|}{$\mathrm{C}_{8-137}$} \\
\hline & $\begin{array}{l}\text { Contansinatican } \\
\text { in } \\
\operatorname{ctg} / 100 \\
(x, 108) \\
\end{array}$ & $\begin{array}{l}\text { Decantanination } \\
\text { Pactor } \\
\text { (D.F.) } \\
\end{array}$ & 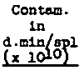 & & 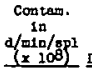 & & 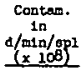 & & 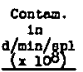 & & $\begin{array}{c}\text { Contas. } \\
10 \\
\alpha / 10 / 8 p)^{2} \\
(x \quad 108)^{2}\end{array}$ & & 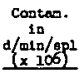 & & 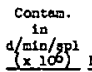 & & 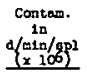 & & 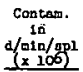 & \\
\hline Amercoat 66 & 4.4 & 2.8 & 10.3 & 4.5 & 7.5 & 33 & 5.8 & 45 & 2.7 & 18 & 5.5 & 40 & 3.6 & 440 & 3.29 & 960 & 1.8 & 146 & 2.0 & $\cdots$ \\
\hline Pbenol1ce 309 & 1.6 & 9.4 & 4.3 & 7.7 & 8.5 & 236 & 3.0 & 62 & 2.3 & 52 & 4.4 & 105 & 4.4 & 125 & 6.5 & 281 & 3.8 & 103 & 4.0 & 26 \\
\hline $\begin{array}{l}\text { Carbol1ne Epaxy } \\
\qquad 150\end{array}$ & 4.6 & 5.9 & 4.8 & 4.9 & $\cdots$ & $\cdots$ & $\cdots$ & $\cdots$ & $\cdots$ & $\cdots$ & $\cdots$ & $\cdots$ & $\cdots$ & $\cdots$ & $\cdots$ & $\cdots$ & $\cdots$ & $\cdots$ & $\cdots$ & $\cdots$ \\
\hline Devran 600 & 3.6 & 5.6 & 6.0 & 5.3 & $\cdots$ & $\cdots$ & $\cdots$ & $\cdots$ & $\cdots$ & $\cdots$ & -. & $\cdots$ & $\cdots$ & $\cdots$ & $\cdots$ & $\cdots$ & $\cdots$ & $\cdots$ & $\cdots$ & $\cdots$ \\
\hline Doble Polvcote & 2.1 & 5.7 & 3.7 & 5.6 & $-\cdot-$ & $\cdots$ & $\cdots$ & $\cdots$ & $\cdots$ & $\cdots$ & $\cdots$ & $\cdots$ & $\cdots$ & $\cdots$ & -- & $\cdots$ & $\cdots$ & $\cdots$ & $\cdots$ & $\cdots$ \\
\hline Plaelte 7155 & 3.4 & 8.0 & 5.7 & 7.0 & $\cdots$ & $\cdots$ & $\cdots$ & $\cdots$ & $\cdots$ & $\cdots$ & $\cdots$ & --- & -- & $\cdots$ & $\cdots$ & $\cdots$ & $\cdots$ & --- & $\cdots$ & --- \\
\hline Contam Afrix Perw & 6.0 & 3.8 & 10.2 & 3.7 & $\cdots$ & $\cdots$ & -.. & $\cdots$ & $\cdots$ & $\cdots$ & $--\cdot$ & $\cdots$ & $\cdots$ & $\cdots$ & $\cdots$ & ... & $\cdots$ & $\therefore$ & $\cdots$ & $\cdots$ \\
\hline Devos $\$ \mathrm{sx}-1661$ & 1.9 & 3.8 & 3.1 & 3.6 & $\cdots$ & $\cdots$ & $\cdots$ & $\cdots$ & $\cdots$ & --- & $\cdots$ & -- & -- & $\cdots$ & $\cdots$ & $\cdots$ & $\cdots$ & $\cdots$ & --- & $\cdots$ \\
\hline Carbog1es 1600 & 2.3 & 5.3 & 3.8 & 5.0 & $\cdots$ & $\cdots$ & $\cdots$ & $\cdots$ & $\cdots$ & --- & $--\cdot$ & $\cdots$ & $\cdots$ & $\cdots$ & $\cdots$ & $\cdots$ & $\cdots$ & $\cdots$ & $\cdots$ & $\cdots$ \\
\hline Carbol1ae $8-15$ & 6.3 & 2.9 & 10.8 & 2.9 & $\cdots$ & $\cdots$ & --- & $\cdots$ & $\cdots$ & $\cdots$ & $\cdots$ & -- & -- & $\cdots$ & $\cdots$ & $\cdots$ & $\cdots$ & $\cdots$ & $\div-$ & $\cdots$ \\
\hline $\begin{array}{l}\text { Stainleas steel } \\
304\end{array}$ & 0.46 & 900 & $0.13=$ & 200 & $\cdots$ & $\cdots$ & $\cdots$ & --. & $\cdots$ & ... & $\ldots$ & $\cdots$ & $\cdots$ & $\cdots$ & --. & $\cdots$ & $\cdots$ & $\cdots$ & $\cdots$ & $\cdots$ \\
\hline Carbon Steel & 3.7 & 280 & 6.0 & 312 & $\cdots$ & $\cdots$ & --- & --- & $\cdots$ & $\cdots$ & $\cdots$ & $\cdots$ & $\cdots$ & -- & $\cdots$ & $\cdots$ & $\cdots$ & ..- & & $\cdots$ \\
\hline
\end{tabular}

products were much better. The decontamination reagent system used in CDE Run 2 (Turco 4502 - Turco 4521) was more effective for fission products other than lodine than the system used in CDE Run 1 (nitric acid - Turco Alkaline Rust Remover). The effectiveness of the Turco 4502-Turco 4521 combination in removing lodine -131 from coupons contaminated in CDE Run 2 was tested against the effectiveness of 2 pound/gallon Turco $4502-1 / 2$ pound/gallon oxalic acid and also 2 pound/gallon Turco $4502-1 / 2$ pound/gallon RD16F (a decontamination) reagent manufactured by General Dynamics). While there was not much difference in the effectiveness of the three different combinations in removing iodine, Turco 4502-oxalic acid was slightly more effective than Turco 4502Turco 4521 which in turn was slightly more effective than Turco 4502-RD16F. The time that a coating is allowed to cure (between 10 days and $7-1 / 2$ months) was found to have little effect on its contamination-decontamination behavior.

Currently there appear to he four alternatc metluds for decontaminating tìe luslule coated surfaces of containmont buildings:

(1) Spray surfaces for a short time with an effective decontamination reagent combination and obtain the remaining decontamination needed hy taking advantage of lodine-131 decay.

(2) Use pressurized steam.

(3) Use chemically strippable coating systems.

(4) Corrode coated surfaces away by prolonged spraying with an effective decontamination reagent combination.

(1) Use of Short Spraying Time plus Iodine-131 Decay. It has been calculated that the inside of the LOFT bullding must be decontaminated by a factor of $10^{3}$ in order to gain limited access into the building after the LOFT experiment. A decontamination factor of no more than 10 (see Table XXVII) could be obtained by spraying coated surfaces with the best decontamination reagent combination. The remaining decontamination needed could be obtained by relying on fission product decay if time needed to obtain decontamination was 
not important. As seen in Table XXVII, iodine-131 has the longest half life of the major fission products that were released in CDE Run 2. To obtain an iodine-131 decontamination factor of $10^{3}$ would take 80 days. Iodine-131 has been found as the major fission product on coated coupons 120 days after being contaminated in the CDE.

(2) Use of Pressurized Steam. Previous work[16] has shown that pressurized steam (at $40 \mathrm{psig}$ and $140^{\circ} \mathrm{C}$ ) effectively removed molecular lodine from certain organic protective coatings contaminated at $40^{\circ} \mathrm{C}$ and atmospheric pressure in the presence of molsture. This remains a potential mode of decontamination for the interior of the containment building.

(3) Use of Chemically Strippable Coating Systems. The concept of strippable and corrodible coating systems is illustrated in Figure 30 . Such systems would consist of a permanent base coating containing glass cloth to protect the substrate (concrete containing silicone rubber expansion joints) and an expendable outer coat which can be removed along with the contamination. In the strippable coating system the outer coating would be removed by stripping (rapid dissolution) with a chemical reagent; in the corrodible coating system the outer coating would be corroded away by spraying with decontaminating reagents for long periods of time.

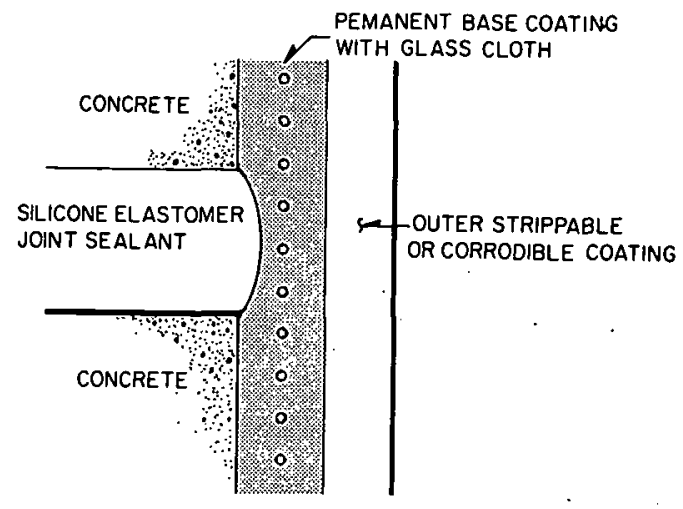

The top coat (strippable coat) should Fig. 30 Enlarged view of an expansion joint (a) be impermeable to fission products wall.

that will be present in the containment (especially to lodine), (b) be typical of conventional coatings in its contamination properties, (c) be readily removable with a solvent, and (d) be fairly resistant to steam. Systems recommended by manufactures and by our own experience as having the desired characteristics were scoped in the laboratory using molecular iodine as the contaminant; systems giving the best results were studied further in the CDE using mixed fission product contamination. A lutal of 21 different strippable coatings was studied. In both the laboratory and the $\mathrm{CDE}$, coatings were contaminated in the presence of steam at about $22 \mathrm{psig}$ and allowed to remain in the presence of. fission products and steam for 24 hours during which time the steam pressure decayed from 22 to 5 psig. Coupons were then sprayed for ten minutes at various temperatures with a number of stripping reagents, or sprayed a short time with a reagent, the reagent allowed to remain on the coupon for about ten minutes, and then rinsed off with water at $80^{\circ} \mathrm{C}$. The system giving the best results was Turco 5302 coating over Amercoat 66 undercoat; this was stripped with isophorone at $70^{\circ} \mathrm{C}$ for ten minutes. The Turoo 5302 coating will be studied in more detail. Many of the strippable coatings studied had the desirable characteristics of being typical of conventional coatings in their contamination properties, being readily removed with the appropriate reagent, and being sufficiently resistant to steam. None of the strippable coatings studied, however, were sufficiently impervious to iodine penetration. It might be possible to improve this characteristic by using thioker coatings or by incorporating a material into 
the coatings that will react with iodine. However, developments of the latter sort are not within the scope of the present program.

(4) Use of Corrodible Coating Systems. Coatings (together with fission products) can be corroded or removed from their substrate in a controlled manner by alternately spraying with an alkaline permanganate reagent and an organic complexing reagent, sodium bisulfite, or Turco Alkaline Rust Remover (for periods of from $1 / 2$ to 4 hours with each reagent) at $80^{\circ} \mathrm{C}$, continued for long periods of time ( 4 to 16 hours total spraying time). The coatings come off as small particles (the larger particles being of the order of $1 / 16$ inch across their longest dimension) and can also be removed (although more slowly than if sprayed) if solution can be made to run over the surface. This process is not entirely an erosion process since spraying the coatings with water at $80^{\circ} \mathrm{C}$ for greater than 16 hours does not erode away surfaces of the coatings tested. Thus, a decontaminable coating system applicable to LOFT might consist of a permanent undercoat with woven glass fabric embedded in it to protert the substrate, and a corrndible outer coating that can be removed along with contamination. Coatings that respond well to removal by corrosion with an alkaline permanganate reagent alternated with ailuthur reagent are Phenoline 302, Phenoline 368, Ejpoxy S-303-50, and Plasite 7155.

The corrodible coating systems suffer from the same weakness inherent in the strippable coating systems; in both systems lodine can penetrate through the removable coating and contaminate the permanent undercoat. In the corrodible system, however, a layer of the undercoat can be also removed for further decontamination without damaging the undercoat system remaining beyond repair. Also, the best corrodible coatings tested seem to be more impervious to iodine penetration than do the best strippable coatings.

Iodine decontamination factors of the order of $10^{2}$ have been obtained by alternately spraying a system consisting of Phenoline 302 over Amercoat 66 , containing embedded woven glass fabric, with 2 pounds/gallon Turco 4502 and $1 / 2$ pound/gallon oxalte anid for $1 / 2$-hour perlods until a total spraying time of four hours was used. This syotem was contaminated in the laboratory in the presence of steam simulating $\mathrm{CDE}$ operating conditions. Studies will be continued to select a corrodible coating and a permanent undercoat for a corrodible coating system, and to determine whether Turco 4521, Turco Alkaline Rust Remover, oxalic acid, or sodium bisulfite would be the best reagent to be used in combination with an alkaline permanganate reagent.

A modified version of the corrodible coating system offering merit consists of (a) spraying a thixotropic stripping reagent (such as Turco EPO-GON Thick or Turco Jet Strip 5292) on a corrodible coating system; (b) allowing the reagent to remain on the coating system for a ehort time; and (c) rinsing off the reagent, a layer of coating, and fission products with hot water. It was however, difficult to control coating removal with the two Turco stripping reagents mentioned. If the reagents were allowed to remain on the coatings sufficiently long to obtain acceptable decontamination ( $D F>10)$, the reagents would penetrate to the substrate and remove largc sectiuns of undercoat and corrodible coating; if the reagents were allowed to remain on the coating only a short time to control coating removal, poor decontamination was obtained $(D F \approx 2$ ). The reagents also left a slime on the coatings which might prevent repainting. 
The use of decontamination reagents in a thixotropic form, while potentially valuable because of the possibility of reducing waste volumes, would require additional development work.

\subsection{The Penetration of Iodine Into Protective Coatings}

(R. R. Hammer, B. J. Newby; Chemistry Section)

Under loss-of-coolant accident conditions in a pressurized water reactor, short lived fission products may be released to the atmosphere of the reactor containment building. The behavior of lodine under these conditions is of prime importance since it may represent more than 90 percent of the nonrare gas fission products released from the reactor vessel. In the course of the evaluation program for the protective coatings for LOFT[1] (Loss-of-Fluid Test), it was discovered that iodine, released as $\mathrm{I}_{2}$ in experimental studies, penetrated deeply into all of the protective coatings studied. In order to determine the impact of this penetration on the feasibility of decontamination of the protective coatings after a loss-of-coolant accident, quantitative data for the amount of penetration as a function of depth were obtained[a]. From other decontamination studies it was learned that the penetration of iodine was, at least in part, reversible [b]. Because of the importance of the phenomenon: of penetration to both the contamination and decontamination aspects of the loss-of-coolant accident, it appeared desirable to fit the experimental data for the penetration to a mathematical model so that extrapolation of the data would be possible. This was done earlier with reasonable success using a few sets of experimental data on two different coatings and a simple analytical approach. Using the solution of Fick's second law for unidirectional diffusion in a semi-infinite solid, diffusivities of the order of $10^{-9} \mathrm{~cm}^{2}-\mathrm{sec}^{-1}$ were calculated[c].

Recent studies on the penetration of lodine into protective coatings characteristic of those used in reactor contalnment buildings have been reported in IN-1095 [34] with the following generalized findings:

(1) Penetration of fodine occurs with the four types of paint cuatings tcotod, opoxy, vinyl, chlorinated rubber, and phenolic

(2) The degree of penetration is associated with the temperature of the coating and its physical state.

The previous model for unidirectional diffusion in a semi-infinite solid adequalely describes the penetration of lodine into these coatings to thicknesses as great as $0.25 \mathrm{~mm}$. Differences in exposure times of from 6 to 150 minutes, and in storage times between exposure and examination of from one to 312 hours, did not affect the observed diffusivity values by more than a factor of three. In general, the diffusivity increased with temperature, with two coatings showing sharp increases in diffusivity as their softening points were passed. The scale up of activity on protective coatings from laboratory studies to CDE gave calculated results for two coatings in CDE Runs 1 and 2 in good agreement with the measured values.

[a] See page 76 of Reference 1

[b] See page 77 of Reference 1

[c] Jee pago 80 of Reference 1 


\subsection{Contamination-Decontamination Experiment}

(L. T. Lakey, D. E. Black, W. A. Freeby, W. P. Palica; Development Engineering Section)

The Contamination-Decontamination Experiment was installed to augment the Loss-of-Fluid Test Assistance Studies being conducted at the ICPP. In the CDE, high-level fission product aerosols are produced under conditions simulating those anticipated in the LOFT. The fission product aerosol is generated by melting a small, highly irradiated and short-cooled fuel capsule in the presence of steam, using a radio-frequency induction furnace. The fission products released are transported by the steam to a simulated containmentshell. These fission product aerosols are used in studies of contamination, and decontamination of various protective coatings and equipment, in testing of various LOFT sampling devices, and for the development of analytical methods for the LOFT.

Four tests have been made in the CDE to date. Contamination of coupons for coating and decontamination studics was emphasjzed in the first two runs; emphasis was shlfted to testing of the LOFT plateout and gas-particulate capsule simplers in the third and fourth runs. The latter two tests were conducted in the CDE during the current fiscal year; Run 3 was made in Oclober, 1966 and Run 4 In March, 1967. A description of the CDE and a summary of the current year's results are summarized in the following sections.

1.31 Description and Operation of Equipment. The CDE, as shown in Figure 31, contains two major elements: an induction furnace for melting the fuel pin

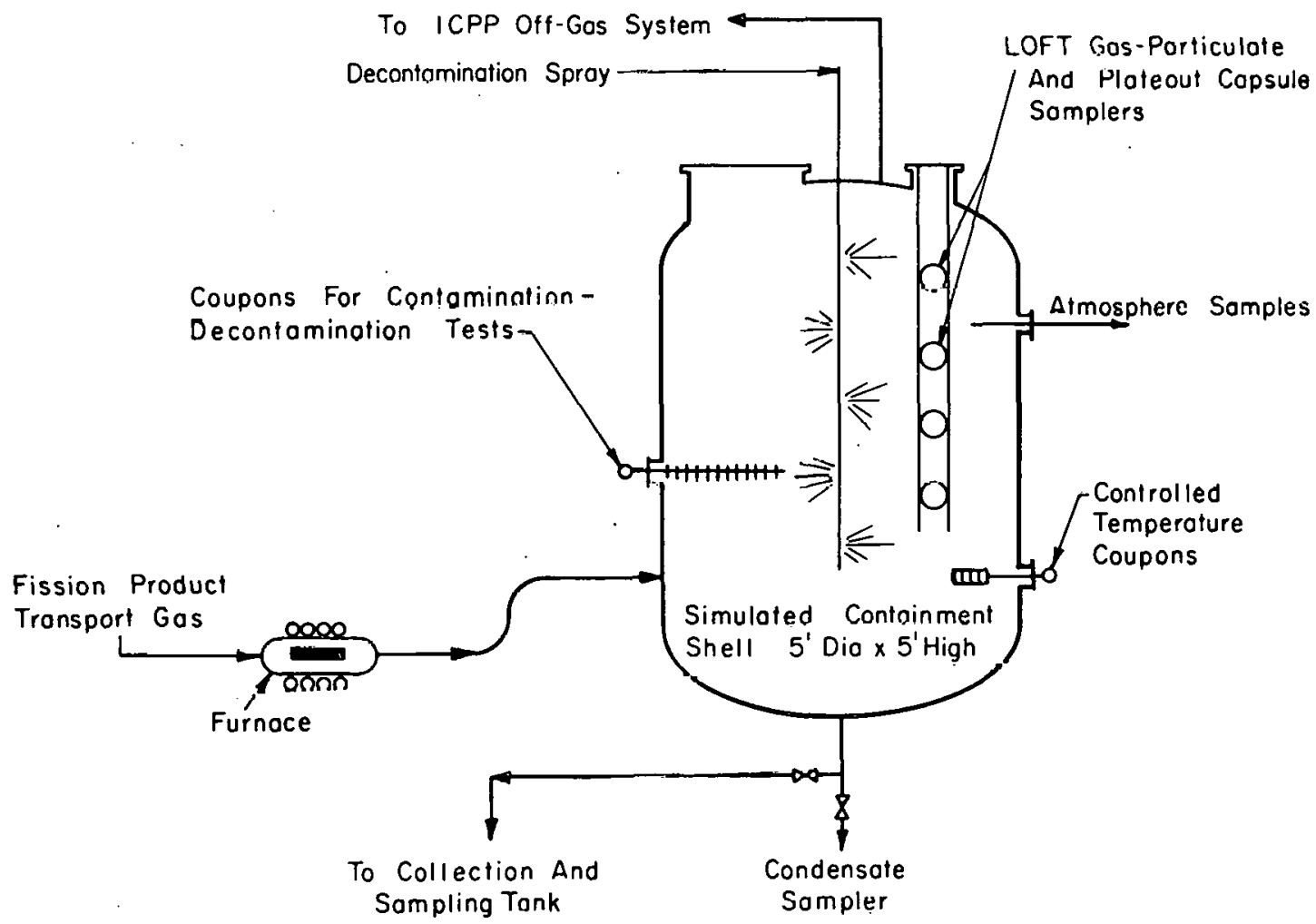

Fig. 31 Schematic flow sheet of the Contamination-Decontamination Experiment. 
and a simulated containment vessel. Nozzles, sampling devices, and other test equipment are provided in the containment vessel for inserting coupons to be contaminated, for sampling the containment atmosphere and condensate, and for decontaminating the vessel. The equipment comprising the induction and containment vessel systems was described previously[1] except that the induction furnace and the furnace coupling system were redesigned after Run 3 to eliminate stresses resulting from misalignment and by molten fuel particles spattering on the quartz furnace. In Runs, 1,2, and 3, the fuel pin was placed in a 200-gram bed of powdered $\mathrm{UO}_{2}$ inside the quartz tube for melting. Beginning with Run 4, a quartz sleeve and boat were used to hold the fuel pin inside the furnace tube. About 20 grams of powdered $\mathrm{UO}_{2}$ are placed in the boat before the fuel pin is loaded. The sleeve prevents the molten fuel from contacting the furnace tube, and the boat reduces the amount of $\mathrm{UO}_{2}$ bed material needed. Guides and stops are built into the various furnace assembly pieces so they can be assembled remotely. The furnace coupling system, shown in Figure 32, was made more rigid to prevent misalignment and the consequent mechanical stresses on the furnace tube when the couplings were being tightened remotely. The coupling system was designed so that the inlet section of the transport line can be moved horizontally through a distance of 26 inches to enable the furnace to be loaded and coupled to the transport line remotely with manipulators.

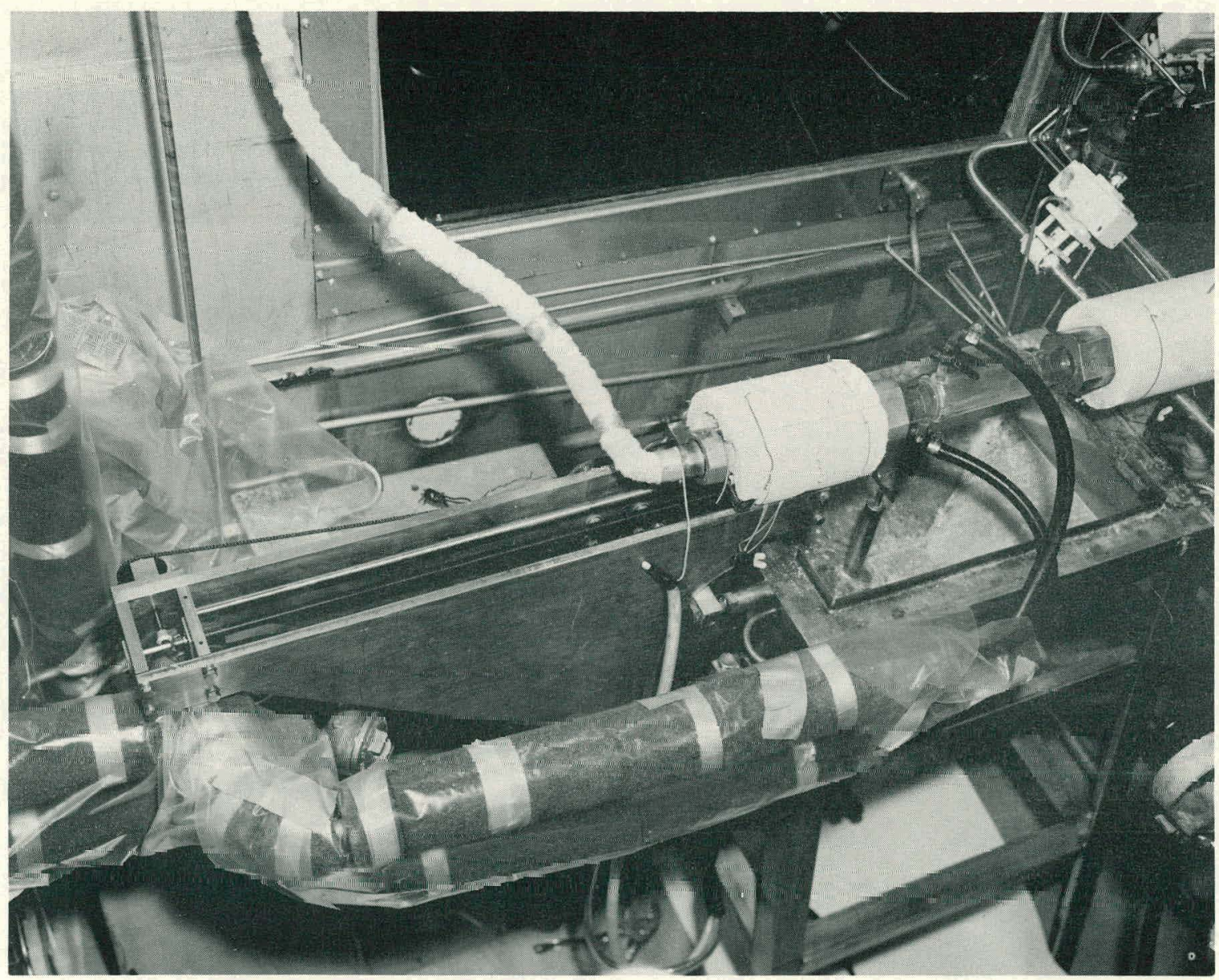

Fig, 32 Furnace assembly system as modified for CDE Run 4. 
The fission product aerosols are generated by melting Zircaloy-clad fuel pins (9/16-inch diameter by 3-1/2 inches long) containing enriched $\mathrm{UO}_{2}$ pellets. The fuel pins are encased in aluminum jackets to reduce the temperature of the pins during irradiation. Following irradiation in the Materials Testing Reactor, a fuel pin is transported to the ICPP Hot Pilot Plant where the aluminum jacket is dissolved in caustic. The fuel pin is then inserted into the quartz furnace tube and melted by induction heating. During the meltdown, steam is passed over the fuel pin to carry the fission products into the simulated containment vessel where the environmental conditions and atmospheric composition are adjusted to match the anticipated LOFT containment building conditions. After melting of the fuel pin is complete, the containment vessel is isolated, and the temperature of the containment vessel atmosphere is gradually reduced to ambient temperature over a 24-hour period to match the expected decay of the LOFT containment building temperature. During this period, samples of the containment atmosphere and condensate are collected intermittently. At the end of this period, the containment vessel is vented, and the plateout coupons and other sample devires are remnved. The toat cquipluenl and cell are then decontaminated in preparation for the following run.

1.32 Conduct of Tests. The principal operating conditions for Runs 3 and 4 are compared in Table XXVIII. Operation of the test equipment and facilities was generally satisfactory, and only minor problems were encountered in containing the fission products within the hot cell and in decontaminating the test equipment following each test. During Run 3, shortly after the melting stage of the run was concluded, the quartz furnace tube failed, blowing sintered fuel and bed material out of the quartz tube and into the cell. The containment vessel was immediately isolated. No contamination was released to the operating areas, and the run was continued on schedule. The confinement of activity to the cell and filtering system demonstrated the adequacy of the safety features of the facility. To prevent recurrence of the failure in future runs, a more rigid assembly for holding the furnace tube was designed to minimize mechanical stresses on the tube during and following assembly. The furnace tube was changed to prevent any spattering of molten fuel on the outer quartz wal1. The operation of the new furnace and assembly fixture was satisfactory for Run 4.

Numerous coupons were contaminated in Runs 3 and 4 for the LOFT coating selection and decontamination studies described in Section III-1.1. Containment atmosphere was drawn through four gas-particulate sampling cartridges and two of the LOFT gas-particulate capsule samplers diring both runs. The evaluation effor't on these samplers is being performed under the direction of the ICPP Analytical Branch and is reviewed in the ICPP Allalyllual Report [35], along with the development effort on analytical methods. Other results from the two runs are summarized in the following sections.

1.33 Fission Product Behavior. The percentages of various fission product nuclides that were released from the fuel pins during meltdown are given in Table XXIX for the first four CDE runs. The release values were obtained by dividing the quantity of each nuclide found in the containment vessel and transport line by the total amount of each nuclide present in the fucl pin, as determined by the RSAC curie code [36]. The release values do not include the fission products found in the quartz furnace; analysis of solutions used to leach the furnace tube indicate the fission product plateout on the tube is very low. The release percentages are in relatively good agreement though several meltdown parameters 
TABLE XXVIII

COMPARISON OF OPERATING CONDITIONS FOR CDE RUNS 3 AND 4

\begin{tabular}{|c|c|c|}
\hline Condition & Run 3 & Run 4 \\
\hline \multicolumn{3}{|l|}{ Fuel Element: } \\
\hline Diameter (inches) & $9 / 16$ & $9 / 16$ \\
\hline Length (inches) & $3-1 / 2$ & $3-1 / 2$ \\
\hline Cladding & Zircaloy-2 & Zircaloy-2 \\
\hline Meat & $\mathrm{UO}_{2}$ pellets & $\mathrm{UO}_{2}$ pellets \\
\hline Total uranium (grams) & 70.2 & 69.9 \\
\hline Enrichment (percent) & 8 & 8 \\
\hline Fuel element burnup (MWd/Tonne) & 740 & 440 \\
\hline Irradiation flux level $\left(\mathrm{n} / \mathrm{cm}^{2}-\mathrm{sec}\right)$ & $6.8 \times 10^{12}$ & $8.6 \times 10^{12}$ \\
\hline $\begin{array}{c}\text { Total activity in fuel element at reactor } \\
\text { shutdown (curies) }\end{array}$ & 7100 & 7800 \\
\hline $\begin{array}{l}\text { Iodine-131 activity in fuel element at } \\
\text { reactor shutdown (curies) }\end{array}$ & 41.5 & 39.9 \\
\hline $\begin{array}{l}\text { Cooling time until fuel element meltdown. } \\
\text { (hours) }\end{array}$ & 7 & 9.75 \\
\hline $\begin{array}{l}\text { Time after start of heating until initial } \\
\text { melting occurred (minutes) }\end{array}$ & 4 & 7 \\
\hline Time fuel pin was molten (minutes) & 20 & 25 \\
\hline Composition of transport gas over fuel & steam and $3 \%$ argon & steam and $3 \%$ argon \\
\hline $\begin{array}{l}\text { Velocity of transport gas over fuel } \\
\text { element }(\mathrm{ft} / \mathrm{sec})\end{array}$ & 1.85 & \\
\hline $\begin{array}{l}\text { Furnace and containment vessel pressure } \\
\text { during meltdown (psig) }\end{array}$ & 22 & 22 \\
\hline $\begin{array}{l}\text { Containment atmosphere temperature during } \\
\text { meltdown }\left({ }^{\circ} \mathrm{F}\right)\end{array}$ & 218 & 224 \\
\hline $\begin{array}{l}\text { Composition of containment atmosphere } \\
\text { during meltdown }\end{array}$ & $5 n \%$ air and $50 \%$ steam & $50 \%$ air and $50 \%$ steam \\
\hline Number of sampling systems installed: & & \\
\hline Raw gae sample bombs. & 2 & 2 \\
\hline Gas-jperticulate cartridges & 4 & 4 \\
\hline Gas-particulate capsules & 2 & 2 \\
\hline Plateout capsules & 2 & 2 \\
\hline Plateout coupons (ambient temperatiure) & 156 & 170 \\
\hline Plateout coupons (heated) & 16 & 0 \\
\hline Platout coupons (cooled) & 16 & 0 \\
\hline Continuous sampler-monitor & 1 & 1 \\
\hline Deposition tube (heated) & 1 & 1 \\
\hline Dejogition tube (ambient temperature) & 1 & 1 \\
\hline
\end{tabular}




\begin{tabular}{|c|c|c|c|c|}
\hline \multirow[b]{2}{*}{ Fission Product } & \multicolumn{4}{|c|}{ Percent Released } \\
\hline & CDE-1 & CDE-2 & $\mathrm{CDE}-3$ & $\mathrm{CDE}-4$ \\
\hline $\operatorname{Sr}-89$ & $<0.01$ & 0.05 & 0.02 & --- \\
\hline $\mathrm{Zr}-\mathrm{Nb}-95$ & Trace & Trace & 0.1 & 0.001 \\
\hline Mo-99 & 2.5 & 4.0 & 8.0 & 6.5 \\
\hline $\mathrm{Ru}-103$ & $<0.01$ & $0: 07$ & 0.7 & 0.2 \\
\hline$I-131$ & 15.0 & 17.0 & 17.0 & 23.0 \\
\hline Te-13:2 & 7.0 & 9.5 & 16.0 & 22.0 \\
\hline $\mathrm{Cs}-13 \mathrm{~T}$ & 11.0 & 13.0 & 27.0 & 8.0 \\
\hline$B a-140$ & --- & 0.04 & 0.01 & 0.16 \\
\hline Uranium & --- & --- & 0.26 & --- \\
\hline \multicolumn{5}{|c|}{$\begin{array}{l}\text { [a] Determined by dividing the fission products found in the contain- } \\
\text { ment vessel, reactor vessel, and furnace outlet line by the total amount } \\
\text { of each fission product present (RSAC Curie Code). Does not include } \\
\text { f'ission products found in the quarta furnacc. }\end{array}$} \\
\hline
\end{tabular}

were varied, eg, meltdown rate, transport gas veloolty, and burnup. There appears to be a trend toward a higher release with each succeeding run.

The fission product and fuel accountability data are shown in Table XXX for the first four CDE runs. The accountability, particularly of the nonvolatile fission products, shows a general improvement with each succeeding run, though the accountabilities of the volatile (greater than 15 percent release from fuel) fission products, I-131, Te-132, and Cs-137, were still low in Run 3. The low values can be attributed, at least in part, to losses following the furnace break. The accountabilities for the various nuclides are based on a fuel pin inventory calculated with the RSAC curie code.

The distribution of the various nuclides transported from the furnace in Run 3 is shown in Table XXXI. Comparable data for Runs 1 and 2 are not shown because data on the fission product activities in the containment atmosphere and transport line were not obtained. From the tabulation for Run 3, it appears that deposition in the transport line is small; the inaximum plateout found in the transport line was six percent (Cs-137). The ratios of the nuclide fractions plated out in the containment vessel (sum of activities in decontamination solutions and activities on samplers) with those found in the containment condensate vary from nuclide to nuclide as expected; however, the variations do not follow a pattern expected from knowledge of their general behavior. For 
FISSION PRODUCT AND MATERIAL ACCOUNTABILITY

\begin{tabular}{|c|c|c|c|c|}
\hline \multirow[b]{2}{*}{ Nuclide } & \multicolumn{4}{|c|}{ Percent Recovered } \\
\hline & $\underline{\mathrm{CDE}-1}$ & $\underline{\mathrm{CDE}-2}$ & $\mathrm{CDE}-3$ & $\mathrm{CDE}-4$ \\
\hline $\operatorname{sir}-89$ & 27 & 140 & 137 & 112 \\
\hline $\mathrm{Zr}-\mathrm{Nb}-95$ & 27 & 18 & 90 & 116 \\
\hline Mo-99 & 11 & $4^{[a]}$ & 66 & 101 \\
\hline$R u-103$ & 18 & 14 & 100 & 74 \\
\hline$I-131$ & 31 & 28 & 19 & 57 \\
\hline $\mathrm{Te}-132$ & 7 & .9 & 26 & $22^{[c]}$ \\
\hline Cs-137 & 84 & 23 & 27 & 93 \\
\hline $\mathrm{Ba}-140$ & 36 & 74 & 89 & 83 \\
\hline $\mathrm{Ce}-141$ & 55 & 10 & 91 & 47 \\
\hline Uranium (Fuel and Bed) & 98 & 101 & $85^{[b]}$ & 107 \\
\hline Zirconium (Cladding) & 103 & 98 & --- & --- \\
\hline $\begin{array}{l}\text { [a] Fuel residue solut } \\
\text { [b] Based on the U-235 } \\
\text { [r] Not reported in the }\end{array}$ & $\begin{array}{l}\text { nalyzed } \\
\text { vered } \\
\text { l resic }\end{array}$ & $\begin{array}{l}\text { late to } \\
\text { che fuel } \\
\text { ample. }\end{array}$ & $\begin{array}{l}\text { in relia) } \\
\text { residue. }\end{array}$ & ata. \\
\hline
\end{tabular}

'I'ABLE' XXXI

DISTRIBU'I'ION OF FISSION PRODUCTS TRANSFORTED FROM THE FURNACE -- CDE RUN 3

\begin{tabular}{|c|c|c|c|c|c|c|c|c|}
\hline & \multicolumn{8}{|c|}{ Percentage of Total of Each Nuclide } \\
\hline & $\underline{S r-89}$ & $\mathrm{Zr} / \mathrm{Nb}-95$ & Mo-99 & $\underline{\mathrm{Ru}-103}$ & $I-131$ & $\underline{T e-132}$ & $\underline{\mathrm{Cs}-137}$ & $\mathrm{Ba}-140$ \\
\hline Containment Conaensate & 6.80 & 97.17 & 51.71 & 9.40 & 54.31 & 29.05 & 60.42 & 1.03 \\
\hline $\begin{array}{l}\text { Containment Decontamination } \\
\text { Solutions }\end{array}$ & 92.49 & 2.78 & 42.83 & 84.10 & 37.03 & 64.24 & 30.07 & 91.37 \\
\hline Deposition Samples & 0.12 & 0.05 & 0.60 & 0.46 & 3.93 & 0.53 & 0.29 & 0.58 \\
\hline Containment Atmosphere & [a] & [b] & 3.37 & 4.90 & 3.65 & 3.81 & 3.06 & 2.24 \\
\hline Transport Line & 0.59 & [b] & 1.49 & 1.14 & 1.02 & 2.37 & 6.16 & 1.78 \\
\hline \multicolumn{9}{|c|}{$\begin{array}{l}\text { [a] Analysis not obtained. } \\
\text { [b] Activtty too low to be aerectia. }\end{array}$} \\
\hline
\end{tabular}


example, $\mathrm{Sr}-89$ and. Ba-140 should appear higher in the condensate than they do because of their solubilities. Conversely, the insoluble $\mathrm{Zr}-\mathrm{Nb}-95$ should plate out to a greater extent. Presence of the fission products on undissolved solids in the liquid samples and nonrepresentative samples are suspected as the reasons for the unusual behavior indicated by the analyses.

1.34 Particulate Concentration and Composition. Three unirradiated fuel pins were melted during cold tests made prior to CDE Run 4. During one of the cold tests, a sample of the containment atmosphere was drawn through a Millipore Type AA filter and analyzed by X-ray fluorescence and emission spectrometry to determine the composition of the particulates. A sample of the particulates plated out on the outlet end of the quartz furnace was also obtained. The results, shown in Table XXXII, indicate that the tin in the Zircaloy cladding is preferentially volatilized. Both silicon (from the quartz furnace) and zirconium show little volatilization. Additional tests of this type are planned.

TABLE XXXII

COMPOSITION OF FARTICULATES RELHASED FROM CDE FUEL

\begin{tabular}{lcc}
\hline Component & $\begin{array}{c}\text { Containment Concentration } \\
\mu \mathrm{fgt3}\end{array}$ & $\begin{array}{c}\text { Plateout Sample } \\
\text { Hg }\end{array}$ \\
\cline { 2 - 3 } Tin & 690 & 800 \\
Uranium & 570 & 175 \\
Silicon & 11 & 20 \\
Zirconium & $<1$ & $<1$ \\
\hline
\end{tabular}

1.35 Rare Gas Content of Fuel. The fuel pin that was melted during CDE Run 4 was dissolved in an apparatus that quantitatively trapped the krypton and xenon. The dissolution was conducted in such a manner that the gases from dissilution of the UO, cure were collected separately from those from dissolution of the Ziroaloy eladulug.

'I'he quantities of the two gases found in the $\mathrm{UO}_{2}$ were 0.02 standard cc of krypton and 0.14 standard cc of xenon. The amounts of gas in the cladding were less than the detectable limit of 0.001 standard cc. This indicates that the gases were bound in the $\mathrm{UO}_{2}$ lattice.

1.36 Decontamination of Facility. The CDE equipment and cells require decontamination following each run. Though dernnta mination is donc primarily to permit repeated tests, it also affords an opportunity to obtain practical experience on the relutive effectiveness of decontaminants and to test equipment and decontamination procedures on a large scale. The decontamination equipment installed in the $\mathrm{CDE}$ include;

(1) Sprays in the containment vesse1

(2) Flushing connections to critical lines and equipment

(3) Cell sprays 
(4) Three 100-gallon mixing tanks in which the decontaminating solutions are prepared

(5) Waste storage tanks in which the waste solutions are collected

(6) A system for sampling the decontamination solutions.

From the experience gained from the four runs, in which the order of application of the various decontaminating solutions has beenvaried and the procedures have been changed, the following method of decontamination has evolved:

(1) Remove all samples

(2) Remove the fuel residue and other "hot" items that can be removed remotely

(3) Spray the containment vessel through the in-vessel sprays and flush the condensate system lines and the transport line

(4) Wash the cell interior with cell sprays

(5) Enter the cell and remove remaining "hot" items manually

(6) Enter the cell and wàsh walls and equipment using a portable decontamination unit (pump, tank, hose, and spray nozzle)

(7) Enter the cell and complete cleanup by mopping, brushing, etc.

The procedure has proved to be quite effective. Following a normal test run, this procedure reduces the general radiation levels in the cell from $\approx 100 \mathrm{R} / \mathrm{hr}$ to less than $1 \mathrm{mR} / \mathrm{hr}$ and can be completed in about one week. The solutions (which include water washes and several commercial products) and the order of application are being varied to evaluate their relative effectiveness on each of the fission product isotopes. More test data are needed to complete this comparison; however, it appears that the soluble stiuntium and cesinm isotopes are removed preferentially by the water washes.

The furnace failure in Run 3 caused many particulates to be blown into the cell. Many of these particulates had lo le locatod with hand-ciarried radiation instruments and then be picked up with sticky paper.

1.4 Continuous Sampler-Monitor for the Containment Building Atmosphere (R. E. Schindler; Development Engineering Section)

A Continuous Sampler-Monitor (CSM) is being developed for use in sampling the contalnment building atmosphere to determine the fission product concentrations during the Loss-of-Fluid Test. The CSM, for which a schematic flow sheet is shown in Figure 33, would use a scrubber located in the containment building to sample the atmosphere continuously and to separate the fission products Into two streams which flow separately through the containment wall to radiation monitors and samplers located outside the building. The scrubber, located in the containment atmosphere to avoid problems with fission product plateout on long sampling lines, washes nearly all of the condensible fission products out of the atmosphere sample into a liquid stream, leaving essentially only rare gas fission products in the gas stream. The scrubbing of the atmosphere 


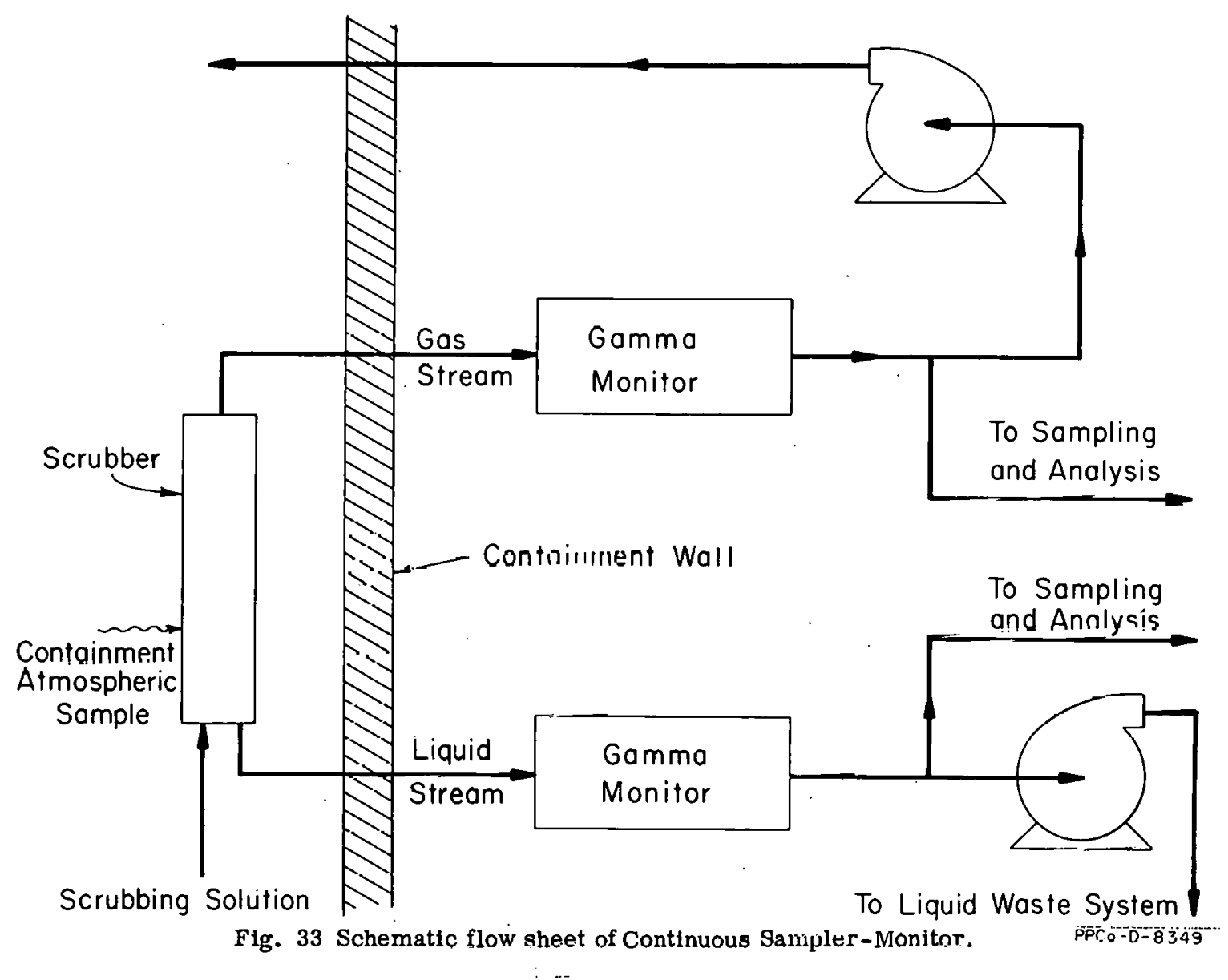

sample allows the condensible and ingestible fission products (primarily iodine) to be monitored apart from the more active but less hazardous (less ingestible) rare gases. The radiation monitors and samplling slalions are located outside the containment building, where the backgruund rudtation is moderate and the equipment is accessible. Gross gamma monitors on each sampling line will provide a continuous record of the gross condensible and rare gas fission product activities in the containment atmosphere. Samples taken from each stream will be analyzed for the major isotopes using spectrum stripping techniques which are being developed by the Nuclear Physics Section. The Continuous Sampler-Monitor will provide useful data on the time and rate of events during the meltdown,eg, the time fission products first reach the containment atmosphere, the rates of increase (or decrease) of fission product concentration, and peak fission product concentrations.

A spray scrubber, such as the one shown in Figure 34, offers a simple and potentially effective means of scrubbing condensible fission products from the containment atmosphere sample. The sample enters through a port in the side of the scrubber, then passes upward through the spray and a de-entrainment device. Iodine, the fisston product of greatest concern, can be released in at least four forms: elemental fodine vapor, hydrogen lodide, organic iodides, and lodine adsorbed on particulate matter. Owing to their known ability to react rapidly with the inorganic lodine vapors (elemental lodine and hydrogen lodide), caustic scrubbing solutions have been used in the CSM scrubber. The ability of 
a spray scrubber to scrub elemental iodine vapor with a caustic solution was demonstrated in previously reported [1] tests. Currently reported activities include laboratory evaluations of the scrubber performance on fine particles and organic iodides, testing of the CSM in the Contamination-Decontamination Experiment, evaluation of materials for the scrubber, and development of techniques for analyzing samples taken with the CSM.

1.41 Evaluation of the CSM Spray Scrubber for Particulates Scrubbing. Since a portion of the fission product activity in the LOFT containment atmosphere is expected to be in the particulate form, the effectiveness of the Continuous Sampler-Monitor (CSM) in scrubbing particulates from an atmosphere sample was studied. A fluorescein dust with a size range of $0.05-$ to 0.7 micron diameter was used to test the performance of the CSM spray scrubber on particles under a number of conditions. From these, it was found that the scrubber will effectively scrub the particles larger than 0.2-micron diameter, but most of the finer particles pass on through. Thus, the performance of the CSM spray scrubber on particulate fission products will depend strongly on the size distribution of the particulates released.

(1) Experimental Apparatus. The experimental equipment used to evaluate the CSM spray scrubber is shown schematically in Figure 35. A fluorescein dust with a mass median diameter of 0.43 micron was produced by atomizing a fluorescein solution with a pneumatic atomizing nozzle and allowing the resulting spray to dry. The air and liquid flows to the atomizing nozzle were metcred to obtain reproducible size distributions of the dust. The particle size distribution shown in Figure 36 was obtained from electron microscope photographs of two samples of the fluorescein dust. The particles ranged in size from 0.05 to 0.7 micron in diameter.

The spray scrubber (Figure 35) consisted of a piece of "Pyrex" pipe with a spray nozzle placed in one end. To evaluate the effect of various design parameters on the scrubber performance, tests were made using four swirl 


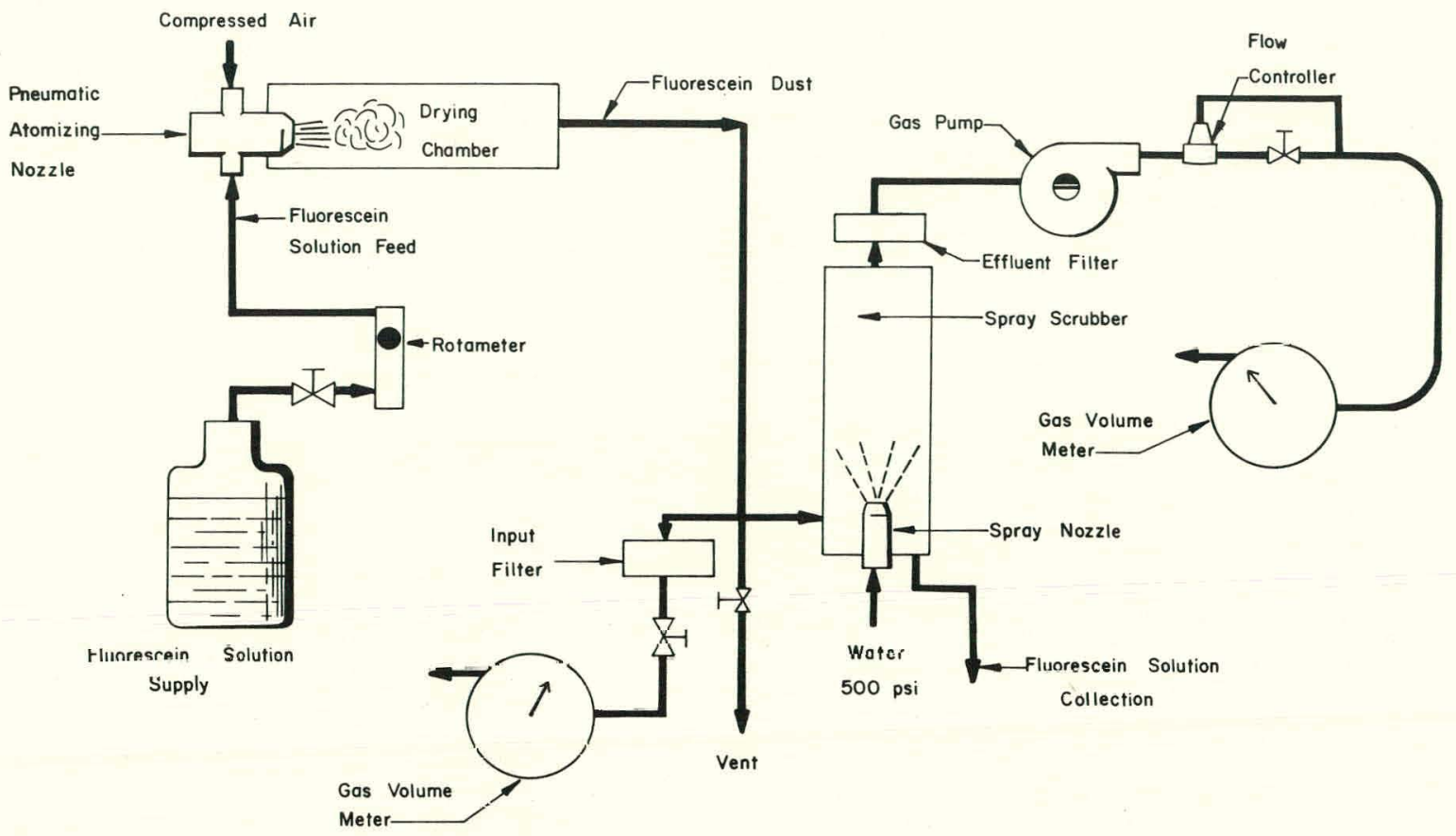

Fig. 35 Schematic flow sheet of apparatus for fluorescein dust scrubbing test.

pressure-atomizing nozzles (Delavan nozzles sizes were $0.50 \mathrm{gph}-90^{\circ}, 0.75 \mathrm{gph}-$ $70^{\circ}$, and $1.00 \mathrm{gph}-70^{\circ}$, and a Spraying Systems nozzle size was $0.60-1 / 4$ LNN) placed either spraying upward in the bottom of the scrubber or down from the top of the scrubber. The scrubbing chambers were 12- or 18-inch sections of 1-1/2- or 2-inch-diameter "Pyrex" pipe. Water supplied at a pressure of 500 psi was used as the scrubbing liquid for all the tests.

The air containing dust. was passed upward through the scrubber at several flow rates. The scrubber perfnrmance wad measuied by collecting samples, with glass fiber filters. of the fluoresocin dust in the alr entering and leaving the scrubber as shown in Figure 35. The volume of air passing through each filter was measured with a wet-test gas volume meter. A colorimetric method of analysis was used to measure the quantity of fluorescein on each filter. To obtain a material balance on the scrubber, samples of the fluorescein solution leaving the scrubber were taken; however, most of them proved to be too dilute for an accurate analysis.

(2) Results. The spray scrubber removed 98 to 99 percent of the fluorescein dust fed into it in all but a few of the tests. The experimental scrubbing efficiencies varied from a low of 95.3 percent to a high of 99.53 percent; however, the majority was between 98 and 99 percent.

Random errors (on the order of two percent) in the experimental data mask the effect of the operating parameters on scrubbing efficiency. The effects of chamber diameter, chamber length, and spridy direction are too small (less than one percent) to be observed. A small decrease -- about half a percent -- in scrubbing efficiency can be observed when the air flow is increased from 200 $\mathrm{ml} / \mathrm{min}$ to $600 \mathrm{ml} / \mathrm{min}$. Slight differences in performance could also be observed with different spray nozzles. 


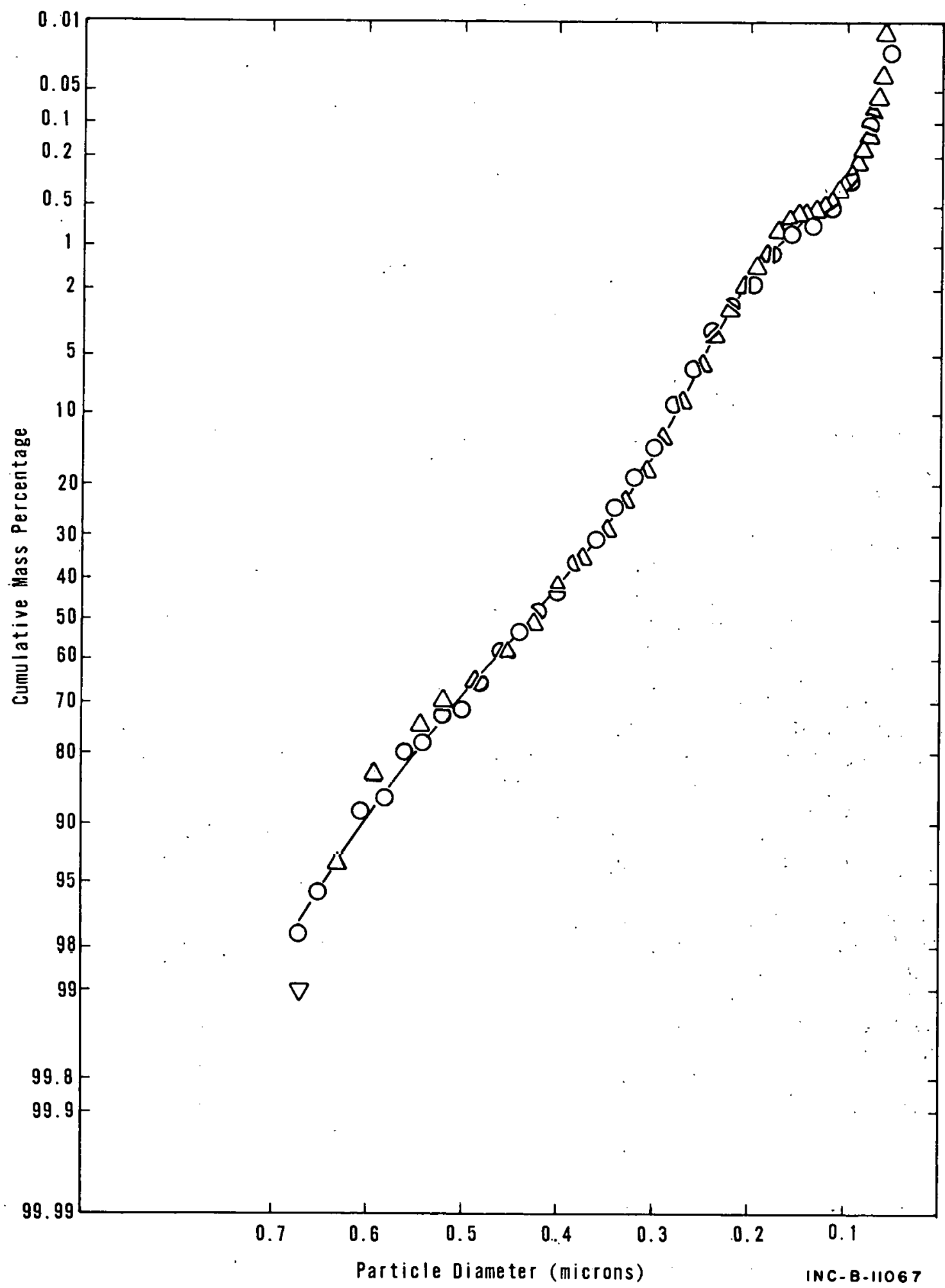

Fig. 36 Particle size distribution of fluorescein dust. 
(3) Discussion. The most noticeable feature of the results is that none of the experimental parameters had a strong effect on scrubbing efficiency. The published literature on the impaction of particles on spray drops offers an explanation [37]. The impaction efficiency of spheres, ie, the ratio of the effective cross section to the actual cross section, is a function of $\sqrt{\psi}$, where

$$
\begin{aligned}
& \sqrt{\Psi}=D_{p} \sqrt{C \rho_{p} V / 18 \mu D_{c}} \\
& D_{p}=\text { diameter of the particle } \\
& C=\text { Cunningham slip correction } \\
& \rho_{p}=\text { density of the particle } \\
& V \quad=\text { relative velocity between particle and collector } \\
& \mu \quad=\text { viscosity of the gas } \\
& D_{c}=\text { diameter of the collector. }
\end{aligned}
$$

The impaction efficiency, $n$, which is shown in Figure 37 as a function of $\sqrt{\Psi}$, rises sharply as $\sqrt{\Psi}$ goes from 0.15 to 1 . Outside of this narrow range, changes in $\sqrt{\Psi}$ have little effect.

Equation (1) shows that scrubbing by the impaction mechanism is optimized by using a spray with the highest possible drop velocity and the lowest possible drop size. This is achieved for swirl pressure atomizing nozzles by operating small spray nozzles at high pressure [38]. The spray scrubbing tests were conducted operating the smallest available nozzles at a pressure of $500 \mathrm{psi}$. Delavan nozzles of the type used are reported to produce sprays with a mass median diameter of about 70 microns at 100 psi pressure; higher atomizing pressures produce finer sprays[38].

Some impaction efficiencies, taken from the curve of Ranz and Wong [37], for the conditions [a] of the spray scrub. bing tests are tabulated in Table XXXIII for various drop and particle sizes. The impaction efficiencies in Table XXXIII are low for particles smaller than 0.2 micron but appreciable for larger particlcs.

The particle size distribution shown in Figure 36 reveals that 98 percent of the fluorescein is contained by the particles larger than 0.2 -micron diameter. This fraction, 98 percent, agrees with the measured scrubbing efficiencies. It

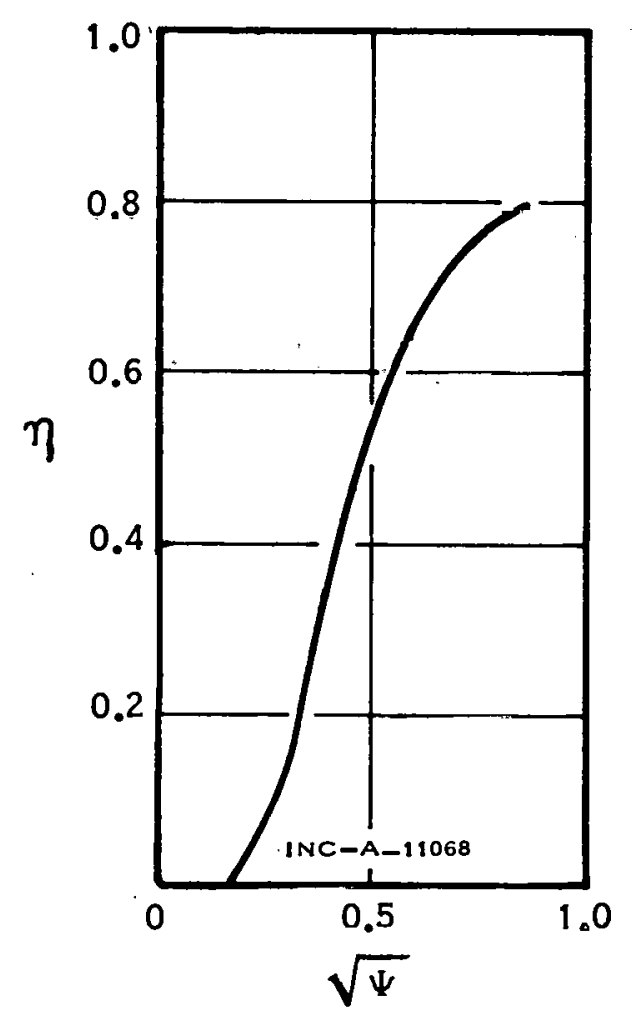

Fig. 37 Impaction efficiencies of spherical collectors.

$\begin{aligned} \text { [a] } v= & 190 \mathrm{ft} / \mathrm{sec}(70 \text { percent of the velocity from a frictionless nozzle } \\ & \text { at } 500 \mathrm{psi}), \rho \mathrm{p}=0.8 \mathrm{~g} / \mathrm{ml}, \mathrm{c}=1 .\end{aligned}$ 
TABLE XXXIII

IMPACTION EFFICIENCIES OF SPRAY DROPS

\begin{tabular}{cccccccc}
\hline Particle Diameter, Micron & $\frac{0.6}{0.8}$ & $\frac{0.4}{0.6}$ & $\frac{0.3}{0.4}$ & $\frac{0.2}{0.15}$ & $\frac{0.15}{0.02}$ & $\frac{0.1}{0.0}$ \\
70 micron drop & 0.8 micron drop & 0.83 & 0.73 & 0.55 & 0.22 & 0.05 & 0.0
\end{tabular}

thus appears that the cut-off of impaction efficiency with decreasing particle size is the effect which controls the measured scrubbing efficiencies. Under the conditions of the experiments, the scrubber removes all the dust larger than 0.25 micron, a varying fraction of the dust between $0.15-$ and 0.25 -micron dlameter, and very little of the dust smaller than 0.15-micron diameter. In more general terms, the cut-off conditions of the spray scrubber are an impaction efficiency of 0.2 or a value of $\sqrt{\Psi}$, as defined in Equation (1), of $1 / 3$.

Equation (1) also shows that dense particles are relatively easier to scrub. For example, if the spray scrubber will remove fluorescein particles down to $0.2-$ micron diameter, it will scrub particles down to 0.075-micron diameter for $\mathrm{ZrO}_{2}\left(\rho_{\mathrm{p}}=5.6\right), 0.07$-micron diamter for $\mathrm{SnO}_{2}\left(\rho_{\mathrm{p}}=7.0\right)$, and $0.055-\mathrm{micron}$ diameter for $\mathrm{UO}_{2}\left(\rho_{\mathrm{p}}=11.0\right)$.

The particulates released by molten $\mathrm{UO}_{2}$ are usually extremely fine. Particle sizes reported [39] by ORNL range down to less than 0.01 micron. Particles of this size will probably pass through the CSM scrubber; however, condensation of steam on the fine particles can enhance scrubbing by producing drops large enough to be scrubbed. For example, saturated steam at $230^{\circ} \mathrm{F}$ contains enough water to form 5 micron drops if condensed uniformly on a particle cloud containing $10^{7}$ particles $/ \mathrm{cm}^{3}$ (an estimate for LOFT based on the agglomeration data of Gussman [40]). The effectlveness of the CSM spray scrubber for removing fine particles will, thus, depend strongly on whether steam condenses on the particles. Unless moisture condenses on them to form larger particles, the fine particles and the fission products adsorbed on them will probably pass through the scrubber.

(4) Conclusions -- Spray Scrubbing of Particles.

(1) A spray scrubber can effectively scrub fluorescein dust particles larger than $0.2-$ micron diameter when scrubbing low afr throughput at a spray pressure of $500 \mathrm{psi}$.

(2) The sorubbing of particles larger than 0.2 micron is unaffected by a number of design and operating parameters (in the ranges studied): scrubbing chamber size, spray direction, air throughput; and nozzle size and make.

(3) Particle sizes reported by ORNL for fission product releases from molten fuels are mostly in size ranges smaller than the particles which the spray scrubber has been observed to collect. Unless steam condenses on these fine particles, a major share w1ll probably penetrate the sorubber. 
1.42 Evaluation of the CSM Spray Scrubber for Adsorption of Methyl Iodide Vapor. Laboratory tests indicate that the scrubbing efficiency of the CSM spray scrubber for methyl iodide "is considerably lower than that observed for molecular lodine. An average scrubbing efficiency of about one-third was observed when scrubbing methyl iodide with a caustic thiosulphate mixture at temperatures from 37 to $75^{\circ} \mathrm{C}$ with gas flow rates of around $200 \mathrm{cc} / \mathrm{minute}$.

A series of screening tests performed by Hammer[1] using a bubbler-type scrubber revealed a number of solutions which react with methyl iodide. These included oxidizing acid mixtures, mercury salts, and some reducing agents. The caustic thiosulphate mixture was chosen from these solutions because it is a basic solution which reduces fodine to a soluble form.

(1) Experimental Method. The scrubbing tests were conducted by passing tracer methyl iodide through a scrubber which was set up in a constant temperature bath as shown in Figure 38. The scrubbing efficiensy was determined by measuring the quantity of methyl iodide in the sorubbing solution and in the gas which passed through the scrubber. An independent check on the scrubbing efficiency was obtained by measuring the average conoontration of rictictil lodide in a small side stream of the carrier gas entering the scrubber. Both gas and liquid streams passed through warming colls in the temperature bath to allow them to reach the desired temperature before reaching the scrubber. The scrubber body consisted of a one-foot section of $1-1 / 2$-inch-diameter Pyrex pipe, and the spray nozzle was a $0.50 \mathrm{gph}-90^{\circ}$ nozzle operated at $400 \mathrm{psi}$ pressure. The flow of scrubbing solution from the nozzle was about $45 \mathrm{cc} /$ minute. Gas throughput rates varied from $170 \mathrm{cc} /$ minute to $650 \mathrm{cc} / \mathrm{minute}$; however, most of the flow rates were around $200 \mathrm{cc} /$ minute. Three different scrubbing solutions were used: a $0.5 \mathrm{M} \mathrm{NaOH}-0.5 \mathrm{M} \mathrm{Na}_{2} \mathrm{~S}_{2} \mathrm{O}_{3}$ mixture, a $0.5 \mathrm{M} \mathrm{NaOH}$ $-1.0 \mathrm{M} \mathrm{Na} \mathrm{S}_{2} \mathrm{O}_{3}$ mixlure, and water.

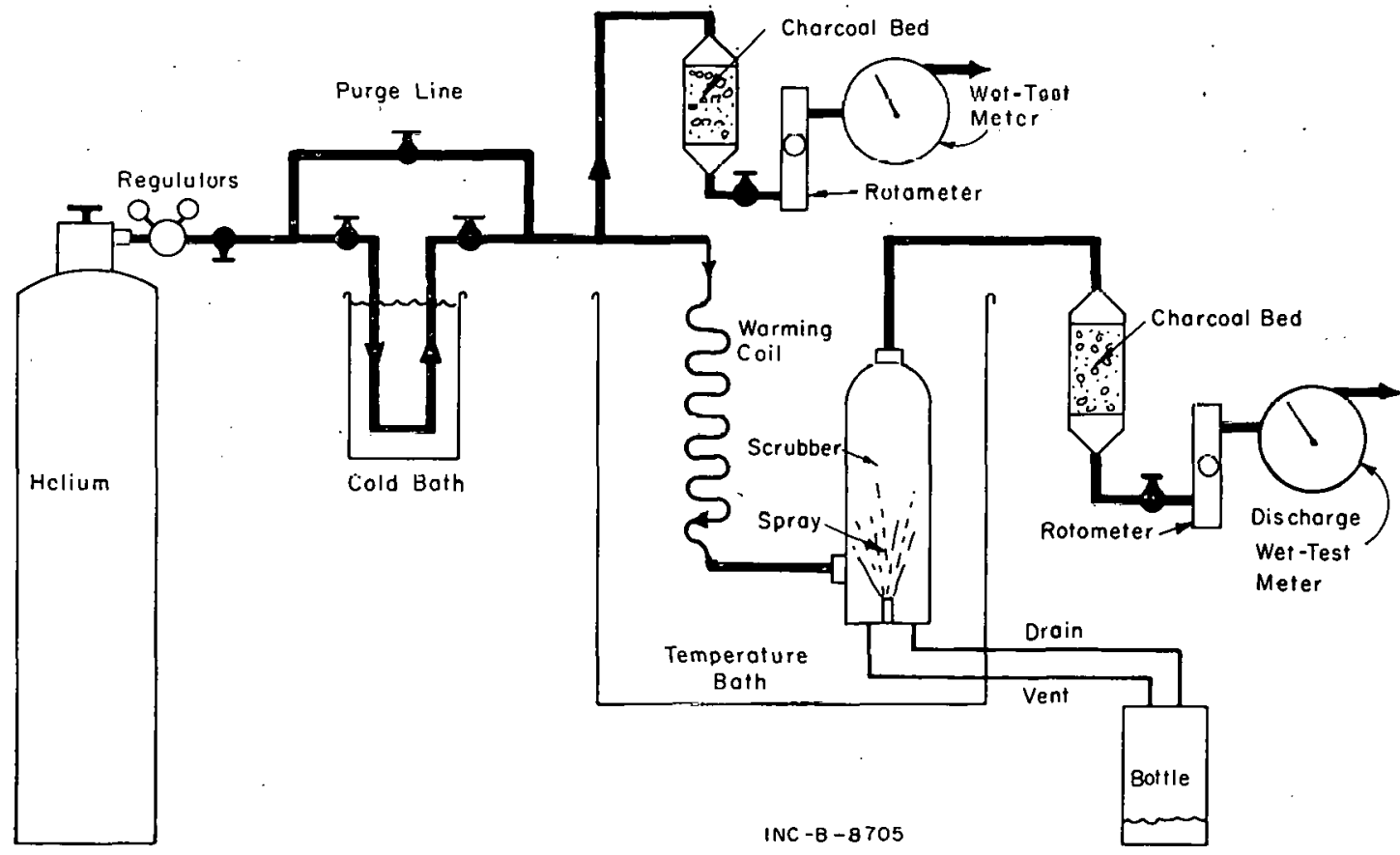

Fig. 38 Schematic flow sheet of apparatus for the methyl lodide scrubbing test. 
The scrubbing tests were carried out by vaporizing tracer level methyl iodide $\left(\mathrm{CH}_{3} \mathrm{I}^{131}\right)$, into the helium carrier gas flowing into the scrubber. A small bed of charcoal impregnated with triethylenediamine was used to collect the methyl iodide not removed by the scrubber. During the first run, the charcoal bed was backed up by a liquid nitrogen cold trap to determine the penetration of methyl iodide through the charcoal; no penetration, however, was detected. The scrubbing solution was allowed to drain from the scrubber into a collection bottle which was vented to the scrubber.

(2) Results. The measured scrubbing efficiencies varied from 18 to 63 percent and averaged 35 percent; interpretation of the data was complicated by data point scatter. The discrepancies in the material balance on the methyl iodide entering and leaving the scrubber averaged 30 percent.

The strongest observable effect was the decrease in scrubbing efficiency with increasing gas flow rate. In a series of consecutive runs under the same conditions (other than gas flow rate), the scrubbing efficiency dropped from 35 percent at a gas flow of $185 \mathrm{cc} /$ minute to 7 percent at a gas flow of $650 \mathrm{cc} / \mathrm{minute}$. No significant effect of temperature could be observed over the range from 37 to $75^{\circ} \mathrm{C}$. No significant difference could be observed between the $0.5 \mathrm{M}$ and $1.0 \mathrm{M}$ $\mathrm{Na}_{2} \mathrm{~S}_{2} \mathrm{O}_{3}$ solutions; however both thiosulphate solutions scrubbed appreciably better than water.

(3) Discussion. The probable reason for the difference between the performance of the spray scrubber and the bubbler scrubber used by Hammer [1] is the difference in contact time between gas and liquid. The spray drops travel to the wall of the spray scrubber in a millisecond while a bubble takes about a second to pass through a bubbler scrubber. Only a reagent which reacts very rapidly can remove methyl fodide insuch a short contact time. Much of the scrubbing probably takes place in the fine drifting mist formed in the center of the spray cone (this mist comprises about one percent of the spray liquid) and in the liquid on the sides of the scrubber.

1.43 Performance of the Continuous Sampler-Monitor During CDE Run 3. The results of testing the Continuous Sampler-Monitor scrubber during CDE Run 3 confirm previously determined performance characteristics. The scrubber performs well on inorganic lodine vapors and large particulates, but poorly on fine particulates (presumably less than 0.1 micron) and organic lodides. The scrubber performance was evaluated by measuring the lodine content of the gas stream leaving the scrubber at three times during the CDE run. In the period shortly after the meltdown, about one-half of the airborne lodine penetrated the scrubber, apparently adsorbed on a fine particulate which was composed of Zircaloy cladding fumes. During the middle of the run, the scrubber removed the iodine from the gas stream almost completely. Near the end of the run, lodine penetration rose again, presumably because of an increase in the organic lodide fraction of the gas sample.

(1) Experimental Setup. The CSM was installed, as shown schematically in Figure 39, to allow sampling of the gas and liquid effluent streams flowing from the scrubber. A sample of the condensible (iodine) and particulate fission products in the gas stream was taken by diverting the gas stream for a measured time interval through a sampler consisting of a glass fiber filter and a bed of charcoal (impregnated with triethylenediamine) in series. The scrubbing liquid 


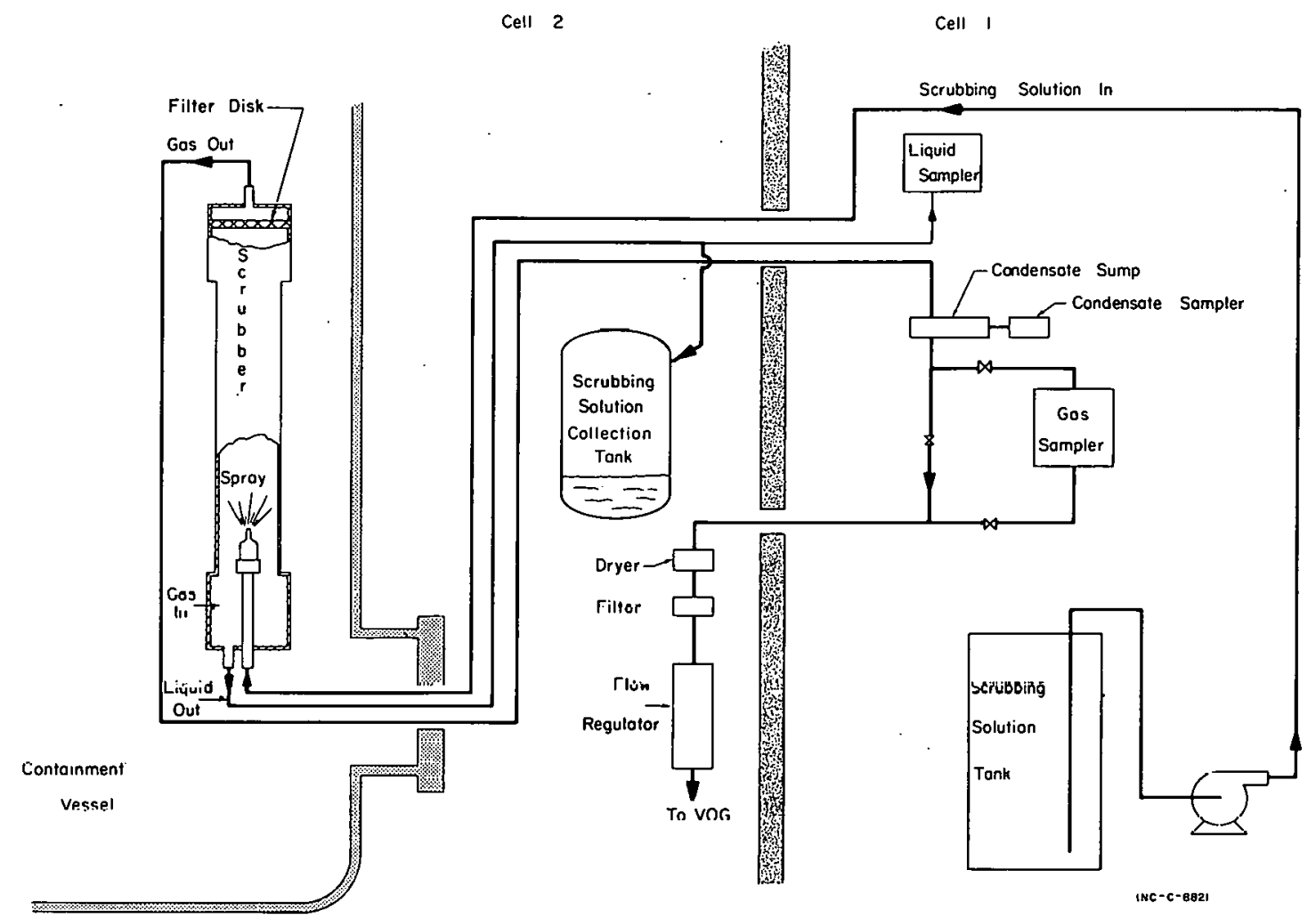

Fig. 39 CSM schematic flow sheet for CDE Run 3.

samples were drawn from the liquid effluent line before the liquid reached the collection tank. Moisture collecting in the gas line was collected in a sump and sampled.

The CSM scrubber which was placed inside the containment vessel consisted of a vertical 'l'etlon cylinder containing a spray nozzle in the bottom and a porous Teflon filter, used as a de-entrainment device, at the top. The atmosphere sample enters through a port in the side of the scrubber and passes up through a spray of scrubbing liquid composed of a $0.5 \mathrm{M}$ sodium hydroxide $-0.5 \mathrm{M}$ sodium thlosulphate mixture. The scrubbing liquid reaches the scrubber through a line of sufficient length to allow the liquid to warm to the containment temperature before being sprayed into the scrubber. Thus, there was little or no condensation in the scrubber.

The CSM scrubber was operated for about 30 minutes during each of the three sampling periods and shut off between sampling periods. The first sample was taken about one hour after the start of the meltdown ( $1 / 2$ hour after isolation); the second and third samples were taken 5 and 25 hours, respectively, after meltdown:

(2) Scrubber Performance. The data on the CSM performance provided by the laboratory studies were used in interpreting the results of the CDE Run 3 tests. Based on these studies; the CSM scrubber was expected to perform well on inorganic iodine ( $\mathrm{HI}$ and $\mathrm{I}_{2}$ ) and large particles, but not on organic iodides and very fine particles. The actual results confirm these observations. 
(3) Iodine Distribution. A relative distribution of I-131 for each of the three sampling periods was calculated from the quantities of I-131 found in the scrubbing solution samples, the gas line filters, and the gas line charcoal beds. The percentages listed in Table XXXIV were calculated by converting the quantity of I-131 in each sample to a common basis (a unit volume of gas sample) and then dividing by the total of the three samples. The scrubber was operated in the same manner during each sampling period; hence, the observed differences in scrubber performance can be attributed to differences in the nature of the CDE atmosphere at the time of sampling.

TABLE XXXIV

RELATIVE DISTRIBUTION OF IODINE-131 IN THE SCRUBBER-FILTER SYSTEM

(Percentage)

\begin{tabular}{lccc}
\hline Hours After Meltdown & $\frac{1}{46}$ & $\frac{5}{99.7}$ & $\frac{25}{87}$ \\
Scrubber solution & 11 & 0.01 & 0.02 \\
Gas line filter & 43 & 0.3 & 13 \\
Charcoal bed & $\cdots$ & 0.3 & \\
\hline
\end{tabular}

During the first sampling period, about half of the fission product iodine penetrated through the scrubber and was collected by the particulate filter and charcoal trap. Since the scrubber removes the inorganic lodine, most of the lodine found in the filter and charcoal at the end of the first hour after meltdown must have penetrated the scrubber either adsorbed on fine particles or as organic iodides. Iodine which is carried through the spray reversibly adsorbed on fine particles might then desorb and migrate through the filter to the charcoal bed. The one-day delay between the time the sample was taken and the time the sample was packaged allowed ample time for loosely adsorbed iodine to migrate acrnss the $1 / 8$-inch gap from the filter to the charcoal. A comparison with the quantity of iodine on the charcoal in the other two samples suggests that much of the iodine in the first sample charcoal arrived by this mechanism rather than as an organic lodine.

During the second sampling period five hours after meltdown, the CSM scrubber performed very well by scrubbing out 99.7 percent of the collected lodine. The airborne lodine must have been almost entirely inorganic fodine for the scrubber to have worked so well. Apparently, the copious particulate observed during the earlier sampling period had either been washed out by the condensing stream or coagulated to a scrubbable size. The 0.3 percent of the iodine found In the charcoal could have come from either inorganic lodine which passed through the scrubber, organic lodides, or desorption of lodine which had plated out in the gas sampling line during the previous sampling period. The good performance of the scrubber during this sampling period shows that it was functioning properly and that it can effectively scrub a favorably composed atmosphere sample.

During the last sampling period, which was 25 hours after meltdown, iodine again penetrated the scrubber in quantity, appearing in the charcoal bed but not on the filter. This "penetrating" lodine is probably composed of organic iodides 
which formed late in the run and constitutes a very small fraction of total lodine released from the fuel.

(4) Total Airborne Iodine. The total amount of lodine-131 airborne in the containment atmosphere (calculated from the total of that found in the scrubbing solution and the gas stream) is listed in Table XXXV for each of the three sampling periods as a percentage of the fuel pin inventory (33 curies of lodine131). Maypack samples taken at about the same time as the one-hour and 25-hour samples contained more lodine than the corresponding CSM samples. The onehour CSM sample agreed within 25 percent with those from the Maypack samplers, but the CSM sample taken after 25 hours contained only one-third as much fodtne as the corresponding Maypack samplers [35].

TABLE XXXV.

PERCENT OF IODINE-.1 37 TNVENTORY AIRBORNE IN CONTAINMINT

\begin{tabular}{|c|c|c|c|}
\hline Hours After Meltdown & 1 & 5 & 25 \\
\hline Pereent Airuorre Iodine & 3.75 & 0.70 & 0.26 \\
\hline
\end{tabular}

(5) Nature of the Particulate. The particulate matter which was collected on the filter during the first sampling period was analyzed by emission spectroscopy. A trace of tin (a minor component of the Zircaloy cladding) was detected, but no uranium was found even though the Maypack filters collected large quantities of uranium. Apparently most of the uranfum particles were scrubbed out while tin particles passed through the scrubber.

(6) Fissiun Product Plâteout. 'The extent of plateout of activity on surfaces of the sampling system was determined by removing sections of tubing and other surfaces after the CDE min and measuring the fisoion products on them. The quantity of I-131 lost in the sampling lines upstream of tho oarripling juiluts was calculated from the analysis of the tubing samploo. The overall iudlut balance tabulated in Table XXXVI was prepared by estimating the total quantity of iodine passing the sampling points during the three sampling periods, adding the plateout to obtain a total sample, then calculating the relative lodine distribution.

The plateout of lodine appears to represent a significant loss of iodine only in the case of the gas line. About ten percent of the total lodine penetrated the scrubber (probably during the first sampling period) and plated out in the gas sampling line before reaching the gas sampler. The iodine plateout in the liquid sampling line represents only a small fraction of the total lodine sample; however, its bulldup over the run may still require intermittent decontamination for an on-line gross

$\underline{T \wedge B L E X X X X I}$

RELATIVE DISTRIBUTION OF IODINE131. THROUGHOUT SYSTEM, INCLUDING LINE PLATEOUT

(Percentage)

\begin{tabular}{lc}
\hline Scrubbing Solution & 48 \\
Gas Stredm & 41 \\
Gas Iine Plateout & 10 \\
Liquid Line Plateout & 0.15 \\
Condensate in Gas Line & 0.15 \\
Teflon Mist Collector & 1.3 \\
\hline
\end{tabular}


gamma monitor. The lodine lost by plateout could represent about a ten percent error in the numbers presented in Tables XXXIV and XXXV -- primarily in those for the first sampling period. An error of this magnitude will not affect any conclusions reached about the scrubber performance.

(7) Other Fission Products. The CSM samples were not analyzed until many of the fission products had decayed away; however, a complete set of data was obtained for $\mathrm{Te}-129, \mathrm{Cs}-137$, and $\mathrm{Ru}-103$, as well as I-131. The distribution of these fission products was about the same as for iodine-131, except for Ru-103 which penetrated the spray and plated out in the sampling lines to a much greater extent than any other fission product.

(8) Conclusions. The following conclusions can tentatively be drawn from the CSM data for CDE Run 3:

(1) The CSM scrubber, as currently designed, will remove inorganic iodine vapors and large particles but will not be efficient for scrubbing fine particulates or organic iodides.

(2) Shortly after meltdown in CDE, half the airborne iodine in the containment atmosphere was in a form which penetrated the scrubber -- probably adsorbed on fine particulates but possibly also as organic iodides.

(3) The fine particulate which penetrated the scrubber consisted of tin fumes from the Zircaloy cladding -- presumably with a diameter of less than 0.2 micron.

(4) The fine particulate had washed out of the atmosphere or coagulated within five hours after meltdown.

(5) Twenty-five hours after meltdown, a significant fraction (greater than 13 percent) of the residual airborne lodine was organic, but this consitutes less than one percent of the iodine released from the fuel.

1.5 Fission Product Sorption on Materials of Construction for the CSM (M. R. Fox; Chemistry Section)

In an attempt to find a material of construction for the Continuous Sampler Monitor (Section III-1.4) with low fission product retention, 18 coupons of uniform dimensions of six different materials were contaminated in the Contamination-Decontamination Experiment (Section III-1.3). The materials tested were Type 304 stainless steel, Type 6061 aluminum, Teflon-TFE, Kel-F, Kynar, and Pyrex glass. Each sample was analyzed for the four isotopes, I-131, Te-132, I-133, and Mo-99, by gamma-ray spectroscopy. These isotopes were chosen because of their ease of analysis by gamma-ray spectroscopy, because of their high volatility, and because of their abundance (high yields).

The coupons were hung adjacent to each other on horizontal rods: in the containment vessel. This was done in order to detect concentration gradients along the rods and to determine, approximately, a value for these gradients. After exposure, the coupons were examined for activity without decontamination. 
The results of the analyses are listed in Table XXXVII and indicate (by the agreement of analyses of three samples of each of the materials) that concentration gradients of these four isotopes along the rods holding the coupons are nearly zero; therefore, in this particular region of the containment vessel, good mixing was attained. Thus, the variation in activities observed between material types cannot be ascribed to variations in concentrations of these isotopes in the atmosphere.

\section{TABLE XXXVII}

TOTAL ACTIVITY ON COUPONS TESTED FOR FISSION PRODUCT SORPTION (dps)

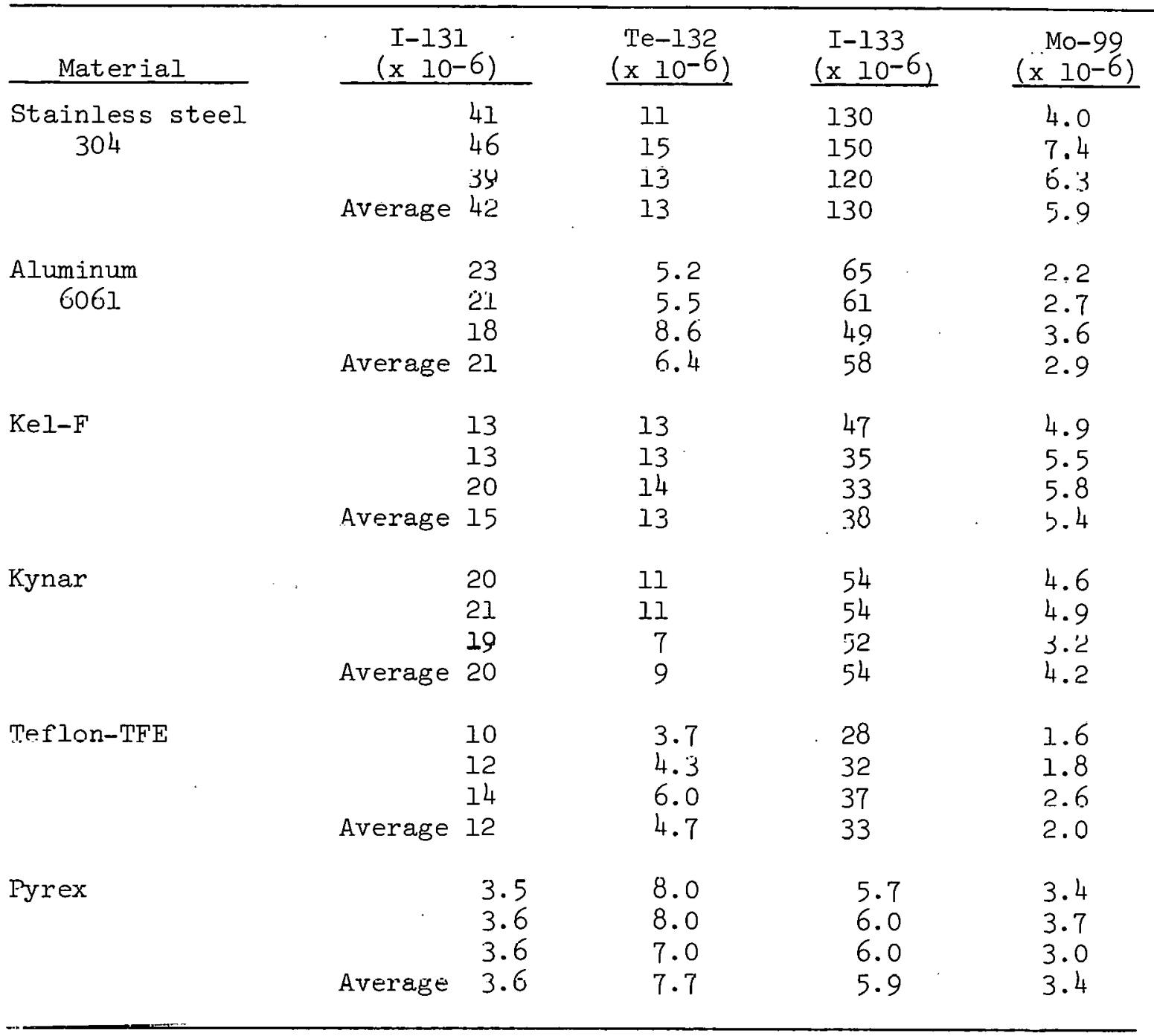

In general, the results indicate that, of the materials tested, stainless steel has the highest retention of these isotopes. On the average the activity on the stainless steel coupons was 2.1 times the average activity on the other materials (excluding Pyrex which retained the least activity of any). There were no significant differences in the retention of these isotopes by Kel-F, Kynar, Teflon, and aluminum. The fact that aluminum retains these fission products to the same extent as the organic polymers Kel-F, Kynar, and Teflon would indicate that the mechanism of isotope retention is not predominatly a chemical one. 
Of the materials tested, Pyrex has the most desirable isotope retention behavior. Its average retentive ability is a factor of 3.7 below that of $\mathrm{Kel}-\mathrm{F}$, Kynar, Teflon, and aluminum and a factor of 7.8 below that of stainless steel.

The CSM is currently constructed of Teflon-TFE. If this material should prove to be objectionable (eg, deterioration at high radiation levels), the results of this test will be reconsidered in the selection of a new material of construction.

\subsection{Evaluation of LOFT Plateout Capsules \\ (W. A. Freeby, D. P. Wright; Development Engineering Section)}

The fission product behavior in the LOFT containment building following the core meltdown will be determined largely through analyses of atmospheric and plateout samples taken with the LOFT capsule samplers. Two of the atmospheric and two of the plateout capsule samplers were tested in both CDE Runs 3 and 4. Results of the plateout capsule testing are reported in the following paragraphs, and the results of testing of the atmospheric (or gas-particulate) capsule are reported elsewhere [35].

The LOFT plateout capsule sampler (Figure 40) consists of a five-inchdiameter aluminum sphere containing a fixture for holding two 3/4-inch-diameter painted coupons. After a predetermined exposure period in the LOFT containment building, the coupons (held in aluminum cups) are retracted into the capsule. The capsules are then removed from the building for disassembly and analysis of the coupons.

The capsule samplers tested in the CDE were mounted on a rack as shown in Figure 41. In each of the tests performed, the plateout capsule samplers were exposed to the fission product aerosol for a 24-hour period in the CDE, and then closed. Following closure of the plateout capsules, the support rack and capsules were removed from the containment vessel and disassembled remotely in the CDE cell. The coupons were then placed in acetate cups for transfer to an

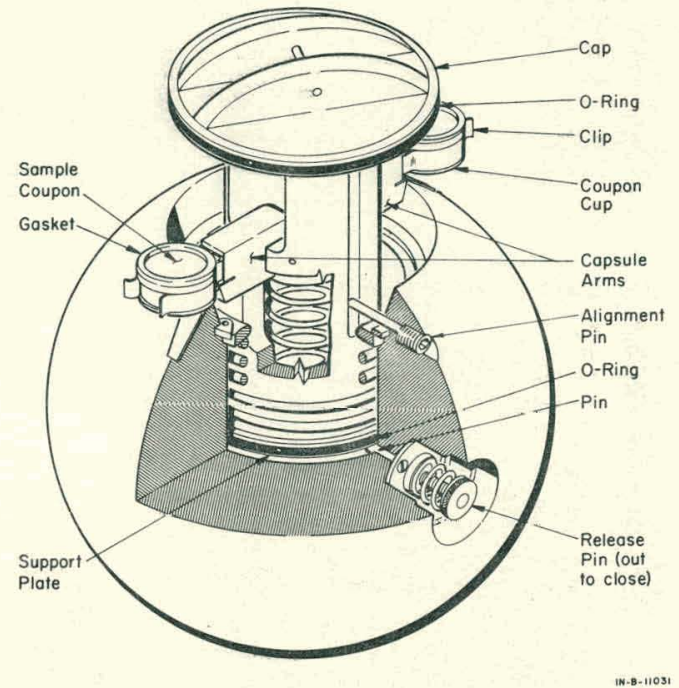

Fig. 40 LOFT plateout capsule assembly. adjoining hot cell. There, the coupons were sealed in plastic bags and transferred to a sample storage area.

The primary objective of the testing of the plateout capsules in the CDE to date is to determine if the data obtained from the plateout capsules are meaningful. To accomplish this, the effects of numerous variables (storage, handling, water immersion, capsule orientation, temperature, and condensation) are being studied. Since only two plateout capsules can be tested in each CDE run, other deposition samplers have been installed to augment the capsule evaluation. Two of the plateout capsules were installed for test in CDE Run 2; however, mechanical problems prevented them from operating. The improved units tested in CDE Runs 3 and 4 operated satisfactorily. The results of tests made to date are summarized in the following paragraphs. 


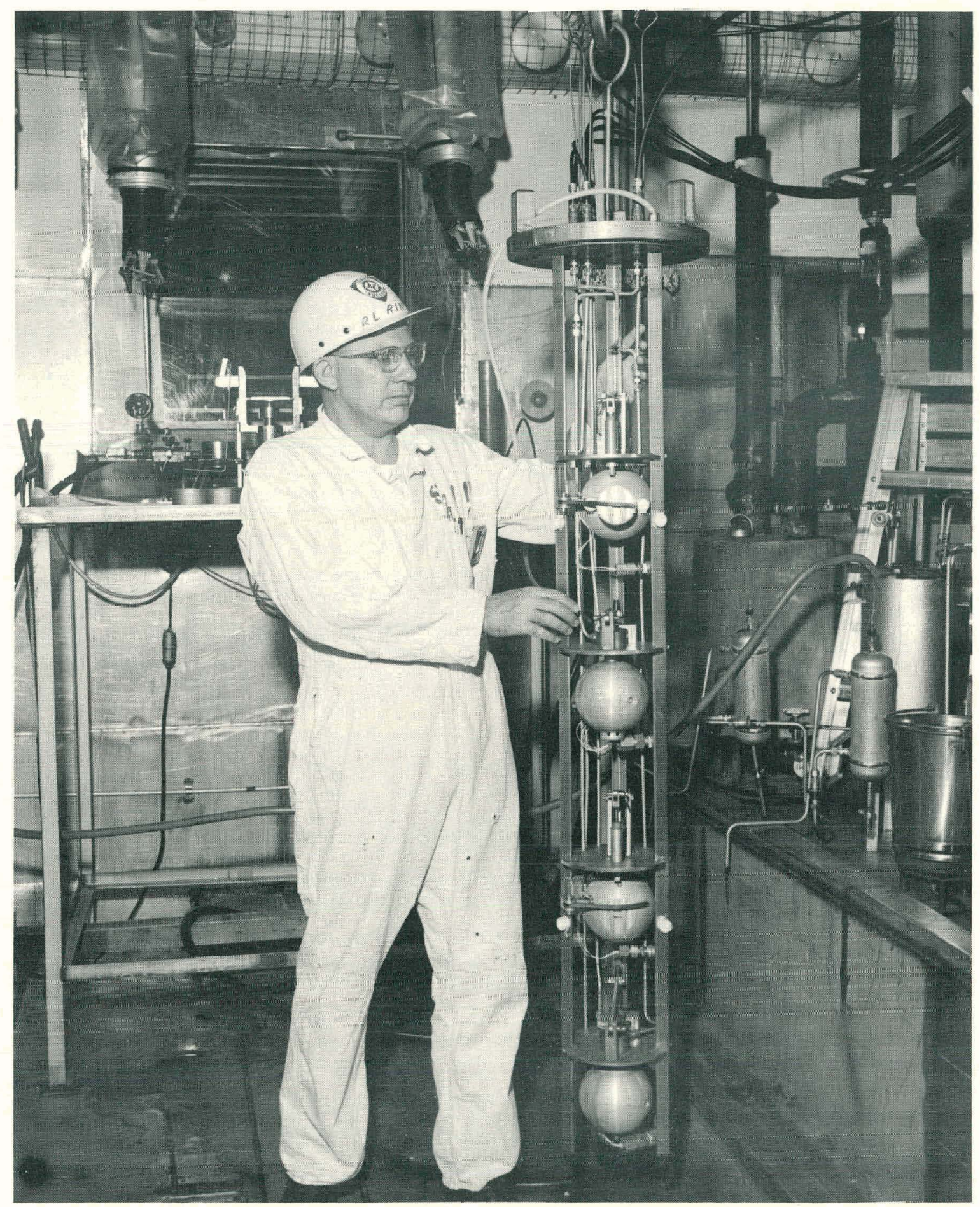

Fig. 41 Capsule support rack for CDE contain ment vessel.

1.61 Variation of Fission Product Deposition on Coupons Contained Within Same Capsule. The fission product activities on the capsule coupons from CDE Runs 3 and 4 are listed in Table XXXVIII. The activities on coupons from the same capsule compare reasonably well, with the maximum variation from an average value for any one capsule being less than 50 percent. However, somewhat more variation is apparent between analyses on coupons from different capsules. Nonhomogeneity of the containment vessel atmosphere may be contributing to this latter variation. 
TABLE XXXVIII

COMPARISON OF FISSION PRODUCT DEPOSITION ON CAPSULE COUPONS

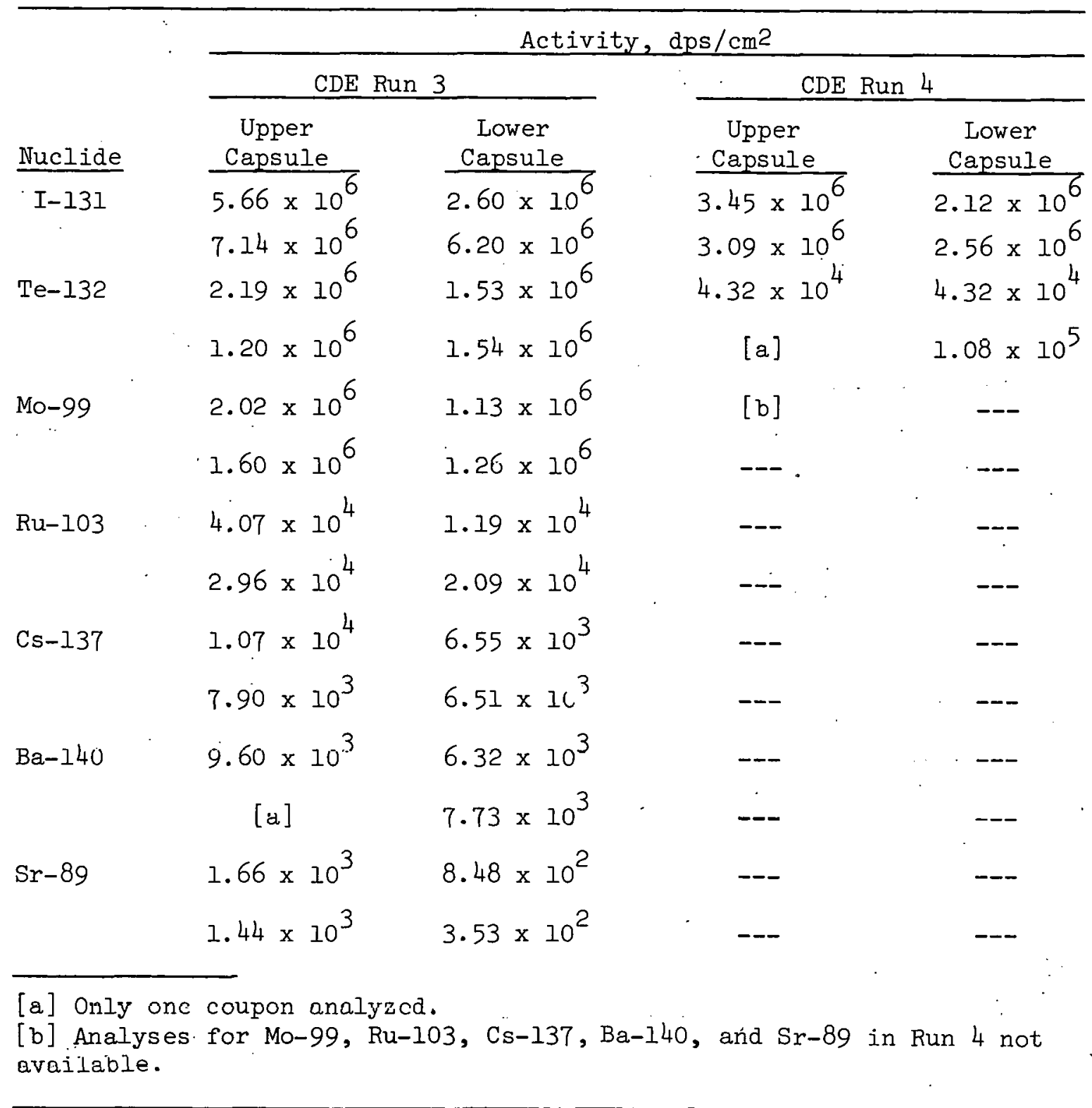

1.62 Effect of the LOFT Capsule on Fission Product Deposition. The presence of the spherical LOFT plateout capsule may affect the amount of fission deposited on its sample coupons. To determine the extent of this effect, numerous painted coupons in Teflon cups were attached to the capsule support structure, adjacent to, but outside of the capsules. 'These samples were exposed in CDE Runs 3 and 4. The exterior coupons and the coupons from the capsules were removed and packaged at the same time using identical procedures.

The activities on the capsule and exterior coupons are compared in Table XXXIX. The effect of the capsule on fission product deposition appears to be small. though the activities on the exterior coupons are generally higher than 
COMPARISON OF FISSION PRODUCT DEPOSITION ON COUPONS INSIDE AND OUTSIDE OF CAPSULES FOR CDE RUNS 3 AND 4

\begin{tabular}{|c|c|c|c|c|}
\hline \multirow[b]{2}{*}{ Nuclide } & \multicolumn{2}{|c|}{$\begin{array}{l}\text { Average Deposition on } \\
\text { Plateout Coupons Inside } \\
\text { Capsules dps/cm² }[\mathrm{a}, \mathrm{b}]\end{array}$} & \multicolumn{2}{|c|}{$\begin{array}{c}\text { Average Deposition on Plateout } \\
\text { Coupons Mounted on Support } \\
\text { Rack dps/cm } 2[\mathrm{a}, \mathrm{b}] \\
\end{array}$} \\
\hline & Upper Capsule & Lower Capsule & Upper Location & Lower Location \\
\hline \multicolumn{5}{|l|}{ Run 3} \\
\hline I-131 & $6.40 \times 10^{6}$ & $4.40 \times 10^{6}$ & $6.43 \times 10^{6}$ & $5.54 \times 10^{6}$ \\
\hline $\mathrm{Te}-132$ & $1.70 \times 10^{6}$ & $1.54 \times 10^{6}$ & $6.37 \times 10^{6}$ & $1.66 \times 10^{6}$ \\
\hline Mo-99 & $1.81 \times 10^{6}$ & $1.20 \times 10^{6}$ & $5.60 \times 10^{6}$ & $8.2 \times 10^{5}$ \\
\hline $\mathrm{Ru}-103$ & $3.52 \times 10^{4}$ & $1.64 \times 10^{4}$ & $8.77 \times 10^{4}$ & $2.47 \times 10^{4}$ \\
\hline \multicolumn{5}{|l|}{ Run 4} \\
\hline$I=131$ & $3.27 \times 10^{6}$ & $2.34 \times 10^{6}$ & $3.60 \times 10^{6}$ & $3.17 \times 10^{6}$ \\
\hline Te-132 & $4.32 \times 10^{4}$ & $7.6 \times 10^{4}$ & $2.73 \times 10^{5}$ & $5.18 \times 10^{5}$ \\
\hline Mo-99 & --- & --- & $1.44 \times 10^{5[\mathrm{c}]}$ & $3.28 \times 10^{5[\mathrm{c}]}$ \\
\hline $\mathrm{Ru}-103$ & --- & --- & --- & --- \\
\hline \multicolumn{5}{|c|}{$\begin{array}{l}\text { [a] Values reported are arithmetic average of two analyses. } \\
\text { [b] Values for Run } 3 \text { calculated back to time of. reactor shutdown; values } \\
\text { for Run } 4 \text { calculatiten hark to end of fuel. pin mcltdown. } \\
\text { [c] Oniy one value reported. }\end{array}$} \\
\hline
\end{tabular}

those on the capsule coupons. Possible reasons for the observed differences are shielding of the coupons by the capsule, shorter exposure period for the capsule coupons, and migration of fission products within the capsules. The shlelding effect appears most probable. Though the exterior coupons were exposed to the containment atmosphere for several hours longer than coupons in the capsule, the fission product concentrations in the containment vessel had greatly decreased in the later stages of the exposure. Preliminary data on migration of fission products within the capsule make migration an unlikely pussiblitty. Additional comparisons of this type are planned for future CDE runs.

1.63 Effect of Coupon Orientation on Fission Product Deposition. To determine the effect of surface orientation on fission product deposition, the surfaces of painted coupons were oriented in various directions (facing up, down, or sideways) and attached to three levels (top, middle, or bottom) of the capsule support rack in the containment vessel. The major isotopes found on each coupon contaminated in CDE Run 4 are listed in Table XL with the corresponding orientation of the coupon. It appears that only the coupons with the surfaces facing up show substantial deviation from the average deposttion found on 
EFFECT OF COUPON ORIENTATION ON FISSION PRODUCT DEPOSITION[a] FOR CDE RUN 4

\begin{tabular}{|c|c|c|c|c|}
\hline \multirow[b]{2}{*}{ Coupon Location } & \multirow[b]{2}{*}{ Orientation } & \multicolumn{3}{|c|}{ Coupon Activity, $\mathrm{dps} / \mathrm{cm}^{2}$} \\
\hline & & $I-131$ & $\mathrm{Te}-132$ & Mo-99 \\
\hline Top level & Facing up & $9.9 \times 10^{6}$ & $4.32 \times 10^{6}$ & $1.95 \times 10^{6}$ \\
\hline Top level & Facing down & $4.14 \times 10^{6}$ & $3.27 \times 10^{5}$ & $1.49 \times 10^{5}$ \\
\hline Top level & Facing to side & $3.90 \times 10^{6}$ & $2: 04 \times 10^{5}$ & $1.12 \times 10^{5}$ \\
\hline Middle level & Facing up ${ }^{[\mathrm{b}]}$ & $3.26 \times 10^{6}$ & $2.23 \times 10^{5}$ & $9.90 \times 10^{4}$ \\
\hline Middle Ievel & Facing down & $4.25 \times 10^{6}$ & $2.18 \times 10^{5}$ & 1. $27 . \times 10^{5}$ \\
\hline Middle level & Facing to side ${ }^{[c]}$ & $3.40 \times 10^{6}$ & $1.67 \times 10^{5}$ & $1.22 \times 10^{5}$ \\
\hline Bottom. level & Fàcing up & $9 \cdot 76: x: 10^{6}$ & $3.69 \times 10^{6}$ & $1.34 \times 10^{6}$ \\
\hline Bottom level: & Fracing down & $3.35 \times 10^{6}$ & $2.73 \div x \cdot 10^{5}$ & $1.51 \times 10^{5}$ \\
\hline Bottom leviel & Facing to side ${ }^{[c]}$ & $4.30 \times 10^{6}$ & $3.79 \times 10^{5}$ & $1.72 \times 10^{5}$ \\
\hline
\end{tabular}

[a] Three-quarter-inch-diameter aluminum coupons painted with Amercoat66.

[b] Believed to be in error -- orientation was probably "downward".

[c] Average of 4 to 6 coupons located in a vertical position. The coupons were either facing or perpendicular to the CDE containment vessel wall at distances of 10 and 17 inches from the wall.

all surfaces. The coupons facing up show deposition levels of lodine two times higher than the other coupons. For particulates (Te-132, Mo-99), the deposition levels were up to ten timcs higher on the upward facing roupons.

A survey, shown in Table XLI, of the activities on the controlled temperature coupons contaminated in Runs 2 and 3 was made to obtain an independent check on the orientation data from Run 4. The controlled-temperature sampler, shown in Figure 42, uses 1-1/2 $\times 3 / 4 \times 3 / 16$ inch coupons oriented in various directions. With the exception of the iodine, the activities on these coupons exhibit the same general trend, although not. as pronounced, as those on the capsule coupons in Run 4.

1.64 Effect of Temperature and Condensation on Fission Product Deposition. The studies on deposition of fission products on heated and cooled, controlled temperature coupons [1] were continued in Run 3. The procedure used was similar to that used in Runs 1 and 2 except that smaller temperature differences between the contalnment atmosphere and the coupons were maintained. In Run 3, the average temperature differences between the heated and cooled coupon surfaces 
EFFECT OF ORIENTATION ON FISSION PRODUCT DEPOSITION ON CONTROLLED TEMPERATURE COUPONS[a] FOR CDE RUNS 2 AND 3

\begin{tabular}{|c|c|c|c|c|c|c|}
\hline \multirow{3}{*}{$\frac{\text { Run }}{2}$} & \multirow{3}{*}{$\frac{\text { Sampler }}{\text { Hot }}$} & \multirow{4}{*}{$\begin{array}{l}\begin{array}{c}\text { Coupon } \\
\text { Orientation }\end{array} \\
\text { Facing up } \\
\text { Facing down }\end{array}$} & \multicolumn{3}{|c|}{ Activity, dps/coupon } & \multirow[b]{2}{*}{ Ru-103 } \\
\hline & & & \multirow{3}{*}{$\begin{array}{l}\frac{I-131}{9.6 \times 10^{10}} \\
8.5 \times 10^{10}\end{array}$} & \multirow{3}{*}{$\begin{array}{l}\frac{M 0-99}{1.1 \times 10^{9}} \\
0.8 \times 10^{9}\end{array}$} & $\mathrm{Te}-132$ & \\
\hline & & & & & $1.1 \times 10^{9}$ & $1.1 \times 10^{6}$ \\
\hline & & & & & $1.4 \times 10^{9}$ & $0.3 \times 10^{6}$ \\
\hline 2 & Culd & Facing up & $6.3 \times 10^{10}$ & $2.7 \times 10^{10}$ & $3.2 \times 10^{10}$ & $4.0 \times 10^{8}$ \\
\hline & & Facing down & $4.2 \times 10^{10}$ & $2.2 \times 10^{10}$ & $1.8 \times 10^{10}$ & $8.0 \times 10^{8}$ \\
\hline 3 & Hot & Facing up & $2.2 \times 10^{9}$ & $2.3 \times 10^{9}$ & $\times 10^{9}$ & $1.3 \times 10^{7}$ \\
\hline & & Facing down & $2.3 \times 10^{9}$ & $0.4 \times 10^{9}$ & $0.12 \times 10^{9}$ & $0.05 \times 10^{7}$ \\
\hline & & Facing to side & $2.0 \times 1 n^{y}$ & $0.6 \times 10^{9}$ & $0.14 \& 10^{9}$ & U. $\times 10^{7}$ \\
\hline 3 & Cold & Facing up & $2.8 \times 10^{9}$ & $2.2 \times 10^{9}$ & $\times 10^{9}$ & $9.0 \times 10^{6}$ \\
\hline & & Facing down & $2.8 \times 10^{9}$ & $2.5 \times 10^{9}$ & $0.4 \times 10^{9}$ & $7.0 \times 10^{6}$ \\
\hline & & Focing to side & $2.5 \times 10^{9}$ & $1.5 \times 10^{5}$ & $0.6 \times 10^{9}$ & $10.0 \times 10^{6}$ \\
\hline
\end{tabular}

[a] $1-1 / 2 \times 3 / 4 \times 3 / 16$ inch carbon atecl coupons coated with Amercoat-66.

were +4 and $-4^{\circ} \mathrm{F}$. respectively, compared with the average containment temperature. In Run 1 , these differences were +130 and $-35^{\circ} \mathrm{F}$, respectively, while in Run 2 the differences were +30 and $-30^{\circ} \mathrm{F}$, respectively. In Figure 43 , the data obtained in Run 3 are compared with the deposition data obtained with the controlled temperature coupons from Runs 1 and 2. Though the plots are based upon a limited amount of data, the difference in deposition behavior exhibited by the iodine over that of the particulate fission produots, Te-132 and Ru-103, is apparent. Iodine is plated (or absorbed) preferentially on the noncondensing or hot surface while the particulate fission products are deposited more on the condensing or cool surface. Mo-99 and Ba-140 data, though not shown on the figure, follow a pattern similar to that of $\mathrm{Te}-132$ and $\mathrm{Ru}-103$. The plots also indicate that the variation in fission product behavior is small for the small temperature differences $\left(\approx 5^{\circ} \mathrm{C}\right)$ expected between the plateout capsule coupons and the LOFT containment wall.

\subsection{Studies of Unirradiated Fuel Pin Meltdown Residues \\ (M. R. Fox; Chemistry Section)}

An unirradiated Zircaloy-2 clad $T \cap_{2}$ fuel pin, similur In degign and construction to those being used in the hot CDE runs, was melted by induction heating in a flowing steam atmosphere in the CDE furnace. Post-melt fuel studies were made by X-ray powder methods, optical metallography, and microprobe analyses. The purpose of these studies was to develop an understanding of the behavior of this system under these conditions. Such areas as oxide formation and reduction of $\mathrm{UO}_{2}$ by $\mathrm{Zr}$ as well as the gross appearance and behavior of the residue were investigated. The data presented in this report must be considered as being preliminary inasmuch as this has been the first study of a meltdown under the conditions described. 


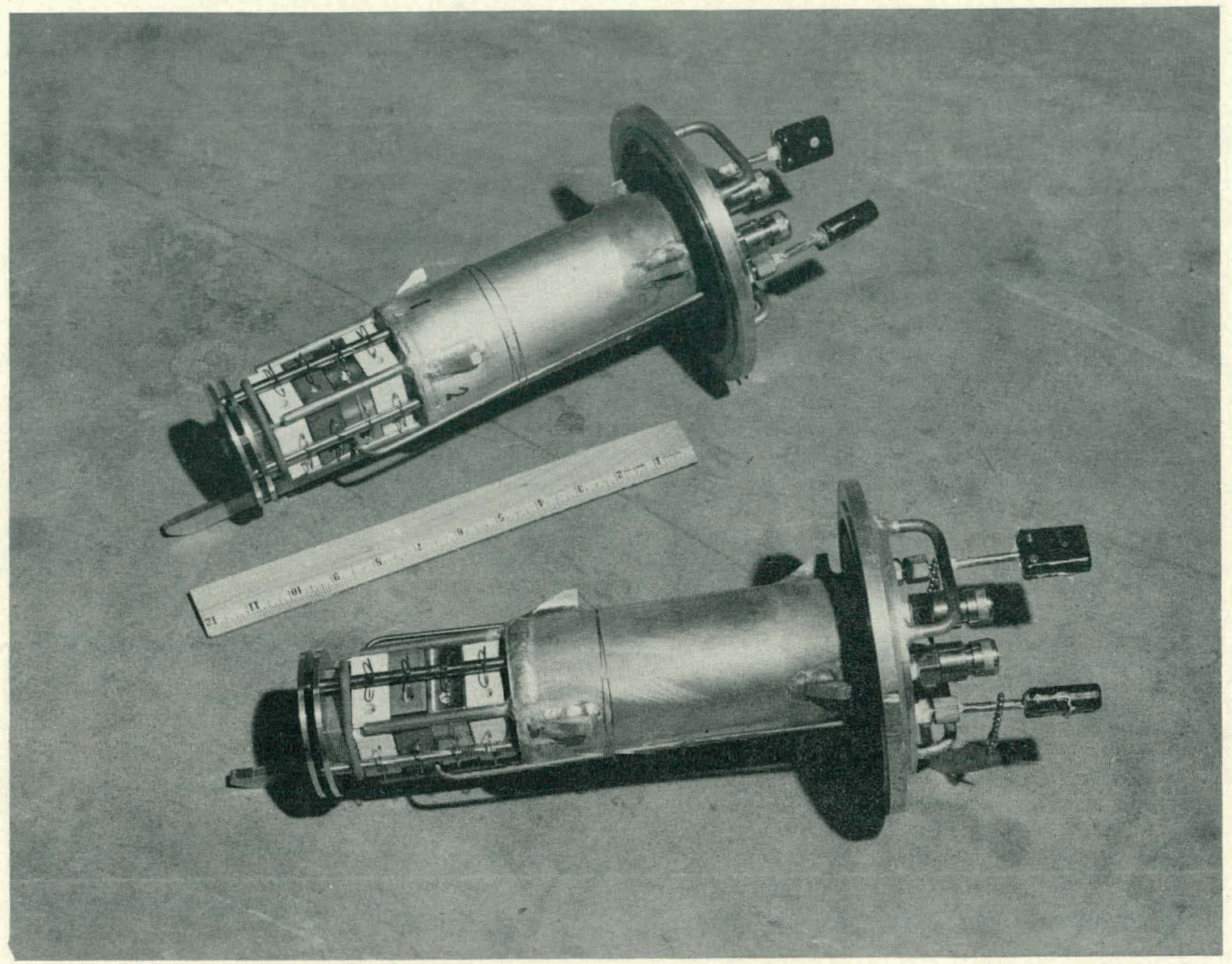

Fig. 42 Controlled-temperature sampler.

1.71 Experimental Conditions. The arrangement of the fuel pin and induction furnace is shown in Figure 44. 3team flowed from left to right through the quartz furnace tube and into the CDE containment vessel during meltdown at a rate of 1.75 feet/second. The steam contained about two percent argon which was introduced as purge gas in instrument lines.

The fuel pin was about 50 percent submerged in a bed of $\mathrm{UO}_{2}$ powder. This bed was used to prevent direct contact between the molten $\mathrm{UO}_{2}$ from the fuel pin and the quartz furnace tube. Molten $\mathrm{UO}_{2}$ wets quartz glass and upon cooling causes the glass to fracture. The $\mathrm{UO}_{2}$ bed does not become molten since it is in a cooler part of the furnace. The fuelpin residue was sectioned (perpendicular to the pin axis) for study by microprobe analyses and optical metallography.

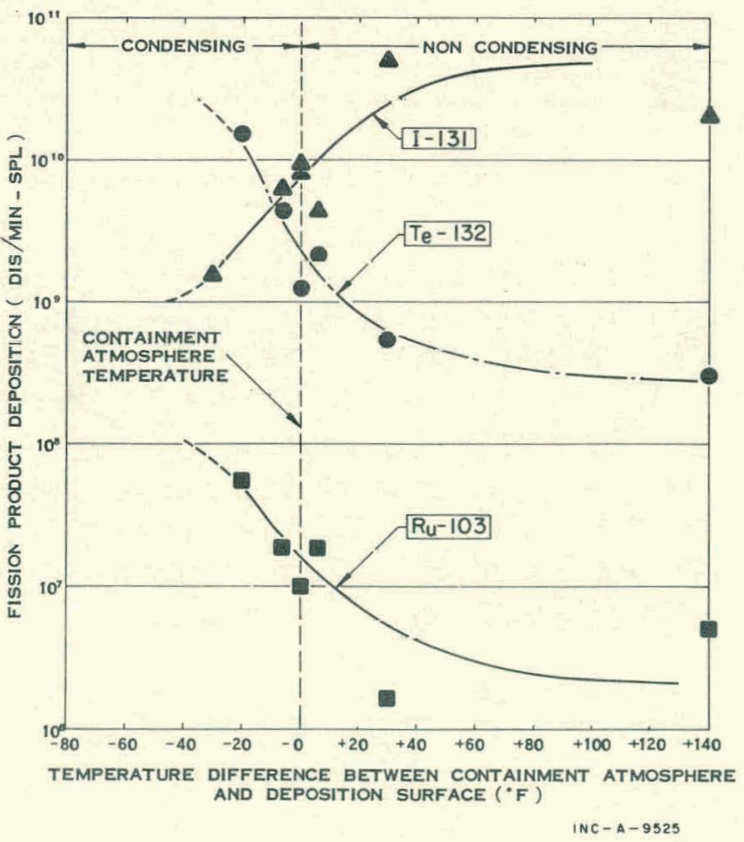

Fig. 43 Effect of temperature and condensation on fission product deposition. 


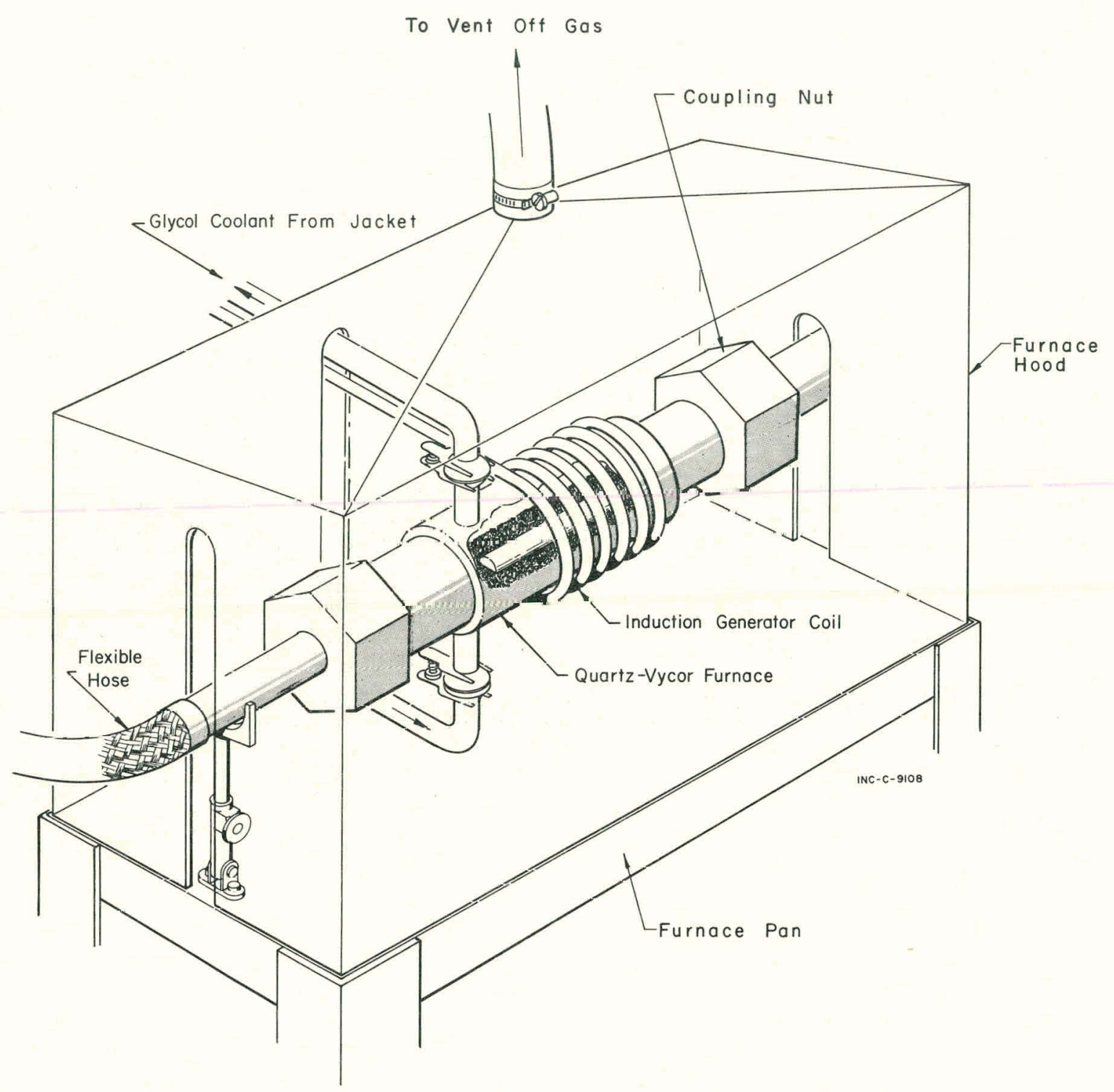

Fig. $44 \mathrm{CDE}$ induction furnace showing fuel pin in center of induction coil.

1.72 Results. Since about 50 percent of the pin was embedded in the $\mathrm{UO}_{2}$ powder, only the upper 50 percent was exposed to the flowing steam atmosphere. Most of the effort spent during this examination was in studying this upper portion.

Probably the most important observation is that the cladding of Zircaloy-2 on the upper half of the pin did not melt, but was completely oxidized to $\mathrm{ZrO}_{2}$ (melting point of Zircaloy -2 is $1850^{\circ} \mathrm{C}$ ). The oxidized Zircaloy -2 retained much of the original integrity of the cladding. It did fail by cracking, but not to the extent that might be expected.

The $\mathrm{UO}_{2}$ in the fuel pin showed much evidence of having been molten (melting point $\left.2830^{\circ} \mathrm{C}\right)$. This temperature was reached in approximately three minutes corresponding to a heating rate of $16^{\circ} \mathrm{C} / \mathrm{sec}$. The oxide $\mathrm{ZrO}_{2}$ (melting point $2690^{\circ} \mathrm{C}$ ), which formed from the metal-water reaction, had not melted significantly, even though it was in direct contact with molten $\mathrm{UO}_{2}$. The reasons for 
this stability are (a) heat loss from cladding by radiation, (b) cooling of cladding by the flowing steam, (c) failure of the $\mathrm{ZrO}_{2}$ to "couple" to the field of the induction furnace.

The appearance of metallic inclusions in the cladding $-\mathrm{UO}_{2}$ boundary region was also observed. They were tentatively identified as a uranium-zirconium alloy. According to Martin and Mrazek [41] when $\mathrm{UO}_{2}$ is heated above approximately $1500^{\circ} \mathrm{C}$ it has a tendency to become deficient in oxygen. When this substoichiometric mixture is cooled, metallic uranium is formed. Another possible explanation for the occurrence of metallic uranium is dependent upon the fact that at high temperatures $\mathrm{UO}_{2}$ and $\mathrm{ZrO}_{2}$ have almost identical free energies of formation [42].

For example,

$$
\begin{aligned}
& \Delta \mathrm{F}_{\mathrm{f}}\left(\mathrm{UO}_{2}, 2000^{\circ} \mathrm{K}\right)=-178 \mathrm{Kcal} \text { and } \\
& \Delta \mathrm{F}_{\mathrm{f}}\left(\mathrm{ZrO}_{2}, 2000^{\circ} \mathrm{K}\right)=-172 \mathrm{Kcal} .
\end{aligned}
$$

This, then, would make possible the reaction

$$
\mathrm{UO}_{2}+\mathrm{Zr}=\mathrm{ZrO}_{2}+\mathrm{U} \text {. }
$$

This possibility would be further enhanced if at least one of the constituents were molten (as was the situation in this experiment). In support of this latter postulate is the fact that the metallic uranium was found to always be accompanied by metallic zirconium in our observations. The $\mathrm{UO}_{2}$ matrix surrounding these $\mathrm{Zr}-\mathrm{U}$ inclusions contained $\mathrm{Zr}$ up to an estimated 18 weight percent. This matrix is probably a $\mathrm{UO}_{2}-\mathrm{ZrO}_{2}$ solid solution.

The lower half of the fuel pin which was not oxidized by the steam, had undergone complete melting. That is, both the fuel and the unoxidized cladding in this region had liquified and had mixed thoroughly in the $\mathrm{UO}_{2}$ bed.

1.73 Cunclusions. The physioal stability of the cladding which results from the rapid formation of $\mathrm{ZrO}_{2}$ could alter the fission product release factors under accident conditions. The skin of ceramic $\mathrm{ZrO}_{2}$ covering the fuel might keep the individual fuel pins, and therefore the core, somewhat intact and serve as a diffusion barrter and as a chemical trap for fission products volatilized from the fuel. The effect of the stability of the cladding should be studied further.

\subsection{High Temperature Properties of Materials}

(R. R. Hammer; Chemistry Section)

A report, IN-1093 [43], has been issued which reviews the physical properties of $\mathrm{UO}_{2}, \mathrm{ZrO}-\mathrm{JO}_{2}$ solid solutions, $\mathrm{ZrO}_{2-\mathrm{x}}$, and Zircaloy-4. Recommended, measured, and extrapolated values for these properties are given. The properties covered include transition temperatures, heat capacities, heat contents, vapor pressures, thermal conductivities, and thermal expansion. The temperature ranges and materials covered were selected for use in the analysis of a loss-ofcoolant accident. 


\section{OTHER REACTOR TECHNOLOGY SUPPORT PROGRAMS}

2.1 A new Process for Uranium Aluminide Manufacture Employing Fluidized Bed Techniques

(E. S. Grimmett, R. K. Ballard; Development Engineering Section)

A method has been developed for producing uranium aluminide $\left(\mathrm{UAl}_{3}\right)$ in a fluidized bed reactor using uranyl nitrate and aluminum as starting materials. Uranium aluminide compounds have properties which make them desirable as fuels in test reactors, or even power reactors. This process eliminates several of the steps normally used in the manufacture of uranium aluminide compounds and lends itself particularly well to an on-site fuel cycle.

2.11 Uranium Aluminides as Reactor Fuels. There are three uranium aluminide compounds of interest to the reactor engineer. These compounds, along with some of their important properties, are shown in Table XLII..UAl 3 has been made by the fluldized bed process, and it is prohahle that $\mathrm{UAl}_{2}$ and $\mathrm{UAl}_{4}$ can be made as well.

TABLP XLII

PROPERTIES OF URANIUM-ALUMINIDES

\begin{tabular}{|c|c|c|c|c|}
\hline Compound & $\begin{array}{c}\text { Theoretical } \\
\text { Density } \\
\mathrm{g} / \mathrm{cm}^{3} \\
\end{array}$ & $\begin{array}{l}\text { Uranium } \\
\text { Content } \\
\mathrm{g} / \mathrm{cm}^{3} \\
\end{array}$ & $\begin{array}{l}\text { Melting } \\
\text { Point }{ }^{\circ} \mathrm{C} \\
\end{array}$ & Crystal Structure \\
\hline $\mathrm{UAl}_{2}$ & 8.14 & 6.64 & 1590 & Face Centered Cubic \\
\hline $\mathrm{UAl}_{3}$ & 6.80 & 5.08 & 1350 & Face Centered Cubic \\
\hline $\mathrm{UAl}_{4}$ & 6.06 & 4.16 & 730 & Orthorhombic \\
\hline
\end{tabular}

Gibson and deBoisblanc [44] proposed that uranium aluminide compounds be used with powdered aluminum to make uranium-rich fuel elements by powder metallurgy techniques. When used in reactors operating with high heat fluxes and power densities, such as the Engineering Test Reactor and the Advanced Test Reactor, these fuels offer advantageous properties not available in other fuels. Some of the advantages of such fuels are as follows:

(1) Good control can be obtained over the amounts of uranium and boron present in fuel plates by using this technique.

(2) A remarkable ability to retain fission gases has been shown by $\mathrm{UAl}_{4}$, the compound to which the other aluminides convert when used in an aluminum matrix.

(3) Fuel plates made by this powder metallurgy technique are very stable.

(4) Thc estimated thermal conductivities of these compounds are about eight times those of uranium oxides. 
The uranium aluminide compounds $\mathrm{UAl}_{2}$ and $\mathrm{UAl}_{3}$ have relatively high melting points and high thermal conductivities. These properties make these compounds attractive for use instead of $\mathrm{UO}_{2}$ in clad tube-type fuel elements. Without the aluminum matrix, these compounds would not convert to the lower melting $\mathrm{UAl}_{4}$.

2.12 Process Steps Carried Out In Fluidized Bed Reactor. $\mathrm{UAl}_{3}$ has been produced at this laboratory from starting materials of uranyl nitrate and aluminum powder by using fluidized bed techniques. No metallic uranium is handled anywhere in the process, and the product leaves the process in its desired size and shape.

In the studies made to date, the product has consisted primarily of welldefined spherical particles of relatively pure $\mathrm{UAl}_{3}$. Presumably, $\mathrm{UAl}_{2}$ or $\mathrm{UAl}_{4}$ can be produced equally as well by adjusting the aluminum-to-uranium ratio in the first step. The conversion is based on four consecutive chemical reactions:

$$
\begin{aligned}
& \text { (1) } \mathrm{UO}_{2}\left(\mathrm{NO}_{3}\right)_{2} \frac{\Delta}{350^{\circ} \mathrm{C}} \mathrm{UO}_{3} \\
& \text { (2) } \mathrm{UO}_{3} \frac{\mathrm{CH}_{3} \mathrm{OH}}{350^{\circ} \mathrm{C}} \rightarrow \mathrm{UO}_{2} \\
& \text { (3) } \mathrm{UO}_{2} \frac{\mathrm{CCl}_{4}}{3500 \mathrm{C}} \mathrm{UCl}_{3} \\
& \text { (4) } \mathrm{UCl}_{3}+4 \mathrm{Al} \frac{\Delta}{600^{\circ} \mathrm{C}} \mathrm{UAl}_{3}+\mathrm{AlCl}_{3} .
\end{aligned}
$$

These reactions are carried out in four consecutive steps in a fluidized bed reactor.

The first step is basically a calcining operation in which a uranyl nitrate solution is converted to the trioxide $\left(\mathrm{UO}_{3}\right)$. A starting bed of spherical aluminum particles $(-250+325$ mesh $)$ is charged to the reaction vessel. The bed is fluidized with air and the lemperature brought to $350^{\circ} \mathrm{C}$. An aquenus solution of uranyl nitrate is sprayed through an atomizing nozzle into the hot bed of fluidized alum1num particles where it decomposes to $\mathrm{UO}_{3}$ as it is deposited on the particles. The laminar oxide coating is built up until the desired weight ratio of uranium to aluminum is attained.

In the second step, the uranium trioxide is reduced with methanol to uranium dioxide so that, during the subsequent chlorination step, undesirable side reactions can be minimized. Other reductants could be used, but with methanol the reaction takes place readily at a low temperature of $350^{\circ} \mathrm{C}$. During this step the bed is fluidized by argon gas which is mixed with methanol vapors in a vaporizerpreheater. When the reduction reaction is completed, the bed consists of discrete spheres of aluminum cores surrounded by a uniform coating of uranium dioxide.

Experiments being conducted at the present time indicate that the addition of small amounta of boron ( 0.5 part.s horon to 100 parts uranium) to the uranyl 
nitrate feed enhances the formation of an amorphous form of $\mathrm{UO}_{3}$. The amorphous form of $\mathrm{UO}_{3}$ reacts readily with carbon tetrachloride and can be chlorinated directly without being first reduced to $\mathrm{UO}_{2}$. Since the boiling point of boron trichloride is $12.5^{\circ} \mathrm{C}$, it presumably vaporizes during the chlorination step. Its exact fate, however, is not known. If this new approach is successful, the second step in the process can be eliminated and, thus, the cost of producing uranium aluminide by this process will be reduced further.

Chlorination of the uranium oxide to uranium trichloride takes place in the third step. The bed temperature is again held at $350^{\circ} \mathrm{C}$, and carbon tetrachloride is introduced into the bed as a vapor mixed with the argon fluidizing gas. As with the methanol, the carbon tetrachloride is metered as a liquid into a vaporizer-preheater. During this step the feed rate of the carbon tetrachloride must be carefully controlled because the reaction between the carbon tetrachloride and uranium oxide is highly exothermic.

After all of the uranium nxire has been oonverted to uranlum lrichloride, the fourth step is begun by raising the temperature of the bed to $600^{\circ} \mathrm{C}$, with argon gas used as the fluidizing merlinm. At this tomporature, the uranlum trichloride coating reacts with the aluminum core to form $\mathrm{UAl}_{3}$ and volatile aluminum chloride. The bed now consists of hollow, nearly spherical particles of pure $\mathrm{UAl}_{3}$. These particles probably can be densified by passing them through a plasma arc flame. Although tests on uranium aluminide particles have not been conducted, aluminum oxide particles of similar size and porosity have been passed through a plasma arc flame, resulting in a final density greater than 90 percent of theoretical.

2.13 Pilot Plant Equipment. Exploratory studies have been conducted on all four steps of this process on a pllot plant scale. The pilot plant equipment included both two- and four-inch-diameter fluidized bed reaction vessels. A flow diagram of the process using the four-inch-diameter fluidized bed reaction vessel is shown in Figure 45,

The reaction vessel is mare from etainloog steel and is fuur inches in diameter by four feet high. Heat is supplied to the vessel by an induction heater whose coils are positioned around the lower part of the insulated vessel. Spherical particles of aluminum are charged into the vessel through a hopper located in the top of the vessel; any portion of the bed can be removed from the bottom of the vessel through a discharge pipe which passes through the fluidizing gas distributor plate. Uranyl nitrate solution and atomizing gas are metered into the vessel through a two-fluid atomizing nozzle placed below the surface of the fluidized bed of particles. The fluidizing gas, either argon or air, enters the vessel through the distributor plate at the bottom of the vessel. Prior to entering the reactor vessel, the fluidizing gas passes through a heated vaporizing chamber where either methanol or carbon tetrachloride is introduced at a controlled rate and mixed as a vapor with the fluidizing gas.

The off-gas from these four steps passes first through a cyclone where the bulk of the entrained fines are removed and, if desired, returned to the fluidized bed. Next, the off-gas passes through a venturi scrubber using water as the scrubbing agent, which removes condensible by-products and water from the offgas. This is followed by a high-efficiency filter which removes any dust from the 


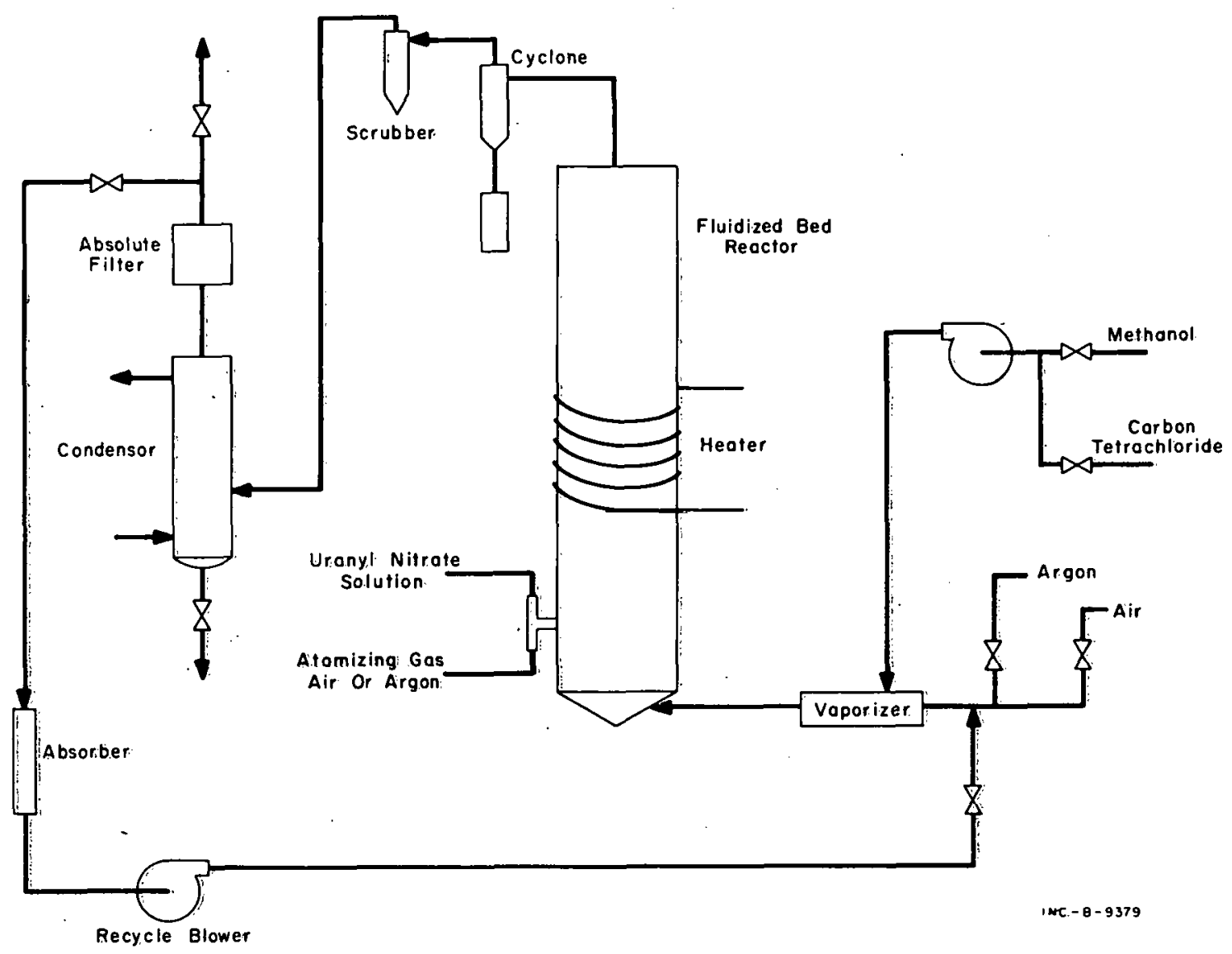

Fig. 45 Schematic flow sheet of apparatus for fluidized bed production of $\mathrm{UAl}_{3}$.

off-gas before the gas is discharged from the system. An off-gas recycle loop is provided to reduce argon consumption during the reduction, chlorination, and high temperature conversion steps of the process. The loop includes an absorber to remove any residual acid fumes before the gas reenters the reaction vessel.

2.14 Advantages of Process in Closed-Loop Fuel Cycles. Due to the direct use of uranyl nitrate solution as feed material and to the compactness of the processling equipment, use of the fluidized bed process leads to less costly fuel cycles by eliminating several steps from the conventional cycle. Several advantages are apparent in this abbreviated cycle:

(1) Costs are reduced by eliminating from the fuel cycle the necessity of converting the uranium to the metal. This eliminates many of the presently required processing and handling steps.

(2) Because the fluidized bed process produces the uranium aluminide in an ideal spherical form, no further grinding or sizing is required. No large amounts of off-sized product must be returned to the process.

(3) Uranium aluminide particles ready for use by the fuel fabricator can be produced at an aqueous chemical processing plant by investing in only a small amount of additional equipment. 
(4) General health and radiation hazards are reduced by minimizing cross-country shipments of radioactive materials. (At the present time facilities for different steps of the fuel cycle are located at different sites.)

(5) Chemical reprocessing costs can be reduced because product specifications could be established by the reprocessor to meet only those required by his particular fuel fabrication operation.

(6) Any reject material created in the process is directly and automatically re-introduced into the process. For example, the fines from the cyclone are automatically returned to the reactor vessel, and the scrub solution from the venturi scrubber is recycled back to the uranyl nitrate feed stream. With the present processes, recycle of reject material involves many material handling problems.

(7) The process has the inherent flexibility for custom manufacture of a wide variety of spherical particle-type fuels. This includes many types of fuel inalerluls, as well as possible additions of burnable poisons. The fluidized bed technology developed for this process appears adaptable to the production of many other types of reactor fuel materials ouoh as oxldes, curbides, silicides, nitrides, and other binary fuel compounds.

\subsection{Removal of Boehmite Coating from ATR Fuel Elements}

(C. A. Zimmerman; Chemistry Section)

A chemical cleaning procedure for the removal of boehmite ( $\alpha$ monohydrate of alumina) coating from the aluminum clad surfaces of ATR fuel elements was proposed since the accumulated oxide of low thermal conductivity could shorten the service life of the fuel elements. This procedure consisted of a one-hour immersion in boiling $1.0 \mathrm{M}$ phosphoric acid $-0.4 \mathrm{M}$ chromium trioxide solution to. be followed by a three minute immersion in boling throc molar ullide acld if the phosphate - chromate' surface fllm formed in the first step could not be tolerated in reactor operation. Table XLIII shows the proposed test reactor fuel cycle with film removal between irradiation periods. In general, test reactor fuel elements are moved from one core position to another in the middle of their irradiation life.

\section{TABLE XIIII}

\section{TEST REACTOR FUEL CYCLE}

Element Fabrication

First Irradiation.

Film Removal

Conditioning in Nitric Acid

Additional Steps if Film Removal is Required

Storage in Basin

Second Irradiation

Reprocessing 
Results of laboratory investigation of aluminum corrosion losses in solutions of various concentrations of the cleaning reagents are reported in Table XLIV. All of these appeared acceptable from a corrosion point of view. The $1 \mathrm{M}$ phosphoric acid - $0.4 \mathrm{M}$ chromium trioxide solution is generally preferred for oxide removal.

\section{$\underline{\text { TABLE XLIV }}$}

CORROSION OF TYPE 6061-0 ALUMINUM BY PHOSPHORIC ACID-CHROMIUM TRIOXIDE SOLUTION

\begin{tabular}{|c|c|c|c|c|}
\hline & Corre & $n$ (Mils p & osure & od) \\
\hline & One $\mathrm{Hou}$ & xposure & Two $\mathrm{H}$ & Exposure \\
\hline & $80^{\circ} \mathrm{C}$ & Boiling & $80^{\circ} \mathrm{C}$ & Boiling \\
\hline $0.5 \mathrm{M} \mathrm{H}_{3} \mathrm{PO}_{4}-0.2 \mathrm{M} \mathrm{CrO}_{3}$ & 0.009 & 0.012 & 0.004 & 0.010 \\
\hline $1.0 \mathrm{M} \mathrm{H}_{3} \mathrm{PO}_{4}-0.4 \mathrm{M} \mathrm{CrO}_{3}$ & $0.008^{[a]}$ & $0.009^{[b]}$ & 0.019 & 0.026 \\
\hline $1.0 \mathrm{M} \mathrm{H}_{3} \mathrm{PO}_{4}-0.2 \mathrm{M} \mathrm{CrO}_{3}$ & 0.009 & 0.011 & --- & - \\
\hline $1.0 \mathrm{M} \mathrm{H}_{3} \mathrm{PO}_{4}-0.6 \mathrm{M} \mathrm{CrO}_{3}$ & 0.005 & 0.011 & --- & -- \\
\hline
\end{tabular}

[a] Average of two determinations.

[b] Average of twelve determinations.

All others were single measurements.

Removal of the boehmite coating using phosphoric acid - chromium trioxide solution leaves a phosphate - chromate surface film. The amount of phosphorus that could be introduced to the reactor cooling water by this film is very small but could possibly accumulate during reactor operation. Table XLV lists the phosphorus content of films as determined by actual dissolution of the films in boiling 3M nitric acid and analytical determination of the dissolved phosphorus. The phosphate-containing film can be removed from the aluminum surface by a three-minute treatment in bolling three-molar nitric acid. Aluminum loss due to this short treatment is nnt severe as shown in Table XLVI.

\section{TABLE XLV}

\section{PHOSPHORUS CONTENT OF FILM DEPOSITED ON 6061-0 ALUMINUM}

\begin{tabular}{ll}
\hline \multicolumn{1}{c}{ Primary Exposure } & \multicolumn{1}{c}{ Phosphorus Removed } \\
\hline $\begin{array}{l}\text { One Hour in Bolling } \\
\text { Solution as Follows: }\end{array}$ & Five Minutes in \\
$1.0 \mathrm{M} \mathrm{H}_{3} \mathrm{PO}_{4}-0.2 \mathrm{M} \mathrm{CrO}_{3}$ & $1.9 \times 10^{-5}$ gram per in ${ }^{2}$ \\
$1.0 \mathrm{M} \mathrm{H}_{3} \mathrm{PO}_{4}-0.4 \mathrm{M} \mathrm{CrO}_{3}$ & $2.5 \times 10^{-5}$ gram per in ${ }^{2}$ \\
$1.0 \mathrm{M}_{3} \mathrm{PO}_{4}-0.6 \mathrm{M} \mathrm{CrO}_{3}$ & $2.7 \times 10^{-5}$ gram per in ${ }^{2}$ \\
\hline
\end{tabular}




\begin{tabular}{|c|c|c|}
\hline \multirow[b]{2}{*}{ Prior Specimen Treatment } & \multicolumn{2}{|c|}{ Corrosion (Mils per Exposure Period) } \\
\hline & $\begin{array}{l}\text { Three Minute } \\
\text { Exposure } \\
\end{array}$ & $\begin{array}{l}\text { Five Minute } \\
\text { Exposure }\end{array}$ \\
\hline \multicolumn{3}{|l|}{$\begin{array}{l}\text { One Hour Exposure in a } \\
\text { Boiling Solution: }\end{array}$} \\
\hline $1.0 \mathrm{M} \mathrm{H}_{3} \mathrm{PO}_{4}-0.4 \mathrm{M} \mathrm{CrO}_{3}$ & $0.134^{[\mathrm{a}]}$ & $0.188^{[a]}$ \\
\hline 1. $0 \mathrm{M} \mathrm{H}_{3} \mathrm{PO}_{4}-0.2 \mathrm{M} \mathrm{CrO}_{3}$ & -- & 0.185 \\
\hline $1.0 \mathrm{M} \mathrm{H}_{3} \mathrm{PO}_{4}-0.6 \mathrm{M} \mathrm{CrO}_{3}$ & --- & 0.184 \\
\hline $1.0 \mathrm{M} \mathrm{H}_{3} \mathrm{PO}_{4}-0.4 \mathrm{M} \mathrm{CrO}_{3}$ & $0.187^{[\mathrm{b}]}$ & -- \\
\hline
\end{tabular}

Two specimens of Type 6061-0 aluminum which had been exposed in a reactor loop to build a boehmite film (1.0 and 0.75 mil. thick as determined by Dermatron measurements) were cleaned by the phosphoric acid - chromium trioxide treatment. One of these specimens was then treated with three-molar nitric acid to remove the phosphate - chromate coating. The two specimens were then subjected to an accelerated basin storage corrosion test by exposure for approximately 180 hours in $65^{\circ} \mathrm{C}$ distilled water that was aerated daily. The specimen that retained the phosphate - chromate coating showed very slight calculated corrosive attack and developed no coating of aluminum oxide. The specimen from which the phosphate - chromate coating was removed suffered a calculated corrosive attack of $0.16 \mathrm{mil}$ and developed a coating of approximately $0.3 \mathrm{mil}$ of bayerite ( $\beta$ trihydrate of alumina). Identification of the boehmite and bayerite forms of alumina was done by X-ray diffraction analysis which was also used to confirm the removal of boehmite from these specimens.

These tests have demonstrated the successful removal of boehmite from aluminum surfaces and the high probability of passivity of the surface under subsequent fuel storage conditions. The rate of accumulation of boehmite in a second exposure in a reactor environment after cleaning and simulated storage was no greater than originally. 


\section{NEW MODULAR PILOT PLANT LABORATORIES}

(S. J. Horn; Development Engineering Section)

Since 1953, chemical engineering development studies for the ICPP have been performed in a converted warehouse building, several miles removed from the processing plant. This laboratory-pilot plant building has a gross floor area of 12,000 square feet, of which only about one-half has been actually used for experiments. The balance of the building has been used for offices, shops, rest rooms, storage, and to house utilities generating equipment such as a1r compressors, water treating equipment, steam generators, etc.

Since the building was not originally designed as a pilot plant; facilities for the disposal of liquid wastes and the ventilation of experiments have been inadequate. As a consequence, general deterforation of the building and acceler ated attack of the experimental apparatus has occurred. In addition to these faults, the design of the building has meant that experiments were installed by assembling the appropriate components and piping, along with the supporting structure, inside the building. As a consequence, these experiments have tended to become permanent installations, regardless of the fact that the experiments would likely have a finite, and probably short, lifetime.

When the general condition of the area had reached a point where extensive renovation could no longer be avoided, it was estimated that the cost of repairing the laboratory would nearly equal the cost of constructing new facilities. This led to the design of new chemical engineering laboratories which are now under construction. The new development laboratories were designed around two basic criteria: (a) to provide as' clean an environment as practicable and (b) to use laboratory space as efficiently as practicable. It was felt that these criteria would be best met by employing a module concept in the design of experiments.

The basic feature of a modular experiment is that the experimental apparatus is assembled within a structural framework which serves both to support the entire experiment and to define its external dimensions. In general, the module would be a rectangular parallelepiped having standardized external dimensions. An experiment module can be completely built in a centralized shop area where most fabrication needs are readily available. When completed, the module is tested and callbrated in the shop before it is transported to the laboratory building. After the module has been transported to the laboratory building and installed, final connections to utilities and instrument consoles are made. In this manner, a minimum of construction activity occurs in the laboratory, and new experiments are put into operation with a minimum of interference with experiments already in operation. The reverse procedure is of equal importance. If laboratory space is needed, a temporarily idle experiment can be disconnected and the entire module removed and stored, essentially intact, for future use.

Two laboratory buildings have been designed for these modular experiments. One laburatory was designed for experiments which are tall, compared to the floor area occupied. Typical of such experiments are pulse columns and dissolvers. The second laboratory design is for experiments which do not require much overhead clearance. A High-Bay Laboratory has been designed and bullt and is presently being outfitted with experiment modules. The Low-Bay Laboratory, has been designed and construction is in progress. Both buildings have cement block walls, reinforced concrete floors with a protective coating, and a built-up metal deck roof. 
While the use of modular experiments is not unique to these facilities, the concept is so novel that essentially no design guidelines exist for efther the laboratories or the experiment modules. The ICPP laboratores have a number of common design features. Among these are a minimum ventilation rate of five complete building changes per hour, adequate drainage for all liquid wastes, a centralized utilities distribution system, and a separate off-gas system which is connected to the plant off-gas system. Similarly, those utilities and reagents available from the main ICPP systems will be supplied by these systems.

\section{THE HIGH-BAY LABORATORY}

The High-Bay Laboratory has overall inside dimensions of $32 \times 46$ feet with an overall free height inside of 36 feet. A 35- x 10-foot block of three offices occupies the central portion of the huilding, dividing it into two parallel bays. The roof of the office hlock is reinforoed and serves as a control mezzanine from which all experiments are operated. An open, stainless steel lined trench is provided for liquid wastes, and air is exhausted from the bullding through three roof exhaust fans.

Experimental modules are lowered into the laboratory through one of five roof hatches, each having an opening of $10 \times 9-1 / 4$ feet. The laboratory can be considered to be divided into eleven module spaces. However, one space is occupied by the fire protection sprinkler system and entrance door, and the space at the end of the office block is occupied by a permanent feed preparation system. In addition, one additional corner space is kept free for a second exit, leaving eight module spaces for ready use. While it is not likely that all eight modules will be in operation simultaneously, all spaces could be occupied by operable experiments.

Installation of modules in the High-Bay Laboratory has proved to be relatively easy, even with winds of un to $15 \mathrm{mph}$. The average llme required to install the four modules now in the laboratory was approximately one hour. 'The minimum elapsed time from when the module was lying on the transporting truck bed to when it was in position in the laboratory was one-half hour. Figures 46 through 49 show a sequence of installation of modules.

\section{THE LOW-BAY LABORATORY}

The Low-Bay Laboratory, scheduled for completion in the Spring of 1968, adjoins both the existing CPP-637 laboratory-office building and the recently completed High-Bay Laboratory. Upon completion of the Low-Bay Laboratory, the three laboratory buildings will be interconnected by a utilities tunnel in such a manner that utilities, process solutions, or instrument lines can be run from any laboratory building to the other. As a consequence, the extensive feed preparation system in the High-Bay Laboratory can be used to prepare special reagent solutions and feed them to an experiment in the High-Bay Laboratory, the Low-Bay Laboratory, or a CPP-637 laboratory. 


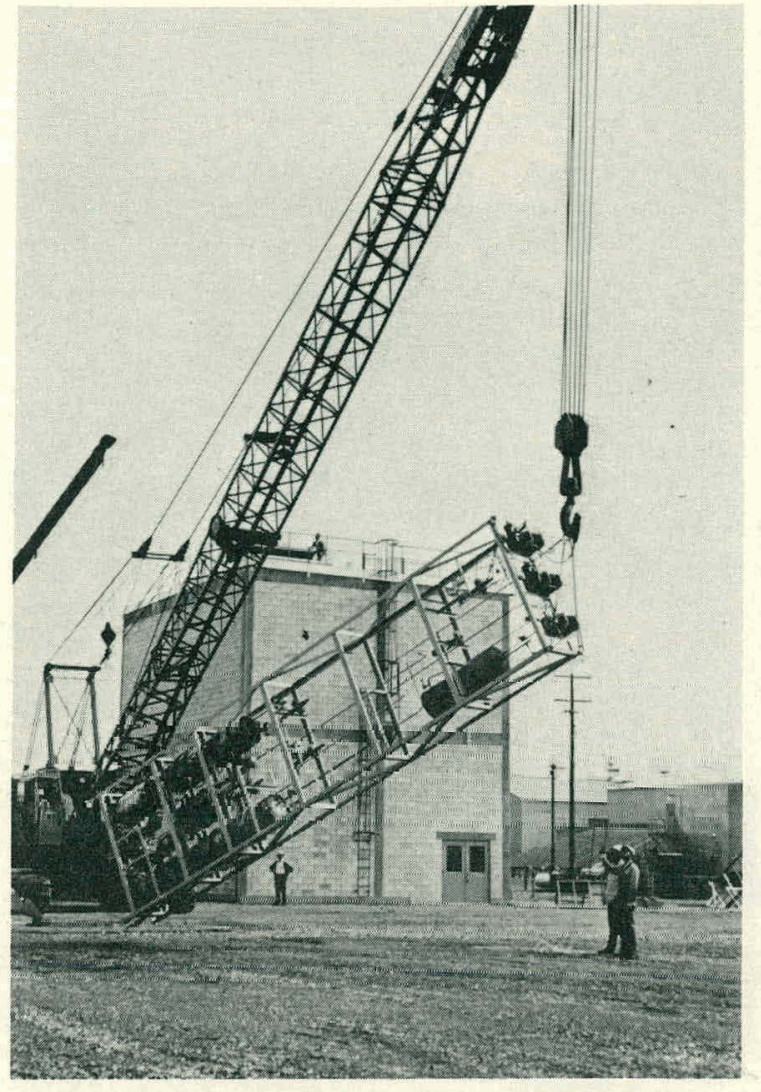

Fig. 46 Experimental module being lifted outside of high-bay lahoratory.

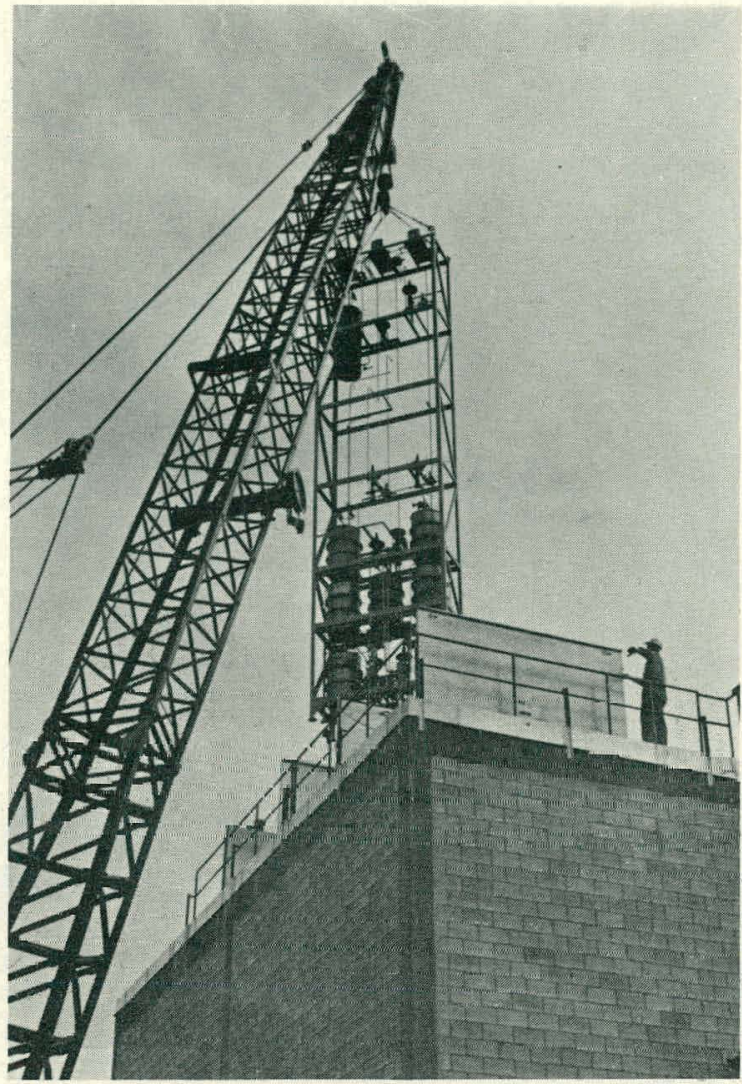

Fig. 47 Experimental module over open roof hatch of high-bay laboratory.

The Low-Bay Laboratory has basic internal dimensions of $105 \times 30$ feet, with a free inside height of 14 feet. The laboratory has space for twenty $8-\mathrm{x} 10-$ foot modules, and each module space has its own ventilation air supply and exhaust duct. Each module space is provided with a connection to each of the utilities lines and to the drain system. Experiment modules are rolled into the laboratory on wheeled bases.

The liquid waste system for this laboratory is buried under the floor and consists of a stainless pipe manifold; each module drain is capped except when in use. The ventilation system is designed to minimize contamination of the laboratory atmosphere with corrosive vapors; portions of an experiment can be enclosed in a shroud and connected to the ventilation exhaust duct to maintain adequate ventilation. In addition, the general flow of air, from the center of the laboratory to the walls, is designed to maintain a properly directed flow of ventilation air.

\section{ADVANTAGES OF THE MODULAR PLAN}

The modular concept for pilot plant experiments is felt to be the most efficient and flexible means of installing and operating such experiments for the following reasons: 


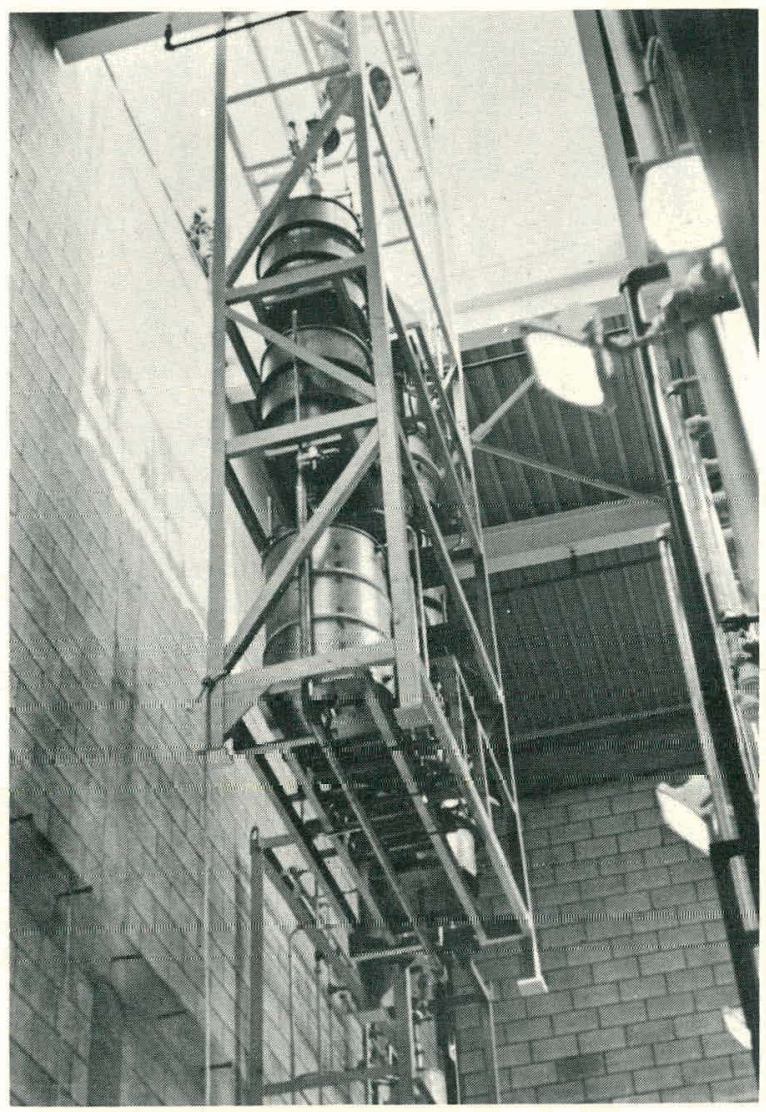

Fig. 48 Experimental module being lowercd into high-bay laboratory.

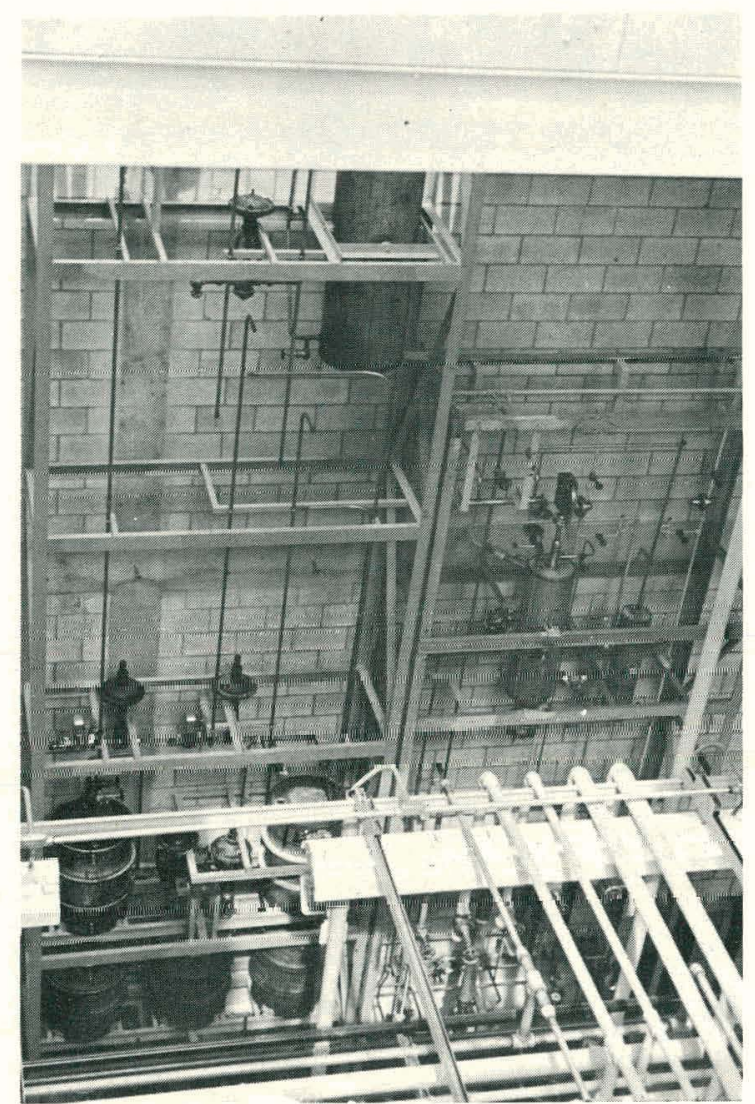

Fig. 49 Two experimental modules in place in high-bay laboratory.

(1) Lower costs in fabricating experiments since the construction work is done in the shops. This results in more efficient use of construction equipment and more efficient scheduling of craftsmen.

(2) Standardized design criteria for the experiment modules.

(3) More efficient utilization of laboratory space because of compact module design, elimination of most shop activity in the laboratory, and minimum interference with operating experiments.

(4) Extreme flexibility; the modules can be removed and stored, rebuilt and replaced, or salvaged. 


\section{v. ORGANIZATION CHART *}

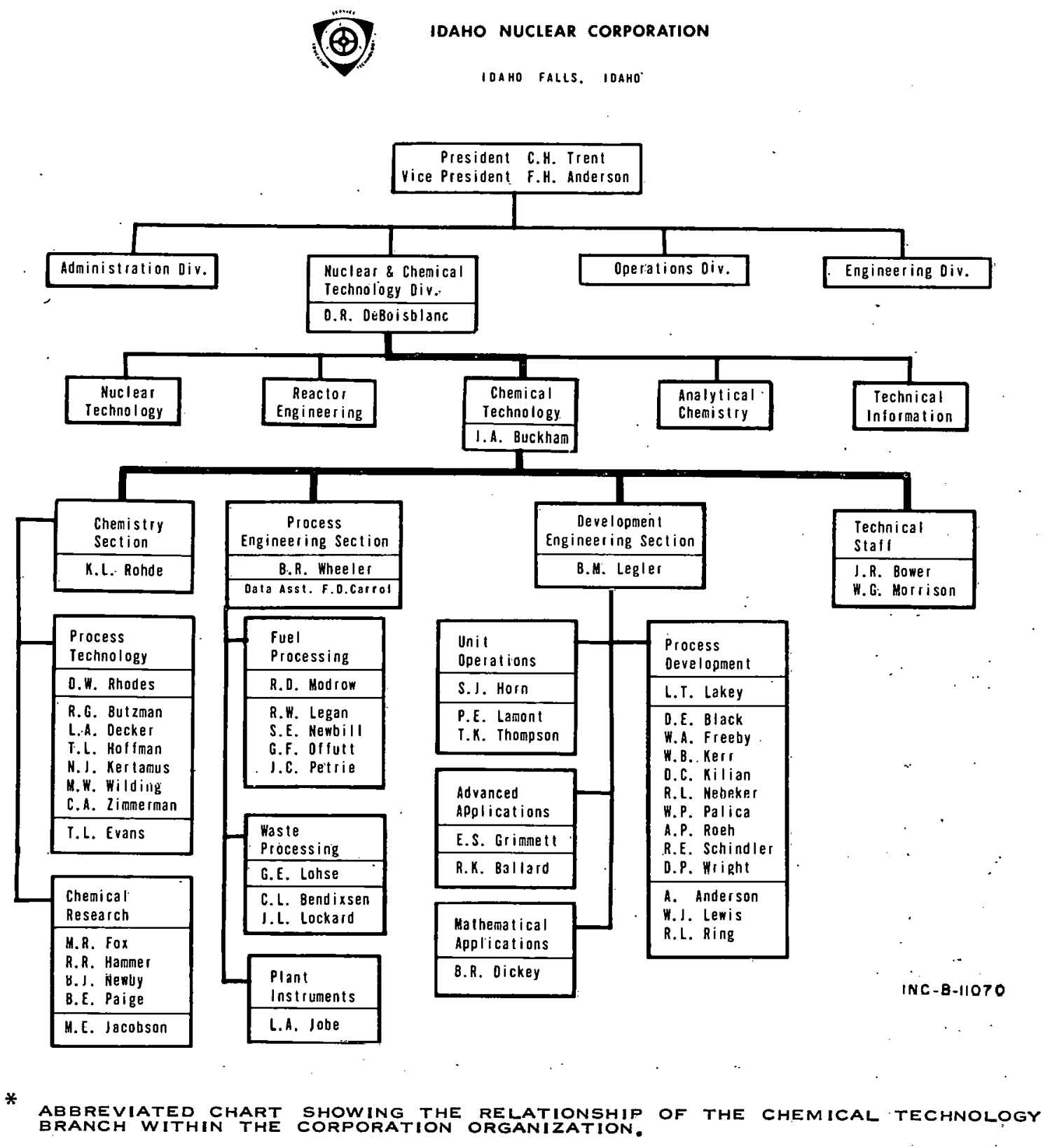




\section{REFERENCES}

1. J. R. Bower (ed.), Chemical and Progress Development Branch Annual Report: Fiscal Year 1966, IDO-14680 (October 1966).

2. M. E. Jacobsen, R. R. Mascarenas, G. F. Offutt, K. L. Rohde, Recovery of Uranium from EBR-I Core 2 Melted Fuel, IN-1088 (May 1967).

3. R. H. Ray, Effect of Recirculation of Dissolver Effluent on the Continuous Dissolution of Aluminum in Mercury-Catalyzed Nitric Acid, IDO-14637 (April 1964).

4. G. F. Offutt et al, First Zirconium Alloyed Fuel Reprocessing Campaign Using Soluble Nuclear Poison, IN-1091 (in preparation)

5. R. D. Fletoher, M. E. Jacobson, H. R. Beard, Effect of Alloying Constitnents on Alumilum Dissolution Kates, IDO-14606 (April 1963).

6. J. ח. Büwer: (ed.), Chemical Processing Technology Quarterly Progress Report, January - March 1964, IDO-14638 (June 1964).

7. J. R. Bower (ed.), Chemical Processing Technology Quarterly Progress Report, October - December 1963, IDO-14635 (March 1964).

8. IDO-18003, Unclassified edition, Idaho Chemical Processing Plant -- Design and Operations Manual for CPM Project, Cells G and H, Blaw Knox Company, (1955)

9. E. C. Pitzer, Electrolytic Dissolution of Stainless Steel Clad Fuel Assemblies, KAPL-653 (December 1951).

10. V. P. Caracciolo and A. A. Kishbaugh, Electrolytic Dissolver for Power Fuels, DP-896 (October 1964).

11. W. B. Kerr, L. T. Lakey, R. G. Denney, Development of a Continuous Electrolytic Process for Recovery of Uranium from High-Enriched Stainless Steel and Nichrome Fuels, IDO-14643 (October 1965).

12. R. G. Butzman and B. J. Newby, Laboratory Feasibility Studies of Aqueous Reprocessing of Zirconium Dioxide-Uranium Fuels, IN-1069 (March 1967).

13. K. L. Rohde (ed.), An Improved Aqueous Process for Zirconium Alloy Nuclear Reactor Fuels: Part I. Preliminary Laboratory Studies, IDO-14594 (October 1962) p 14.

14. T. A. Gens, Processing of Reactor Fuels in Liquid Ammonlum Bifluoride, CF-58-6-36 (June 1958) (Del.).

15. Commissaret A L'Energie Atomique. Centre D'Etudes Nucleaires, FontenayAux-Roses, France, Final Report on the Accident Which Occurred During a Purification of Plutonium on Ion-Exchange Resins June 26, 1962, in the Radiochemical Bullding of CENFAR (CEN-Fontenay-Aux-Roses) July 26,1963, HW-TR-78 (July 1964). (Translated by E. R. Appleby, Hanford Laboratories) 
16. J. R. Bower (ed.), Chemical and Process Development Branch Annual Report: Fiscal Year 1965, IDO-14661 (February 1966).

17. L. T. Lakey, J. R. Bower (eds.), ICPP Waste Calcining Facility Safety Analysis Report, IDO-14620 (December 1963).

18. R. E. Commander, G. E. Lohse, D. E. Black, E. D. Cooper, Operation of the Waste Calcining Facility with Highly Radioactive Aqueous Waste: Report of the First Processing Campaign, IDO-14662 (June 1966).

19. E. S. Grimmett, Particle Growth and Size Distribution in Fluidized Bed Processes - A Mathematical Model with Computer Solutions, IDO-14650 (April 1966).

20. M. W. Wilding and D. W. Rhodes, Stability Studies of Highly Radioactive Alumina Calcine During High Temperature Storage, IDO-14670 (January $\overline{1966) \text {. }}$

21. R. F. Murray and D. W. Rhodes, Low Temperature Polymorphic Transformation of Calcined Alumina, IDO-14581 (September 1962).

22. B. P. Brown, E. S. Grimmett, J. A. Buckham, Development of a Fluidized Bed Calcination Process for Aluminum Nitrate Wastes in a Two-FootSquare Pilot Plant Calciner: Part I. Equipment Development and Initial Process Studies, IDO-14586 (June 1962).

23. J. C. Petrie et al, Fluidized Bed Calcination of Stmulated Zirconium Fluoride Waste in Exploratory P1lot Plant Tests, IDO-14653 (July 1965).

24. H. A. Vreedenberg, "Heat Transfer Between a Fluidized Bed and a Horizontal Tube", Chem. Eng. Scl., $\underline{9}$ (1958) pp 52-60.

25. M. Leva, Fluidization, New York: McGraw-H1ll Book Company, Inc., 1959.

26. J. F. Frantz, "Minimum Fluidization Velocities and Pressure Drop in Fluidization Beds", Chem. Eng. Progr., Symp. Ser., 62 (1966) pp 21-31.

27. S. S. Zabrodsky, Ilydrodynamics and Heat Transfer in Fluidized Beds, Cambridge: Massachusetts Institute of Technology Press, 1966.

28. W. A. Freeby, Heat Transfer Coefficients for Finned Tubes Inside a Fluidized Bed, Thesis, Moscow, University of Idaho, 1966.

29. D. E. Black and B. R. Dickey, Mathematical and Experimental Analysis of Heat Dissipation from Cylindrical Sources Buried in Soll, IN-1032 (December 1966).

30. L. Lapidus, Digital Computation for Chemical Engineers, New York: McGrawHill Book Company, Inc., 1962, pp 254-257.

31. H. Gröber, S. Erk, and U. Grigull, Fundamentals of Heat Transfer, New York: McGraw-Hill Book Company, Inc., 1961. 
32. M. Jakob, Heat Transfer, Volume I, New York: John Wiley and Sons, Inc., 1949.

33. J. C. Petrie, B. R. Dickey, B. M. Legler, Heat Transfer to Vertical, Annular Spaces Open at the Ends, IN-1110 (in preparation).

34. R. R. Hammer, K. L. Rohde, B. J. Newby, The Penetration of Iodine into Protective Coatings, IN-1095 (in preparation).

35. R. C. Shank and Staff, Annual Report of the Analytical Chemistry Branch for 1966, IN-1063 (April 1967).

36. R. L. Coates and N. R. Horton, RSAC -- A Radiological Safety Analysis Computer Program, IDO-17151 (May 1966).

37. W. E. Ranz and J. B. Wong, "Impaction of Dust and Smoke Particles on Surface and Body Collestrnr", Ind. Eng. Chcm., 44 (1952) pp 1371-1381.

38. R. W. Tate and E. O. Olsen, "Spray Droplet Size of Pressure-Atumizing Burner Nozzles", ASHRAE Jour., 4 (March 1962) pp 39-42.

39. G. W. Parker, G. E. Creek, and W. J. Martin, "Fuel Element Decomposition Products", Seventh AEC Air Cleaning Conference, October 10-12, 1961, Held at Brookhaven National Laboratory, Upton, New York, TID-7627 (1961) pp 263-283.

40. R. A. Gussman, C. E. Billings, L. Silverman, “Factors in Condensation Nuclei Counters for Measurement of Aerosol Agglomeration", Seventh AEC Air Cleaning Conference, October 10-12,. 1961, Held at Brookhaven National Laboratory, Upton, New York, TID-7627 (1961) pp 372-389.

41. Argonne National Laboratory, Chemical Engineering Division Semiannial Rcport: Jalluary-June 19154, ANI-6800 (Auguot 1064):

42. A. Glassner, The Thermochemical Properties of the Oxides, Fluorides, and Chlorides to $2500^{\circ} \mathrm{K}$, ANL-5750 (1957).

43. R. R. Hammer, Z1rcaloy-4, Urantum Dioxide, and Materials Formed by their Interaction -- A Literature Review with Extrapolation of Physical Properties to High Temperatures, IN-1093.

44. G. W. Gibson and D. R. deBolsblanc, "Use of Uranium Aluminide Powders in Nuclear Fuel Elements", in Henry H. Hausner (ed.), Proceedings of the International Powder Metallurgy Conference Held in New York, June 14-17, 1965, New York: Plenum Press, 1966. CONF-650631. pp 26-35. 


\section{IN REPORTS}

1. B. E. Palge, Leachability of Alumina Calcine Produced in the Idaho Waste Calcining Faclility, IN-1011 (July 1966).

2. L. A. Decker and R. R. Hammer, A Study of Three Methods for Reprocessing Graphite Fuels: Mixed Acid Oxidation, Grind-Leach, andElectrolytic Disintegration, IN-1018 (January 1967).

3. D. E: Black and B. R. Dickey, Mathematical and Experimental Analysis of Heat Dissipation From Cylindrical Sources Buried in Soll, IN-1032 (December 1966).

4. R. G. Butżman and B. J. Newby, Laboratory Feastbilty Studies of Aqueous Reprocessing of Zirconium Dioxide-Uranium Dioxide. Fuels, IN-1069 (March 1967).

5. M. E. Jacobsen et al, Recovery of Uranium from EBR-I Core 2 Melted Fuel, IN-1088 (May 1967).

6. T. L. Hoffman, Performance of Types 304, 316, and 348 Stainless Steel in NaK at High Temperatures, IN-1089 (May 1967). 


\section{PAPERS PRESENTED AT TECHNICAL SOCIETY MEETINGS}

1. M. W. Wilding and D. W. Rhodes, Stability Studies of Highly Radioactive Alumina Calcine During High Temperature Storage, presented at American Chemical Society meeting in New York, New York (September 1966).

2. R. R. Hammer, B. J. Newby, K. L. Rohde, Penetration of Iodine into Protective Paint Coatings, Presented at American Chemical Society meeting in New York, New York (September 1966).

3. D. E. Black, L. T. Lakey, B. M. Legler, Contamination-Decontamination Experiment at the ICPP, presented at American Chemical Soclety meeting in New York, New York (September 1966).

4. B. M. Legler, Feed Injection for Heated Fluidized Beds, presented at American Institute of Chemical Engineers meeting in Houston, Texas (February 1967),

5. T. L. Hoffman, R. A. Moen, K. C. Sumpter, Corrosion Resistance of Type 316 Stainless Steel in Sodium-Potassinm Eutectic Alloy at $1400^{\circ} \mathrm{F}$, presented at National Assoctation of Corrosion Engineers High Temperature Symposium in Los Angeles, California (March 1967).

6. W. G. Morrison, A Large Dissolver for Irradiated Fuel, presented at Nuclear Criticality Safety National Topical Meeting in Las Vegas, Nevada (December 1966).

7. B. R. Dickey and D. E. Black, Mathematical and Experimental Analysis of Heat Dissipation from Cylindrical Sources Buried in Soll, presented at Idaho Academy of Sclence Meeting in Caldwell, Idaho (May 1967).

8. E. S. Grimmett, R. K. Ballard, J. A. Buckham, A New Process for Uranium Aluminide Manufacture Using Fluidized Bed Techniques, presented at National American Institute of Chemical Engineers meeting in Salt Lake City, Utah (May 1967).

9. B. R. Wheeler, J. A. Buckham, B. R. Dickey, D. E. Black, G. E. Lohse, D. W. Rhodes, The Storage of Radioactive Solids in Underground Facilities, Current ICPP Practices and Future Concepts, presented at IAEA and ENEA Symposium on the Disposal of Radioactive Wastes into the Ground in Vienna, Austrla (May 1967). 


\section{OTHER PUBLICATIONS}

1. L. T. Lakey and W. B. Kerr, "Pilot Plant Development of an Electrolytic Dissolver for Stainless Steel Alloy Nuclear Fuel", I \& EC Proc. Des. \& Develop., 6 (April 1967) pp 174-179.

2. B. J. Newby and K. L. Rohde, "Fission Product Sorption by Protective Coatings", in Oak Ridge National Laboratory, International Symposium on Fission Product Release and Transport Under Accident Conditions, Apr11 5-7, 1965, Oak RIdge, Tennessee, CONF-650407 (1965). pp 720-729.

3. B. M. Legler, "Feed Injection for Heated Fluidized Beds", Chem. Engr. Prog., $\underline{63}$ (February 1967) pp 75-82.

4. T. L. Hoffman, “Stainless Steel Tank for Radioactive Waste Storage”, Mat'ls Prot., 5 (October 1966) pp 13-15. 